\author{
UNIVERSIDADE DE SÃO PAULO \\ FACULDADE DE FILOSOFIA LETRAS E CIÊNCIAS HUMANAS \\ DEPARTAMENTO DE GEOGRAFIA \\ PROGRAMA DE PÓS-GRADUAÇÃO EM GEOGRAFIA HUMANA
}

LUIZ EDUARDO DE FREITAS SANTOS

Trabalho no turismo: faces da precarização de um proletariado contemporâneo e de serviços

v. 1

SÃO PAULO 


\author{
UNIVERSIDADE DE SÃO PAULO \\ FACULDADE DE FILOSOFIA LETRAS E CIÊNCIAS HUMANAS \\ DEPARTAMENTO DE GEOGRAFIA \\ PROGRAMA DE PÓS-GRADUAÇÃO EM GEOGRAFIA HUMANA
}

\title{
Trabalho no turismo: faces da precarização de um proletariado contemporâneo e de serviços
}

Luiz Eduardo de Freitas Santos

Dissertação de Mestrado submetida ao Programa de Pós-Graduação em Geografia Humana da Faculdade de Filosofia Letras e Ciências Humanas da Universidade de São Paulo, para obtenção do título de Mestre em Geografia Humana.

Orientadora: Profa. Dra. Rita de Cássia Ariza da Cruz

v. 1

SÃO PAULO 
Autorizo a reprodução e divulgação total ou parcial deste trabalho, por qualquer meio convencional ou eletrônico, para fins de estudo e pesquisa, desde que citada a fonte.

Catalogação na Publicação

Serviço de Biblioteca e Documentação

Faculdade de Filosofia, Letras e Ciências Humanas da Universidade de São Paulo

S231t

Santos, Luiz Eduardo de Freitas

Trabalho no turismo: faces da precarização de um proletariado contemporâneo e de serviços / Luiz Eduardo de Freitas Santos ; orientadora Rita de Cássia Ariza da Cruz. - São Paulo, 2018.

$189 \mathrm{f}$.

Dissertação (Mestrado) - Faculdade de Filosofia, Letras e Ciências Humanas da Universidade de São Paulo. Departamento de Geografia. Área de concentração: Geografia Humana.

1. trabalho, . 2. trabalho no turismo, . 3. emprego. 4. informalidade. 5. precarização. I. Cruz, Rita de Cássia Ariza da, orient. II. Título. 

Agradeço a Deus, à minha família e amigos, aos colegas e professores da pós-graduação e em especial à professora Rita Cruz, que sempre acreditou no potencial deste projeto. 
Emprestemos das ciências e das artes as possibilidades para interpretar o mundo! 
"And money is like muck, not good except it be spread" "E dinheiro é como esterco, não cheira bem, exceto se espalhar"

Francis Bacon, Essays, of sedictions and troubles (1597, tradução nossa).

[...] "E um fato novo se viu Que a todos admirava: O que o operário dizia Outro operário escutava.

E foi assim que o operário Do edifício em construção Que sempre dizia sim Começou a dizer não. E aprendeu a notar coisas A que não dava atenção:

Notou que sua marmita Era o prato do patrão Que sua cerveja preta Era o uísque do patrão Que seu macacão de zuarte

Era o terno do patrão Que o casebre onde morava Era a mansão do patrão Que seus dois pés andarilhos

Eram as rodas do patrão Que a dureza do seu dia

Era a noite do patrão Que sua imensa fadiga Era amiga do patrão" [...]

Vinícius de Moraes, O operário em construção (1959). 


\title{
Resumo:
}

De acordo com o discurso oficial presente nas agências de fomento à atividade, nos órgãos governamentais e na grande mídia, o turismo é um setor responsável pela criação de grande quantidade de postos de trabalho e geração de renda para o país. No entanto, em outra vertente de análise, quando identificamos a real quantidade de postos de trabalho criados e a qualidade dos mesmos percebemos que o discurso parece não se refletir na prática. Visando investigar a presente situação este estudo tem por objetivo identificar as principais características do trabalho no turismo no Brasil. Para tanto, realizamos um trabalho de pesquisa para levantar o total do pessoal ocupado, a distribuição geográfica, além de aspectos demográficos e ocupacionais do trabalho no setor, onde identificamos sinais de forte informalidade, baixos salários, extensas jornadas, baixa qualificação e precarização. Este levantamento mais acurado permite um melhor entendimento do emprego no setor, bem como importantes aspectos da organização do próprio turismo no país.

Palavras chave: trabalho, trabalho no turismo, emprego, informalidade, precarização.

\begin{abstract}
:
According to the official speech, present in the activity promotion agencies, in government agencies and in the mainstream media, tourism is an industry responsible for creating a large number of jobs and generating income for the country. However, in another aspect of analysis, when we identify the real number of jobs created and the quality of the same, we realize that the speech does not seem to be reflected in practice. Aiming to investigate the present situation, this study aims to identify the main characteristics of labour in tourism in Brazil. To do so, we carried out a survey to collect the total number of employees, geographical distribution, demographic and occupational aspects of the labour in the sector, identifying signs of strong informality, low salaries, long hours, low qualification and precariousness. This more accurate survey, however, will allow a better understanding of labour and employment in the sector, as well as aspects of the organization of tourism itself in the country.
\end{abstract}

Key words: labour, labour in tourism, employment, informality, precariousness. 


\section{Sumário:}

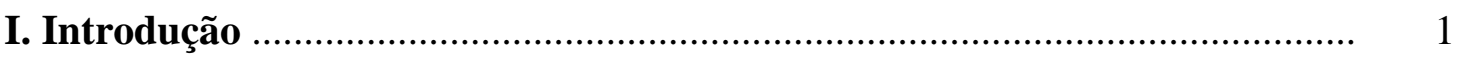

I.1 Definindo caminhos .............................................................................

I.2 O problema de pesquisa ………………………………………………...

I.3 Hipótese de trabalho .................................................................................

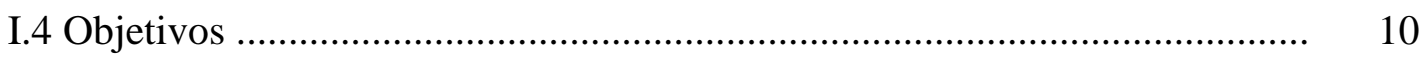

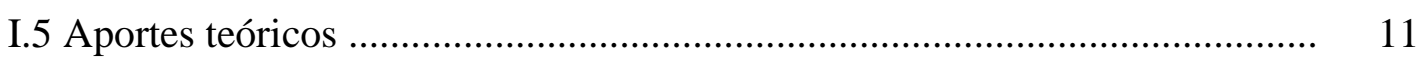

I.6 Procedimentos metodológicos ...................................................................... 13

\section{Capítulo 1 As transformações do trabalho e do mundo do trabalho}

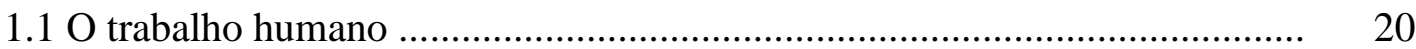

$1.2 \mathrm{O}$ trabalho humano e suas diferentes possibilidades de análise ................... 23

$1.3 \mathrm{O}$ trabalho no mundo capitalista: da teoria do valor-trabalho à sociedade do trabalho

1.4 O conhecimento como valor: a Era Pós-industrial e a crise da sociedade do trabalho

1.5 A perda de referencial do trabalho como norteador da vida ........................ 50

$1.6 \mathrm{O}$ trabalho hoje: a precarização como saída para a crise do capital .............. 57

\section{Capítulo 20 trabalho no turismo: da genealogia das práticas à criação de} um novo mercado de trabalho

2.1 A gênese dos territórios turísticos ……………………………………….... 67

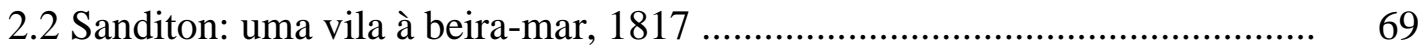

2.3 Ilha de Guernsey, 1866 ...................................................................... 76

2.4 As origens do trabalho no turismo no Brasil ............................................. 80

2.5 A ilha de Guernsey hoje e os 'novos' trabalhadores do mar ......................... 89

\section{Capítulo 3 A força de trabalho no turismo}

$3.1 \mathrm{O}$ trabalho no turismo ............................................................................ 92

3.2 $\mathrm{O}$ trabalho no turismo sob a perspectiva da OMT ……………………….... 95

$3.3 \mathrm{O}$ trabalho no turismo no Brasil ............................................................... 101

3.3.1 A evolução recente dos estudos sobre o trabalho no turismo no Brasil .... 101

3.3.2 A parceria MTur/IPEA e o Sistema de Informações sobre o mercado de trabalho no turismo - SIMT 
3.4.1. Distribuição espacial do trabalho no turismo .......................................... 122

3.4.2 Aspectos ocupacionais ........................................................................ 146

3.5 O trabalho no turismo sob uma perspectiva crítica ..................................... 160

II. Considerações Finais .......................................................................... 166

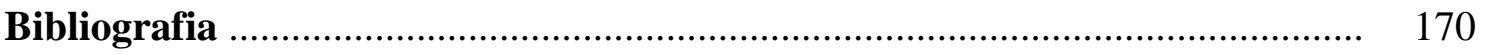

\section{Índice de mapas, tabelas e quadros}

Mapa 1. Brasil 2010: número de empregos no turismo por estados 125

Mapa 2. Brasil 2006: proporção de trabalho formal e informal por estado 129

Mapa 3. Brasil 2008: ACT Alojamento - emprego formal 135

Mapa 4. Brasil 2008: ACT Agências de Viagem - emprego formal 137

Mapa 5. Brasil 2014: Agências de Turismo por Unidades da Federação 138

Mapa 6. Brasil 2008: ACT Alimentação - emprego formal 139

Mapa 7. Brasil 2010: taxa de dependência do turismo baseada em número de 143

estabelecimentos por UF (em \%)

Mapa 8. Brasil 2010: taxa de dependência do turismo baseada no número de empregos por UF (em \%)

Tabela 1. Crescimento da mão-de-obra no turismo: 2002 - 2013 (em milhões) 123

Tabela 2. Trabalho no turismo: distribuição percentual por regiões (2011) 126

Tabela 3. Trabalho formal e informal nas ACTs: 2002 - 2006 (em mil) 131

Tabela 4. Alteração na composição das ACTs: 2008/2015 132

Tabela 5. Brasil 2011: participação relativa das ACTs no setor turismo 133

Tabela 6. Brasil 2006 - 2010: índice de dependência do turismo (em \%) 142

Tabela 7. Salário no turismo x Salário no total da economia (2006 - 2013) 148

Tabela 8. Brasil e Regiões 2011: remuneração média do empregado formal do 148 turismo por ACT (em R $\$$ )

Tabela 9. Comparação da remuneração média: Nordeste x Economia - 2011 (em 150 $\mathrm{R} \$)$

Tabela 10. Turismo: remuneração média por regiões - 2011 
Tabela 11. Trabalho no turismo: rotatividade por ACT (2002 - 2006)

Tabela 12. Rotatividade no Turismo: proporção de empregos com menos de 12 meses

Tabela 13. Trabalho no turismo: Contrato de trabalho x Pessoal empregado (2002 - 2006)

Tabela 14. Remuneração Média (S.M) / Tamanho dos estabelecimentos (2002 2006)

Tabela 15. Tamanho dos estabelecimentos por número de empregados nas ACTs (2002-2006)

Tabela 16. Percentual de trabalhadores em estabelecimentos com 10 a 99 empregados

Tabela 17. Grau de instrução: trabalhadores no turismo x CLT

Tabela 18. Educação formal x ACTs (2002 - 2006) 



\section{Introdução}

Nos últimos anos, vem sendo frequente a associação da imagem do turismo como uma importante atividade para a geração de emprego e renda.

Quanto a isso, é crescente a quantidade de discursos e materiais de divulgação, que procuram associar o turismo ao emprego e à renda. Como um dos muitos exemplos selecionamos uma pequena parte do discurso de Taleb Rifai, Secretário Geral da Organização Mundial do Turismo - OMT, pelo período de 2010 a 2017.

\footnotetext{
“O progresso e a expansão contínua do turismo representam uma solução eficaz para muitos dos maiores desafios do mundo. De fato, poucos setores estão tão estrategicamente posicionados quanto o turismo para contribuir decisivamente para a criação de empregos, redução da pobreza, proteção ambiental e paz e compreensão multicultural" ${ }^{\prime 1}$ (OMT, 2015, p.2).
}

Muito além do discurso oficial da OMT, diversos órgãos oficiais, agências especializadas na promoção do turismo, bem como a grande mídia têm produzido farto material sobre o assunto.

Por meio de alguns exemplos podemos perceber que estamos diante de um fenômeno mundial, com a presença de grandes organismos internacionais, que com o apoio e suporte de organizações nacionais e locais ocupam-se em destacar a geração de postos de trabalho no turismo como um dos pontos fortes do setor.

Quanto a esse assunto, podemos citar a própria Organização Mundial do Turismo (OMT), que em seu website ${ }^{2}$ oficial apresentou dados sobre o trabalho no turismo apontando que o setor é responsável por 1 em cada 10 empregos gerados em todo mundo. A base dos dados, no entanto, é a World Travel \& Tourism Council - WTTC, uma entidade fundada em 1991 por um grupo de empresários do setor, com interesses muito evidentes.

1. "Tourism's continued progress and expansion represents an effective solution for many of the world's greatest challenges. Indeed, few sectors are as strategically positioned as tourism to contribute decisively to job creation, poverty alleviation, environmental protection and multicultural peace and understanding" (UNWTO Annual Report 2014, 2015, p.2).

2. Fonte: 〈http://www2.unwto.org/> Acesso em: 06/05/2018. 
A esse respeito, cabe também a leitura do Plano Nacional do Turismo do Ministério do Turismo: mais emprego e renda para o Brasil, elaborado em 2015 pelo Governo Federal, e que tem no próprio subtítulo a menção à geração de mais emprego para o país. Pela leitura do texto podemos identificar, que uma das metas do plano é a geração de dois milhões de empregos no período, ampliando, de sete, para 9 milhões, o número de empregos no turismo, no país. No entanto, o que o plano não deixa claro é a base utilizada para contabilizar os sete milhões de empregos atuais, já que números do $\operatorname{IPEA}^{3}$ dão conta de uma quantidade muito menos expressiva de postos de trabalho.

Neste contexto global, embora muitos agentes indutores do turismo se empenhem em desenvolver farto arsenal de materiais ${ }^{4}$ com esse objetivo, o assunto vem sendo pouco discutido, principalmente no que tange à qualidade e as características dos postos de trabalho criados.

Uma leitura mais acurada da situação, no entanto, parece revelar algumas fragilidades do discurso vigente, pois a dificuldade em encontrar fontes confiáveis inibe a possibilidade de estabelecer números consistentes ou mesmo de discutir as características do tipo de trabalho gerado.

A tentativa de unir a imagem do turismo à geração de emprego, além de carecer de uma maior sustentação teórica, parece também um tanto quanto controversa, principalmente quando se discute o trabalho no mundo atual, suas transformações e a crise da chamada Sociedade do Trabalho.

Com isso posto, parece estarmos perante de um paradoxo. Talvez estejamos diante de uma grande descoberta e encontrado uma saída mágica a uma importante crise, pois se o emprego está fadado a sumir no mundo todo, o turismo surge como a grande solução para este problema.

Ou talvez estejamos diante de algo diferente, um grande engodo, quem sabe?

3. "Em dezembro de 2011, as Atividades Características do Turismo - ACTs eram responsáveis por aproximadamente 2,077 milhões de ocupações no Brasil. Entre estas, cerca de 947 mil (47\%) eram empregos formais e 1.131, informais (53\% do total)" (IPEA, 2014, p.13).

4. A campanha Descubra o Brasil, é uma campanha publicitária da Rede Globo e seu site de notícias, o G1, em parceria com o Ministério do Turismo, que apresenta o país e suas regiões, como roteiros turísticos, por meio de uma variada gama de vídeos publicitários. A cada vídeo o slogam publicitário: "Mais emprego e renda para o país" é novamente reproduzido. Fonte: 〈http://g1.globo.com/turismo-e-viagem/〉 Acesso em: 05/05/2018 
E é sob essa indagação que esta dissertação se inicia e se desenrola. Quando estudamos mais detidamente o assunto podemos identificar a construção de um discurso político que, conjugado aos interesses econômicos em curso transforma-se em propaganda ideológica, conferindo ao turismo uma sobrevalorizada capacidade de geração de emprego e renda.

Considerando tais evidências, parece haver, portanto, interesses implícitos quanto a isso, haja vista que ninguém, em senso comum, seria contrário a uma atividade capaz de gerar emprego e renda, principalmente em uma época onde a escassez de ambos se apresenta de maneira tão nítida.

E assim, sob esse grande pano de fundo, esta pesquisa tem como objeto central explorar as características e especificidades do trabalho no turismo, diante de um emaranhado de informações que nem sempre cumprem sua função de forma eficaz.

Esperamos também contribuir com as discussões sobre o trabalho na sociedade atual (com suas crises e transformações), com as pesquisas sobre o Turismo em seus aspectos estruturais, bem como com os estudos sobre a Geografia do Trabalho. 


\section{I.1 Definindo caminhos}

Este estudo é fruto de um esforço de pesquisa que vem sendo realizado, ao longo dos quatro últimos anos, desde o preparo para o ingresso no processo seletivo para o programa de pós-graduação em Geografia Humana da Faculdade de Filosofia da Universidade de São Paulo, ainda em 2014.

No ano seguinte, em julho de 2015, com a devida aprovação e consequente ingresso ao programa citado, o objeto de pesquisa foi sendo definido e ganhando o contorno atual, que por ora apresentamos.

Um dos pontos de partida para sua estruturação é a importância do trabalho bem como suas características e estruturação para a sociedade atual, suas crises e transformações recentes.

Tal problemática, por si, não é recente e seu estudo percorre a própria história da humanidade, convergindo com os conceitos apresentados por Ruy Moreira, segundo o qual, "o trabalho é a fonte de origem de toda sociedade e, em cada sociedade, segundo o caráter do modo de produção que a organiza desde a base, o trabalho aparece, sob formas de relação que historicamente lhe são próprias" (MOREIRA, 2016, p. 53).

Por meio desta rápida problematização podemos compreender que o trabalho humano sempre representou uma especial função como elemento estruturante das sociedades e transformador do espaço geográfico.

Com esta perspectiva, nossos esforços de pesquisa sempre nos conduziram para a realização de um estudo, que pode ser caracterizado como inserido no subcampo da Geografia do Trabalho, para a qual pretendemos trazer contribuições, pois como diria Ruy Moreira, "o trabalho é um tema historicamente recorrente na Geografia. Todavia, tem sido total a ausência de uma explicação conceitual e analítica desse tema entre os geógrafos". Ou seja, [...] "o trabalho é um processo cuja leitura espacial está ainda por se teorizar" (MOREIRA, 2016, p. 201).

Mesmo diante de indefinições teóricas, o tema 'trabalho na contemporaneidade' nos traz um grande desejo de entendimento. Entendimento este que se faz urgente e necessário diante do turbilhão de transformações presentes no chamado mundo do trabalho. 
No momento presente vemos uma transformação nos conceitos sobre o trabalho, tal como aponta André Gorz, em seu livro "Metamorfoses do Trabalho", que enfatiza que o que chamamos de 'trabalho' é uma invenção da modernidade. “A forma sob a qual conhecemos e praticamos aquilo que é o cerne de nossa existência, individual e social, foi uma invenção, conhecida por industrialismo" (GORZ, 2007, p.21).

O industrialismo, surgido da Revolução Industrial, viveu seu período de apogeu e revela agora seus sinais de crise.

A esse respeito, Hannah Arendt, em um de seus trabalhos mais expressivos destaca que: [...] "A sociedade que está para ser liberada dos grilhões do trabalho é uma sociedade de trabalhadores. [...] O que se nos depara, portanto, é a possibilidade de uma sociedade de trabalhadores sem trabalho, isto é, sem dúvida a única atividade que lhes resta. Certamente nada poderia ser pior" (ARENDT, 1958, p. 13).

No avançar das décadas, autores como Toffler (1980) descrevem uma civilização industrial moribunda, enquanto Masuda (1980) acrescenta que a humanidade está vivendo um período de transformação de uma sociedade industrial para uma sociedade da informação.

Numa outra vertente de análise, entre tantos autores que se debatem sobre "os sentidos do trabalho", Ricardo Antunes se propõe a discutir as questões relativas ao trabalho na transição entre os séculos XX e XXI, bem como as transformações e centralidades do trabalho nos dias atuais, repensando a classe trabalhadora hoje. Para o autor, uma noção ampliada é fundamental para a compreensão do proletariado moderno, que inclui, além do proletariado industrial e rural, os assalariados do setor de serviços, aqueles inseridos nos bancos, no comércio, nos serviços públicos, no turismo, etc., que constituem um segmento em expansão no capitalismo contemporâneo (ANTUNES, 1999, pp. 102-103).

E é diante deste mundo do trabalho em transformação, que foi surgindo a proposta deste estudo.

Diante das transformações do trabalho na contemporaneidade, um dos fenômenos emergentes, embora pouco estudado, vem a ser o trabalho no turismo.

Tal tema apresenta-se como um importante campo de investigação científica em razão do fato de que se trata de um fenômeno complexo, pouco estudado, relativamente recente e em expansão em todo o mundo. 
Para a própria Organização Mundial do Turismo - OMT (2014), os dados relacionados ao trabalho e ao emprego no turismo ainda são fragmentados, e não têm qualidade e comparabilidade internacional. O turismo envolve uma ampla variedade de diferentes atividades, tipos de estabelecimentos, contratos e acordos de trabalho, além de que o padrão de trabalho é caracterizado por notável diferença entre regiões de um país e entre estações do ano.

Os fatos e as conclusões apresentados pelos estudos da OMT só confirmam que o mundo do trabalho no setor do turismo, em geral, e o valor econômico do turismo em termos de emprego, como fonte de trabalho produtivo em particular, permanecem inadequadamente medidos e insuficientemente estudados.

De acordo com Cruz, "outra parte importante das dificuldades daqueles que se dedicam a pesquisar o fenômeno do turismo de um modo geral e a sua dimensão espacial, especificamente, é fruto inquestionável, das ambiguidades a ele imanentes, a começar por sua própria natureza, ao mesmo tempo prática social e atividade econômica” [...] (CRUZ, 2007, p. 4).

Pelo exposto, entendemos que a escolha do tema parece-nos oportuna, muito embora a insuficiência de estudos e definições sobre a própria Geografia do Trabalho e ao trabalho no turismo pudessem acarretar dificuldades teóricas e metodológicas.

Por tudo isso, ao longo de todo o período da pesquisa, pudemos perceber que, tanto a Geografia do Trabalho, quanto o trabalho no Turismo exigiriam esforços de superação na tratativa dos dados, visando à construção de um projeto de pesquisa que fosse coerente, pertinente e operacional.

Os resultados aqui apresentados, no entanto, permitem uma análise das características do emprego e da força de trabalho no turismo, os quais esperamos contribuir para os futuros estudos sobre a Geografia do Trabalho e do Turismo como um todo. 


\section{I.2 O problema de pesquisa}

Para a socióloga Nise Jinkings (2000), “as transformações em curso na sociedade capitalista são interpretadas, por diversos autores, como expressão de uma crise estrutural do capital e dos mecanismos engendrados na tentativa de sua superação". Nesse sentido, Ricardo Antunes reforça que, "é para enfrentar essa crise que se desencadeia, desde o final dos anos 70, um processo de reorganização do capital e de seu sistema de dominação de classe, [...] movimentos intensivos de reestruturação dos ambientes produtivos" (JINKINGS, 2000, pp. 97-98).

Diante dessa crise estrutural, a sociedade do trabalho, que surge como um marco entre as sociedades capitalistas vive totalmente à mercê das crises do próprio capital e, por consequência, das crises do trabalho e suas novas morfologias. Conforme nos aponta Ruy Moreira, nos dias atuais a centralidade da fábrica dá lugar às outras formas de trabalho. $\mathrm{O}$ operariado fabril vem dando lugar ao operariado do comércio e dos serviços (MOREIRA, 2016).

A esse respeito, Hannah Arendt (1958:1987), no prólogo de seu livro “A condição humana" nos dá sinais de uma de suas maiores preocupações: "o advento da automação, que já se fazia realidade àquela época, prometia que, nas décadas vindouras, esvaziaria as fábricas e libertaria a humanidade de seu fardo mais antigo e mais natural: o fardo do trabalho e a sujeição à necessidade". A preocupação da autora, no entanto, vai além da aparência e do discurso. Para Arendt, a era moderna trouxe consigo a glorificação teórica do trabalho, e resultou na transformação efetiva de toda sociedade em uma sociedade operária.

O contexto exposto pelos autores apresentados até aqui evidencia a perda de importância relativa da fábrica e do operariado fabril e a emergência de novas formas de trabalho no comércio e em serviços, onde o turismo, enquanto atividade econômica vem sendo apontado como uma possibilidade para a geração de emprego e renda, em substituição aos postos de trabalho na indústria.

No entanto, estudos preliminares apontam que o emprego no turismo é, em geral, de baixa escolaridade, exige pouca qualificação e oferece baixa remuneração, dando mostras de que o turismo oferece oportunidades que acentuam as desigualdades regionais, sociais e de gênero. Fatores como a sazonalidade, precariedade, alta rotatividade, entre outros, dificultam 
a qualificação da mão de obra e comprometem serviços oferecidos, tornando-se desafios para o setor.

Os poucos estudos realizados sobre o tema, não permitem uma análise melhor qualificada quanto ao potencial de geração de empregos e renda do setor, pois, conforme sinaliza Cruz,

[...] a geração de empregos diretos e indiretos nas localidades receptoras não deve ser fator demasiadamente valorizado como impacto positivo do turismo, mesmo porque não existem estudos aprofundados sobre esse tema. Conforme coloca Hiernaux (1988), no caso de Cancun, muitos mexicanos hoje empregados em atividades relacionadas ao turismo abandonaram seu trabalho na zona rural, havendo nesse caso, portanto, uma realocação de mão de obra, com impacto negativo sobre a agricultura dos arredores do referido complexo turístico (CRUZ, 2003, p.114).

Neste momento parece estarmos diante de um importante ponto de inflexão, de uma mudança de padrão, no que se refere ao trabalho, ou ao mundo do trabalho. Muitos autores apontam para o fim do industrialismo e o início da era da informação e dos serviços. Outros preferem apontar seus estudos para o fim do próprio trabalho, enquanto outros apontam para o crescimento de sua precarização.

Entre uns e outros, ainda há aqueles que insistem em apontar saídas mágicas para a crise anunciada. Entre estes residem àqueles apoteóticos do turismo como fator gerador de emprego e renda, capazes, portanto, de reverter os sinais da crise e reestabelecer o rumo 'natural' das coisas. 


\section{I.3 Hipótese de trabalho}

Embora o discurso corrente aponte para um enorme potencial do turismo enquanto gerador de emprego e renda, nos mais distantes rincões do país, acreditamos que, na realidade, as possibilidades não se mostram tão otimistas.

Estudos melhor fundamentados sobre o trabalho no turismo, como os realizados pelo Instituto de Pesquisa Econômica Aplicada - IPEA, em parceria com o Ministério do Turismo - MTur, apontam que a capacidade de geração de emprego por parte do turismo é mais modesta do que supõe o discurso oficial, a grande mídia e as agências de fomento à atividade.

O que se observa na prática é que o emprego no turismo cresce quando a economia como um todo está aquecida. Ou seja, o emprego no turismo cresce quando a economia cresce, e não o contrário. Isto ocorre porque o desenvolvimento econômico promove renda, que acaba por impulsionar o turismo.

Um bom exemplo desta situação pode ser observado na Região Sudeste, que concentra 43\% dos capitais da economia nacional, e concentra mais de 50\% dos trabalhadores formais no turismo (IPEA, 2014, p. 14).

Embora o potencial de geração de emprego e renda do turismo exista, o mesmo não se dá de forma igual e com o mesmo dinamismo em todas as regiões do país. Ao contrário, ao analisar diversos componentes do trabalho como salário, escolaridade e tempo no trabalho podemos observar que os melhores índices recaem sobre as regiões mais ricas do país. Isto demonstra, ainda de forma não conclusiva, que o trabalho no turismo, dependendo do arranjo de outros aspectos socioeconômicos de cada região, pode acirrar as diferenças locais, regionais, sociais e de gênero, contribuindo de forma modesta e parcial para a geração de postos de trabalho no contexto da economia nacional. 


\section{I.4 Objetivos}

Diante dos aspectos ressaltados acima, o objetivo geral norteador de nossa pesquisa foi identificar, elencar, descrever e analisar as principais características do trabalho no turismo no Brasil. Entre as principais características do trabalho listamos:

I - Distribuição espacial da força de trabalho: pessoal ocupado - no país, regiões e estados; as Atividades Características do Turismo - ACTs e o; Índice de Dependência do Turismo.

II - Aspectos ocupacionais: faixas salariais; tempo no emprego (rotatividade); jornada de trabalho (horas semanais); tamanho dos estabelecimentos e; nível de escolaridade.

Os dados pesquisados permitiram a identificação da distribuição geográfica das características do emprego no turismo, tanto na escala nacional, quanto nas escalas regionais e estaduais, contribuindo para uma abordagem geográfica do tema.

A partir da identificação das características do trabalho no turismo, bem como da distribuição geográfica do mesmo pretendemos discutir as afirmações do discurso oficial e de diferentes entidades de fomento do setor, propondo uma visão mais realista sobre o tema. 


\section{I.5 Aportes teóricos}

Para a composição desta dissertação foram consideradas contribuições teóricas de diferentes autores em diferentes campos de estudo, destacando-se a análise crítica de autores internacionais como Britton (1991), Cañada (2017), Shaw e William (1994). No Brasil, a esse respeito, adotamos a análise de Cruz (2003, 2007 e 2018), que enfatiza a crítica e reforça a escassez de estudos sobre o tema.

Sobre o trabalho e sua crise na sociedade atual, nossos referenciais teóricos baseiam-se nos trabalhos de Hannah Arendt (1958:1987) e Andre Gorz (2007), que centram suas análises nas transformações do trabalho, desde a antiguidade clássica, até a era moderna. Quanto às transformações mais recentes, autores como Toffler (1980), Masuda (1980), Naisbitt (1983) e Drucker (1993) ressaltam a passagem da Era Industrial para a Era da Informação.

Com a profunda transformação no mundo do trabalho ocorre a crise da Sociedade do Trabalho, presente nas formulações teóricas de Ruy Moreira (2016) e do próprio Andre Gorz (2007)

Diante deste contexto de transformações, que marcam o fim do chamado industrialismo, teóricos como Offe (1989) acentuam suas análises na perda de importância do trabalho como norteador da vida em sociedade, enquanto que para Antunes (1999), num sentido contrário, as transformações em curso marcam o aumento da precarização das relações de trabalho e o crescimento de um novo proletariado, que irá incluir, além dos trabalhadores das fábricas e do campo, os trabalhadores em serviços, entre eles os trabalhadores do turismo.

E é nesse novo contexto de profundas transformações do trabalho em todo o mundo, que o trabalho no turismo vem sendo trazido à tona como uma solução para a crise do trabalho e do emprego.

Para aprofundar a análise em nosso objeto de pesquisa adotamos os estudos do Instituto de Pesquisa Econômica Aplicada - IPEA, acerca do Trabalho no Turismo, realizados no período entre 2003 a 2015 e que permitem farta análise sobre as características do trabalho e emprego no turismo no país. 
Ao término da análise deste material e adotando os referenciais teóricos aqui descritos poderemos analisar, com maior discernimento, a real dimensão do trabalho no turismo no Brasil. 


\section{I.6 Procedimentos metodológicos}

De acordo com Isabella Perrota "a modernidade é o berço do turismo" (PERROTA, 2011, p.159).

É, portanto, no estudo do período moderno, que iremos identificar a gênese do nosso objeto de estudo, o trabalho no turismo, que surge, obviamente, com o início do próprio turismo, tanto como prática social, quanto atividade econômica.

Para tanto, damos início à nossa pesquisa, buscando identificar a gênese desta atividade.

Para centrar nossos esforços na identificação da gênese do turismo e do trabalho no turismo enveredamos nossas análises iniciais na literatura do século XIX, destacando dois autores europeus e dois autores nacionais.

Da literatura internacional citamos a inglesa Jane Austen (1775-1817) e o francês Victor Hugo (1802-1885) e entre os autores nacionais destacamos Arthur de Azevedo (18551908) e as memórias de Maria Paes de Barros (1851-1952).

Em Jane Austin, encontramos em seu último trabalho, a novela inacabada Sanditon, de 1817, um exemplar raro e, talvez, uma das primeiras críticas sociais, bem ao estilo da autora, crítica mordaz da sociedade burguesa da época, que, imitando os costumes da nobreza, passa a frequentar as estações balneárias à beira-mar.

Nesta novela inacabada, devido à morte prematura da autora, encontramos uma rica descrição das transformações físicas e sociais de uma localidade imaginária, com a finalidade de transformar-se em destino turístico. A rica proprietária do lugar, associada a um jovem e ambicioso empreendedor imobiliário encontram-se às voltas com todos os tipos de vigarices para atrair turistas, especular com as propriedades e controlar a mão-de-obra, a fim de angariar todo o lucro possível.

É em Sanditon, conforme aponta Alain Corbin, que "pela primeira vez, a sociabilidade organizada em torno do banho de mar torna-se o objeto central de uma obra romanesca" (CORBAIN, 1989, p.297).

Ali, embora o foco da narrativa seja a crítica à sociedade burguesa da Inglaterra, no período inicial da Era Industrial identifica-se a presença de trabalhadores ligados ao turismo. Pessoas simples: cocheiros, jardineiros, pastores, pescadores, empregadas domésticas e até as auxiliares de banho, que começam a fazer parte de um conjunto de trabalhadores ligados à atividade turística, que residiriam periféricos por séculos, à sombra do emprego industrial, então fortemente determinante para a economia da época. 
Alguns anos depois da obra de Jane Austin, vamos encontrar na obra-prima de Victor Hugo, "Os trabalhadores do mar", novos fragmentos das origens do trabalho no turismo.

Em "Os trabalhadores do mar" (1866), Victor Hugo retrata a pequena ilha de Guernsey e seus homens simples, pescadores, marinheiros, camponeses em constante luta pela sobrevivência e contra os desígnios da natureza. O trabalho contínuo dos camponeses, pastores, pescadores, quebradores de pedra, comerciantes, marinheiros, entre outros.

Durante a narrativa o autor confronta as tradições do lugar com as transformações da modernidade. $\mathrm{O}$ barco a vapor, as novas relações de trabalho, as novas relações capitalistas, e a chegada do turismo, ainda que incipiente.

Nada escapa à visão astuta do autor, que parecia antever o expoente destino turístico do lugar, que seria transformado por completo, um século depois. Uma pacata ilha no Canal da Mancha, que se transformaria em um dos destinos turísticos mais procurados da região.

No Brasil a literatura nos brinda com bons exemplos de situações que descrevem um novo tipo de trabalho, que surge juntamente com uma nova atividade econômica e que emerge em uma sociedade à busca de romper com seu passado colonial e conectar-se com um novo modo de vida. Um novo modo de vida que já emitia seus sinais desde a Europa, repercutindo fortemente no país.

Neste estudo utilizamos um fragmento do trabalho do dramaturgo brasileiro Arthur de Azevedo, que traz ao público, na então cidade do Rio de Janeiro, a peça "A Capital Federal”, em 1897.

Trata-se de uma comédia de costumes, gênero literário fortemente presente na vida cultural do Rio de Janeiro na época, com forte inspiração dos teatros de Paris. A peça promovia uma visão cômica e crítica da sociedade carioca, envolvida em cenas pitorescas, que se passam, em grande parte, no Grande Hotel Nacional, com seus hóspedes exigentes e suas criadas e criados estafados pelo insessante movimento daquele grande empreendimento.

A comédia procura retratar de forma jocosa aspectos satíricos da sociedade carioca da época, alternando comédia e crítica aos problemas urbanos crescentes.

Segundo João Roberto Farias (2016) o Grande Hotel Nacional representa, "o cosmopolitismo da cidade do Rio de Janeiro, a todo o momento comparado a Paris, onde, para o autor, de forma irônica, "não há hotéis melhores do que o Grande Hotel da Capital Federal." Ainda Segundo Farias [...] "a construção do hotel é efeito do progresso. Metonimicamente, o hotel representa a cidade que se moderniza, para o bem e para o mal, como a peça nos mostrará” (FARIAS, 2016, p. 160). 
Outro exemplo que trazemos da literatura, difere do anterior. Saímos do teatro satírico e vamos às memórias da Paulicéia "No Tempo de Dantes" (1998), descrita a partir da vida de Maria Paes de Barros, representante da elite paulistana, na transição entre os séculos XIX e XX. De sua infância e juventude, a autora retrata os hábitos de uma elite abastada, que recorre às viagens por puro recreio, a Santos, para a "deliciosa perspectiva dos banhos de mar". Novos hábitos de uma elite paulistana, que procurava reproduzir os padrões da elite europeia, já retratados por Jane Austin e Victor Hugo, além de satirizado por Arthur de Azevedo.

Paes de Barros relata a longa viagem de dois dias à terra de Martim Afonso de Souza, realizada com grande número de escravos, mucamas e pajens, além dos tocadores de banguês (PAES DE BARROS, 1998, p. 60).

Como se vê, no Brasil há um período de transição que conjuga os hábitos modernos de uma elite nacional, que adotou o turismo como um leque de práticas, que visam o lazer, a saúde e os bons hábitos, todos eles importados da Europa, com uma sociedade oligárquica e escravocrata, com grande número de pajens e mucamas, onde o moderno e o colonial se misturam.

A análise da literatura do século XIX permite identificar a origem de um tipo novo de trabalho, atrelado à atividade do turismo, a qual, porém, reside periférica ao trabalho industrial, conforme iremos retratar no capítulo 3.

Ao longo do capítulo 1, nosso trabalho consiste na análise teórica de diferentes pensadores que realizaram leituras sobre o trabalho em diferentes períodos e sob diferentes ângulos.

Nossa análise se inicia com os estudos de Hannah Arendt e Andre Gorz, que discutem o trabalho e suas transformações ao longo da história, tomando como ponto de partida as características do trabalho na antiguidade clássica.

Na sequência passamos a enfatizar as características do trabalho na modernidade, com o surgimento da Revolução Industrial e as teorias do valor-trabalho.

Neste período o trabalho atrelado à atividade industrial adquire uma função central na economia do período e, por consequência uma centralidade nas formulações teóricas de pensadores como Adam Smith, David Ricardo, Karl Marx, Max Weber.

Por meio da análise das obras dos pensadores citados acima iremos discorrer sobre a importância do trabalho humano para a economia industrial, expressa pelas teorias do valortrabalho, que passa a ser considerado como a medida real de valor de troca de todas as mercadorias. Ou seja, a quantidade de trabalho necessária para produzir uma mercadoria torna-se a medida real de valor. 
A partir da análise teórica de alguns dos principais autores do período a força de trabalho torna-se uma mercadoria, que pode ser adquirida no mercado de trabalho, dando origem a uma sociedade baseada no trabalho.

Em meio a estas formulações teóricas passamos a assistir, com a chegada do século XX, o desenvolvimento cada vez maior da tecnologia e a chegada da Era da Informação, promovendo a crise da Sociedade do Trabalho.

Já na segunda metade do século XX, autores como Alvin Toffler (1973; 1980), Yoneji Masuda (1980), John Naisbitt (1983), e Peter F. Drucker (1993) acentuam suas análises sobre as profundas transformações do trabalho, em um período que assinala o fim de uma Era Industrial e o início da preconizada Era da Informação.

Com as transformações em curso, principalmente na segunda metade do século $\mathrm{XX}$, o emprego industrial, predominante até então, dá lugar a outras formas de trabalho. O advento da tecnologia da informação aplicada cada vez mais a serviço da produção industrial promove o aumento da produção, que passa a depender cada vez menos do trabalho humano, do trabalho braçal, do operário da indústria.

A partir deste ponto ocorre uma mudança significativa nas relações de trabalho na chamada Sociedade do Trabalho. Passa a ocorrer a desvalorização crescente do trabalho industrial, realizado pelo operário com baixa qualificação e passa a ocorrer a valorização do trabalho cada vez mais especializado, bem como o trabalho em serviços.

Neste ponto, para Claus Offe, o momento atual do capitalismo financeiro sinaliza para o fim do trabalho como o conhecemos, além da perda do poder do trabalho como um pilar da sociedade.

Já num sentido contrário, outros pensadores, entre eles Ricardo Antunes, longe de presenciarmos o fim do trabalho, o que observamos é uma expansão da massa de proletários em todo mundo, em um tipo de trabalho cada vez mais precarizado, realizado por um conjunto variado de diferentes tipos de trabalho.

Para Antunes, a compreensão da classe trabalhadora hoje, deve incluir, além do proletariado industrial e rural, os assalariados do setor de serviços, aos quais podemos acrescentar aqueles inseridos nos bancos, no comércio, nos serviços públicos e também no lazer e no turismo.

Neste ponto podemos conjugar os conhecimentos desenvolvidos no capítulo 2, para compreender como o trabalho no turismo, que surge como uma atividade periférica em razão 
da centralidade do trabalho na indústria durante os séculos XIX e XX passa a ser trazido à tona sendo apontado como um importante setor gerador de empregos na economia atual.

Para compreendermos melhor este contexto e realizar uma análise crítica ao discurso dominante precisamos avançar para o capítulo 3, procurando entender as características do trabalho no turismo e tecer as nossas considerações finais.

No capítulo 3, portanto, nos dedicamos completamente ao entendimento das características de trabalho no turismo. Iniciamos uma leitura do turismo a partir dos estudos da Organização Mundial do Turismo, contrapondo os aspectos ressaltados e as benesses do turismo, com uma leitura crítica do trabalho no turismo, por meio dos estudos de Britton (1979, 1982), Shaw e Williams (2002), Cruz (2003, 2007, 2018) e Cañada (2017).

Quanto ao trabalho no turismo no Brasil, nossa análise inicial será introduzida pelos estudos pioneiros de Rabahy (1995) e Arbache (2001). A estes trabalhos introdutórios no setor incorporamos uma sequência de estudos realizados pelo IPEA, no período entre 2003 a 2015, que pode ser considerado como um dos mais importantes marcos do estudo sobre o trabalho no turismo no país.

O IPEA vem, desde 2003, trabalhando no desenvolvimento do Sistema Integrado de Informações sobre o Mercado de Trabalho no Setor Turismo - SIMT, em parceria com o Ministério do Turismo - MTur. O objetivo do SIMT é oferecer, sistematicamente, para o governo e a sociedade, informações sobre a ocupação nas atividades características do turismo - ACTs, com vistas a subsidiar a elaboração, a avaliação e o acompanhamento de políticas públicas e também o desenvolvimento do setor.

Os estudos do IPEA, quando analisados em conjunto, podem ser considerados como a melhor base de pesquisa sobre o tema no país. Os resultados apresentados nas pesquisas são fruto de uma metodologia própria, desenvolvida especialmente para lidar com as dificuldades do tema, que inclui o levantamento da base de dados sobre emprego no país e o estabelecimento de um coeficiente de demanda no turismo.

As estimativas da ocupação formal do setor turismo são feitas a partir do cruzamento dos dados sobre o número de ocupados declarados na Relação Anual de Informações Sociais RAIS, e pelo Cadastro Geral de Empregados e Desempregados - CAGED, do Ministério do Trabalho e Emprego - MTE, para um conjunto selecionado de atividades, filtrados por um coeficiente de demanda turística, que expressa a porcentagem de atendimento a turistas nos estabelecimentos pesquisados. 
Nosso trabalho, portanto, implicou na realização de uma ampla análise da documentação produzida pela IPEA, a fim de identificar algumas das principais características do trabalho no turismo no Brasil, adotando uma base metodológica única, que permitiria uma maior coerência nos números, análise e resultados.

Por meio dos resultados observados obtivemos uma melhor visibilidade das características do trabalho no turismo no país, possibilitando analisar, com uma base metodológica melhor estruturada, o discurso acrítico que se impõe e que propõem para o setor do turismo, um papel de protagonismo na solução das questões de geração de trabalho e renda no país.

Para finalizar devemos acrescentar que esta dissertação de Mestrado é fruto de um projeto acadêmico pessoal, que tem em sua concepção inicial três partes distintas.

A primeira parte é essa que aqui apresentamos: a dissertação de Mestrado, que trata do trabalho no turismo em uma concepção mais ampla, que analisa o trabalho no turismo com um foco específico na escala nacional e que, aqui concluída, contribui de forma efetiva, para uma melhor compreensão do fenômeno do turismo na atualidade, sobretudo no que tange à questão do emprego no setor.

Já a segunda e a terceira partes, ainda em projeto, consistem em dois futuros estudos de caso, com um recorte escalar mais restrito.

Quanto à segunda parte de nosso projeto acadêmico pretendemos estudar o trabalho no setor da hotelaria, em especial a hotelaria paulistana, a mais ampla, diversificada e desenvolvida do país, principalmente a hotelaria recentemente instalada, com a forte presença de redes internacionais de hotéis numa região geográfica concentrada e de expansão recente na região das Avenidas Marginal Pinheiros, Luís Carlos Berrini e Nova Faria Lima. Os hotéis representam importante papel na oferta de serviços turísticos, além de empregar grande contingente da força de trabalho no turismo e protagonizando substanciais transformações quanto ao trabalho, ao longo dos últimos anos.

Já na terceira e última parte deste projeto acadêmico pessoal pretendemos avançar com mais dois estudos de caso, em duas outras ACTs: Agências de Viagem e Transporte Aéreo que, juntamente com o trabalho na ACT Hospedagem, conformam o chamado núcleo duro do turismo. As duas ACTs citadas, nos dias atuais, passam por profundas transformações, que 
impactam fortemente a organização do trabalho, caracterizando-se também como importantes objetos de pesquisa. 


\title{
Capítulo 1 As transformações do trabalho e do mundo do trabalho
}

\begin{abstract}
Quando vemos uma jarra de argila produzida há cinco mil anos por algum artesão anônimo [...], com um propósito bem definido [...], talvez guardar água ou óleo, em moldando a terra moldou a si próprio. [...] Estruturando a matéria, também dentro de si ele se estruturou. Criando ele se recriou.
\end{abstract}

Fayga Ostrower, Criatividade e processos de criação (1987).

\subsection{O trabalho humano}

Por meio da bela passagem expressa na obra de Fayga Ostrower podemos compreender que o trabalho humano tem muito a revelar sobre o próprio homem e todo o seu entorno. Todo trabalho humano é criação e recriação de nós mesmos, enquanto indivíduos e enquanto sociedade.

É por meio do trabalho que o ser humano transforma o mundo e transforma-se a si mesmo, a tudo e a todos em seu redor. O homem, a sociedade e a natureza recriando-se continuamente.

O trabalho humano é, portanto, em síntese: transformação.

Falar do trabalho é falar de transformação. Transformação do ser humano, sua história e seu meio, sendo uma troca constante entre homem e natureza.

A esse respeito, podemos aqui reproduzir uma conhecida passagem de Marx, para o qual "antes de tudo, o trabalho é um processo entre o homem e a natureza, um processo em que o homem, por sua própria ação, media, regula e controla seu metabolismo com a natureza" (MARX, 2013, p. 326).

Milton Santos, por sua vez, reforça que é por meio do trabalho humano e da produção que se estabelece um ponto de partida para o entendimento das dinâmicas sociais que criam e transformam as formas e, portanto, a categoria de Formação Econômica e Social, elaborada por Marx e Engels, parece adequada para auxiliar a formação de uma teoria do espaço que seja válida (SANTOS, 1977, pp. 81-82).

Mas o próprio Milton Santos ainda questiona se "seria possível falarmos de uma Formação Econômica ou Social sem incluir a categoria do espaço”, já que não existe ação que ocorra fora do espaço. 
Se a Geografia deseja interpretar o espaço humano como o fato histórico que ele é, somente a história da sociedade mundial, aliada à da sociedade local, pode servir como fundamento à compreensão da realidade espacial e permitir a sua transformação a serviço do homem. Pois a História não se escreve fora do espaço, e não há sociedade a-espacial (SANTOS, 1977, p. 81).

A partir deste ponto, Santos propõe a noção de Formação Econômica Social e Espacial, sendo esta última mais complexa que a anterior, como vinha sendo desenvolvida até então.

A valorização da dimensão espacial se faz fundamental para o entendimento das especificidades dos lugares, deixando de considerar o espaço apenas como palco das ações humanas, apenas um território usado, um espaço banal. Ao contrário, partimos da existência de uma noção do espaço geográfico de todos os homens, instituições e empresas e de todas as dimensões do acontecer, atores hegemônicos e hegemonizados, com diferentes intenções e tentativas de uso do espaço, promovendo "dessa combinação, o arranjo singular dos lugares". Com isso, o espaço geográfico passa a ter um papel decisivo no estabelecimento destes singulares arranjos espaciais onde, por vezes temos o espaço como palco das ações humanas, enquanto outras temos o território como ator, em razão de suas características e rugosidades, tornando a sociedade o objeto das ações (SANTOS, 2000, pp. 108-109).

Após um posicionamento teórico acerca do papel da Geografia e sua contribuição para o entendimento do tema, podemos retornar ao nosso assunto central, no qual, é por meio do trabalho humano, que se constrói uma segunda natureza. É, por assim dizer, um processo entre o homem e o espaço, ou seja, uma transformação incessante do espaço por meio do trabalho humano.

Como podemos perceber, falar do trabalho humano não é tarefa simples. Ao contrário é um tema complexo, que pode ser trazido à discussão de várias maneiras, sob variados aspectos e pontos de vista.

Neste texto pretendemos trazer algumas visões e possibilidades de análise levando em conta alguns conceitos herdados principalmente da economia, da sociologia e da geografia. Mas queremos deixar claro que nossa intenção não é, e nunca poderá ter a pretensão de esgotar um assunto tão amplo. Ao contrário realizamos algumas escolhas conceituais para 
poder ilustrar certos aspectos do trabalho humano, que contribuem com nossas abordagens ao longo de todo estudo realizado.

Mas antes de avançarmos nesta breve discussão sobre o trabalho humano caberia aqui estabelecer certos limites de abordagem. Para fins deste estudo, este capítulo servirá como uma breve introdução sobre o trabalho e suas transformações, principalmente quando iremos tratar essencialmente do trabalho nas sociedades capitalistas desde o período moderno, até o período mais recente, quando pretendemos dar ênfase às profundas transformações pelas quais o trabalho vem passando.

Isso porque, nos dias de hoje, as transformações no trabalho e no mundo do trabalho adquirem uma importância central nos debates econômicos, políticos, nas ciências sociais e na sociedade em geral, em razão da profundidade de tais mudanças.

Um conjunto de mudanças associadas e de origens variadas tem provocado intensa reorganização na composição do trabalho gerando temores, ameaças e conflitos.

Essas mudanças, suas origens e resultantes para a sociedade atual têm sido nossa preocupação e objeto de análise. Em busca dessas respostas seguiremos em nossa dissertação identificando aspectos importantes de análise, que poderão nos ajudar a trazer respostas sobre os impactos no trabalho e no mundo do trabalho.

Mas para dar início ao assunto precisamos tecer alguns comentários sobre o trabalho humano e algumas de suas características. 


\subsection{O trabalho humano e suas diferentes possibilidades de análise}

Como já dissemos o trabalho humano não é algo simples de ser estudado, já que existem diferentes formas de analisá-lo. Isso ocorre em razão de que o trabalho possui um aspecto central na sociedade humana, tanto para a reprodução, quanto para a manutenção da vida e, portanto incorre em interpretações das mais variadas.

Em razão de sua importância, variados campos do saber interessam-se por analisar suas características, suas formas, seus impactos e demais aspectos. Podemos, por exemplo, encontrar estudos sobre o trabalho no campo Jurídico, na Medicina, no campo sindical, bem como em outras áreas do conhecimento, como na Psicologia, Economia, Sociologia, na própria Geografia, entre outros.

Para efeitos desta pesquisa compreenderemos o trabalho a partir de uma abordagem que encontra forte amparo nas fundamentações teóricas de importantes autores da Sociologia, da Economia e da Geografia, como Adam Smith, David Ricardo, Karl Marx, Max Weber, Milton Santos, David Harvey, Ruy Moreira, Márcio Pochmann e Ricardo Antunes, entre outros.

Além das concepções teóricas dos autores citados, também iremos pautar nossas análises do trabalho a partir do conceito de divisão do trabalho, ou seja, como este se organiza entre os membros que compõem uma sociedade, e também pela concepção marxista de modos de produção.

Para iniciar nossas considerações iremos primeiramente analisar a organização do trabalho nas diferentes sociedades humanas, desde suas formas mais simples às mais complexas.

Podemos iniciar dizendo que nas sociedades ditas primitivas ou mesmo as sociedades tribais, por exemplo, é comum identificar uma divisão do trabalho, caracterizada como uma divisão sexual do trabalho, onde o mesmo é dividido de forma diferente de acordo com o sexo, ou seja, homens e mulheres desenvolvem tarefas distintas entre si, estabelecendo uma divisão mais ou menos clara no conjunto de tarefas a serem realizadas entre todos. Em geral, aos homens caberia a provisão (a caça, a pesca, a criação de animais, etc.), enquanto que às mulheres caberiam as atividades de manutenção da vida, como a criação dos filhos, a preparação de alimentação, etc. 
Entre grupos humanos que atingiram níveis de organização social mais complexo, o trabalho irá se organizar também de formas mais complexas.

Hannah Arendt esclarece que, na antiguidade clássica o saber filosófico apresentava-se como o aspecto de maior valor social e, portanto, a vita contemplativa era o único modo de vida realmente livre, conforme nos faz perceber a passagem abaixo:

[...], a enorme superioridade da contemplação sobre qualquer outro tipo de atividade, inclusive a ação, não é de origem cristã. Encontramo-la na filosofia política de Platão, onde toda a reorganização utópica da vida na polis é não apenas dirigida pelo superior discernimento filosófico, mas não tem outra finalidade senão tornar possível o modo de vida filosófico (ARENDT, 1987, p. 22).

Robert Schlaifer (1936), em seu estudo Greek Theories of Slavery from Homer to Aristotle, acrescenta que o próprio Aristóteles, em sua famosa discussão da escravidão, afirmava que,

[...] sem o necessário, nem a vida nem a boa vida é possível. Ter escravos é a forma humana de dominar a necessidade e, portanto, não é contra a natureza; a própria vida o exige. Portanto, os camponeses que produzem o necessário para a vida são classificados, tanto por Platão, como por Aristóteles, na mesma categoria que os escravos (SCHLAIFER apud ARENDT, 1987, p. 94).

Dada uma das principais características da sociedade naquele período, segundo Arendt, para os gregos, a instituição da escravidão na antiguidade não foi uma forma de obter mão-de-obra barata, nem instrumento de exploração para fins de lucro, mas sim a tentativa de excluir o labor das condições da vida humana. Os escravos e os membros da espécie humana totalmente sujeitos à necessidade eram considerados animais laborans. "Laborar significava ser escravizado pela necessidade, escravidão esta inerente às condições da vida humana" (ARENDT, 1987, p. 94).

Com o advento da teoria política, os filósofos aboliram as distinções que havia entre as atividades, tanto do animal laborans (o labor do nosso corpo), quanto do homo faber (o trabalho de nossas mãos), e opuseram a contemplação a todo e a qualquer tipo de atividade. Até mesmo a ocupação política foi rebaixada à posição de necessidade, elevando ao máximo a concepção de vita contemplativa (ARENDT, 1987, p. 95). 
Outra importante característica do trabalho naquele período é apresentada por André Gorz, que nos esclarece que o trabalho na Grécia antiga permanece confinado na esfera privada. Na sociedade grega a esfera privada e a família confundiam-se com a esfera das necessidades econômicas e do trabalho, enquanto que a esfera pública era destinada à política (GORZ, 2007, p. 23).

Em complemento à visão trazida por Hannah Arendt, André Gorz acrescenta que, "até o século XVIII, o termo 'trabalho' (labour, arbeit, lavoro) designava a labuta dos servos e dos trabalhadores por jornada, produtores de bens de consumo ou dos serviços necessários à sobrevivência que, dia após dia, exigem ser renovados e repostos". Todavia, a ideia contemporânea de trabalho somente surge, em definitivo, com a ascensão do capitalismo manufatureiro (GORZ, 2007, p. 24).

Com o fim da Idade Média, o início da Era Moderna e o surgimento do capitalismo manufatureiro, conforme propõe Gorz, passa a ocorrer outra forma de organização do trabalho, que podemos chamar de uma divisão social do trabalho.

A denominada divisão social do trabalho passa a ocorrer com uma clara distinção entre aqueles que realizam o trabalho propriamente dito e aqueles que controlam e organizam ou administram o trabalho. Esta nova divisão acaba, entretanto, contribuindo para um aumento da desigualdade, já que cada tipo de tarefa tem uma valoração diferente no interior da própria sociedade.

Com a divisão social do trabalho aprofundam-se as diferenças entre aqueles que controlam o trabalho (por exemplo, os capitalistas, detentores dos meios de produção) e aqueles que executam o trabalho (os proletários, excluídos dos meios de produção e que necessitam vender a sua força de trabalho como única fonte de sobrevivência).

No interior das sociedades mais complexas, com uma divisão social do trabalho também mais complexa podemos identificar uma chamada divisão técnica do trabalho, com maior e mais específica especialização do trabalho por parte de certos membros da sociedade, possibilitando a grupos de pessoas se diferenciem dos demais trabalhadores a partir de saberes e habilidades diferenciadas.

A esse respeito escreveu Adam Smith, em seu livro: "Investigação sobre as causas da riqueza das nações", um famoso texto que procura retratar a situação onde indivíduos de uma sociedade primitiva, com maior habilidade para produzirem arcos e flechas mais perfeitos do que outros deveriam especializar-se nessas atribuições. Assim poderiam trocar esses seus produtos com seus companheiros, obtendo assim mais gado e carne do que se fosse caçar ele mesmo, transformando-se assim numa espécie de armeiro (SMITH, 1776:1979, p. 14). 
Às portas da Revolução Industrial, Smith procurava, por meio de seu estudo, comprovar uma naturalidade da divisão técnica do trabalho e justificar a necessidade da especialização do trabalho humano, para atuação nas maquinofaturas, em substituição à manufatura vigente. Ou seja, a substituição do artesão, responsável por todas as etapas de produção de uma mercadoria (um calçado, por exemplo), por um operário da indústria, responsável por apenas uma parcela específica do processo de fabricação.

Com sua conhecida obra, Smith, discorre sobre um período de profunda transformação do trabalho no final do século XVIII, com a proliferação das fábricas e o crescimento do proletariado industrial, com o acirramento das diferenças sociais e a origem da luta de classes.

A sociedade industrial que iniciava seus passos com a Revolução Industrial cresceu às custas de levas cada vez maiores de novos operários (proletários) fazendo crescer a população das principais cidades europeias nos séculos seguintes.

Juntamente com a nova leva de operários ampliou-se também o que Marx chamou de "exército industrial de reserva", composto de homens, mulheres e crianças à procura de trabalho e que estavam à disposição das classes dominantes para conseguirem alguma ocupação que lhes garantissem a sobrevivência.

Essa situação se tornou comum a várias cidades industriais do velho continente, com suas poderosas fábricas, com numeroso número de trabalhadores, a irrigar o mundo com seus produtos industrializados.

Tal situação irá propiciar uma Divisão Internacional do Trabalho, que expressa uma condição onde caberá aos países centrais do capitalismo industrial o papel hegemônico de produção de mercadorias industrializadas - mais caras, enquanto que caberá às colônias o papel de exportadores de produtos agrícolas - mais baratos.

A Divisão Internacional do Trabalho - DIT permite compreender o espaço que cada nação irá ocupar nas relações do comércio internacional. As nações industrializadas e ricas e as nações, ou colônias, agrícolas e pobres, num cenário que se manteve com poucas alterações até os nossos dias e que contribui para explicar, ainda nos dias atuais, as profundas alterações no trabalho em tempos mais recentes.

Este cenário de profundas diferenças entre Estados também possibilita outra forma de interpretar o trabalho. Trata-se da Divisão Territorial do Trabalho, que permite explicar as diferenças de organização do trabalho nas diferentes porções do espaço geográfico mundial. Quando observamos o trabalho em escala planetária podemos observar a tradicional Divisão Internacional do Trabalho - nações industrializadas e ricas de um lado e nações e colônias agrícolas pobres, de outro, conforme já exposto. Porém podemos admitir outras escalas de 
análise, como a escala continental, a nacional, a regional, estadual ou municipal, ou mesmo algum outro recorte espacial específico e observar como se compõe a organização do trabalho em cada uma dessas porções do território.

Milton Santos observa que com o aprofundamento da divisão social do trabalho e da divisão territorial do trabalho analisados a partir da concepção de território usado, podemos compreender a "seletividade dos investimentos econômicos que gera um uso corporativo do território". No território usado, os distintos atores hegemônicos utilizam o território como um recurso e os atores hegemonizados têm o território como um abrigo (SANTOS, 2000, p. 108).

Pela análise de Milton Santos podemos compreender que há inúmeras possibilidades de identificar e analisar as diferentes formas de organização do trabalho e seus desdobramentos no espaço. Mas devemos entender que o conceito de divisão do trabalho não é a única forma de classificação possível.

Outra possibilidade é estudar o trabalho a partir do conceito de modos de produção.

Para compreender o conceito marxista de modo de produção precisamos inicialmente discorrer sobre os chamados meios de produção. Estes podem ser entendidos como os diferentes instrumentos utilizados na produção, como ferramentas, instalações, a terra, e os diferentes recursos naturais, como a água e demais fontes de energia.

Quando identificamos todos os meios de produção e adicionamos a estes o trabalho humano, ou seja, a força de trabalho, teremos a constituição das chamadas forças produtivas.

As forças produtivas, no entanto necessitarão serem postas em ação, para possibilitar a realização do trabalho e a realização da produção em si. Para que isto aconteça podemos entender que irão existir inúmeras interações entre indivíduos, grupos, entidades, empresas, etc., que, em conjunto e postas em ação irão determinar as relações de produção, que possibilitarão a formação de determinado modo de produção.

O modo de produção, portanto, irá incluir as relações de produção, e as forças produtivas, sendo esta última decomposta em força de trabalho, ferramentas, instalações e fontes de energia.

Por meio desta análise teórica dos modos de produção podemos entender que, ao longo dos séculos e em diferentes partes do planeta ocorreram diferentes modos de produção, que têm suas diferenciações a partir das relações sociais existentes e da maneira como o trabalho humano é organizado e realizado. 
Para ilustrar melhor esta situação podemos dar exemplos de diferentes modos de produção existentes na história da humanidade, como o escravista, o feudal, o capitalista, entre outros.

$\mathrm{Na}$ antiguidade clássica, como já exposto, podemos identificar um modo de produção escravista, onde, obviamente, as relações de dominação de um grupo sobre outro transforma o trabalho escravo na base de uma economia agrícola. Estes eram os responsáveis pelo trabalho na agricultura, na criação e em pequenas atividades de comércio ou domésticas. Os escravos eram propriedade do estado e repassados aos nobres, de acordo com seus poderes e influência.

Já no período feudal é conhecida a relação existente entre servos e senhores feudais. Os servos, base da sociedade feudal, trabalhavam a terra e com a colheita pagavam o Senhor feudal com parte do que produziam. Em troca recebiam o direito de acesso a terra, a própria subsistência, a proteção contra a invasão dos povos bárbaros, garantindo a existência do modelo. Este conjunto de relações formava a base do modo de produção feudal.

O modo de produção capitalista, no entanto, promove, para se estabelecer a superação do modo de produção feudal, já que ele é, antes de tudo, uma nova relação social, diferente das relações sociais estabelecidas anteriormente.

Nesta nova relação social o detentor do capital irá empregá-lo na compra de mercadorias, entre elas a força de trabalho e demais meios de produção com vistas a obter maior valor para aumento de seu capital inicial.

A constituição do valor, no entanto, se dará somente com a existência das condições sociais adequadas para a ocorrência da produção privada de mercadorias, possível somente por meio das relações de propriedade privada e do trabalho assalariado, onde o trabalhador, despossuído dos meios de produção, trabalha vendendo sua força de trabalho para os capitalistas.

Neste modo de produção, que passa a ser possível com uma maior complexidade das condições sociais de produção, o trabalho humano adquire uma posição central. O trabalho livre e assalariado transforma-se em força de trabalho social médio, sendo considerado, portanto a fonte de valor, o valor-trabalho, conceito desenvolvido por muitos pensadores do período, dando origem à sociedade do trabalho.

Mas para compreendermos melhor esta nova e mais complexa sociedade do trabalho precisaremos agora nos aprofundar em novos conceitos. 


\subsection{O trabalho no mundo capitalista: da teoria do valor-trabalho à sociedade do trabalho}

O final da Idade Média foi um período marcado por importantes fatos históricos como o início das grandes navegações, a expansão ultramarina e a colonização do Novo Mundo. Estes fatos provocam um expressivo crescimento do comércio na Europa, dando origem a um período conhecido por mercantilismo.

No mercantilismo os países mais avançados buscavam uma balança comercial favorável, incentivando a circulação de produtos e moedas. Para os autores do período era por meio da circulação das mercadorias e moedas, que toda riqueza era gerada.

Naquele período, um dos primeiros a ir além desta visão foi Sir Willian Petty (16231687), considerado por muitos como o pai da Economia Política de origem burguesa e que buscou, em sua obra, identificar as origens do valor. Para Petty, toda mercadoria tem um preço e uma quantidade de trabalho necessária à sua produção. Com isso, os lucros têm a sua origem no preço natural dos produtos, ou seja, no trabalho requerido para a produção.

Segundo Petty, o trabalho é o pai e a terra é a mãe de toda riqueza e, por isso, o trabalho ganha ênfase em suas teorias. Com Willian Petty surge a primeira formulação explicita da categoria valor enquanto valor-trabalho (MORAES; COSTA, 1993, pp. 94-96).

Outro importante autor da economia política clássica e também preocupado com a origem do valor foi Adam Smith (1723 - 1790). Smith foi professor da Universidade de Glasgow, da qual se tornaria reitor, após obter grande prestígio acadêmico em razão de sua obra, que vai ao encontro dos interesses econômicos da burguesia inglesa da época.

Sua obra, publicada em 1776, torna-se um marco decisivo da Economia Política clássica. Em seu livro: "Investigação sobre as causas das riquezas das nações", Smith apresenta, entre outras coisas, sua visão para os motivos do fenômeno da divisão do trabalho, como esta divisão sofre a influência do mercado e, por sua vez, influencia as trocas comerciais e o uso das moedas.

Mais precisamente no capítulo V, Smith discorre sobre o preço real e nominal das mercadorias, ou seja, o seu preço em trabalho e o seu preço em dinheiro. 
Neste capítulo Smith assevera que, com o advento da divisão do trabalho, a maior parte dos objetos é produzida pelo trabalho de outras pessoas, levando o leitor a considerar que um homem é rico ou pobre conforme a quantidade de trabalho que ele pode ter à sua disposição, ou que pode comprar. Logo, conclui:

[...] o valor de qualquer mercadoria, para a pessoa que a possui, e que não tenciona usá-la ou consumi-la, mas trocá-la por outras é igual à quantidade de trabalho que lhe permite adquirir. Logo, o trabalho é a medida real do valor de troca de todas as mercadorias (SMITH, 1776:1979, p. 27).

Dessa passagem podemos perceber que Smith entende o valor como valor-trabalho. Para ele, o trabalho é a medida real do valor de troca de todas as mercadorias.

Moraes e Costa apontam ainda que Smith "parte do pressuposto de que todo valor de troca de uma dada mercadoria é igual à quantidade de trabalho que ela contém. Por isso, sempre que se concretiza o ato da troca, o consumidor estará, em verdade, adquirindo, por um certo valor em dinheiro, uma certa quantidade de trabalho". Para Smith, esta é a medida real de valor. "De qualquer modo, será sempre o trabalho, a verdadeira e mais segura medida de valor. Isto porque, para o trabalhador, o trabalho tem valor invariável: é sempre uma dada quantidade necessária à sua reprodução enquanto trabalhador. O que muda é o valor desse trabalho para o capitalista, pois nesse caso ele varia em função do preço" (MORAES; COSTA, 1993, pp.100-101).

Para Smith,

[...] em todos os tempos e lugares é caro aquilo que dificilmente se pode conseguir ou que só pode ser adquirido em troca de muito trabalho; e barato aquilo que se pode ter facilmente ou que custa muito pouco trabalho. É, portanto, este, cujo valor nunca varia, que surge como a verdadeira e definitiva medida de valor das mercadorias em todos os tempos e lugares. É ele seu preço real; o dinheiro é apenas o seu preço nominal (SMITH, 1776:1979, p. 29).

Ainda no campo da Economia Política Clássica, Moraes e Messias destacam a obra de David Ricardo. Ricardo parte do valor-trabalho, porém o introduz a ideia de que o valor é determinado pelo tempo do trabalho, sendo este um valor relativo. A ideia de que o tempo de 
trabalho determina o valor das mercadorias, mas não somente o trabalho realizado na produção das mercadorias (trabalho novo), mas também aquele já contido nas matériasprimas, máquinas e equipamentos (trabalho pretérito).

\begin{abstract}
Ele retira a origem do valor dos limites estreitos da produção imediata, do seu funcionamento 'natural'. O tempo de trabalho e a mais-valia passam a ser vistos como o 'ponto de partida' de toda acumulação. [...] Como diz Marx, ele distingue e aponta a contradição entre o 'funcionamento real' e o 'funcionamento aparente' do sistema. Entre o valor das mercadorias determinado pelo trabalho invertido no ato de sua produção (aparência) e o trabalho global, empregado tanto na produção imediata, quanto aquele prévio, despendido na produção dos instrumentos, máquinas, edifícios etc. (o valor real) (MORAES; COSTA, 1993, pp.102-104).
\end{abstract}

Moraes e Costa ainda apontam que, com David Ricardo encerra-se o período da Economia Política, e que caberá a Marx a Crítica à Economia Política. "Para Marx, o valor é, antes de tudo uma categoria social. Não há valor sem trabalho. Concebe-o em seu duplo significado: valor de uso e valor de troca". O valor de uso representa a utilidade dos produtos para a satisfação das necessidades humanas, enquanto que o valor de troca baseia-se na utilidade do produto para consumo alheio, o que o torna apto à troca (MORAES; COSTA, 1993, pp.110).

A esse respeito, Moraes e Costa ainda reforçam que,

[...] assim a mercadoria, na sociedade capitalista, aparecerá como unidade contraditória entre o valor de uso e o valor de troca. No valor de troca não importam mais as qualidades intrínsecas dos produtos, mas exclusivamente a sua virtualidade para a circulação. A possibilidade da troca reside na existência de uma equivalência geral entre as mercadorias. Esse equivalente é o trabalho humano em geral (abstrato) contido nas mercadorias [...], o trabalho humano homogêneo, "força média de trabalho social" (MORAES; COSTA, 1993, p.111).

Marx então identifica que o próprio trabalho torna-se uma mercadoria, a "força de trabalho", que como qualquer outra mercadoria, também tem o seu valor de uso e o seu valor de troca. O valor de uso do trabalho é o trabalho humano concreto empregado na produção de bens e mercadorias, enquanto que o valor de troca é o trabalho abstrato, ou seja, a parcela de trabalho equivalente à média do trabalho humano, que pode ser usado como equivalente para 
a troca no mercado de trabalho que se encontra em qualquer trabalho, ou seja, pode ser comprada pelos detentores do capital, por meio de salários.

A partir desta conceituação, Marx aponta que o trabalho humano torna-se uma mercadoria, como todas as outras, podendo ser comprada no mercado capitalista como qualquer outra mercadoria. Os donos do capital irão precisar então de terra, adquirida no mercado de terras; trabalho, adquirido no mercado de trabalho; o próprio capital, nos bancos; e os demais meios de produção para reprodução do capital.

Desta concepção Marx apresenta o conceito de mais-valia, que é a parte do trabalho não pago aos trabalhadores pelos capitalistas, dando origem ao lucro.

Ainda quanto à mais-valia, Marx estabelece a diferença entre a mais-valia absoluta e a mais-valia relativa.

A mais-valia absoluta surge a partir do aumento do ritmo de trabalho. O capitalista exige maior empenho na produção e em troca obtém um aumento da produção de excedentes, que transforma em maior lucro e aumento do capital.

A mais-valia relativa, por sua vez, estabelece-se a partir da melhoria do processo produtivo e por meio do avanço científico e tecnológico. O capitalista utiliza-se de melhorias científicas e tecnológicas para acelerar a produção e aumentar a quantidade produzida. Com esse processo ocorre o aumento do lucro e a redução da necessidade de trabalho humano, que passa, aos poucos, a ser substituído por máquinas mais sofisticadas. A necessidade de trabalho é diminuída e a mão de obra substituída por um maquinário, com cada vez mais tecnologia.

Com esta formulação, Marx expôs definitivamente as contradições inerentes ao modo de produção capitalista: a exploração do trabalho e a acumulação do capital.

É interessante notar que o trabalho humano, enquanto origem e gerador de valor no período moderno, quanto mais valor produz, mais se desvaloriza. $\mathrm{O}$ trabalho cada vez mais vai perdendo seu valor, tanto pela extração da mais-valia absoluta, quanto pela mais-valia relativa, por meio da substituição do trabalho humano pelo emprego da tecnologia, conforme veremos com mais detalhes adiante.

Neste momento, o trabalho que havia deixado de ser algo indesejado e relegado aos escravos, ao longo de toda a antiguidade clássica, passa a se tornar a fonte de todo valor na modernidade, adquire uma condição contraditória, segundo Marx, levando à formulação do 
conceito da luta de classes, onde capitalistas e operários se confrontam diariamente naquilo que já é considerado a origem de todo o valor: o valor-trabalho.

$\mathrm{Na}$ chamada Era Industrial a fábrica passa a ser o centro das disputas entre as classes antagônicas. De um lado os capitalistas: detentores das forças produtivas, os meios de produção (instrumentos de produção, fábricas, armazéns, água, energia) e da força de trabalho, e do outro lado os trabalhadores, operários, despossuídos de tudo, menos de sua "liberdade" de vender a sua força de trabalho em troca de um salário.

Neste eterno embate, capital e trabalho se conflitam, se nutrem diariamente e ao longo de séculos, enquanto a produção de bens e mercadorias torna-se a locomotiva da economia mundial.

Nesse período a produção industrial transforma as principais cidades europeias, como: Londres, Manchester, Paris, e as cidades alemãs no vale do rio Ruhr, que crescem de forma desordenada, com cortiços apinhados de operários de todas as idades e procedências.

É a Revolução Industrial promovendo uma grande transformação econômica, política, social e espacial. A indústria emprega cada vez mais gente, pois o trabalho fabril torna-se a principal fonte de sustento de milhões de despossuídos, que singram a Europa em busca de algum trabalho nos galpões industriais obscurecidos daquela época.

Com este processo emerge a chamada sociedade do trabalho, que segundo Ruy Moreira, "é uma forma de relação societária que surge na decorrência do surgimento do trabalho abstrato. Este é um marco que divide as sociedades em capitalistas e pré-capitalistas na história das sociedades" [...]. O próprio Ruy Moreira ainda reforça, mais adiante, que "as sociedades capitalistas distinguem-se de todas as outras pela presença do trabalho abstrato produtor e fruto do valor-trabalho - e assim da formatação societária de base numa sociedade do trabalho" (MOREIRA, 2016, p.55).

Esta sociedade do trabalho será, para nós, a partir daqui, um ponto importante de análise, pois é fruto imanente das relações oriundas do modo de produção capitalista e, portanto, contendo toda sua contradição. A sociedade do trabalho vir-se-á numa dicotomia constante, na necessidade de produzir mais mercadorias e com isso mais trabalho abstrato, contido na força de trabalho, de onde se extrai a mais-valia relativa. 
Nesta relação, o trabalho vai cada vez mais perdendo seu valor, pela extração da maisvalia relativa e com a substituição do trabalho humano.

Neste ponto, o capital não é mais uma coisa, mas uma relação social que se expressa por meio das coisas e domina tudo ao seu redor: mercadorias, força de trabalho, meios de produção...

Outra importante visão sobre o trabalho no século XIX pode ser atribuída ao sociólogo Max Weber (1864 - 1920). Weber, em seu livro "A ética protestante e o espírito do capitalismo", propõe que o capitalismo existe, antes de tudo, enquanto um espírito, uma cultura, e não somente um sistema econômico ou um modo de produção.

Para Weber o capitalismo já existia na China, na Índia, na Babilônia, na Antiguidade e na Idade Média. Mas para o autor "faltava-lhe esse ethos peculiar, que somente a revolução burguesa e a Reforma Protestante trariam posteriormente ao capitalismo do século XIX" (WEBER, 2004, p. 45).

A Reforma Protestante permite o desenvolvimento de uma ética, uma lógica, uma forma própria de pensar, que invade a Europa Ocidental e posteriormente a América do Norte. Com a Reforma há o rompimento com a fé católica e a forma de pensar da igreja e dos mosteiros.

Com esta mudança, Weber ressalta que "a importância da Reforma Protestante significou não apenas a eliminação da dominação eclesiástica sobre a vida de um modo geral, quanto a substituição de sua forma vigente por uma outra” (WEBER, 2004, p. 30).

Uma outra lógica, que ressalta o trabalho e o dinheiro, onde, segundo o autor, "o ganho de dinheiro na moderna ordem econômica é, desde que feito legalmente, o resultado e a expressão da virtude e da eficiência em um certo caminho”. Ainda segundo Weber, o espírito capitalista da época pode ser percebido pela citação que o autor faz sobre o pensamento de Benjamim Franklin (1706 - 1790): "Vês um homem diligente em seus afazeres? Ele estará acima dos reis." (Provérbios 22:29) (WEBER, 2004, p. 21).

É importante frisar, na obra de Weber, que o ganho exagerado, sem qualquer regra ou norma de conduta sempre existiu em várias regiões e em todos os períodos da história, conforme citamos anteriormente, mas que o chamado "espírito capitalista moderno requer 
uma certa conscientização dos operários à lógica capitalista burguesa, sem a qual ocorrerá um obstáculo ao desenvolvimento do próprio capitalismo" (WEBER, 2004, p. 50).

Em certo trecho de sua obra, Weber chama atenção à era pré-capitalista, aquela na qual a valorização racional do capital e a organização capitalista do trabalho ainda não haviam se tornado as dominantes na orientação da ação econômica. Nesta era pré-capitalista começa a ocorrer a transformação do trabalho caseiro e artesanal para o trabalho capitalista moderno, organizado contabilmente e realizado em fábricas.

Weber chama este novo modelo que se impõem ao anterior de "ordem econômica de cunho capitalista-burguês" (WEBER, 2004, p. 51).

Nesta nova ordem, Weber discute a questão dos deveres do mundo, onde o trabalho profissional aparece como expressão maior do amor ao próximo, sendo "cada vez mais enfática ao cumprimento dos deveres intramundanos como a única via de agradar a Deus em todas as situações". Nesse sentido, toda profissão lícita vale muito e tem igual valor perante Deus. Este aspecto revela, na lógica protestante, uma profunda relação entre a fé religiosa e a ética profissional (WEBER, 2004, pp. 73-83).

Para expressar melhor sua teoria Max Weber cita algumas frases do líder protestante inglês Richard Baxter, que viveu entre 1615 a 1691, às quais consideramos importante resgatar:

- "perda de tempo é, assim, o primeiro e, em princípio, o mais grave de todos os pecados". (WEBER, 2004, p. 143);

- "sem valor, portanto, quando não diretamente condenável, é também a contemplação inativa, ao menos quando feita à custa do trabalho profissional" (WEBER, 2004, p. 144);

- "com certeza, não para fins de concupiscência da carne e do pecado, mas sim para Deus, é permitido trabalhar para ficar rico.” (WEBER, 2004, p. 148).

Como podemos perceber, para Weber a fé religiosa e a ordem econômica se conjugam e se orientam de modo peculiar no capitalismo industrial do século XIX, desdobrando-se sobre o trabalho e toda a sociedade. Para Weber a pedra fundamental que sustenta esses dois elementos de forma tão coesa é a concepção de moral cristã que constrói um conjunto de práticas e disciplinas valorizando a austeridade, o autocontrole do corpo e do espírito, em busca da realização dos desígnios de Deus. 
"Um dos elementos componentes do espírito capitalista moderno, e não só deste, mas da própria cultura moderna: a conduta de vida racional fundada na ideia de profissão como vocação nasceu do espírito da ascese cristã” (WEBER, 2004, p. 164).

Pois a ascese, ao se transferir das celas dos mosteiros para a vida profissional, passou a dominar a moralidade intramundana e assim contribuiu [com sua parte] para edificar esse poderoso cosmos da ordem econômica moderna ligada aos pressupostos técnicos e econômicos da produção pela máquina, que hoje determina com pressão avassaladora o estilo de vida de todos os indivíduos que nascem dentro dessa engrenagem - não só dos economicamente ativos — e talvez continue a determinar até que cesse de queimar a última porção de combustível fóssil (WEBER, 2004, p. 165).

Pela passagem do autor, parece que Weber já antevia a finitude dos combustíveis fósseis, e o esfacelamento de um modelo que produziu tantas riquezas ao longo de tantos séculos. Modelo este que parece ruir juntamente com o trabalho industrial e a sociedade do trabalho.

Avancemos, portanto, para o próximo item para conhecer melhor as mudanças em curso. 


\subsection{O conhecimento como valor: a Era Pós-industrial e a crise da sociedade do trabalho}

Em 1971, o escritor Alvin Toffler, apresentava ao mundo seu livro "O choque do futuro", ressaltando o acelerado processo de mudanças, suas consequências para a sociedade e a antecipação de uma crise, em razão da "rapidez com que se verificavam tais mudanças e as alterações sociais", daquela época.

Para o autor,

... a sociedade ocidental, nestes últimos trezentos anos, tem sido arrastada num turbilhão de transformações. Este turbilhão, longe de atenuar-se, parece que agora ganha uma densidade maior de forças. As transformações se expandem através dos países altamente industrializados, em ondas de uma velocidade que cada vez mais se acelera e com um impacto sem precedentes... (TOFFLER, 1973, p. 3)

Toffler assinalava também que, "para a maioria das pessoas, o termo tecnologia convoca o aparecimento de imagens de fábricas de aço soltando as suas fumaças ou então a visão de máquinas barulhentas" (TOFFLER, 1973, p. 17).

O autor queria ressaltar que o símbolo clássico da tecnologia daquela época, ainda era a linha de montagem criada por Henry Ford há meio século e transformada num poderoso ícone social, no filme "Tempos Modernos", de Charlie Chaplin.

Este símbolo, no entanto, parecia inadequado para Toffler, que dá ênfase à tecnologia e ao ciclo da inovação, que se alimenta dela mesma, avançando aceleradamente e provocando mudanças generalizadas nas sociedades ocidentais (TOFFLER, 1973, pp. 17-21).

Na introdução de seu livro, Toffler sinalizava que,

[...] recentemente, o computador provocou uma avalancha de ideias novas acerca do homem como uma parte integrante de sistemas mais amplos, acerca de sua filosofia, da maneira por que aprende as coisas, da maneira por que se recorda dos fatos, da maneira por que toma suas decisões [...]. Se a tecnologia, no entanto, tiver de ser tomada como uma grande máquina, uma poderosa força aceleradora, então o conhecimento deve ser reconhecido como seu combustível (TOFFLER, 1973, p. 21).

Nesse sentido, avança o autor, dizendo que o conhecimento é poder e transformação. E que a aquisição cada vez mais rápida do conhecimento, como combustível para a grande 
máquina da tecnologia, acelera ainda mais as transformações em curso. Em outras palavras, promovendo o "choque do futuro".

Já em seu livro posterior: “A Terceira Onda”, entregue ao público em 1980, portanto, nove anos depois, Toffler propõe a tese de que o atual estágio do conhecimento humano, presente em grande parte dos países desenvolvidos do ocidente, estaria promovendo uma revolução sem precedentes na história da humanidade.

O livro divide a civilização em apenas três partes: A Primeira Onda - uma fase agrícola; a Segunda Onda - uma fase industrial; e a fase que estaria começando àquela época, a Terceira Onda - que estaria promovendo a morte do industrialismo e o advento de uma nova civilização.

\footnotetext{
A Terceira Onda descreve a civilização industrial moribunda em termos de uma "tecnosfera", uma "sociosfera", uma "infosfera" e "poderesfera", depois dispõe-se a mostrar como cada uma destas está sofrendo uma mudança revolucionária no mundo atual; tenta mostrar as relações destas partes de uma com cada outra, bem como com a "biosfera" e "psicosfera" - essa estrutura de relações psicológicas e pessoais através da qual mudanças ocorridas no mundo exterior afetam as nossas vidas mais íntimas (TOFFLER, 1980, pp. 18-19).
}

Toffler acreditava que esta nova civilização, desafiando a velha, reduziria as burocracias, reduziria o papel dos Estados-nação, criando governos mais simples, promovendo uma própria perspectiva diferente do mundo, seus próprios modos de lidar com o tempo, o espaço, a lógica e a causalidade.

Quanto ao trabalho nesta nova civilização, Toffler propõe que, quando emerge a Terceira Onda, o trabalho torna-se menos repetitivo, menos fragmentado, com cada pessoa fazendo uma tarefa maior e não menor. O tempo flexível e o ritmo próprio substituem a sincronização em massa, os trabalhadores terão que enfrentar frequentes mudanças em suas tarefas, além de sucessivas transferências de pessoal, mudanças de produtos e reorganizações (TOFFLER, 1980, p. 378).

A firma da Segunda Onda frequentemente recompensava pela obediência ao comportamento burocrático. A firma da Terceira Onda exige pessoas que sejam menos pré-programadas e mais criativas. [...] A diferença [...] é como a que existe entre os músicos clássicos, que tocam cada nota de acordo com uma configuração predeterminada e estabelecida, e os improvisadores do jazz que, uma vez tendo 
decidido que canção tocar, pegavam sensivelmente as deixas um do outro e, na base disso, decidiam que notas tocar. [...] Tais pessoas são complexas, individualistas, orgulhosas das maneiras como diferem umas das outras. Elas tipificam a força de trabalho desmassificada, necessária para a indústria da Terceira Onda (TOFFLER, 1980, p. 378).

O sociólogo japonês Yoneji Masuda foi outro autor daquele período, que analisava as mudanças em curso no auge da sociedade industrial. No final da década de 1970, no prefácio de seu livro: "A sociedade da informação como sociedade pós-industrial”, Masuda, assim como Toffler, também ressalta que "a humanidade está vivendo um período de transformação de uma sociedade industrial para uma sociedade da informação".

Para Masuda, quando olhamos para trás observamos três tipos de sociedades humanas: a da caça, a agrícola e a industrial, sendo que as rápidas inovações de uma época tornam-se as principais forças motoras das transformações sociais, dando origem à própria transformação da sociedade em uma nova forma diferente daquela que já se tornara tradicional.

Com base nisso, o homem se encontraria agora no limiar de um novo período de inovações tecnológicas, estas baseadas na combinação de tecnologias de telecomunicações e informática, onde a substância é a informação.

Segundo o autor, a época da informação terá um papel mais decisivo na sociedade humana do que a "revolução da energia", que gerou a invenção da máquina a vapor. Isso porque o computador amplifica o trabalho mental humano, enquanto que a máquina a vapor amplificou o trabalho físico (MASUDA, 1980, p. 67).

Masuda ainda destaca que o impacto das inovações tecnológicas trarão possibilidades brilhantes e também sombrias. O primeiro impacto será a emancipação do trabalho humano de subsistência.

$\mathrm{Na}$ era da agricultura, o homem esteve preso à terra. Na era industrial, os trabalhadores foram confinados às fábricas [...] e seus escritórios. Entretanto, uma vez que uma porção maior do trabalho em escritórios e na produção industrial será substituída por computadores, haverá menos necessidade de homens e mulheres servirem como meio de armazenamento e comunicação de informação, que é, afinal, a principal razão do envolvimento humano em boa parte do trabalho organizado. Assim, o homem não só irá emancipar-se da necessidade de trabalhar para a sua subsistência, como também libertar-se-á dos laços que o prendem aos locais de produção (MASUDA, 1980, p. 81). 
A liberação ou emancipação humana do trabalho organizado, ou dos locais da produção irão produzir, na era da informação, o chamado tempo livre, que, segundo Masuda, não é o oposto do trabalho e que pode ser dividido em três partes: lazer (descanso e diversão), aprendizado (estudo, hobbies, artes) e preparação para uma vida melhor em sociedade. Mas existe um lado sombrio deste chamado "tempo livre". Um impacto que representa um lado negativo da automação: o desemprego. "Há boas razões para se temer que o desemprego [...], bem como a obsolescência de velhas técnicas em função da automação, venham causar sérios problemas sociais" (MASUDA, 1980, pp. 81-82).

Para Masuda, com o aumento do tempo livre o desemprego em massa será inevitável, obrigando a sociedade da informação a enfrentar esta nova e dura realidade.

De acordo com Masuda, a inovação sistêmica por vir àquela época [grifo nosso] promoveria o surgimento de novos sistemas socioeconômicos, sendo que a "transformação do sistema educacional era a mais dramática transformação social". Nesse contexto, a primeira transformação necessária seria liberar a educação das restrições das escolas formais. "O atual ambiente educacional fechado será substituído por um ambiente educacional aberto, composto de redes de conhecimento". Já a "segunda transformação será a introdução de um tipo de educação pessoal, adequado às habilidades de cada indivíduo, substituindo o tradicional sistema uniforme de educação coletiva por um sistema determinado pela habilidade e escolha individual" (MASUDA, 1980, p.86).

Além dos dois pontos anteriores, Masuda acrescenta outros três pontos importantes, quanto às mudanças da educação: $3^{\circ}$ - o sistema de auto ensino se tornará a principal forma de educação; $4^{\circ}$ - o desenvolvimento de uma sociedade do conhecimento irá exigir que a educação seja criadora de conhecimento; $5^{\circ}$ - a educação será por toda a vida, para permitir que as pessoas possam se adaptar às mudanças da sociedade da informação (MASUDA, 1980, p.87).

Outro autor escolhido para este recorte temporal, e que ilustra a destacada transição da era industrial para a era da informação, ou do conhecimento, é o escritor John Naisbitt, que em 1982 escreveu o livro intitulado: "Megatendências - as dez grandes transformações ocorrendo na sociedade".

Neste livro, logo em seu primeiro capítulo, o autor aponta que entre as dez principais mudanças que ocorriam naquele período, "nenhuma é mais sutil, e mais explosiva, [...] que a 
megamudança de uma sociedade industrial para uma sociedade de informação" (NAISBITT, 1983, p.11).

Para Naisbitt, a sociedade de informação teve seu início entre 1956 e 1957. Em 1956, nos Estados Unidos, pela primeira vez os trabalhadores em posições técnicas administrativas e de escritório, ultrapassam o número de trabalhadores industriais, demonstrando que a maior parte dos norte-americanos trabalhava mais com informação do que com a produção de bens. No ano seguinte, em 1957, o lançamento do satélite artificial Sputinik, pelos soviéticos, marca o início da era da comunicação global por satélite, fazendo com que a Terra se voltasse para dentro de si mesma, por meio do aumento da comunicação (NAISBITT, 1983, p.12).

Para o autor, "agora ficou claro que a sociedade pós-industrial é a sociedade da informação", pois os EUA passaram a ser uma sociedade que não é mais baseada na indústria, mas na produção e distribuição de informação (NAISBITT, 1983, p.13).

Assim como Toffler e Masuda, Naisbitt afirma que:

A reestruturação [...], de uma sociedade industrial para uma sociedade de informação, será, tranquilamente, uma mudança tão profunda quanto a mudança da sociedade agrícola para a industrial. Mas com uma diferença importante. Enquanto a mudança da sociedade agrícola para a industrial levou cem anos, a reestruturação atual, da sociedade industrial para a de informação levou apenas duas décadas. A mudança ocorre tão rapidamente que não há tempo de reagir (NAISBITT, 1983, pp.17-18).

Naisbitt indica cinco pontos como principais para o entendimento do fenômeno:

a sociedade da informação é uma realidade econômica e não uma abstração intelectual; as inovações nas comunicações e na tecnologia de computadores acelerarão o ritmo da mudança, encolhendo o tempo de transmissão das informações; as novas tecnologias da informação serão aplicadas primeiro em antigas tarefas industriais, depois, gradualmente, gerarão novas atividades, processos e produtos; numa sociedade muito letrada, onde os conhecimentos básicos de ler e escrever são mais necessários que nunca, nosso sistema educacional se deteriora cada vez mais, formando pessoas cada vez menos preparadas; a tecnologia da nova era de informação não é absoluta. Dará certo ou fracassará de acordo com o princípio de alta tecnologia / grande contato humano" (NAISBITT, 1983, p.19). 
Adicionando alguns elementos aos já expostos por seus predecessores, Peter Drucker, considerado um dos pais da administração moderna publica, publica em 1993, o seu livro: “Sociedade Pós-Capitalista”. Para Drucker, a sociedade pós-capitalista é aquela que passava a ser vivenciada pelos países desenvolvidos do ocidente, que teve seu início pouco depois da Segunda Guerra Mundial, mas que, "somente com o colapso do marxismo como ideologia e do comunismo como sistema, que ficou completamente claro o fato de já termos entrado em uma sociedade nova e diferente" (DRUCKER, 1993, p. xv).

Na nova sociedade, segundo Drucker, o recurso econômico básico - os meios de produção - não é mais o capital, nem os recursos naturais (terra), nem a mão-de obra. Ele é e será o conhecimento. Para Drucker, hoje o valor é criado pela produtividade e pela inovação e que, os principais grupos da sociedade do conhecimento serão os trabalhadores do conhecimento, enquanto que os de segunda classe serão os trabalhadores em serviços (DRUCKER, 1993, p. xvii).

Ainda segundo Drucker, a mão-de-obra nas sociedades desenvolvidas não é mais um ativo, mas sim um passivo, em razão do aumento da produtividade obtida em diversos ramos da indústria. Fato este que pode promover a destruição da base industrial de um país, segundo alguns críticos, embora no Japão, com uma força de trabalho extremamente bem qualificada, o encolhimento dos empregos em manufatura seria uma resposta positiva e não um problema. O Japão, segundo o autor, considera mais produtivo investir dinheiro para que seu sistema de ensino assegure que seus jovens se qualifiquem para o trabalho do conhecimento, ou, no mínimo, serviços de alto nível (DRUCKER, 1993, pp. 43-45).

\footnotetext{
Isso irá criar tremendos problemas para os países em desenvolvimento. Eles não podem mais esperar obter grandes números de empregos em manufatura através do treinamento do pessoal com salários baixos. $\mathrm{O}$ trabalho manual, por mais barato que seja, não poderá competir com o trabalho do conhecimento, por melhor remunerado que este seja. Mas isso também cria tremendos problemas para países - o melhor exemplo é o dos Estados Unidos - onde existem grandes grupos de "minorias" que estão "em desenvolvimento" e não “desenvolvidas" em suas qualificações educacionais [...] (DRUCKER, 1993, pp. 47-48).
}

Embora os autores citados pareçam fazer apologias às transformações em curso, podemos perceber que, entre estes, é dada maior ênfase aos ganhos que aos problemas causados pela transição. Mudanças na educação, no universo do trabalho e, até mesmo o desemprego gerado aparecem como simples condições acessórias aos processos de mudanças. 
No entanto, para fins desta Dissertação, precisamos nos debruçar sobre uma análise um pouco mais profunda e crítica acerca de tais mudanças, principalmente relativas ao universo do trabalho, para podermos, a partir daí, extrairmos mais elementos para nossas análises finais. E há várias formas de introduzir estas outras análises.

Podemos iniciar pelas transformações ocorridas na sociedade do trabalho com o surgimento de novas características no trabalho e, portanto, precisamos voltar a elas e analisalas mais detidamente.

Ainda em 1958, Hannah Arendt, em seu livro: “A Condição Humana” realiza uma crítica à modernidade e aos riscos desta, à vida. Logo no prólogo de sua obra, a autora também destaca o lançamento do satélite Sputnik, ocorrido em 1957, como um fato que, segundo ela, refletindo a frase de um cientista russo, seria como "o primeiro passo para libertar o homem de sua prisão na Terra".

Tal evento, portanto, transparece como uma das glórias da ciência moderna, que havia se tornado capaz de desintegrar o átomo e previr a criação de seres humanos em provetas.

Diante da constatação dos avanços da ciência moderna, Hannah Arendt já sinalizava uma de suas maiores preocupações: o advento da automação, que já se fazia realidade àquela época. A automação, conforme a promessa dos cientistas, nas décadas vindouras, esvaziaria as fábricas e libertaria a humanidade de seu fardo mais antigo e mais natural: o fardo do trabalho.

Segundo a autora,

[...] o desejo de libertação das fadigas e penas do trabalho é tão antigo quanto a história de que se tem registro. Por si, a isenção do trabalho não é novidade: já foi um dos mais arraigados privilégios de uma minoria. [...] Parece que o progresso científico e as conquistas da técnica serviram apenas para a realização de algo com que todas as eras anteriores sonharam e nenhuma pôde realizar (ARENDT, 1987, p.12).

Mas o que poderia parecer um benefício da modernidade transforma-se, de fato, em uma das maiores agruras da sociedade moderna, pois, 
[...] a era moderna trouxe consigo a glorificação teórica do trabalho e resultou na transformação de toda a sociedade, em uma sociedade operária. Assim, a realização do desejo, como sucede nos contos de fadas, chega num instante que só pode ser contraproducente. A sociedade que está para ser liberada dos grilhões do trabalho é uma sociedade de trabalhadores. [...] O que se nos depara, portanto, é a possibilidade de uma sociedade de trabalhadores sem trabalho, isto é, sem dúvida a única atividade que lhes resta. Certamente nada poderia ser pior (ARENDT, 1958:1987, pp. 12-13).

As palavras de Hannah Arendt trazem à tona uma crise que se evidenciaria, de forma mais aguda, décadas mais tarde e se arrastaria pesadamente até os nossos dias, revelando questões importantes ao debate, no qual a transição do conceito de trabalho adquire seu papel central.

O anúncio da crise e seu aprofundamento atual revelam importantes elementos de análise, em razão da centralidade do mesmo para a sociedade moderna, capitalista e calcada na industrialização. A sociedade industrial ou a sociedade do trabalho, conforme Arendt, parece agora esfacelar-se diante de nossos olhos, expondo suas contradições e revelando suas novas configurações.

No bojo desta crise anunciada, André Gorz assevera que, a crise atual, que põe fim à sociedade industrial, não é uma crise econômica, ou mesmo da sociedade. Para o autor, "é a utopia que nutre as sociedades industriais há dois séculos que se desfaz".

\footnotetext{
Quando uma utopia desmorona, é toda a circulação de valores que regulam a dinâmica social e o sentido de suas práticas que entra em crise. É esta a crise que vivemos. Prometia-nos, a utopia industrialista, que o desenvolvimento das forças produtivas e a expansão da esfera econômica liberariam a humanidade da penúria, da injustiça e do mal-estar; que lhe dariam, com o poder soberano de dominar a natureza, o poder soberano de dominar a si mesma; que fariam do trabalho a atividade demiúrgica e ao mesmo tempo autopoiética, na qual o aperfeiçoamento incomparavelmente singular, cada um seria reconhecido - direito e dever a um só tempo - como parte da emancipação de todos (GORZ, 2007, p. 20).
}

De acordo com Gorz e Arendt, a era moderna traz consigo a glorificação do trabalho, e transformou toda sociedade em uma sociedade operária - uma sociedade do trabalho.

Antes do capitalismo manufatureiro, Gorz acrescenta, não existia uma ideia de trabalhador. O trabalho como o concebemos hoje, ou seja, no sentido moderno do termo, 
distingue-se dos afazeres necessários à reprodução da vida, ou o trabalho do artista, do artesão, do trabalho doméstico. Esta diferenciação essencial faz com que a chamada sociedade industrial possa ser percebida a si mesma como uma "sociedade de trabalhadores", distinta de todas as demais que a precederam (GORZ, 2007, p.21).

Arendt acrescenta que a sociedade de trabalhadores é uma das características da era moderna, onde ocorre a supremacia da vita activa sobre a vita contemplativa.

Ou seja, com a introdução da modernidade a vita activa passa a ser promovida à posição antes ocupada pela vita contemplativa a partir das atividades de fazer e fabricar prerrogativas do homo faber. Esta questão torna-se natural, visto que foi um instrumento produzido pelo homem que é fabricante de instrumentos, que levou à revolução moderna. "De lá para cá, todo progresso científico tem tido íntima relação com o desenvolvimento cada vez mais sofisticado da manufatura de novos utensílios e instrumentos" (ARENDT, 1987, p. 308).

Com a modernidade e, portanto, a elevação da vita activa sobre a vita contemplativa, a ação humana - ou a realização do homo faber - ganham força a produtividade e a criatividade, que iriam tornar-se os mais altos ideais da era moderna.

Mas a profunda transformação do conceito de trabalho na modernidade precisará ainda ser melhor compreendido. Desde seu início, com o advento do capitalismo manufatureiro, até a sua "crise anunciada", nos dias atuais.

Para entender melhor este ponto, o principal aspecto que precisamos ressaltar, mais uma vez, refere-se ao trabalho abstrato, que surge com o próprio capitalismo e confere ao trabalho, no modo de produção capitalista, um caráter único, que o difere de todas as outras formas de trabalho em todas as eras que a sucedem.

Quanto ao trabalho abstrato, Ruy Moreira assim o pondera:

O trabalho abstrato é uma presença que se afirma/declina como tendência cada vez que a economia capitalista sobe o nível técnico do processo produtivo. Nessa subida, a máquina tende a substituir a força de trabalho, reduzindo a massa de trabalhadores empregada (MOREIRA, 2016, p.58).

Ou seja, quanto maior é a presença da tecnologia, da maquinaria moderna, dos robôs e da automação, menor será a presença do trabalhador e, portanto, do trabalho vivo no processo 
produtivo, provocando, por sua vez, o aumento da presença do trabalho morto, que é o trabalho realizado no passado e existente no maquinário, nos robôs, etc.

O trabalho morto será, nesse processo contínuo de produção ampliada do capital, buscado incessantemente e um fator crescente, alterando a proporção de trabalho vivo e trabalho morto, sempre em favor do aumento deste último.

A esse processo incessante Ruy Moreira irá acrescentar que, "a marcha contínua da troca significa uma eliminação tendencial do trabalho abstrato no mundo produtivo, e, por consequência também da sociedade do trabalho. Até que desapareçam” (Moreira, 2016, p.59).

Neste ponto podemos aqui retornar ao pensamento de Hannah Arendt sinalizando que a "sociedade que está para ser liberada dos grilhões do trabalho é uma sociedade de trabalhadores que ficarão sem trabalho e que, certamente, nada poderia ser pior" (ARENDT, 1958:1987, pp. 12-13).

A crise incessante da sociedade do trabalho irá propiciar o fenômeno da redução dos postos de trabalho, principalmente do chamado trabalho produtivo, ou seja, daquele produtor da produção, realizador de mercadorias e, por outro lado, tende a produzir um aumento relativo do trabalho improdutivo, aquele que não produz diretamente, mas que está associado ao processo produtivo e contribui para o aumento deste. Neste ponto falamos do tipo de trabalho de escritório ou de serviços, que corroboram com o aumento da produção mesmo sem atuar diretamente nas máquinas, nas linhas produtivas.

Essa "realocação dos centros de referência", nos dizeres de Ruy Moreira, faz com que a fábrica, o mundo fabril e a produção percam importância no mundo do trabalho em prol das atividades improdutivas do setor terciário e dos serviços mais diversos.

Para Ruy Moreira, nesse ponto, "a homogeneidade do trabalho produtivo-abstrato dá lugar à heterogeneidade do trabalho de múltiplos aspectos. $\mathrm{O}$ trabalho produtor de bens passa a dividir com o trabalho gerador de serviços o universo do trabalho" (MOREIRA, 2016, p. 59).

Em resumo, a força de trabalho durante a Era Industrial apresentava-se de forma mais homogênea, sendo caracterizada em sua maioria como produtora de mercadorias.

Neste período podemos ainda estabelecer a divisão entre dois grupos de trabalhadores, com acentuadas diferenças em suas características: a) as formas de trabalho produtora de 
bens, composta por operários industriais; b) as formas de trabalho geradoras de serviços, composta por uma menor quantidade de pessoas atuando em postos de trabalho no setor terciário e em menor número que os operários industriais.

Já na chamada era pós-industrial, evidenciada pelos autores supracitados há uma força de trabalho heterogênea, predominantemente desenvolvedora de serviços e conhecimento. Com isso, há uma recomposição do quadro inicialmente apresentado e os trabalhadores passam a ser considerados, grosso modo, da seguinte maneira: a) os produtores de mercadorias, que enfrentam uma redução acentuada na quantidade de postos de trabalho; b) os trabalhadores em serviços, que podem ser considerados como produtores da produção, que encontram uma expansão relativa de postos de trabalho.

Neste novo período, os trabalhadores em serviços se ampliam para aumentar a produção de mercadorias. Ou seja, a segunda parte da força de trabalho heterogênea surge para ampliar a produção e reduzir o trabalho da primeira.

Este fato pode, em partes, explicar o porquê de os trabalhadores em serviços propiciarem uma melhoria dos processos, com a eliminação de desperdícios e novos arranjos produtivos, que irão promover exatamente a redução de tempo de trabalho ao mínimo necessário, conforme se vê atualmente em curso, pois, segundo André Gorz, "as sociedades industrializadas produzem quantidades crescentes de riquezas com quantidades decrescentes de trabalho" (GORZ, 2007, p. 94).

Em resumo, a contradição inerente ao modo de produção capitalista vem promovendo uma transformação no interior da sociedade do trabalho, que culmina com sua crise mais aguda nos dias atuais.

O trabalho abstrato, cada vez mais necessário à geração do capital, torna o trabalho concreto cada vez menos necessário, em razão da crença no progresso tecnológico.

Estas mudanças ocorrem exatamente no interior da produção, nas fábricas, que perdem centralidade na sociedade capitalista, enquanto se observa um aumento relativo do trabalho em serviços. O trabalho produtivo das fábricas, portanto, perde lugar para o trabalho improdutivo dos serviços, sendo este variado, heterogêneo e organizado para aumentar a produtividade do trabalho fabril. 
Ainda quanto à conceituação entre trabalho produtivo e trabalho improdutivo, nos dias atuais, é importante tecer mais algumas considerações.

Embora para muitos, o trabalho produtivo refira-se exclusivamente ao trabalho agrícola e industrial, que transformam a matéria prima em novos produtos e adicionam novo valor ao capital e produzem a mais-valia, devemos acrescentar que esta interpretação não é unânime no meio acadêmico.

No atual debate sobre as transformações do trabalho, alguns autores questionam a condição de materialidade para a produção de valor e mais-valia, principalmente, quando o avanço tecnológico e a nova divisão social do trabalho se fazem de forma tão intensas.

Entre esses autores podemos destacar a contribuição de Dal Rosso (2014), que analisa e discute a possibilidade da geração de valor para as atividades em serviço. $\mathrm{O}$ autor reanalisa a questão da materialidade e imaterialidade, bem como a noção de trabalho produtivo e trabalho improdutivo, para então promover a discussão da existência de trabalho produtivo no setor de serviços.

Dal Rosso inicia a discussão do tema a partir da nova divisão social do trabalho e seu papel na composição da atual força de trabalho empregada no mundo capitalista, que concentra grande percentual de trabalhadores no setor terciário (serviços), em detrimento dos setores primário e secundário. No Brasil, os dados do IBGE (2000), por exemplo, apontam que $59,8 \%$ da população encontrava-se empregada no setor de serviços, $18,7 \%$, agricultura e na indústria, 21,4\% (DAL ROSSO, 2014, p. 76).

À luz desta nova composição do emprego da força de trabalho e da nova recomposição do trabalho no mundo capitalista, o autor promove uma reflexão sobre a teoria do valor trabalho no mundo atual.

Retomando à obra de Marx, Dal Rosso analisa o chamado capítulo VI, inédito do Volume I de O Capital, que trata do trabalho produtivo e não produtivo. Neste capítulo, para Marx: "é produtivo o trabalhador que executa o trabalho produtivo, e é produtivo o trabalho que gera diretamente mais-valia, isto é, que valoriza o capital”. Outro aspecto trazido à tona por Marx, neste mesmo capítulo é que não basta ser trabalho assalariado para ser trabalho produtivo, ou seja, em princípio, nem todo trabalho assalariado é produtor de valor e de mais valia, e que o trabalho em atividade de serviços em geral é uma relação entre trabalho trocado por dinheiro e não trabalho trocado por capital e permanecem no nível de valores de uso. São 
consumidos como valores de uso e não como valores de troca e, portanto, não poderiam ser considerados trabalhos produtivos (DAL ROSSO, 2014, p. 81).

Quanto a isso, Dal Rosso destaca um amplo espaço para discussão, já que a argumentação de Marx limita-se ao contexto da Inglaterra daquele período, quando muitas atividades da medicina, da odontologia, das engenharias, o trabalho dos químicos, dos biólogos, dos advogados não haviam sido proletarizadas. Já nos dias atuais, importante parcela dessas atividades é exercida por empresas capitalistas, que almejam a valorização do capital por meio desses serviços. Nestas condições tais atividades valorizam o capital e criam mais-valia (DAL ROSSO, 2014, pp. 81-82).

Como podemos perceber as transformações do trabalho reacendem o debate acadêmico e trazem à tona interpretações e reinterpretações variadas da teoria do valor trabalho e suas categorias de análise.

Além disso, neste contexto de transformações entre a Era Industrial e a Era do Conhecimento encontramos espaço para inúmeras reflexões teóricas, inclusive para a negação da própria teoria do valor trabalho e sua capacidade de interpretação da sociedade conforme veremos a seguir. 


\subsection{A perda de referencial do trabalho como norteador da vida}

As profundas transformações do trabalho parecem por fim ao modelo de organização do trabalho existente desde o início da Revolução Industrial. E, conforme sentencia Andre Gorz,

[...] a 'sociedade do trabalho', portanto, caducou: o trabalho não pode mais servir de fundamento à integração social. Para mascarar esses fatos, é preciso, contudo, encontrar outras explicações à ascensão do desemprego e dos empregos precários. Então se dirá que desempregados e trabalhadores em situação precária de fato não procuram trabalho, que não têm aptidões profissionais suficientes e são levados à preguiça pelas excessivamente generosas indenizações de desemprego, etc. Ainda se dirá que esta gente recebe salários elevados demais para o pouco que sabem fazer, de maneira que a economia, vergada sob o peso de encargos excessivos, não tem mais o dinamismo necessário para criar mais empregos (GORZ, 2007, p. 75).

Além de Gorz, outros autores observaram as transformações em curso e a crise do trabalho, passando a questionar as bases teóricas e os modelos de estudo vigentes. Um desses autores é o sociólogo alemão Claus Offe.

Offe, em seu livro: "Trabalho e sociedade" traz a ideia de que para "as tradições clássicas da sociologia marxista ou burguesa, o trabalho seria o dado social central", e que "a sociedade e sua dinâmica são constituídas enquanto sociedade do trabalho" (OFFE, 1989, p. $13)$.

Segundo o autor, durante a era industrial e com a formulação da teoria do valortrabalho, o trabalho surge como um fato central da sociedade capitalista, por um longo período de tempo, que vai desde a Revolução Industrial, até o final da $1^{a}$ guerra mundial.

O modelo de uma sociedade burguesa voltada para a atividade econômica, dedicada ao trabalho, impulsionada por sua racionalidade e abalada por conflitos trabalhistas, é o centro das pesquisas de Marx, Weber e Durkheim - configurando uma clara identidade, apesar das divergências na abordagem metodológica e nos resultados teóricos" (OFFE, 1989, p. 14).

Neste período ocorre a imposição de uma noção de trabalho que se insere como "pedra fundamental da sociedade" em razão de alguns aspectos bem definidos, como o rompimento com o trabalho servil e o estabelecimento do trabalho assalariado. 
Este novo tipo de trabalho surge no momento em que o trabalho é arrancado da esfera doméstica e se subordina à esfera pública, em um momento em que ocorre o surgimento de uma força de trabalho, que é adaptada às condições da nova racionalidade econômica, imposta pela organização capitalista. Este novo tipo de trabalho, por sua vez, será inserido em uma divisão do trabalho, racionalizado, alienado e pauperizado (OFFE, 1989, pp. 14-16).

Essas considerações iniciais se fazem importante, pois, embora reconheçamos que toda sociedade é forçada a realizar, por meio do trabalho de seus integrantes, uma "troca metabólica" com os elementos da natureza para alcançar sua sobrevivência, apenas no período moderno, por meio da reorganização da sociedade sob o modo de produção capitalista é que vamos entender o trabalho como uma posição central na configuração da sociedade.

Por meio dessa constatação fica claro perceber a importância das características do trabalho durante um longo período de tempo, bem como as marcas deixadas, que consagraram o que costumamos chamar de sociedade industrial ou sociedade do trabalho.

Mas a despeito das fortes marcas deixadas, as mudanças tecnológicas e a consequente transição da era industrial para a era do conhecimento vêm provocando uma forte transformação no trabalho e na forma como este se realiza.

Para Claus Offe, com as mudanças em curso, o trabalho vem se tornando menos relevante na constituição da vida das pessoas e da própria sociedade como um todo.

Assim, Offe busca iluminar o fato de que as características do trabalho no período industrial, bem como "as contradições que o comandam”, tornam-se altamente questionáveis, em razão da crise do modelo. E que, no momento atual haveria um "deslocamento do ângulo de interesse da pesquisa", que provoca inúmeras reflexões e uma série de questionamentos sobre a real situação da centralidade do trabalho nos dias de hoje,

[...] existem tais indícios de um decréscimo objetivo do poder de determinação de fatos como o trabalho, a produção e a remuneração, para a constituição da sociedade e para o desenvolvimento social como um todo? A sociedade é objetivamente menos moldada pelo fato do trabalho? A esfera da produção e do trabalho perde sua potência como determinante da estrutura e do desenvolvimento? Apesar da grande maioria da população continuar dependente da remuneração, seria possível falar que o trabalho tenha se tornado individualmente e coletivamente menos relevante - ou, por assim dizer, de uma implosão da categoria trabalho? (OFFE, 1989, p. 19). 
A partir de tais questionamentos, Offe passa a desenvolver sua tese, que corrobora por trazer à tona a ideia de que o trabalho perdeu sua centralidade no mundo atual por vários fatores.

O primeiro argumento recai sobre a atual heterogeneidade do trabalho, por meio da expansão relativa do trabalho remunerado e sua diferenciação interna, já que antes os trabalhadores eram considerados uma massa homogênea, composta por uma grande quantidade de trabalhadores industriais ou rurais produtores de mercadorias.

Com essa nova heterogeneidade, podemos observar grandes variações entre as diversas situações de trabalho, com respeito à renda, qualificação, estabilidade no emprego, carga de trabalho, possibilidade de ascensão, etc. Essa heterogeneidade ocorre a partir do surgimento da era pós-industrial, quando a maior parte de trabalho passa a ser realizada no setor de serviços, que se distingue do trabalho produtor de mercadorias, sendo este primeiro difícil de ser medido economicamente.

Com esses argumentos, segundo o autor, não poderíamos mais pensar em uma unidade racional e organizada regendo todo tipo de trabalho, pois o crescimento do trabalho em serviços controla e desenvolve o trabalho na produção, tornando-se uma espécie de "corpo estranho imprescindível", mantendo e regulando o trabalho "desafiando a própria sociedade do trabalho e seus critérios de racionalidade". Ou seja,

\footnotetext{
[...] estamos lidando hoje com uma duplicação no conceito do trabalho, com o paralelismo e a oposição de critérios de racionalidade irreconciliáveis, correspondentes aos papeis de 'produtor eficiente' e da 'manutenção efetiva', eliminando assim a univocidade do conceito do trabalho (Offe, 1989, pp. 19-26).
}

O segundo argumento, continua Offe, refere-se à continuada redução dos postos de trabalho, que já na época da redação de seu livro se fazia presente no contexto alemão. Com a redução da geração de postos de trabalho, a possibilidade do desemprego se torna maior para uma grande massa da sociedade. Com isso, no conjunto de algumas regiões, comunidades, ou mesmo, alguns mercados, a realidade do desemprego passa a ser considerada normal e deixa de ser considerada como uma "vergonha individual", sendo considerada uma questão socioeconômica. O país e sua política econômica, ou política de geração de empregos passam a ser apontados como os verdadeiros culpados pelo desemprego de milhares de pessoas. 
Com esta situação, o trabalho passa a ser visto cada vez menos como um objetivo possível de ser alcançado por uma parcela considerável da população. Soma-se ao exposto, a situação de que, desde o final da década de 1970, ao menos para o contexto alemão, "uma menor aceitação das condições físicas, psíquicas e organizacionais nas quais ele [o trabalho] se realiza" (OFFE, 1989, 30).

Offe ainda questiona se o trabalho pode continuar a ser um conceito central para modelar a sociedade, dadas as transformações em curso. Se isto for verdade não poderíamos mais denominar a sociedade atual como uma sociedade do trabalho, a consciência social não pode mais ser pensada como consciência de classe e a fábrica perde sua função de referência das relações de dominação e conflitos sociais, e mesmo o temível desemprego não seria mais um fator de indagação social.

Segundo Offe, a "grande insustentabilidade do mercado de trabalho", ou seja, a crescente incapacidade do mercado de trabalho em expandir ou mesmo manter os postos de trabalho outrora criados irá propiciar à população excluída a eliminação daquelas situações de vergonha pessoal pela situação de desemprego. A grande massa de excluídos irá culpar o Estado e suas políticas econômicas, sociais e trabalhistas pela situação de marginalização.

Neste novo cenário, Offe sinaliza para a necessidade de repensarmos as teorias sociológicas que poderiam construir um arcabouço teórico que pudesse trazer luzes às novas condições pelas quais se transforma o chamado mundo do trabalho, pelas quais, segundo o autor, “os resquícios de 'ortodoxia' marxista praticamente não têm qualquer chance academicamente respeitável” (OFFE, 1989, pp. 33-34).

Offe ainda assevera que Habermas, em sua "Teoria da ação comunicativa" aponta para uma proposta teórica fundamentada na história da teoria social, "afastando-se decidida e controversamente dos paradigmas da teoria dos conflitos", analisando a "sociedade moderna não como um antagonismo autoenraizado na esfera da produção, mas como a colisão entre os 'subsistemas da ação objetivamente racional', mediatizados pelo dinheiro e pelo poder, e um 'espaço vital' autodeterminado pelo outro lado" (OFFE, 1989, p.34).

Segundo o autor, para funcionar o mercado de trabalho terá que lidar com a questão da 'distribuição dos ganhos' para os que 'trabalham' e para os que 'não trabalham'. Sendo que esta constituição distributiva dos ganhos assegura a "característica central dos sistemas capitalistas de economia de mercado" (OFFE, 1989, p.84). 
Quando o mercado de trabalho perde a capacidade de lidar com sua dupla tarefa de distribuir os frutos advindos dos processos de produção entre os que trabalham e os que não trabalham podemos entender que se estabelece uma crise do modelo.

Segundo Offe, o mercado de trabalho:

[...] é apenas limitadamente eficaz enquanto princípio de alocação da força de trabalho, e que no futuro previsível, com o desenvolvimento econômico, social e tecnológico, ele dificilmente estaria em condições de firmar-se como princípio de resolução desse duplo problema de alocação (OFFE, 1989, p. 84).

Mas o fator mais relevante a ser discutido refere-se ao conjunto de disfunções recentes no mercado de trabalho. Desde os anos 1970 encerrou-se um ciclo de expansão econômica iniciado com o fim da Segunda Guerra Mundial, pelo fim do Keynesianismo, pelos limites do crescimento e pela erosão da ética do trabalho. Soma-se a isso o aumento da natalidade da população mundial nos últimos cinquenta anos, que elevou a quantidade de trabalhadores no mercado de trabalho, que esbarram no aumento da produtividade, "com a consequência de que a força de trabalho liberada pelo progresso técnico não mais pode ser absorvida pela expansão da produção. [...] A mudança técnica torna-se assim a fonte imanente e sistêmica do desemprego" (OFFE, 1989, pp. 90-92).

Para uma parcela crescente da população, o trabalho profissional não é mais o centro de suas referências de vida. Fato este também provocado pelos seguintes aspectos: a) aumento das cobranças no trabalho; b) os papéis profissionais se empobrecem; c) os salários diminuem; d) a pressão social diminuiu para aqueles que desejam se manter alheios ao mercado de trabalho. Diante do atual cenário, portanto, vemos que nos dias de hoje o mercado de trabalho não consegue mais solucionar os problemas de produção e distribuição sociais e seu modelo encontra-se "historicamente exaurido" (OFFE, 1989, pp. 93-95).

Diante deste esfacelamento e, consequentemente perda de referencia do trabalho, o autor sinaliza para um conjunto de estratégias que são comumente adotadas por atores hegemônicos na ânsia de diminuir as pressões no mercado de trabalho.

Entre as estratégias de superação da crise atual, Claus Offe distingue quatro grandes grupos de ações realizadas pelos diferentes atores presentes nesse mercado: 1) Em primeiro lugar o autor distingue as estratégias conservadoras ou liberais, com a velha reativação da pressão de adaptação sobre a força de trabalho individual, desmontando o poder sindical e as 
políticas sociais, promovendo a redução dos custos com salários e o fortalecimento da capacidade de investimento do capital; 2) Em segundo lugar, a constitucionalização das relações de emprego, que representam a ideia básica das políticas sociais tradicionais visando alocar no mercado de trabalho pessoas excluídas, por doença ou desemprego, a partir da transferência ou seguros públicos; 3) Em terceiro lugar, a constitucionalização das políticas de emprego, onde ocorre certo comprometimento da política econômica estatal com metas de pleno emprego, e o poder público adquire certa responsabilidade pela criação de empregos, contribuindo inclusive com certa dose de paz social; 4) Em quarto lugar, surgem as ações de construção ou licenciamento de formas de atividade situadas fora do mercado de trabalho, como por exemplo, o trabalho realizado no domicílio, atividades econômicas autônomas, entre inúmeras outras (OFFE, 1989, pp. 97-107).

Na prática, embora cada uma dessas ações demonstre um pequeno sucesso aparente, em um ou outro mercado de trabalho em particular, o que se observa, em uma análise mais ampla é que todas as iniciativas citadas pelo autor não passam de paliativos. Pois, como já citado anteriormente, a questão maior da crise da sociedade do trabalho reside no problema estrutural do próprio capital, na oferta e na demanda (capital x trabalho) e nas constantes mudanças tecnológicas, promovendo a necessidade cada vez menor do trabalho humano.

Mas retornando às estratégias citadas pelo autor, observamos que estas são continuamente utilizadas, em conjunto ou individualmente e de forma generalizada nos diferentes níveis: local, regional ou nacional, para dar conta de certas tensões sociais e mascarar a iminente atrofia do mercado de trabalho e de sua capacidade de distribuir os ganhos.

Nesta constante tentativa de amainar o problema, grupos de interesse promovem leis e discursos ideológicos, que tentam conter, ao menos de forma parcial, os desajustes do modelo e promover, mesmo que de forma aparente, cenários de expansão do emprego.

Mas enquanto Offe centra o foco na perda de poder do trabalho enquanto elemento estruturante da sociedade, e na observação das estratégias de grupos dominantes para tentar contornar a crise eminente, outros autores preocupam-se em estudar as transformações do trabalho (ou o que restou dele), dando ênfase nas condições e na qualidade do trabalho existente, centralizando suas atenções para o aumento da precarização de uma quantidade cada vez maior pessoas, que vivem exclusivamente da venda de sua força de trabalho. 
Em razão de nossos estudos esta outra possibilidade de análise parece-nos muito interessante e, portanto, vamos à busca de outras reflexões. 


\subsection{O trabalho hoje: a precarização como saída para a crise do capital}

Como dissemos anteriormente, embora alguns autores apregoem a tese da perda da importância do trabalho como norteador da sociedade e até mesmo o fim do trabalho, outros autores centram foco em um sentido oposto.

Ou seja, muitos autores acreditam que, embora transformado, o papel do trabalho na composição da sociedade ainda é muito importante, em razão de que é crescente a parcela de seres humanos que, despossuídos de tudo, vivem unicamente do trabalho e também porque as transformações do trabalho são intensas nas últimas décadas e requerem esforços de entendimento especiais.

Um dos autores que caminham nessa direção e que centram seus estudos nas características do trabalho nos dia atuais é o sociólogo Ricardo Antunes.

Em seu livro: "Os sentidos do trabalho", Antunes discute as questões relativas ao trabalho na transição entre os séculos XX e XXI, bem como as transformações e centralidades do trabalho nos dias atuais. Entre outros aspectos, Antunes preocupa-se com a situação do proletariado atual (no século XXI), que por certo é muito diferente do proletariado do século XIX.

Discutindo as diferenças, mas também as semelhanças referentes ao proletariado nos dois períodos, Antunes propõe uma visão contrária àqueles que tentam impor uma ideia de que o proletariado acabou. Segundo o autor, ao contrário do que nos pretendem fazer perceber, ainda vivemos em um mundo onde se amplia a quantidade de pessoas que vivem unicamente da venda de sua força de trabalho. Com isso, Antunes propõe uma análise na busca por compreender o que podemos chamar de proletários no mundo de hoje.

Ao tentar entender o que é a classe trabalhadora hoje, Antunes deixa claro que não entende os trabalhadores ou proletários (apresentados aqui como sinônimos) como exclusivamente o proletário industrial, mas sim "homens e mulheres que vivem da venda de sua força de trabalho e que são despossuídos dos meios de produção" (ANTUNES, 1999, p. 196).

Antunes reforça que essa definição marxista parece pertinente para pensar a classe trabalhadora hoje, e que esta é composta pelos trabalhadores produtivos das indústrias, mas 
que também engloba o conjunto dos trabalhadores improdutivos, que envolve um grande leque de assalariados do setor de serviços.

Antunes também observa que neste grande grupo de trabalhadores improdutivos em todo mundo, parte encontra-se em expansão, enquanto que outra parte encontra-se em redução, a exemplo do exposto por Jinkings sobre o trabalho bancário.

Quanto aos trabalhadores improdutivos, do setor de serviços, Antunes acrescenta que estes, embora geradores de um antivalor pertençam ao que Marx chamou de falsos custos, já que são absolutamente vitais para a sobrevivência do sistema capitalista. Portanto, apesar de os trabalhadores produtivos serem ainda os produtores de mais-valia, é fundamental constituir uma análise mais ampla do quadro dos trabalhadores da atualidade e tecer uma análise sobre a noção ampliada da classe trabalhadora, para se contrapor aos críticos do "fim do trabalho" e da classe trabalhadora (ANTUNES, 1999, pp. 198-199).

Além do crescimento do trabalho em serviços, Antunes procura ampliar o entendimento do trabalho na sociedade atual, para o qual, ressalta que,

[...] a sociedade capitalista moderna vem ampliando enormemente o contingente de homens e mulheres subcontratados, terceirizados, part-time, exercendo trabalhos temporários, entre tantas outras formas assemelhadas de informalização do trabalho, que proliferam em todas as partes do mundo. Das trabalhadoras de telemarketing aos motoboys, dos jovens trabalhadores do McDonald's aos digitadores do setor bancário, os quais, Ursula Huws (2003), sugestivamente denominou como cybertariat, o novo proletário da era da cibernética (ANTUNES, 2005, p.7).

Uma noção ampliada é fundamental para a compreensão da classe trabalhadora hoje, que inclui, além do proletariado industrial e rural, os assalariados do setor de serviços. A esses últimos podemos acrescentar aqueles inseridos nos bancos, no comércio, nos serviços públicos, no turismo, etc., que se constituem em geral, num segmento assalariado em expansão no capitalismo contemporâneo (ANTUNES, 1999, pp. 102-103).

Por outro lado, quando falamos do aumento de postos de trabalho no setor de serviços precisamos frisar a relatividade deste aumento, em razão mesmo do avanço da tecnologia inclusive nos processos administrativos. Ou seja, o escritório também será absorvido pela tecnologia da informação, e a automação dos processos ceifará muitos postos de trabalho também por lá. 
Um bom exemplo desta realidade é o trabalho de Nise Jinkings: "Trabalho e resistência na fonte misteriosa: os bancários no mundo da eletrônica e do dinheiro" (2002), que traz um estudo, que procura ressaltar as transformações do trabalho nos bancos comerciais atuantes no Brasil no período entre o final do século XX e o início do século atual, bem como mostrar com estas transformações alteraram substancialmente as formas de trabalho e o total da força de trabalho absorvida pela atividade.

Baseada em dados da FEBRABAN, a autora observa que, no início da década de 1990 o setor empregava cerca de 815 mil trabalhadores e que, no final da década esse número já era de pouco mais de 400 mil trabalhadores. No mesmo período, observa a autora, o número de escriturários e operadores de caixas é reduzido, enquanto que o número de operadores de serviços telefônicos tem um expressivo aumento, em conjunto com o expressivo aumento do número de unidades de atendimento eletrônico. Ao mesmo tempo a automação bancária produziu uma elevação nas operações eletrônicas por meio de cartões de crédito e a diminuição das compensações de cheques no formato manual.

De acordo com dados do Dieese (1994), a autora sinaliza que a proporção de trabalhadores bancários na população em idade ativa (PIA) era de 2,7\% em 1985 e passou a ser de 1,8\% em 1993, graças ao aumento da técnica, redução do trabalho físico e modificação do perfil profissional do bancário e suas condições de trabalho.

De acordo com a autora,

[...] processos de automatização e de flexibilização do trabalho são implementados nos ambientes produtivos em perfeita coerência com o objetivo "determinante, predominante e avassalador" de autovalorização do capital, permitindo um aumento brutal da produtividade do trabalho e, ao mesmo tempo, gerando grandes excedentes da força de trabalho (JINKINGS, 2000, p. 103).

Além do exemplo da redução do trabalho bancário, quando falamos sobre as condições do trabalho no momento atual do capitalismo financeiro há uma importante contribuição na obra de David Harvey.

Harvey, em seu livro "O enigma do capital”, em especial no capítulo 3: "O capital vai ao trabalho" apresenta muitos casos e situações de embates entre Capital e Trabalho, como a inserção da mão de obra chinesa, e de outros países asiáticos, o colapso do comunismo, que condicionou a entrada de milhares de trabalhadores da Europa Oriental, o trabalho de 
imigrantes, o trabalho feminino, a precarização e muitas outras formas de degradação humana estão presentes hoje, quando analisamos o mundo do trabalho neste início de século XXI.

A necessidade da manutenção do crescimento do "exército industrial de reserva" é uma condição necessária para manter os salários baixos, pois o aumento da demanda e a absorção integral da força de trabalho serão prejudiciais para o capital, pois a "escassez de trabalho significa aumento dos salários" (HARVEY, 2011, p. 56).

É com este sentido que o aumento da tecnologia e as transformações nos processos produtivos tiveram a capacidade de devolver uma considerável massa de trabalhadores ao exército industrial de reserva, contribuindo para a tendência à redução dos salários.

Para Harvey, este quadro tem promovido a mobilização do capital e do trabalho produzindo uma situação muito confortável para o capital, em relação ao trabalho. "As reservas de trabalho existem em toda parte e há poucas barreiras geográficas ao acesso capitalista. [...] Mas hoje em dia o principal problema reside no fato de o capital ser muito poderoso e o trabalho muito fraco, não o contrário" (HARVEY, 2011, p. 61).

A origem dessa situação inicia-se, segundo Harvey, na virada dos anos 1980 para 1990, com a introdução das políticas Neoliberais e o colapso das políticas de Welfare State vindo a ser complementadas pela inserção de maciços contingentes de trabalhadores chineses e também asiáticos, como já foi dito.

Além do afluxo de um adicional de mão-de-obra, Harvey assevera que é fundamental para o capitalismo manter a continuidade dos fluxos de capital visando sua ampliação continuada. Quando há restrições a estes fluxos, o capital se depara com problemas estruturais ou crises, que tendem a ser contornadas, de um jeito ou de outro.

Uma das formas de reverter esses estrangulamentos dos fluxos do capital diz respeito ao uso da tecnologia na produção ou nas cadeias de fornecimento, que cumprem um duplo papel, pois além de facilitar os fluxos reduzem a necessidade de empregos, ampliando o Exército Industrial de Reserva.

Quanto ao enorme contingente de trabalhadores chineses, tão propalados como um dos fatores do atual estado da força de trabalho mundial é elucidante a passagem sobre o assunto no livro de Arrighi: “Adam Smith em Pequim: origens e fundamentos do século XXI” (2008).

Neste livro, discorrendo sobre a origem e dinâmica da ascensão chinesa, Arrighi argumenta que não foi apenas a imensa quantidade de reserva de mão-de-obra barata, já que 
há muitas reservas pelo mundo afora. O que o autor destaca é a "qualidade desta reserva de mão-de-obra em termos de saúde, educação e capacidade de autogerenciamento, combinada à expansão rápida das condições de oferta e demanda para a mobilização produtiva dessa reserva dentro da própria China". Essa combinação, todavia, acrescenta o autor, não foi criada pelo capital estrangeiro, mas por um processo interno de desenvolvimento, vindo a receber posteriormente aporte de capital estrangeiro, sustentando-o ou minando-o em certos casos (ARRIGHI, 2008, p. 357).

Ainda segundo Arrighi, embora se fale muito no investimento estrangeiro no país, que saltou de 20 bilhões de dólares na década de 1980, para 200 bilhões em 2000, chegando a 450 bilhões, nos três anos seguintes, ele somente ocorreu porque a China investiu ainda mais. "Em outras palavras, o capital estrangeiro aproveitou o bonde da expansão econômica, que não foi ele que iniciou, nem liderou" (ARRIGHI, 2008, p. 359).

Em meio a este conjunto de processos e práticas do capital que direcionam a força de trabalho, a fim de facilitar os fluxos do capital é importante analisarmos um pouco desses processos no Brasil.

Quanto a isso é importante a visão de conjunto trazida por Milton Santos e Maria Laura da Silveira no livro: “O Brasil: território e sociedade no início do século XXI". Nesta obra os autores centram suas análises na presença de um meio-técnico-científicoinformacional que passa a estabelecer uma nova divisão territorial do trabalho, recriando uma hierarquia entre lugares, e redefine a capacidade de agir das pessoas, das firmas e das instituições, com uma clara expressão geográfica da globalização no país, promovendo a criação de regiões do mandar e regiões do fazer, ou seja, a divisão e a especialização do trabalho nos lugares (SANTOS; SILVEIRA, 2002, pp. 21 e 22).

Santos e Silveira apontam que, na virada para o século XXI, o país apresenta uma reorganização produtiva do território "graças aos progressos da ciência e da técnica e à circulação acelerada de informações, [que] geram as condições materiais e imateriais para aumentar a especialização do trabalho nos lugares”. Amplia-se a descentralização da indústria e despontam novos fronts no comércio e em serviços, especialmente em regiões portadoras de densidade técnica, como a chamada Região Concentrada do Brasil, na definição do próprio Milton Santos (SANTOS; SILVEIRA, 2002, p. 105).

Buscando revelar a constituição das novas dinâmicas no território brasileiro, a partir da ideia de sistemas técnicos, os autores apresentam significativas alterações na dinâmica 
espacial dos usos do território nacional, com a presença de novos vetores e novos atores, possibilitando uma interpretação geográfica numa visão de conjunto, um retrato de novas "quantidades e, sobretudo das novas qualidades do território que, vistas de maneira dinâmica" permitem vislumbrar as tendências do uso do espaço geográfico (SANTOS; SILVEIRA, 2002, p. 12).

Dentre as várias tendências apontadas, destacaremos a tendência à expansão do consumo das viagens, do turismo e do lazer.

Destaca-se o aumento da chegada de turistas estrangeiros no país, que recebeu, em 1998, a quantidade de 5,53 milhões de turistas estrangeiros, dos quais dois milhões ingressaram por via aérea. Neste compasso, naquele mesmo ano, o Brasil ocupava a posição de $25^{\circ}$ lugar no ranking da Organização Mundial do Turismo - OMT. O crescimento da hotelaria se faz presente também no final do século XX, com destacada presença das capitais de estados como Belo Horizonte, Curitiba, Recife, Florianópolis, Fortaleza e Natal, além de um forte crescimento identificado nas três principais capitais do país: São Paulo, Rio de Janeiro e Brasília. A instalação de cadeias globais de hotéis também se faz importante no país, além da instalação de pequenos hotéis e pousadas. Segundo os autores, havia no Brasil, em 1980, 1.255 hotéis de todas as categorias, enquanto que em 1994 este número já atingia a cifra de 2.366 (SANTOS; SILVEIRA, 2002, p. 235).

Ainda quanto à presença de redes internacionais na hotelaria brasileira é importante o trabalho de Renata Proserpio (2007), intitulado: “O avanço das redes hoteleiras internacionais no Brasil”.

Para Prosérpio, a reanimação do setor de hospedagem no Brasil, ocorre no período entre 1994 e 2006, com a dinamização do mercado de viagens, a entrada de novos agentes, como os fundos institucionais, construtoras e incorporadoras imobiliárias, financiando novos projetos, por meio da capitalização da renda disponível e os investimentos públicos em infraestrutura turística (PRODETUR e BNDES) (PROSERPIO, 2007, p. 108).

Entre os novos agentes financiadores investidores, Prosérpio dá especial ênfase à entrada dos fundos de pensão, que passaram a investir no setor hoteleiro a partir da década de 1990, “em decorrência da dinamização do mercado de viagens, do crescimento de recursos por eles administrados e da necessidade de diversificação das inversões, até então concentradas em prédios comerciais, sobretudo os shoppings centers" [...]. O interesse dos 
fundos de pensão no setor hoteleiro se deu em virtudes de certas características do setor que ofereciam vantagens para ambos os lados:

[...] obediência à nova política das redes, segundo a qual os investimentos deveriam se concentrar na gestão, e não nos empreendimentos imobiliários, diminuindo os riscos do negócio; por outro lado, para os fundos, e demais proprietários dos imóveis, as redes ofereciam diversas vantagens, como gerenciamento profissional, tecnologias de gestão, formação de mão-de-obra, implantação de padrões básicos internacionais de qualidade de serviços, acesso as centrais de reservas e sistemas internacionais de captação de clientes próprios e identidade corporativa (PROSERPIO, 2007, p. 110).

Além disso, a centralização de atividades administrativas e outras economias de escalas garantiam melhores taxas de ocupação, maiores margem e menores riscos (PROSERPIO, 2007, pp. 110-111).

Retornando ao estudo de Santos e Silveira, os autores ainda destacam o número de agências de viagens, que, em 1996, apresenta-se com 1312 unidades, das quais 310 (23,6\%) localizavam-se em São Paulo, 270 em Minas Gerais, 106 no Rio de Janeiro e 102 no Rio Grande do Sul, além do aumento das locadoras de veículos (SANTOS; SILVEIRA, 2002, p. 236).

O destaque no aumento da prestação de serviços no país está associado ao forte aumento dos postos de trabalho no período destacado.

A esse respeito podemos utilizar os estudos de Marcio Pochmann, em especial o livro: "Nova classe média? - o trabalho na base da pirâmide social brasileira" que lança luzes sobre a mobilidade da pirâmide social brasileira no início do século XXI, afastando-se de uma "abordagem rudimentar e tendenciosa a respeito da existência de uma nova classe média" no país (POCHMANN, 2012, p. 7).

Pochmann propõe um olhar mais detalhado na geração de empregos no Brasil, destacando o aumento expressivo dos empregos de baixa remuneração, que embora tenha possibilitado um aumento da renda, estaria longe de propiciar um aumento real e consistente de uma chamada "classe média". 
Em síntese: entende-se que não se trata da emergência de uma nova classe - muito menos de uma classe média. O que há, de fato, é uma orientação alienante sem fim, orquestrada para o sequestro do debate sobre a natureza e a dinâmica das mudanças econômicas e sociais, incapaz de permitir a politização classista do fenômeno de transformação da estrutura social e sua comparação com outros períodos dinâmicos do Brasil (POCHMANN, 2012, p. 8).

O autor deixa claro que, durante a primeira década do século XXI, ocorre alteração no padrão de trabalho, com forte dinamismo de ocupações com baixa remuneração. "Do total líquido de 21 milhões de postos de trabalho criados na primeira década do século XXI, 94,8\% foram com rendimentos de até 1,5 salário mínimo mensal”, enquanto que nas ocupações sem remuneração houve redução de mais de um milhão de postos de trabalho. Já na faixa remuneratória de cinco salários mínimos a redução de postos de trabalho chegou a 4,3 milhões, provocando uma expansão "na base da pirâmide social brasileira" (POCHMANN, 2012, p. 27).

Ao final da década, em 2009, a força de trabalho era composta por $47,8 \%$ de ocupações com até 1,5 salário mínimo, responsável por 24,5\% da remuneração gerada no país e que, segundo o autor, se seguíssemos a literatura internacional deveríamos enquadrar este numeroso grupo na "categoria analítica de working poor", revelando o padrão de trabalho existente no país em decorrência do modelo macroeconômico adotado, com maior aumento de novos postos de trabalho em serviços, 6,1 milhões, seguido de trabalhadores no comércio, com 2,1 milhões, na construção civil, 2 milhões, escriturários, 1,6 milhões, indústria têxtil e vestuário, 1,3 milhão e atendimento ao público, 1,3 milhão. Ressalta-se a contratação de mulheres, que na década apresenta quase 60\% das ocupações geradas (POCHMANN, 2012, pp. 29-30).

Com relação a essas profundas transformações nas condições de trabalho do país, Ricardo Antunes acrescenta que até a década de 1980 a economia brasileira encontrava forte expansão na indústria. Porém, nas últimas décadas o setor terciário aumentou expressivamente sua posição relativa no PIB. Entre 1980 e 2008, cresceu de 30,6\% para mais de $60 \%$ da produção nacional. Essa transformação afetou fortemente a composição da força de trabalho, com significativa expansão das atividades de serviços: o trabalho nos callcenters, telemarketing, nas empresas de Tecnologia da Informação e Comunicação - TICs, "gerou o nascimento de um novo proletariado de serviços, o infoproletariado, ou o cibertariado" (ANTUNES, 2018, p. 119). 
Para Antunes, a rápida transformação da composição da força de trabalho no Brasil é a expressão de uma contradição da era atual, onde em plena era da informação o trabalho tornase "marcado pela informalização do trabalho (trabalhadores sem direitos), presente na ampliação dos terceirizados/subcontratados, flexibilizados, trabalhadores em tempo parcial, teletrabalhadores, potencializando exponencialmente o universo do trabalho precarizado" (ANTUNES, 2018, p. 120).

Essa tendência já era apontada por David Harvey, em seu livro: “A condição pósmoderna". Nesta obra, Harvey destaca as mudanças culturais, políticas e econômicas que passam a ocorrer no mundo a partir do início da década de 1970, dando ênfase à nova forma de organização do capitalismo, com novos modos flexíveis de acumulação do capital. Ações organizacionais como o just-in-time, as células de manufatura, os círculos de controle da qualidade, a produção enxuta, entre outras práticas de racionalização da produção e consequentemente da força de trabalho, associadas ao aumento da tecnologia e a robótica na linha de produção possibilitaram cada vez mais a redução do trabalho fabril, constituíram o credo dos administradores e dos investimentos no setor produtivo, tanto no Brasil, quanto em qualquer parte da economia capitalista.

Como se vê, as mudanças nos padrões produtivos e tecnológicos ampliaram as modalidades de exploração do trabalho, como a flexibilização, a informalização e o amparo de um forte aparato legal promovido pelo Estado, com a desregulamentação das leis trabalhistas.

No Brasil, com o avanço da crise mundial de 2008, durante o governo Lula, o Estado procurou incentivar a economia com a redução de impostos em setores como o automobilístico, a construção civil e a produção de eletrodomésticos, incentivando o a expansão do mercado interno e a geração de postos de trabalho. Neste período os governos Lula e Dilma aumentaram o número de trabalhadores e reduziram os índices de desemprego, "no entanto, não foram capazes de eliminar as condições de vulnerabilidade presentes no nível de informalidade, terceirização e precarização da força de trabalho" no país (ANTUNES, 2018, p. 122).

Assim, tanto no mundo, quanto no Brasil, formaram-se as condições propícias para a transformação do trabalho e, conforme podemos perceber, conferiu-se à precarização o seu novo paradigma. 
O trabalho no setor do turismo, por sua vez, não ficou imune a este fenômeno e, para ele, nossas atenções se voltarão nos capítulos seguintes. 


\section{Capítulo $2 O$ trabalho no turismo: da genealogia das práticas à criação de um novo mercado de trabalho}

Preparavam-se todos alegremente para a estação que oferecia, além do sabor da novidade, a deliciosa perspectiva dos banhos de mar! Era quase sempre em São Vicente que se alojavam, nalguma velha casa da única rua existente na vila de Martim Afonso. [...] Lá se ia toda a família a empreender a cavalo a longa viagem com grande número de escravos, mucamas e pajens, além dos tocadores dos dois banguês que transportavam as crianças.

Maria Paes de Barros, No Tempo de Dantes (1946:1998).

\section{1 - A gênese dos territórios turísticos}

Concordamos com o geógrafo suíço Claude Raffestin no primeiro capítulo de seu livro: "Por uma Geografia do Poder", que quanto mais jovens as ciências dos homens, mais tentadas elas são em estabelecer sua genealogia. Ninguém espera uma exposição histórica no início de um trabalho de física. Em contrapartida, em se tratando de sociologia, de ciência política, ou geografia, as referências a uma filiação não causam estranheza (RAFFESTIN, 1993, p. 11).

Intuitivamente, este exato sentimento tomou forma ao iniciarmos este estudo. Desde o início nos vimos tentado a buscar as origens e as primeiras iniciativas das atividades laborais, que se destinam especificamente ao turismo. Desta forma, iniciamos uma busca por materiais e elementos que contribuissem com a identificação de uma gênese deste tipo específico de trabalho.

Nosso questionamento nesse momento era o seguinte: podemos dizer que existe um mercado de trabalho formado especificamente para o turismo? Se a resposta a essa pergunta fosse afirmativa, partiríamos às demais questões: quando tal mercado de trabalho teve início? Quando e como esse mercado se formou no mundo e no Brasil?

Em uma primeira aproximação ao tema, identificamos dois trabalhos literários do século XIX, que possibilitam uma abordagem introdutória. Entre os trabalhos citamos dois expoentes da literatura mundial: a escritora inglesa Jane Austen e sua novela inacabada "Sanditon", escrita em 1817, e o mestre do Romantismo francês, o escritor Victor Hugo, com seu reconhecido livro: “Os trabalhadores do Mar”, de 1866. 
Do autor extraímos a ideia central deste capítulo, a visão da sociedade da época e as transformações socioespaciais narradas na pequena ilha de Guernsey. Na obra de Austin, escrita 49 anos antes da primeira, observamos mais detalhadamente as transformações socioespaciais ocorridas em uma vila à beira-mar, motivada por um recém-criado empreendimento turístico no início do século 19.

Tentando encontrar evidencias de tal fenômeno no Brasil, introduzimos em nosso estudo dois exemplos de literatura nacional.

O primeiro exemplo refere-se a um livro de memória, que retrata a vida na Paulicéia: "No Tempo de Dantes" (1946:1998), descrita a partir da vida de Maria Paes de Barros, representante da elite paulistana.

O outro exemplo extraído de nossa literatura refere-se ao trabalho do dramaturgo Arthur de Azevedo, que em 1897, traz ao público da cidade do Rio de Janeiro, a peça "A Capital Federal"'.

A partir da análise inicial dessas quatro obras identificamos diversos elementos que descrevem aspectos necessários à reconstituição de um tempo e um espaço, que permitem retratar, ainda que de forma introdutória, a gênese dos territórios turísticos e a criação de empreendimentos turísticos com novas formas de utilização do espaço e do trabalho, por meio de uma força de trabalho específica, voltada às necessidades de tais empreendimentos.

Neste novo ambiente discutiremos os principais aspectos relativos à transformação do espaço, aos novos usos do território e às novas relações de poder, que se conformam a partir dos locais estudados: Sanditon, Guernsey, São Paulo e Rio de Janeiro, nos respectivos períodos analisados. Os novos gostos e hábitos da burguesia, uma nova forma de ocupação do tempo e do espaço, novas e modernas tecnologias, novos e mais eficientes meios de transporte, novos negócios e as perspectivas de maiores lucros, aparentemente terão papel preponderante na consolidação dos empreendimentos turísticos e, por consequência, na forma como uma força de trabalho será mobilizada em torno destes.

Para finalizarmos este capítulo, retornaremos então à pequena ilha Guernsey de nossos dias, para a análise atual do turismo local, identificando as características principais daqueles que chamaremos de "Os 'novos' trabalhadores do mar": a força de trabalho mobilizada no consolidado setor turístico da ilha e que tanto diferem dos trabalhadores do mar, descritos na Guernsey de Victor Hugo. 


\section{2 - Sanditon: uma vila à beira mar, 1817}

A escritora Jane Austen, autora de obras primas da literatura inglesa, deixou uma obra memorável e fértil conteúdo para análise da sociedade aristocrática da época, apesar de sua morte precoce aos 42 anos. Desta grande obra, chamaremos a atenção, para fins de introdução de nosso trabalho, ao seu último e inacabado título: a novela Sanditon, iniciada em 1817, ano de sua morte.

Sanditon é o nome de uma pequena e imaginária vila à beira mar, na costa de Sussex, ao sul da Inglaterra, supostamente próxima à Brighton, uma das primeiras estações turísticas da Inglaterra.

A imaginária Sanditon surge como uma pequena vila de pescadores, que começa a ensaiar seu crescimento como um novo e florescente local da moda para os banhos de mar com finalidade terapêutica. Esta localidade imaginária, porém "muito real", nos revela detalhes interessantes e, embora inacabada, impressiona pela clareza e análise crítica.

Ao longo de poucas páginas a autora nos faz perceber de imediato as rápidas e profundas transformações impostas ao vilarejo; a especulação de proprietários sem escrúpulo; a euforia das temporadas de verão; a exploração do trabalho; a inflação dos preços; além da conhecida crítica social aos casamentos arranjados e bajulações de toda ordem.

A trama inícia-se com a viagem do casal Parker com o objetivo de persuadir médicos das redondezas a morarem em Sanditon, para que pudessem receitar, aos recém-chegados turistas, as modernas práticas da medicina vigente, que passava a prescrever os banhos de mar e períodos à beira-mar como prática terapêutica. Nesta viagem, após a quebra de sua carruagem, o Senhor Parker fere seu tornozelo e fica hospedado na casa da família Heywood, a fim de reestabelecer-se. Neste interim, Parker diz à sua esposa:

[...] E uma vez em casa, temos o nosso remédio à mão, você sabe. Um pouco de nosso próprio e revigorante ar marinho, em breve irá por me de pé novamente. Depender dele, minha querida, é exatamente um caso para o mar. Ar salino e imersão vão ser a suficientes. Minhas sensações me dizem isso já (AUSTEN, 2007, p. 4 , tradução nossa).

Adiante, Mr. Parker, em conversa com seu anfitrião, Mr. Heywood passa a discorrer sobre os novos lugarejos no litoral que crescem em popularidade: [...] "mas Sanditon em si, 
todo mundo já ouviu falar: o jovem e crescente local de banhos, certamente o local favorito dentre todos os que podem ser encontrados ao longo da costa de Sussex - a mais favorecida pela natureza, prometendo ser o local escolhido pelos homens" (AUSTEN, 2007, p.5).

O anfitrião, Mr Heywood, homem do interior, tem visão diferente de Parker sobre o novo desejo de instalar-se na costa:

Sim, eu ouvi falar de Sanditon. A cada cinco anos ouve-se falar de algum novo lugar sendo iniciado no litoral em crescente moda. Como eles conseguem lotar metade deles é a maravilha! Onde as pessoas podem ser encontradas com dinheiro e tempo para ir até esses lugares! Coisas ruins para um país, certamente aumentam os preços das provisões e fazem os pobres servirem para nada (AUSTEN, 2007, p.5, tradução nossa).

Mas o protagonista ambicioso não se dá por vencido e procura dissuadir seu anfitrião: "Nem um pouco, senhor, nem todos", gritou o Mr. Parker ansiosamente.

\begin{abstract}
Muito pelo contrário, eu lhe garanto. Uma idéia comum, mas equivocada. Pode aplicar-se a lugares crescidos como Brighton ou Worthing ou East Bourne, mas não para uma pequena aldeia como Sanditon, excluída pelo seu tamanho de experimentar qualquer um dos males da civilização. Enquanto o lugar cresce, os prédios e etc. demandam-se por tudo, certamente acomodações da melhor companhia àquelas famílias de alta classe e cheias de caráter, que são uma benção em qualquer lugar, excitam a indústria do conforto e melhoria, entre eles, de toda sorte (AUSTEN, 2007, p.5, tradução nossa).
\end{abstract}

O Senhor Parker irredutível, por motivos de interesses financeiros óbvios, procurava seduzir a todos com as qualidades do local:

Um lugar como Sanditon, senhor, posso dizer, era procurado, e foi chamado para isso. A natureza marcou este lugar [...]. A melhor e mais pura brisa do mar, reconhecida por excelentes banhos, areia fina e dura, com águas profundas há dez jardas da costa, sem lama, sem ervas daninhas, sem pedras viscosas. Nunca houve um lugar mais palpável desenhado pela natureza para ser um resort para os ‘inválidos’ (AUSTEN, 2007, pp. 5-6, tradução nossa). 
Jane Austen, em sua profunda crítica, capacita o protagonista de farto discurso e eloquência, capaz de seduzir a todos e promover o lugar com total desenvoltura. Em sua narrativa a autora assim descreve a ambos - o Senhor Parker:

[...] era visto como um entusiasta sobre o tema Sanditon, um entusiasta completo.

Sanditon, o sucesso de Sanditon como um pequeno e elegante lugar de banho, era o objeto para o qual ele parecia viver. Há uns poucos anos atrás, tinha sido uma pacata aldeia sem pretensões; mas algumas vantagens naturais em suas posições e algumas circunstâncias acidentais haviam sugerido a si mesmo, e a outra proprietária do lugar, com uma grande probabilidade de tornar-se uma especulação lucrativa, eles haviam se envolvido nesse lugar, planejado, construído, elogiado, e inchado, e o levantado para algo novo e de renome (AUSTEN, 2007, p.7, tradução nossa).

No período em que a autora desenvolve seu último trabalho, as novas práticas da medicina moderna são divulgadas de forma intensa, apregoando as vantagens e qualidades do banho de mar e do ar marinho como práticas terapêuticas. Diante de tais conhecimentos, o Senhor Parker fazia dos argumentos da medicina os seus argumentos comerciais.

Ele assegurou-se de fato como certo, que nenhuma pessoa poderia estar realmente bem, nenhuma pessoa [...] poderia estar realmente em um estado seguro e permanente de saúde sem gastar pelo menos seis semanas ao mar a cada ano. $\mathrm{O}$ ar marinho e o banho de mar juntos eram quase infalíveis, um ou outro deles seria a cura para todo tipo de doenças, transtorno do estômago, pulmões ou sangue. Eles eram antiespasmódicos, antipulmonares, antissépticos, antirreumáticos. Ninguém poderia pegar um resfriado à beira-mar; ninguém perdia o apetite à beira-mar [...]. Ar do mar ou o mar curava, suavizava, relaxava, fortificava. Por vezes um por vezes o outro. Se a brisa do mar falhasse, o banho de mar era com certeza o corretivo; e onde o banho de mar falhasse só o ar do mar era, evidentemente, projetado pela natureza para a cura (AUSTEN, 2007, p.9, tradução nossa).

É importante destacar, neste momento, que o turismo, tal como o conhecemos hoje, ou seja, como atividade organizada, inexistia naquele período. O próprio conceito de "turista" remete aos anos 1830, e é oficialmente introduzido por Stendhal ${ }^{5}$, em 1838.

Diante deste cenário de descobertas científicas e novas práticas sociais, Sanditon torna-se um local efervecente e da moda, sujeitando-se a todas as transformações que a ocasião lhe imporia. 
Com a chegada do casal Parker à sua elegante residência, a autora promove interessantes descrições sobre as características do vilarejo à beira-mar em processo de transformação.

Ele desejava estar nas areias, os rochedos e, ao mesmo tempo, em qualquer lugar em sua própria casa. Seu espírito cresceu com a simples visão do mar e ele quase podia sentir o tornozelo ficando já mais forte. Trafalgar House, no local mais elevado no baixio, era um elegante edifício, localizada em um gramado pequeno com uma plantação em volta dela, cerca de cem jardas do topo de uma íngreme, mas não muito elevada falésia e o mais próximo a ele de todos os edifícios, com exceção de uma curta fileira de casas de boa aparência chamadas de Terrace, com um largo passeio em frente, que aspira a ser o shopping-center do lugar. Nesta passagem estava a melhor loja de moda e a biblioteca, um pouco separada dele, o hotel e o quarto de bilhar. Aqui começou a descida para a praia e para as máquinas de banho. E este era, portanto, o local preferido para a beleza e a moda (AUSTEN, 2007, p.18, tradução nossa).

Como podemos perceber, na pequena Sanditon de Jane Austen, encontraremos a maior quantidade de elementos para identificar os primeiros aspectos da transformação do espaço geográfico, por meio de um uso transitório do espaço, ligado a práticas que, anos mais tarde seriam reconhecidas e denominadas como turísticas. Uma nova territorialidade expõe uma nova série de complexas relações.

5. Stendhal é o pseudônimo de Marie-Henri Beyle (1783-1842), escritor francês e autor do livro "Mémoires d'un touriste", publicado originalmente em 1838 e, segundo a historiagrafia, obra em que a palavra "turista" aparece como um neologismo. 
Em Sanditon, Mr. Parker e Lady Denham, os maiores proprietários do lugar, controlam o preço dos imóveis, dos aluguéis, das acomodações e da força de trabalho empregada. Tudo atrelado ao recente empreendimento e aos lucros, ligados à arte de receber visitantes.

A análise da obra de Jane Austin possibilita a visão de duas diferentes realidades e diferentes formas de uso do território. Destas diferenças serão especialmente interessantes as análises das relações de poder entre os diferentes atores, conformando uma nova territorialidade em curso. Podemos até mesmo pensar em uma "territorialidade do turismo", aonde aspectos econômicos, políticos, sociais e culturais irão se desdobrar de maneira peculiar, de acordo com a peculiaridade de cada localidade.

Em Sanditon, por exemplo, os fragmentos do texto de Jane Austen nos trazem revelações de um período de novas práticas, ajustadas aos novos desejos de ocupação da beira-mar.

Para o historiador francês Alain Corbin, em seu livro "O território do Vazio: a praia e o imaginário ocidental"

[...] é, em 1817, com o trabalho de Jane Austen, que pela primeira vez, a sociabilidade organizada em torno do banho de mar torna-se o objeto central de uma obra romanesca. A derrisão que a autora demonstra não se exerce apenas em relação ao discurso e às conversas banais sobre o pitoresco do mar; dirige-se também à incultura, à falta de moralidade, à estupidez dos que decidiram frequentar Sanditon; investe contra a arte burguesa do repouso, nascida do desejo de imitar os nobres e da difusão da nova sensibilidade cinestésica. Sanditon constitui a própria imagem da estação derrisória, fundada por um caçador de locatários, Mr. Parker, lastimável oportunista da obsessão da saúde. Alguns alojamentos batizados com nomes pomposos, localizados em uma modesta explanada, constituem o palco de cenas ridículas. A praia aparece aqui apenas como pano de fundo. $\mathrm{O}$ pequeno-burguês hilariante, o bonitão caçador de dotes, a dama arrivista e sem moralidade, entre outros [...] evoluem ante os olhos de uma jovem e lúcida expectadora, órfã pobre, mas invejosa da burguesia de Sussex. Nada no romance, evoca a presença de um público realmente popular (CORBAIN, 1989, p. 297).

Em nossa análise, todavia, podemos sim observar a presença de populares na narrativa, porém, sempre periféricos às passagens centrais da obra, o que perece ser o propósito da autora. Cocheiros, jardineiros, pastores, pescadores, empregadas domésticas e até as auxiliares de banho. Tais personagens, embora incógnitas no desenrolar da trama, 
aparecem tão necessárias à burguesia da época, quanto os arranjos espaciais em curso. Neste novo contexto surge o que iremos chamar de os novos trabalhadores do mar, que serão introduzidos e ajustados, ainda que de forma periférica a "um complexo feixe de novas práticas, de um novo uso do tempo e um novo arranjo do espaço, imposto pelas novas formas de sociabilização" (CORBAIN, 1989, p.266).

Este complexo feixe de novas práticas sociais engedra mudanças sobre a maneira como certos atores irão se reaproveitar do território. O território do vazio de Alain Corbain será apropriado de maneira muito específica, redefinindo e revalorizando a beira-mar: seja ela em Sanditon, Guernsey, São Paulo ou Rio de Janeiro.

Retornando à Sanditon, podemos ainda analisar a o poder exercido pelo Sr. Parker e Lady Denham, bem como suas estratégias de arranjos espaciais e a dominação da força de trabalho. Alguns relatos extraídos do texto original reforçam tal ideia.

A principal proprietária do local, Lady Denham, questiona o Mr. Parker novamente na tentativa de manter o controle sobre os trabalhadores:

Por quê? O que nós devemos fazer com um médico aqui? Isto somente encorajaria nossos empregados e aos pobres a ficarem doentes, caso tenham um doutor em mãos. Oh! Oremos, deixe-nos livre desta tribo em Sanditon. Nós estamos bem como estamos (AUSTEN, 2007, p.26, tradução nossa).

A proprietária ainda, mais à frente, expõe de forma mais dura, as diferenças sociais, com sua visão pragmática e deixa transparente sua imposição sobre os empregados e pessoas de classes sociais menos favorecidas.

[...] desde que Sanditon se tornou um lugar público, famílias e mais famílias vêm, mas, tanto quanto eu saiba, nem um em cem dentre eles têm qualquer propriedade real: herdadas ou conquistadas. Uma renda talvez, mas nenhuma propriedade. Clérigos talvez, ou advogados da cidade, ou oficiais de meia-paga, ou viúvas com apenas um dote. E que bem podem tais pessoas fazer a alguém? Exceto assumir as nossas casas vazias e, entre nós, eu acho que eles são grandes tolos por não ficar em casa. Eu não tenho nenhum gosto por ter a minha casa tão cheia quanto um hotel. Eu não devo escolher ter o tempo de minhas duas empregadas domésticas, tomado todas as manhãs na limpeza dos quartos. Eles têm quarto de Clara para arrumar, bem como o meu próprio todos os dias. Se os empregados tiverem lugares difíceis para trabalhar, eles vão querer salários mais altos (AUSTEN, 2007, p.33, tradução nossa). 
Em outra conversa, Lady Denham nos faz perceber, rapidamente, os conflitos existentes e a aguçada visão de negócios do Sr. Parker, ao demonstrar-se incomodada com a grande chegada de visitantes e o aumento dos preços na localidade: "E se eles vierem ao nosso meio para elevar o preço das nossas necessidades da vida, não devemos agradecê-los muito, Sr. Parker".

Enquanto isso, já com outra lógica, o Sr. Parker responde:

\footnotetext{
Minha querida Senhora, eles só podem aumentar o preço dos artigos de consumo em razão de uma maior demanda para eles, e tal difusão de dinheiro entre nós deve fazer-nos mais bem do que mal. Nossos açougueiros e padeiros e comerciantes em geral, não podem ficar ricos sem trazer prosperidade para nós. Se eles não ganham, nossos aluguéis se tornam inseguros; e em proporção, o lucro deles deve ser o nosso, eventualmente, no valor acrescido das nossas casas (AUSTEN, 2007, pp. 25-26, tradução nossa).
}

A propriedade da terra e dos imóveis garante a transferência dos ganhos comerciais para os proprietários do lugar, que por sua vez também se apropriam do trabalho, do qual extraem a mais-valia. Pelo exposto fica claro o projeto do Sr. Parker e Lady Denham, que embora tenham visões conflitantes sobre certos aspectos, parecem concordar com as estratégias de dominação e ganhos. Os preços dos aluguéis, os locais de investimento, o tratamento com a mão de obra e a tentativa de atrair mais e mais visitantes. Embora as ideologias e os conflitos aparecam, as relações econômicas e as relações de poder se impõem sobre o território, por meio dos ajustes espaciais e o controle sobre o trabalho. 


\section{3 - Ilha de Guernsey, 1866}

Victor Hugo, o famoso escritor francês, viveu de 1855 a 1871, um longo período de exílio, na ilha de Guernsey localizada na baia de Saint Malo, há aproximadamente 50 quilômetros da costa da Normandia e há pouco mais de 100 quilômetros da costa sul da Inglaterra. Alí, durante dezesseis anos de profícua produção literária, Victor Hugo publicou, entre outros trabalhos, sua maior obra "Os miseráveis", em 1862.

Neste mesmo período, também escreveu, no ano de 1866, um de seus romances mais conhecidos "Os trabalhadores do mar". Nesta obra, o autor dedica um de seus maiores trabalhos ao que ele considera o "nobre e pequeno povo do mar", na "severa e branda" ilha de Guernsey, repleta de homens simples, pescadores, marinheiros, camponeses em constante luta pela sobrevivência e contra os desígnios da natureza. Sobre os homens dessa ilha o próprio autor assim os descreve: "duas espécies de lavradores, uns da terra, outros do mar" (VICTOR HUGO, 1866:2002, p. 50).

Em "Os trabalhadores do mar", o autor descreve os tipos comuns da ilha em uma narrativa que confronta, a todo o momento, o homem e a natureza. Dos diferentes tipos humanos, Victor Hugo revela seus medos, suas crenças, sua religiosidade, suas ambições, suas lutas. O trabalho contínuo dos camponeses, pastores, pescadores, quebradores de pedra, comerciantes, marinheiros, entre outros, conforme o próprio, assim descreve:

\footnotetext{
O Saint-Sampson de hoje é quase uma cidade; o Saint-Sampson de há quarenta anos era quase uma aldeia. [...] Digamos, além disso, que Saint Sampson, à exceção de algumas ricas famílias, é uma população de pedreiros e carpinteiros. O porto é um lugar de consertar navios. Durante o dia extraem-se pedras ou trabalham-se pranchas: aqui a picareta, além do martelo. Perpétuo meneio de pau e granito. À tarde tudo cai de cansaço e dorme como chumbo. Os duros trabalhadores fazem os duros sonos (VICTOR HUGO, 1866:2002, p. 313)
}

No fragmento acima, assim como em todo livro, além da descrição da natureza e dos tipos humanos, Victor Hugo mantém seu olhar atento às transformações da vida, da paisagem e do lugar, que se alteram lentamente, sob sua narrativa peculiar.

Um bom exemplo pode ser percebido durante a descrição da chegada do primeiro barco a vapor à localidade. A novidade que parece provocar inquietações e incômodos, também oferece as melhores perspectivas sob o ponto de vista econômico. 


\begin{abstract}
Mas pouco a pouco foram vendo que tais bois chegavam menos estafados, e vendiam-se melhor, por ser a carne mais tenra; que também para os homens eram menores os riscos do mar; que a passagem menos dispendiosa, era segura e mais curta; que eram fixas as horas da saída e da chegada; que o peixe viajando mais depressa, chegava mais fresco, e que se podiam levar aos mercados franceses as sobras das grandes pescas, tão frequentes em Guernsey; que a manteiga das admiráveis vacas de Guernsey fazia mais rapidamente o trajeto no Devil-Boat que nas chalupas à vela, e não perdia na qualidade, de maneira que afluíam as encomendas de Dinam, de Saint-Brieuc e de Rennes; finalmente que, graças ao que se chamava Galeota de Lethierry, havia segurança na viagem, regularidade na comunicação, multiplicação de mercados, extensão de comércio; em suma, que era preciso aproveitar o Devil-Boat que violava a Bíblia e enriquecia a ilha (VICTOR HUGO, 1866:2002, p. 63).
\end{abstract}

O barco a vapor de nome Durande de propriedade de Mess Lethierry, importante empreendedor da região, era, por si, um empreendimento comercial de boa monta, que o próprio Lethierry levara a vida toda para conquistar.

Sem contar com Clubin [o capitão da embarcação] tinha sete homens de tripulação; um timoneiro, um carvoeiro, um marinheiro carpinteiro, um cozinheiro, manobrista quando era preciso, dois trabalhadores da máquina e um grumete [marinheiro aprendiz]. Um dos penúltimos era também mecânico (VICTOR HUGO, 1866:2002, pp. 141-142).

Percebemos neste momento, ao longo das extensas narrativas, que uma das preocupações de Victor Hugo é também desvelar as relações de poder existente entre os moradores e trabalhadores da ilha. Percebe-se uma transformação local, que é antes de tudo econômica, forjando as relações, outrora puramente pré-capitalistas. Ao poder de Mess Lethierry irá opor-se um contra poder do Senhor Clubin, o capitão do navio, assim como as relações do próprio Clubin com seus liderados.

Mas não é só do trabalho no transporte marítimo que se faz a transformação da ilha. Victor Hugo mantém-se atento às diferentes mudanças em curso em Guernsey, sempre atrelada ao trabalho dos homens em sua luta contra a natureza: "O cais, a casa, o jardim, as marinhas, orladas de sebes, a maior parte das casas vizinhas, nada existe hoje. A exploração do granito de Guernsey fez vender os terrenos todos. Aquele lugar está hoje ocupado por estâncias de quebradores de pedra" (VICTOR HUGO, 1866:2002, p. 75). 
Na percepção aguçada de Victor Hugo para as transformações em curso, até mesmo a atividade turística, embora incipiente, já se faz percebida na pequena ilha. Em um das viagens da Durande havia a bordo seis passageiros: "um guernesiano, dois maloenses vendedores de animais, um turista, como já se dizia nesse tempo, um parisiense meio burguês, provavelmente turista do comércio, e um americano distribuidor de Bíblias" (VICTOR HUGO, 1866:2002, p. 141).

Embora as transformações transpareçam de forma clara na narrativa, na Guernsey de Vitor Hugo, nada nos remete à força do grande capital ao emprego dos grandes lucros, aos grandes negócios com o continente, enfim. Tudo ali nos sugere o mar, a terra, o povo e seu trabalho simples, duro, fatigante. Por certo, a transformação econômica também já se percebe na ilha, todavia por pequenos negócios, pequenos empresários, pequenas transformações locais. As estâncias de quebradores de pedra, um barco a vapor, um novo porto, um pequeno comércio com outras ilhas, com o continente, com a Inglaterra. Marcas de um lugar em transição, embora lenta, que nos remete a um período de transição entre a economia précapitalista e a chegada dos empreendimentos capitalistas, ainda que modestos.

Em resumo, na Guernsey de Victor Hugo percebemos que as condições de trabalho são impostas pelas condições do meio e ditadas pelas necessidades da localidade. Apesar disso, podemos perceber claramente os sinais de uma transformação da sociedade pelo trabalho, que começa a dar sinais da influência e da presença do capital.

Outro elemento em transição na ilha é a perda de poder da igreja sobre o povo, ainda fortemente influenciado pelas crendices e superstições. Tal influência começa a esvair-se com a sobreposição do progresso tecnológico e ganhos econômicos, conforme sugerido na passagem da inserção do barco a vapor na ilha, sendo este inicialmente apelidado de DevilBoat.

A transição parece eminente, porém não consolidada. As condições de vida e reprodução da sociedade ainda não estão totalmente presas aos fatores econômicos e financeiros. Aos poucos, a luta do "povo do mar", contra as severidades da natureza vai sendo alterada pela chegada de novos elementos da modernidade, que se instalam na pequena ilha e transformam as formas de vida e igualmente a sociedade guernesiana em seu pequeno território. 
Mas para demonstrar as profundas marcas da transformação da sociedade em seu espaço, precisaremos avançar no tempo e analisar as novas características da ilha de Victor Hugo, para a qual retornaremos ao final deste capítulo. 


\subsection{As origens do trabalho no turismo no Brasil}

Assim como em Sanditon ou em Guernsey, profundas transformações políticas, tecnológicas, econômicas, sociais, urbanas e culturais também começam a ser percebidas no Brasil, a partir do século XIX.

A vilegiatura marítima, ou seja, o ato de viajar para a beira-mar, de forma mais ou menos rotineira, com a finalidade de lazer, estudo, conhecimento ou repouso revigorante torna-se um hábito altamente disseminado entre as elites europeias, já nos século XVIII e XIX (CORBAIN, 1989, pp. 266-280).

Estas práticas, entretanto, não tardariam encontrar por aqui alguns seguidores, embora condicionados por diferentes situações muito particulares.

A esse respeito, entre nós, um dos mais antigos e sugestivos relatos da presença do hábito da vilegiatura marítima encontra-se nas memórias de Maria Paes de Barros, uma legítima herdeira da sociedade aristocrática paulistana, que nasceu em 1851, tendo se casado, em 1868, com Antônio Paes de Barros, senador da República pelo estado de São Paulo e de família tradicional ligada à cafeicultura.

Em suas memórias: "No tempo de Dantes", publicada em sua primeira edição em 1946, a autora passa a narrar suas experiências de vida em uma Paulicéia de pouco mais de 25.000 habitantes, uma vila monótona, com ruas vazias e poucos casebres, que conservava hábitos feudais e aparência medieval. Uma cidade pobre, que não oferecia diversões. "pelas ruas silenciosas só transitavam negros de calça e camisa de algodão, pés nus, cabeça descoberta - ou, de volta de alguma igreja...”(BARROS, 1946:1998, pp. 2-5).

Nesta vila pobre e monótona, em que vivia a autora, entretanto, já se esboçavam sinais de crescimento e progresso, sendo esta um corredor por onde passava grande parte da economia do café.

Naquela época, a maioria das famílias abastadas de São Paulo possuía fazendas no interior, sendo, portanto, hábito quase geral passarem alguns meses em suas terras, fugindo do áspero e úmido inverno para acompanhar e gerenciar os negócios.

Além dessa longa viagem ao interior, a família do Comendador Barros empreendia outra viagem, por "puro recreio", a Santos.

Preparavam-se todos alegremente para a estação que oferecia, além do sabor da novidade, a deliciosa perspectiva dos banhos de mar! Era quase sempre em São Vicente que se alojavam, nalguma velha casa da única rua existente na vila de 
Martim Afonso. [...] Lá se ia toda a família a empreender a cavalo a longa viagem com grande número de escravos, mucamas e pajens, além dos tocadores dos dois banguês que transportavam as crianças (BARROS, 1946:1998, p.60).

Como se vê a rica família partia para sua temporada de férias à beira-mar com forte aparato de escravos, mucamas e pajens, numa interessante contradição de uma sociedade escravocrata que anseia pelos prazeres do mundo moderno, conforme se presencia na Europa.

No Brasil, porém, é pelas mãos dos escravos que a moderna atividade do turismo irá ensaiar seus primeiros passos, conforme poderemos perceber no trecho a seguir:

\footnotetext{
À tardinha, entravam na silenciosa rua de São Vicente, ansiosos todos por um bom descanso. Já no dia seguinte eram os pretos mandados ao mato, onde cortavam galhos longos e bem enfolhados, com os quais armavam duas barracas na praia. [...] Com que paciência se esperava o término de tão simples construção! Apenas acabadas, já começavam os banhos. [...] Com que alegria eram recebidas as ondas altas que, passando por cima da cabeça, iam rebentar na frente, espumando! Ninguém devia, no entanto, abusar desse prazer. O banho durava de dois a três quartos de hora. Depois, era vestir-se depressa, ir para casa e tomar uma leve refeição. [...] À tarde, faziam passeios mais curtos com a boa Joaquina, que os levava a beber água na biquinha. [...] Os dias passavam ligeiros e em breve já haviam decorrido os dois meses de recreio em Santos (BARROS, 1946:1998, pp.61-63).
}

Avançando no tempo e procurando outros fragmentos do trabalho no turismo no Brasil, encontramos interessante passagem na obra do dramaturgo Artur de Azevedo (1855 1908), em sua comédia de costumes: "A Capital Federal”, trazida ao público da cidade do Rio de Janeiro no ano de 1897.

Arthur de Azevedo, irmão de Aluísio de Azevedo, foi um dos importantes escritores brasileiros daquele período, que juntamente com o irmão e Machado de Assis, entre outros, participou ativamente da criação da Academia Brasileira de Letras, onde criou a cadeira de número 29 e do próprio Teatro Municipal do Rio de Janeiro, sendo, portanto, um dos grandes contribuintes da cultura nacional.

Segundo João Roberto Faria, A Capital Federal, de Artur Azevedo, encenada pela primeira vez em fevereiro de 1897, "é uma síntese do teatro cômico e musicado, que foi hegemônico no Brasil nos três últimos decênios do século XIX." Em seu trabalho, Azevedo lança mão de recursos da comédia de costumes, operetas e paródias, para apresentar os 
contrastes entre o urbanismo moderno da cidade do Rio de Janeiro, que convive com um país arcaico e interiorano, sempre com muita graça e ironia e, ao mesmo tempo, com uma visão nada positiva do Rio de Janeiro, então capital federal (FARIA, 2016, p. 156).

Todavia, o que nos faz trazer este breve recorte do trabalho de Arthur de Azevedo a este estudo é, sem dúvida, o olhar astuto e perspicaz do artista, que conseguiu captar as nuances das transformações da sociedade carioca do período nos mínimos detalhes, a começar pelo local da peça.

Como já antecipamos, a peça de Arthuer de Azevedo tem início e se desenvolve em grande parte no saguão do Grande Hotel Nacional.

Neste palco surgem as situações cômicas da peça, com clientes, o gerente e os "criados" do hotel vivenciando situações do dia-a-dia de forma jocosa a desnudar os elementos de uma sociedade urbana que se transforma, tendo como exemplos os hábitos de Paris. No Grande Hotel Nacional, portanto, iremos encontrar, ainda sob um tom de comicidade, a síntese de uma sociedade em transformação.

Vamos agora a alguns fragmentos da peça:

Ação: no Rio de Janeiro, no fim do século passado.

Ato I

Quadro I

Suntuoso vestíbulo do Grande Hotel da Capital Federal. Escadaria ao fundo. Ao levantar o pano, a cena está cheia de hóspedes de ambos os sexos, com malas nas mãos, e criados e criadas que vão e vêm. O gerente do hotel anda daqui para ali na sua faina.

Cena I -

Um Gerente, um Inglês, uma Senhora, um Fazendeiro e um Hóspede.

Coro e Coplas

Os Hóspedes:

De esperar estamos fartos

Nós queremos descansar!

Sem demora aos nossos quartos

Faz favor de nos mandar!

Os Criados:

De esperar estamos fartos!

Precisamos descansar! 
Um hotel com tantos quartos

O topete faz suar!

Um Hóspede - Um banho quero!

Um Inglês - Aoh! Mim quer come!

Uma Senhora - Um quarto espero!

Um Fazendeiro - Eu estou com fome!

$O$ Gerente:

Um poucochinho de paciência!

Servidos todos vão ser, enfim!

Eu quando falo, fala a gerência!

Fiem-se em mim!

Coro - Pois paciência, Uma vez que assim quer a gerência!

O Gerente:

Este hotel está na berra!

Coisa é muito natural!

Jamais houve nesta terra

Um hotel assim mais tal!

Toda a gente, meus senhores,

Toda a gente, ao vê-lo, diz:

Que os não há superiores, na cidade de Paris!

Que belo hotel excepcional

O Grande Hotel da Capital Federal!

Coro - Que belo hotel excepcional, etc...

\section{Cena II -}

O Gerente, depois, Figueiredo:

O Gerente (Só):

Não há mãos a medir! Pudera! Se nunca houve no Rio de Janeiro um Hotel assim! Serviço elétrico de primeira ordem! Cozinha esplêndida, música de câmara durante as refeições da mesa-redonda! Um relógio pneumático em cada aposento! Banhos frios e quentes, duchas, sala de natação, ginástica e massagem! Grande salão com um plafond pintado pelos nossomeiros artistas! Enfim, uma verdadeira novidade! Antes de nos estabelecermos aqui, era uma vergonha! Havia hotéis em S. Paulo superiores aos melhores do Rio de Janeiro! Mas em boa hora foi organizada a Companhia do Grande Hotel da Capital Federal, que dotou essa cidade com um 
melhoramento tão reclamado! E o caso é que a empresa está dando ótimos dividendos e as ações andam por empenhos!

Pelas poucas passagens extraídas da obra de Azevedo podemos ver a ânsia expressa por possuir um hotel de grande monta na cidade, semelhante aos que se viam em Paris, já que algo parecido já se via em São Paulo, cidade esta que, poucos anos antes não passava de uma Pauliceia monótona.

As cenas da peça, aqui brevemente descritas, podem ser melhor compreendidas quando entendemos o contexto do Rio de Janeiro enquanto capital e maior cidade do país e importante zona portuária, porta de entrada natural de viajantes de todo mundo, com destino ao Brasil.

Uma cidade deste porte, aspirante a ser uma "Paris nos trópicos" possuia uma infraestrutura muito precária, embora os hábitos da população já almejassem elementos da modernidade existente na Europa.

Diante deste contexto de importantes transformações socio-espaciais é elucidante, neste ponto a inclusão da obra de Isabella Perrotta "Desenhando um paraíso tropical: a construção do Rio de Janeiro como destino turístico".

Trata-se de uma tese de doutorado, que investigou os primeiros guias turísticos elaborados pelas editoras da cidade do Rio de Janeiro, nas últimas décadas do século 19 e as primeiras décadas do século 20, com um recorte temporal que envolveu a análise de materiais produzidos no período entre 1873 a 1932.

Neste período, a autora pesquisou vasta quantidade de materiais e debruçou-se mais detidamente em 15 guias, que embora se apresentassem em formatos variados, quando analisados em conjunto permitem uma visão ampla, que possibilita analisar a transformação da cidade enquanto destino turístico.

No final do século 19, quando os primeiros dos nossos guias estão sendo lançados, o conceito de turismo ainda não estava consolidado e as viagens ao Brasil eram majoritariamente motivadas por interesses comerciais. [...] "Só em uma publicação de 1922 (o Guia artístico), encontramos a indicação de uma agência de turismo localizada na Avenida Rio Branco" (PERROTTA, 2011, p. 115).

Naquele tempo a cidade não era dotada de infraestrutura que pudesse tornar o turismo possível, sendo que as primeiras iniciativas turísticas foram protagonizadas por viajantes com propósitos comerciais, impulsionando negócios que tiveram origem em pequenas estruturas familiares e serviço de escravos (PERROTTA, 2011, p. 158). 
Perrotta aponta que, mesmo que no final do século 19, o Rio de Janeiro ainda não se configurasse como um destino turístico estruturado é provável que alguns estrangeiros já se aventurassem a desembarcar em seu porto meramente a passeio. Assim como a elite brasileira já viajava para a Europa com o mesmo fim. Ainda em 1887, a publicação "Impressões de viagem Brazil-Europa”, mesmo sem usar a palavra 'turismo', trata a viagem como fruição.

\footnotetext{
O viajar hoje é indispensável ao espírito investigador, e por toda a parte o homem que se move sente que vive, e as impressões da viagem dão-lhe uma segunda educação. Os que vêm visitar o novo mundo terão de admirar os grandes rios, serras e montes, colinas e várzeas, vastas florestas, de grandeza e esplendor como outra natureza não há superior. Os que vão percorrer as terras da Europa aprenderão novos costumes e por toda parte admirarão também o esplendor da natureza e não menos o trabalho do homem. Marcando o progresso do século em que vivemos. Tudo é grande e belo aos olhos de quem viaja; por toda parte novas cenas se descortinam a seus olhos, e para a alma sempre novas impressões, como que a criatura que viaja sente-se livre, sem que nada o incomode. Tudo é alegria (Guia de viagem Giolma, 1887, apud PERROTTA, 2011, p. 116).
}

Mas a autora somente encontra a palavra turista impressa em publicação de 1904, editado em língua francesa, por Olavo Bilac: "Não temos a intenção de fazer uma descrição completa da cidade, nem de percorrer com os turistas todas as ruas centrais. Nós faremos apenas um passeio à "voo de pássaro"” (BILAC; PASSOS; JÚNIOR, 1904:183 apud PERROTTA, 2011, p.116).

Os primeiros guias, como se pode notar, destinavam-se prioritariamente aos estrangeiros em atividade profissional e não de lazer. Destinavam-se a profissionais liberais, colonos para a agricultura e operários para as indústrias. Isso era percebido pelo tipo de informação apresentada, como os direitos dos estrangeiros no país, as leis específicas, a relação de cônsules em cada uma das cidades relacionadas, ou aos direitos dos cônjuges e filhos dos viajantes pelo Brasil.

De modo contrário, o guia produzido pelo Hotel Glória não deixa dúvidas de que se destina ao turista. Em 1932, o interesse definitivamente não é mais promover a imigração, mas sim promover o turismo. O hotel Glória deixa claro que a cidade acolhe bem o visitante, e aponta que mais de $20 \%$ da população é de estrangeiros, que se dedicam ao comércio, à indústria e às demais profissões. 
De uma maneira geral, a maioria dos guias analisados por Perrota, mesmo sendo voltados para o viajante de negócios procuram falar de turismo. Enquanto que, por outro lado, mesmo que voltados para o turista, procuram atender às demandas de negócios (PERROTTA, 2011, p. 126).

Pela passagem acima percebemos que a imbricação entre negócios e turismo não é tão recente, portanto, encontrando-se no início do século $\mathrm{XX}$, no caso brasileiro, raízes do que somente mais tarde viria a ser chamado de "turismo de negócios".

Outra característica presente no material analisado por Perrotta refere-se ao fato de que à medida que a cidade se sofisticava, e com ela sua natureza turística ia sendo construída, os hotéis melhoravam, oferecendo estruturas mais sofisticadas e, afastando-se do Centro aproximaram-se do mar e das áreas mais bucólicas da cidade (PERROTTA, 2011, p. 150).

Um bom exemplo disso é o Hand-Book of Rio de Janeiro, de 1887, que não acrescenta informações sobre o setor turístico no seu conteúdo editorial, mas seus anúncios são relevantes. Um deles, sob o título: "Tijuca, oferece transporte de bonde, da base da montanha para o alto, onde estão os hotéis Murray, White e Jourdain”. No mesmo anúncio são oferecidos passeios pitorescos e piqueniques. O Hotel Freitas, no largo da Lapa, diz-se localizado no ponto de partida para as excursões para o Jardim Botânico e Corcovado, a dois minutos de caminhada para o Passeio Público e próximo aos bondes para o "Plano Inclinado" [provavelmente para Santa Teresa]. Diz-se, ainda, que o hotel fornece informações sobre os pontos de interesse da cidade (PERROTTA, 2011, p.151).

Perrota ainda acrescenta que nos anúncios do Hotel Balneário e do Chalet Olinda, localizados em Botafogo, apesar de o texto não falar em banho de mar, este parece ser o apelo do nome do estabelecimento. Pelo guia Belchior \& Poyares (1987:70, 102 e 144), observa-se que o mesmo foi fundado em 1881, e localizava-se ao final da rua, próximo à casa de Saúde Dr. Eiras, gozando de boa reputação quanto às suas instalações. Mesmo relativamente afastado da praia, era o banho de mar que este hotel já propagava em anúncio quatro anos antes (1883) no Guia das cidades do Rio de Janeiro e Niterói:

\footnotetext{
Por ser a parte principal deste importante hotel o serviço dos banhos, que se acha organizado com luxo e ciência, o sistema de sua administração é igual ao de todos os hotéis balneários marítimos e centrais dos Estados Unidos, da Inglaterra, França, Alemanha, Suíça, etc., que reúnem sempre uma sociedade escolhida em consequência dos elementos confortáveis da vida, que se encontram nesses - HotéisPalácios (BELCHIOR; POYARES, 1987:101 apud PERROTTA, p. 151).
} 
Segundo a autora, ainda sobre a cidade do Rio de Janeiro,

[...] uma nova cidade, mais bonita, mais salubre e com um porto apto a fundear grandes embarcações foi constantemente descrita a partir do guia de 1904. Até que em 1932, contando com 1,8 milhão de habitantes e recebendo quatro mil vapores por ano, o Rio é descrito, numa das últimas publicações analisadas, como sendo a segunda cidade da América do Sul em população. Também como "um dos melhores e mais vastos" portos do mundo, além de principal centro comercial e industrial do país. Agora sim, este Rio moderno, que dava título ao guia, podia propagar "o título universalmente aceito, da mais formosa cidade do mundo em belezas naturais" e se considerar "uma importante estação de turismo internacional" (PERROTTA, 2011, p. 153).

Embora a atividade turística não tenha sido o mote principal dos primeiros guias para viajantes na cidade do Rio de Janeiro, as informações de cunho turístico vão ganhando espaço e relevância, conforme demonstrado por Perrota (2011). Influenciado pelo crescimento do país, pelo papel de capital da República, pela posição geográfica junto ao mar, pelas transformações sociais e culturais difundidas pela modernidade, o turismo no Rio de Janeiro não para de crescer.

Juntamente com as novas práticas, crescem os serviços a elas atrelados, como hospedagem (cada vez maior e melhor aparelhada), passeios, excursões, piqueniques, bares, restaurantes, bilhares, banhos de mar, transporte, teatros e casas de espetáculos, bibliotecas, inclusive agências de turismo e informações turísticas, promovendo em meio a tudo isso, o florescer de uma força de trabalho voltada diretamente aos serviços destinados aos turistas, em número cada vez maior.

Para finalizar esta rápida incursão sobre os primórdios do turismo no Rio de Janeiro, Perrotta reforça que,

[...] a inclusão da atividade turística no Rio se dá à medida que acontece a europeização de sua sociedade: a imitação ou adaptação, dos hábitos aristocráticos e burgueses estrangeiros; a fruição da natureza, passeios e piqueniques; o hábito de comer fora; a demanda por produtos e serviços de luxo como cristais, pinturas, joias, etc, que terão vitrine na Rua do Ouvidor. Aos poucos, as modestas casas brasileiras e a vida simples dos brasileiros se transformavam. [...] A cidade colonial passa a conviver com hábitos que desconhecia e que modernizavam sua vida cotidiana - e a modernidade é o berço do turismo (PERROTTA, 2011, p. 159). 
Assim, como aponta Perrota (2011), um conjunto de ações e práticas modernas ganha forma própria e conforma características turísticas da cidade do Rio de Janeiro. A reforma urbanística (com largas avenidas, praças, jardins e monumentos), o incremento dos meios de transportes e serviços de infraestrutura, a vida social e cultural dos cariocas, com seus divertimentos e lazeres, como os teatros, as exposições, a música popular e os esportes, tiveram importante papel na conversão da cidade em um dos mais importantes destinos de fluxos turísticos no país. Porém, neste e noutros estudos nota-se certo esquecimento quanto ao trabalho ou aos trabalhadores, enquanto força motriz deste nascente empreendimento coletivo.

Quase um século depois de Sanditon de Jane Austin, podemos perceber no Rio de Janeiro de Arthur de Azevedo e de Isabella Perrotta, a força dos arranjos espaciais como mecanismo para promover o uso turístico da cidade. Resta-nos lembrar de que os primeiros guias destinados aos viajantes eram descritos com o objetivo de facilitar as atividades de negócios, e que estes somente passam a contemplar aspectos de guias voltados ao turismo, com a chegada das primeiras décadas do século 20, quando a cidade já havia passado por várias obras de infraestrutura urbana e saneamento. Uma cidade moderna e à beira-mar passaria, então, a receber investimentos públicos e privados: de monumentos à hoteis, de largas avenidas às agencias de turismo. Estava assim "desenhado um paraíso tropical: a construção do Rio de Janeiro como destino turístico".

Com a chegada dos anos de 1930, o uso turístico do território da cidade do Rio de Janeiro, com seus promenades e arrabaldes já é uma realidade mais ou menos intensa, consolidando-se pouco a pouco, ao sabor e ao ritmo de proprietários como o Sr. Parker e Lady Denham (da fictícia Sanditon), quer seja por meio de investimentos privados ou públicos. O uso turístico do território obedecerá a ordem de um complexo conjunto de fatores e elementos e ganhará contornos próprios, em razão das especificidades de cada localidade.

Retornaremos agora à Guernsey, porém nos dias atuais, para identificar as novas características da antiga ilha de Victor Hugo e identificar as características de um novo mercado de trabalho. 


\subsection{A ilha de Guernsey hoje e os 'novos' trabalhadores do mar}

É possível supor que, acaso voltasse hoje à ilha de Guernsey, talvez o escritor Victor Hugo se impressionasse com as transformações do lugar. A começar pela sua ilustre residência, que se tornou um dos pontos turísticos de maior destaque da região, especialmente a partir de meados do século 20, com o avanço dos meios de transporte. Com isso, nos dias atuais, a ilha de Guernsey surge como uma "alternativa interessante" à já "consumida" costa sul da Inglaterra.

Já não restam mais traços da antiga Guernsey. Já não restam mais relações de trabalho mediadas pela natureza, como no romance de Victor Hugo. Estas passaram a ser mediadas unicamente pelo capital, como já era de se imaginar.

Neste novo cenário, as relações, o uso da terra e especialmente o trabalho serão introduzidos e ajustados de forma periférica a um complexo feixe de novas práticas, de um novo uso do tempo e um novo arranjo do espaço, imposto pelas novas formas de sociabilização, conforme sinalizara Alain Corbain.

A ilha tornou-se um destino turístico dos mais procurados pelos ingleses e europeus do continente, para as concorridas viagens de férias, feriados ou finais de semana.

Segundo dados do Guernsey Tourism Strategic Plan 2015 - 2025, a indústria do turismo local floresceu desde as décadas de 1960 e 1970, sendo hoje em dia uma das principais fontes de renda, com uma gama de atrativos turísticos: belezas naturais, com praias limpas e pouco frequentadas e ar puro; potencial para a prática de esportes náuticos, com elegantes marinas; forte apelo cultural e artístico, que conta com museus e galerias de arte; uma história de conquistas e invasões, que vão desde o Império Romano, até a ocupação nazista durante a $2^{\mathrm{a}}$ Guerra Mundial; além de diversas opções de lazer e compras no comércio local, concursos e festivais gastronômicos.

Atualmente, a atividade turística na ilha vem retomando seu crescimento, após a sensível queda com a crise econômica de 2008. Segundo os dados apontados pelo relatório supracitado, desde 2014 o Departamento de Comércio e Emprego tem tentado identificar o efeito da contribuição do turismo, em toda cadeia de valor e no varejo local. Por meio desta tentativa, o órgão responsável pelo turismo identificou que a contribuição do setor, por meio de gastos diretos e indiretos, chega à ordem de $£ 108,8$ milhões, contribuindo com $4,9 \%$ do PIB da ilha. Estima-se também que o aumento de $1 \%$ no número anual de visitantes à ilha equivale à contribuição de aproximadamente $£ 1.080 .000$ à economia com um todo. 
De acordo com outro relatório, o RESEARCH REPORT 2014 of Travel Survey for the States of Guernsey Commerce \& Employment Department, o número de visitantes naquele ano foi de 309.950 visitantes, sendo 188.850 , por via aérea e 121.100 , por via marítima, ou seja, acessaram diretamente os terminais portuários ou os aeroportos de Guernsey. A este número acrescentam-se os visitantes que chegaram por meio de cruzeiros marítimos (107.040), e àqueles que aportaram a ilha com suas embarcações particulares - iates (16.510 pessoas). Com isso, podemos concluir que, em 2014, Guernsey recebeu cerca de 433.500 visitantes, que permaneceram em média 4,3 noites na ilha, sendo, portanto, considerada uma boa opção regional para viagens curtas e feriados prolongados, o que pode inclusive ser percebido pela origem dos visitantes.

Quanto à origem dos visitantes, no mesmo ano, temos: $1^{\circ}$ ) Reino Unido - 69,8\%; $2^{\circ}$ ) Ilha de Jersey $-11,4 ; 3^{\circ}$ ) França $-6,3 \% ; 4^{\circ}$ ) Alemanha $-4,7 \%$ e; outros $-7,9 \%$.

Um fator de incremento turístico, que tem chamado muita atenção, refere-se ao número de cruzeiros marítimos em visita à ilha, com significativo aumento nos últimos cinco anos. Como já foi apontado, em 2014, 107 mil passageiros desembarcaram no porto de Guernsey, que é considerado um dos melhores portos europeus para cruzeiros marítimos. Em 2015 estimou-se que 115 rotas de cruzeiros visitariam a ilha, em comparação com 2014, onde 90 rotas aportaram naquele destino. Entre as companhias que operam em Guernsey estão: Celebrity Cruises, Saga Cruises, P\&O Cruises e Royal Caribbean Cruises.

A maior parte da rede hoteleira é composta por hotéis de três estrelas ou mais, com uma média de 70 leitos por hotel, sendo que os três principais grupos hoteleiros que operam na ilha são: o Best Western, o Hand Picked Hotel e o Red Carnation group, além de bandeiras que operam com o conceito de "budget hotéis" como: Premier Inn, Holiday Inn Express, Ibis and Jury's Inn, que ao todo oferecem aos visitantes 3.000 leitos. A estes se somam outros 2.000 leitos, oferecidos por pousadas e chalés, conforme aponta o documento acima citado.

Em Guernsey, como em todo mundo, o setor de operadores de turismo local, tem passado por uma forte pressão competitiva, com a tendência às reservas diretas através de sites de hotéis e empresas de transportes, ou até mesmo por meio dos chamados sites de busca, que agenciam a reserva de hotéis e passagens. As operadoras de turismo estão sendo espremidas por ambos os lados, com as novas opções diretas ao consumidor, e com isso os viajantes estão adquirindo taxas mais competitivas. Apesar disso, os operadores de turismo ainda são responsáveis pela fatia de 30 a $40 \%$ da chegada dos visitantes à ilha, além de serem importantes canais de marketing para promoção de Guernsey como um destino turístico, conforme aponta o relatório do plano estratégico do turismo local. 
Embora tenhamos tido acesso a muitas informações sobre o turismo da ilha, o número total de pessoal empregado no turismo local não pode ser precisado em nossa pesquisa. Somando-se apenas os três setores que contribuem mais diretamente com o turismo, que são: hotelaria (1.998); transporte (925); e artes, entretenimento e recreação (338); podemos estimar um total de 3.261 trabalhadores, perfazendo pouco mais de $10 \%$ do pessoal empregado na ilha, que contava com um total de 31.364 trabalhadores em 2014. Além deste número, outro contingente de trabalhadores indiretos contribui com a força de trabalho empregada no turismo da local, quer seja nos setores de comércio varejista e outros serviços, porém não conseguimos obter estes dados. Levando em conta uma população total de 62.711 habitantes, segundo o relatório Guernsey Facts and Figures 2015, podemos ainda estimar, embora com certa distorção, que aproximadamente 5\% dos guernesianos trabalhem no referido setor.

Tudo isso nos permite até mesmo elocubrar que, acaso Victor Hugo viesse a reescrever seu romance sobre a ilha, nos dias atuais, o mesmo não poderia deixar de incluir a história e a vida d'Os 'novos' trabalhadores do mar. A este grupo seriam incluídos: recepcionistas, atendentes, camareiras, garçons, operadores e guias de turismo, entre outros. Sem sombra de dúvida a força de trabalho guernesiana alterou-se profundamente nos dias atuais, assim como em muitas localidades, no Brasil e no mundo afora, onde a inserção do turismo se deu de forma marcante.

No próximo capítulo pretendemos então examinar com mais detalhes as características do trabalho, com destaque exclusivo ao Brasil, onde o trabalho no turismo precisa ser melhor estudado. 


\section{Capítulo 3 A força de trabalho no turismo}

Tão importante quanto saber a contribuição de um setor na geração de empregos é conhecer as características deste emprego. [...] Contribui para diagnosticar seus limites e desafios.

Coelho e Ramos, (IPEA, 2015).

\subsection{O trabalho no turismo}

Durante a realização desta pesquisa, o livro "Sanditon", de Jane Austen completou seus 200 anos de existência.

Escrito e deixado inacabado, em 1817, conforme anteriormente assinalado, a ficcional Sanditon parece ser um dos mais antigos e lúcidos registros das relações de poder e das relações de trabalho, em um território sob profundo processo de transformação, em função de uma prática social mais tarde convertida em atividade econômica denominada turismo.

Essas transformações, os novos interesses e as novas práticas ali presentes, de uma forma ou de outra, também foram percebidas no Rio de Janeiro de Arthur de Azevedo e Isabella Perrotta, ou na ilha de Guernsey, desde os tempos de Victor Hugo até os dias atuais.

Os poucos exemplos que compõem o capítulo anterior desta dissertação procuram demonstrar, ainda que de forma introdutória, que os territórios que se transformam em razão do turismo passam a ser configurados por um conjunto de novos "objetos turísticos" e de "objetos de suporte" à atividade e que estes novos objetos encontram-se em uma relação dialética com as transformações políticas, econômicas e sociais, bem como com as relações de trabalho.

E é sobre as novas relações de trabalho no turismo que pretendemos centrar nosso foco a partir de agora.

Para introduzir melhor o assunto faremos uso de um pequeno trecho dos estudos teóricos da professora Rita Cruz, que suportarão as ideias exposta a seguir. De acordo com Cruz,

[...] a intensificação do uso turístico de dada porção do espaço geográfico leva à introdução, multiplicação e, em geral, concentração espacial de objetos cuja função é dada pelo desenvolvimento da atividade. Entre esses objetos, destacam-se os meios de hospedagem, os equipamentos de 
restauração (relacionados à alimentação como restaurantes, bares, lanchonetes, entre outros) e de prestação de serviços e a infraestrutura de lazer. Nesse processo de apropriação dos espaços pela prática social do turismo está a gênese dos territórios turísticos (CRUZ, 2003, pp.12-13).

Esta passagem em especial se torna importante, pois será a partir da gênese dos "territórios turísticos"6 que iremos encontrar a gênese do trabalho no turismo. Ou seja, um conjunto específico de atividades laborais, no sentido lato do termo, que serão criadas e irmanadas para dar suporte ao funcionamento dos objetos turísticos instalados no território. Sejam estes objetos hotéis, restaurantes, prestação de serviços, entre outros.

A busca pelo encontro com a gênese do trabalho no turismo se faz necessário, pois o tema em estudo permanece entre um dos assuntos menos estudados dentre os principais temas ligados ao turismo e, segundo diversos autores, um tema onde reside uma das maiores dificuldades de entendimento.

Segundo Cruz, "outra parte importante das dificuldades daqueles que se dedicam a pesquisar o fenômeno do turismo de um modo geral e a sua dimensão espacial, especificamente, são as ambiguidades a ele imanentes, a começar pela sua própria natureza, ao mesmo tempo prática social e atividade econômica [...]” (CRUZ, 2007, p. 4).

Com este duplo aspecto, vemos que muitos estudos sobre o turismo se enveredam para os ganhos econômicos da atividade, os novos empreendimentos, os fluxos de passageiros, o crescimento do setor, a venda de passagens aéreas e hospedagens, os novos arranjos espaciais, as mudanças na paisagem que facilitam o acesso de turistas, sempre enaltecendo os ganhos do setor enquanto atividade econômica. Numa outra vertente, muitos estudos acentuam os conflitos, as contradições, as transformações causadas pelo turismo, trazendo à tona os prejuízos causados pela atividade junto às comunidades locais e à paisagem que são consumidos por uma indústria de enorme poder no mundo atual.

6. O uso das aspas pretende demarcar nosso entendimento de que não existem, na forma pura, territórios turísticos e sim usos turísticos dos territórios. 
Embora vejamos o embate das duas frentes, aparentemente ambas têm falhado em abordar o tema do trabalho no turismo. E é exatamente sobre esta lacuna que este trabalho se propôs enveredar, embora as dificuldades para a abordagem do tema sejam relevantes.

Para compreender melhor o trabalho no turismo, apesar da ambiguidade do fenômeno pensamos a nos ater, mais detidamente, ao turismo enquanto uma atividade econômica entendendo o trabalho no turismo como uma prática conjugada às lógicas do capital e ao modo de produção capitalista. É sob essa ótica que irá recair nossa investigação. 


\subsection{O trabalho no turismo sob a perspectiva da OMT}

No momento atual, embora tenhamos salientado a ausência de estudos sobre o trabalho no turismo, nos damos conta de uma crescente atenção ao tema. A própria Organização Mundial do Turismo - OMT (World Tourism Organization - UNWTO), que é uma agência especializada das Nações Unidas, com a responsabilidade pela promoção do acesso ao turismo internacional, tem sinalizado, a partir de um conjunto de estudos recentes, para o crescimento da atividade e a ausência de estudos sobre o trabalho no setor.

Segundo dados da OMT, com uma visão bastante parcial, a atividade é hoje uma chave para o desenvolvimento, prosperidade e bem-estar. Com mais de 1 bilhão de chegadas de turistas internacionais, um grande número de destinos turísticos estão sendo abertos em todo mundo, e investimentos no setor têm, supostamente, se tornado direcionadores do progresso socioeconômico através da criação de empregos, receitas de exportação e desenvolvimento de infraestruturas.

Ainda segundo a entidade supracitada, o turismo tem experimentado nas últimas seis décadas, uma contínua expansão e diversificação, para se tornar um dos setores de maior e mais rápido crescimento no mundo. Muitos novos destinos têm surgido e são adicionados aos tradicionais destinos como a Europa e América do Norte. Um crescimento ininterrupto ao longo do tempo, apesar de alguns choques, demonstraram a força do setor. A receita proveniente de viagens internacionais cresceu de US\$ 25 milhões em 1950 para US\$ 278 milhões em 1980, US\$ 674 milhões em 2000, e US\$ 1.186 milhões em 2015. Da mesma forma, as receitas internacionais do turismo mundial cresceram de US\$ 2 bilhões em 1950, para US\$ 104 bilhões em 1980, US\$ 495 bilhões em 2000, e US\$ 1.260 bilhões em 2015. O turismo é a maior categoria do comércio internacional de serviços e, em adição às receitas recebidas nos lugares mais visitados por turistas, o turismo internacional também gerou US\$ 211 bilhões em exportações através de serviços de transporte internacional de passageiros, trazendo um valor total de exportações acima de US\$1,5 trilhão, ou uma média de US\$ 4 bilhões por dia. O turismo internacional representa $7 \%$ das exportações mundiais em mercadorias e serviços, acima dos $6 \%$ em 2014, em razão do crescimento do turismo ter sido maior do que o do comércio mundial nos últimos quatro anos. Como uma categoria da exportação mundial, o turismo ocupa a terceira posição no ranking, atrás apenas de combustíveis e químicos. Em muitos países em desenvolvimento o turismo ocupa a primeira posição no setor de exportação ${ }^{7}$ (UNWTO, 2016, pp. 2-3). 
Apesar da propalada expansão aparentemente certa e ininterrupta do setor, os estudos da própria Organização Mundial do Turismo - OMT apontam para algumas preocupações ano a ano. Entre elas está a questão referente ao trabalho no setor.

Segundo a OMT, em uma de suas publicações: "Measuring Employment in the Tourism Industries - Guide with Best Practice" (2014), os dados relacionados ao emprego no turismo ainda são fragmentados e não têm qualidade e comparabilidade internacional.

A escassez e a falta de qualidade de informações sobre o tema parecem ter motivos variados e, aparentemente, a maioria delas reside na própria característica do turismo enquanto atividade econômica.

Com relação ao mundo do trabalho no setor, segundo a OMT, "o turismo envolve uma ampla variedade de diferentes atividades, tipos de estabelecimentos, contratos e acordos de trabalho". Para a referida entidade o turismo ainda fornece às pessoas renda, trabalho e experiência e contribui para a inclusão social e desenvolvimento pessoal. Por sua vez, o padrão de trabalho no turismo é caracterizado por notável diferença entre regiões de um país e entre estações do ano. E, para tanto, as estatísticas sobre o turismo e dados relativos ao emprego no turismo são fundamentais para entender o mercado de trabalho no setor visando à geração de políticas adequadas de criação de emprego, identificação das necessidades da força de trabalho, além de contribuir com um plano de desenvolvimento dos recursos humanos através da educação e formação de pessoal (UNWTO/ILO, 2014, pp. 9-10).

7. Britton (1979) apontava que "In small island economies, tourism's contribution to Gross National Product is considerably greater." Alguns exemplos davam conta de que "... tourism's contribution to GDP in the Bahamas was 45 per cent (...), 15 per cent in Trinidad and Tobago..." (UNCTAD, 1973:19 apud Britton, 1979, p. 19). Atualmente o turismo corresponde a $19 \%$ do PIB em Bahamas e 7,2\% do PIB em Trinidad e Tobago (www.bahamas.gov.bs/wps/portal/public/gov/government/news - WTTO Projects Bahamas Tourism Growth - 18/04/2018; http://www.tdc.co.tt/tourism_report.htm - The Travel \& Tourism Competitiveness Report, 2013) 
O aumento do interesse pelo trabalho na indústria do turismo é ainda mais justificado pelo fato de que "a indústria do turismo tem amadurecido em um mercado consumidor enfrentando crescente concorrência global e nacional, turbulências de mercado e mudanças na demanda do consumidor". As mudanças em processo chamam atenção para compreender a qualidade dos produtos e serviços, e a qualidade do pessoal empregado - um dos principais ativos da indústria do turismo, segundo a referida entidade. No entanto, os fatos e as conclusões apresentadas no guia da OMT só confirmam que "o mundo do trabalho no setor do turismo, em geral, e o valor econômico do turismo em termos de emprego, como fonte de trabalho produtivo em particular, permanecem inadequadamente medido e insuficientemente estudado" (UNWTO/ILO, 2008, pp. 10-11).

Ainda para a OMT, o turismo apresenta desafios para sua representação devido a sua natureza espacial. Trata-se de "um fenômeno social, cultural e econômico relacionado ao movimento de pessoas fora de seus locais de residência, e que causa impacto à economia, ao ambiente natural e construído, à população local, aos locais visitados e aos próprios visitantes". O turismo tem sido, assim, compreendido como um motor do desenvolvimento econômico, impactando um amplo leque de indústrias. Quanto à demanda, refere-se à atividade dos visitantes e suas expectativas na aquisição de mercadorias e serviços. Ao mesmo tempo, o turismo também pode ser visto pelo lado da oferta e é entendido como um conjunto de atividades produtivas provedora de produtos e serviços aos turistas e, como tal, podendo ser uma importante fonte de criação de emprego. E por isso, os países estão interessados em seu desenvolvimento visando à ativação da economia e a geração de empregos (UNWTO/ILO, 2014, p. 15).

Diante deste cenário, onde reside forte interesse econômico e busca por aumento de competitividade, cabe-nos aqui revelar um pouco mais sobre a visão da OMT sobre o mercado de trabalho no turismo.

Para a entidade, o mercado de trabalho em questão tem, por sua vez, uma dinâmica própria: alta rotatividade, ampla variedade de níveis e esquemas de remuneração, sazonalidade, entre outros. Nos países em desenvolvimento há, em geral, alta competição por trabalhadores, frequentemente jovens e com baixo nível de escolaridade. Além disso, por ser um setor de trabalho intensivo, oferece oportunidades para pessoas entrantes no mercado de trabalho, ou com dificuldades para fazê-lo. O turismo também tem um papel importante em prover oportunidades de trabalho, principalmente para pessoas com baixa qualificação, minorias étnicas, grupos de migrantes, jovens desempregados ou pessoas há muito tempo fora do mercado de trabalho, mulheres com responsabilidades familiares em busca de um emprego 
part-time e oferecendo oportunidade de ganhos suplementares para o pessoal aposentado. Em especial, a entidade destaca o setor de acomodação, como um pilar fundamental do turismo, que emprega uma grande porção de jovens trabalhadores e, significante quantidade de trabalhadores part-time, trabalhadores sazonais ou casuais, que proporciona a este setor uma alta rotatividade, e consequentemente maiores custos com contratação e treinamento de pessoal (UNWTO/ILO, 2014, pp. 16-17).

$\mathrm{Na}$ busca por respostas às demandas, percebe-se um aumento de estudos sobre o trabalho e o emprego no setor de turismo, nos últimos anos, quer seja em âmbito internacional ou nacional. Dentre os muitos exemplos, um dos melhores esforços que expressam o recente aumento do interesse pelo entendimento do trabalho no turismo tem sido oferecido pela própria OMT, que estabeleceu uma parceria recente (2008-2009) com a Organização Internacional do Trabalho - OIT.

$\mathrm{Na}$ recente publicação da World Tourism Organization and International Labour Organization: Measuring Employment in the Tourism Industries - Guide with Best Practices, UNWTO, (2014), obtemos mais detalhes deste acordo de cooperação inter-agências, ratificado pelos respectivos corpos diretivos das duas entidades. Os objetivos finais deste acordo estão estabelecidos nas seguintes bases: a) melhoria da confiabilidade e comparabilidade dos dados sobre o emprego na indústria do turismo; b) configuração e teste de um conjunto de indicadores estatísticos de trabalho para medir o progresso em relação ao trabalho decente em turismo; c) elaboração de um guia completo conjunto com as melhores práticas de medição de emprego nas indústrias do turismo; d) promoção de normas internacionais em matéria de estatísticas do trabalho e turismo.

Em linha com os objetivos do referido acordo, foram produzidos os seguintes trabalhos:

- Joint ILO/UNWTO publication on Sources and Methods in Labour Statistics Employment in the Tourism industries (Special Edition) - 2008;

- New chapter on Employment in the tourism industries in the revised International Recommendations for Tourism Statistics 2008 (IRTS 2008, chapter 7) e;

- Comprehensive technical guide for chapter 7 of the Compilation Guide for Tourism Statistics - 2008. 
O aumento no número de estudos, que visam um maior entendimento sobre o trabalho e o emprego no turismo é mais facilmente entendido quando nos deparamos com o propósito de tais iniciativas por parte da OMT. Para esta entidade, o turismo é um setor movimentado composto essencialmente por pessoas, porém, os dados relativos ao trabalho e ao emprego no turismo ainda são fragmentados, possuem pouca qualidade e comparação internacional, sendo estas características percebíveis, não somente em nível internacional, mas também em nível nacional, onde diferentes métodos e fontes de dados frequentemente resultam em diferentes números e resultados.

Por tudo isso, a intenção da OMT é clara: melhorando a qualidade e a comparabilidade das estatísticas sobre o emprego no turismo, a organização entende que se pode melhorar significativamente o monitoramento do mercado de trabalho no setor e promover atividades produtivas, visando um uso mais efetivo do trabalho qualificado, para assegurar o desenvolvimento do turismo sustentável e contribuir para o crescimento econômico e o emprego.

Para tanto, segundo a OMT, uma força de trabalho qualificada garantiria uma maior competitividade e inovação e melhoraria as perspectivas de trabalho, além de facilitar o processo de ajustamento às rápidas mudanças do mercado. As questões do emprego e dos recursos humanos devem ser temas-chave para a investigação e estudos analíticos nas indústrias do turismo. De acordo com os estudos desenvolvidos pela entidade "o emprego nas indústrias do turismo refere-se a todos os trabalhos (ou pessoas envolvidas) em ambas as atividades características do turismo e em todos os estabelecimentos e indústrias de turismo.” A necessidade de uma gama de dados estatísticos no setor do turismo é visto como um passo importante na obtenção de uma melhor compreensão da estrutura do emprego da indústria do turismo e para a elaboração de políticas por parte dos governos em questões que afetam o setor. O foco no emprego é reforçado pelo fato de que o setor do turismo evoluiu para um mercado consumidor mais complexo, que requer uma maior atenção, não só com a qualidade em produtos e serviços, mas também com a qualidade dos recursos humanos "um dos principais ativos do setor" (UNWTO/ILO, 2014, pp. 20-21).

Como se pode concluir, a partir das ideias acima, há um claro interesse pelos estudos referentes ao trabalho e emprego no turismo em tempos recentes. Em razão do aumento e da maturidade do setor, frente às novas exigências e mudanças no mercado, vislumbra-se o desenvolvimento da força de trabalho como uma das alavancas de aumento dos ganhos e do lucro. 
Diante deste cenário, a OMT busca desempenhar um papel de organização dos estudos e dados estatísticos e da integração das informações do setor, quer seja pela normatização das nomenclaturas e termos técnicos adotados, quer seja pela definição de metodologias específicas, ou mesmo pela orientação e desenvolvimento de estudos. Para a OMT, a harmonização e o ajuste dos dados irá permitir a comparação e o estabelecimento de melhores práticas.

Para a OMT, no entanto, poucos países têm a capacidade e ferramentas analíticas para medir o emprego e a contribuição do turismo em suas respectivas economias e seus respectivos PIBs. Sendo que, Áustria, Brasil, Canadá, Irlanda, Nova Zelândia, Espanha, Suíça e Reino Unido são bons estudos de caso, com modelos que exemplificam boas práticas na mensuração do emprego, salários, horas de trabalho e outras variáveis (UNWTO/ILO, 2014, p. 38).

Por tudo o que foi exposto até aqui podemos perceber os motivos que levam a OMT a ampliar seus investimentos para conhecer melhor e qualificar a força de trabalho no turismo. O interesse econômico é grande e os esforços tendem a aumentar nesse sentido, já que é por meio do trabalho no turismo que o serviço ao turista poderá ser oferecido. Ou seja, é por meio do trabalho no turismo que o turismo se realiza e o lucro acontece.

Mas não é apenas a OMT que analisa a importância do trabalho no turismo, bem como suas características e particularidades. Outros autores, com outros olhares e, numa perspectiva mais crítica, também têm empreendido estudos sobre o tema, os quais analisaremos à frente.

Todavia, por ora vamos nos ater à compreensão do desenvolvimento do trabalho no turismo no Brasil. 


\subsection{O trabalho no turismo no Brasil}

Desde o início das atividades do turismo no Brasil, o trabalho no turismo foi alvo de pouca atenção.

Assim como em todo o mundo, o trabalho no turismo no país sempre esteve entre os temas pouco estudados, passando a receber uma maior atenção no período mais recente.

No início da década de 1990, com a estabilização econômica do país, estudos mais específicos passaram a ser realizados com vistas ao aumento do entendimento do trabalho como forma de melhorar a mão de obra no setor.

Com a virada do século e a expansão da atividade econômica, tanto no mundo, quanto no Brasil intensificaram-se os estudos a sistematização dos dados, propiciando uma melhora no entendimento do tema.

Neste capítulo pretendemos expor de forma mais ampla os estudos realizados e propor um retrato sobre o estudo do tema no país.

\subsubsection{A evolução recente dos estudos sobre o trabalho no turismo no Brasil}

A despeito das dificuldades de obtenção de dados e estudos específicos sobre o trabalho no turismo, Árias aponta que, são poucas as iniciativas de entendimento do trabalho e emprego no setor. De acordo com o autor, os poucos trabalhos sobre o tema no Brasil, desenvolvidos na primeira década do século XXI podem ser divididos em estudos de dois tipos: 1) análises abrangentes baseadas em fontes secundárias; ou 2) diagnósticos setoriais embasados em pesquisas de campo (IPEA, 2003, p.8).

No primeiro grupo destaca-se principalmente o livro: "O mercado de trabalho na atividade econômica do turismo no Brasil”, de 2001, de autoria de Jorge Saba Arbache, que “constitui-se um trabalho pioneiro, em área tão carente de produção de conhecimento" (IPEA, 2003, p.8).

Este livro propicia um melhor entendimento do mercado de trabalho no turismo no período que compreende as décadas de 1980 e 1990, sendo considerada uma das primeiras obras do gênero no país e adquirindo certa relevância dada à escassez de publicações a respeito do tema. 
Logo na introdução do livro o autor deixa claro que o tema principal, o trabalho no turismo, é de suma importância e destaca ainda que,

[...] uma das áreas que mais tem sido negligenciada na literatura acadêmica é a que analisa o mercado de trabalho na atividade econômica do turismo, o que é surpreendente, já que o principal insumo do setor é a mão-de-obra. [...] Na verdade, pouco se sabe, por exemplo, sobre o funcionamento e as características do mercado de trabalho nesse setor e se ele se difere do mercado de trabalho do restante da economia (ARBACHE, 2001, p. 15).

Em seu livro, o autor aponta que embora as décadas de 1980 e 1990 tenham sido marcadas pela estagnação econômica, elas tiveram características distintas. Por exemplo, o período que vai de 1980 a 1994 foi caracterizado pela elevada inflação e deterioração macroeconômica, enquanto que os anos seguintes experimentaram estabilização de preços e reorganização da economia. Para o autor, o comportamento da economia e as flutuações macroeconômicas observadas nas duas últimas décadas, devem ter, muito provavelmente, influenciado a forte variação nos números absolutos e relativos da ocupação no setor, pois, "como se sabe, o turismo, como bem de luxo, é bastante influenciado pelo desempenho econômico" (ARBACHE, 2001, pp. 19-24).

Na medida em que o turismo é um bem de luxo e que a elasticidade do consumo de
turismo em relação à renda é elevada, o que faz com que seu consumo seja
abandonado ou reduzido em períodos recessivos espera-se que variações no
panorama macroeconômico tenham significativos reflexos no nível da ocupação da
indústria, notadamente na contratação de novos empregados (IPEA, 2001, pp. 2627).

Quanto ao rendimento dos trabalhadores no setor e sua evolução no tempo, foram comparados os rendimentos dos ocupados no turismo, tanto com os demais setores da atividade econômica, quanto entre os diferentes grupos de atividade dentro do próprio setor do turismo. Pela análise, o autor revela que, "na década de 1980, os rendimentos do setor turismo estavam entre os mais baixos e superavam apenas os rendimentos dos serviços sociais, agricultura, construção civil e prestação de serviços" (ARBACHE, 2001, p. 30).

A pesquisa de Arbache também aponta que, 
[...] o tempo médio do emprego no turismo está entre os mais baixos - em torno de cinco anos -, o qual é muito inferior ao observado em praticamente todos os demais setores de atividade. O tempo de emprego médio na economia é próximo há sete anos. Logo há discrepância em desfavor da indústria do turismo, indicando que a rotatividade da mão-de-obra no setor turismo é relativamente elevada (ARBACHE, 2001, p. 46).

O autor ainda destaca que o segmento de hospedagem é o que apresenta os piores indicadores de período médio de emprego, enquanto o segmento de agências de viagem e turismo apresenta os melhores indicadores.

Quanto à distribuição geográfica, os dados da pesquisa reforçam as impressões já existentes, de que as regiões mais dinâmicas economicamente apresentam maior quantidade de trabalhadores no turismo, bem como remuneram melhor. Os números levantados mostram que, na Região Sudeste encontram-se 35\% dos trabalhadores ocupados, enquanto que, na Região Nordeste tem-se 28\%, na Região Sul, 17\%, Centro-Oeste, $13 \%$ e Norte, $7 \%$. Segundo o autor, ao longo do período pesquisado esses números pouco se alteraram, revelando um padrão de espacialização consolidado.

A importância da obra de Arbache revela-se pelo tratamento dado a um bom número de variáveis como: número de ocupação; rendimento; escolaridade; experiência; tempo no emprego; gênero; raça; natureza do contrato de trabalho; distribuição da ocupação; sindicalização e; distribuição geográfica.

A análise de cada uma dessas variáveis contribuiu para a ampliação do estudo e entendimento do tema, reforçando ou se contrapondo a outros estudos realizados. Acrescentase, ainda, o fato de o autor considerar que o setor parece ter grande capacidade de criar e destruir postos de trabalho, sendo muito sensível aos ciclos econômicos.

Como bem de luxo, a demanda por turismo tende a variar com o desempenho da economia e mudanças na renda per capita. A estabilização econômica, o aumento da renda e a melhoria de sua distribuição parecem ser requisitos para promover $\mathrm{o}$ crescimento do consumo de turismo e a geração de empregos no setor (ARBACHE, 2001, p. 90).

Já quanto a um segundo grupo destacado por Árias, encontramos um estudo promovido pela EMBRATUR, em 1995, denominado: “Condições e perspectivas do mercado de trabalho no setor turismo - Segmento Hotel". Este esforço de pesquisa foi desenvolvido 
pela Fundação Instituto de Pesquisas Econômicas - FIPE e coordenada por Wilson Abrahão Rabahy, sendo embasado por pesquisa de campo realizada em cinco capitais brasileiras, traçando um perfil da força de trabalho estabelecida na atividade hoteleira.

Este trabalho foi elaborado por solicitação do Grupo Interministerial de Capacitação Profissional, da Câmara Setorial do Turismo do Ministério da Indústria, do Comércio e do Turismo, sendo financiada pelo Programa das Nações Unidas para o Desenvolvimento PNUD, sob o gerenciamento do Ministério do Trabalho.

Logo no início da apresentação do estudo percebe-se a preocupação da equipe que conduziu a pesquisa, em relatar o aumento no número de chegadas de turistas internacionais no Brasil, a falta de políticas em favor do setor e, entre outros aspectos, "pela falta de uma política de formação, treinamento e qualificação da mão-de-obra, principal matéria-prima do setor" (RABAHY, 1995, p.9).

Em análise ao método adotado na pesquisa citada podemos verificar que, quanto à delimitação do problema, o presente trabalho selecionou cinco cidades (São Paulo, Rio de Janeiro, Manaus, Florianópolis e Salvador), que seriam representativas da diversidade das regiões do país, visando definir uma política interministerial de formação e aperfeiçoamento de recursos humanos para o turismo, que fosse adequada à realidade brasileira.

O estudo foi realizado por meio de formulários para a coleta de dados junto a hotéis, restaurantes turísticos, centros de convenções, espaços para eventos, agências de viagens e turismo e escolas de cursos destinados à formação de profissionais do turismo.

Quanto ao nível de escolaridade, a pesquisa identificou que, de uma maneira geral, predomina um baixo nível de escolaridade no pessoal pesquisado. Quase $70 \%$ possuía no máximo o $1^{\circ} \mathrm{Grau}$, sendo que a Governança apresentava $87,8 \%$ de pessoal com escolaridade igual ou inferior ao $1^{\circ}$ Grau, seguido de Cozinha e Restaurante, com respectivamente, 86,6\%, e $78,2 \%$

A época da realização deste estudo (1995) caracteriza-se como o período imediatamente após o estabelecimento do Plano Real, onde se esboça um quadro de estabilidade econômica e política, promovendo um clima de perspectivas otimistas no setor hoteleiro.

Tal otimismo leva os empresários a projetarem investimentos no aumento das unidades habitacionais, implantação de equipamentos de informática e a projeção de aumento de receitas (RABAHY, 1995, p. 151). 
Entre os motivadores externos, que levam os empresários do setor a expectativas tão otimistas são apontados: preços estáveis (redução da inflação), 25,2\%; um novo governo, 20,4\%; o fortalecimento do mercado interno, 17,1\%; a taxa de câmbio favorável, 3,9\%; o aumento do poder aquisitivo, 3,9\%; clima de otimismo, 2,6\%. Diante de tanto otimismo, mudanças na tecnologia e nos sistemas organizacionais se tornam necessários, sendo que tais mudanças podem ser sintetizadas por: mais informatização na administração; integração em sistemas informatizados de reservas; automatização dos serviços operacionais; check-in / check-out automáticos; redução da burocracia administrativa; atendimento personalizado; terceirização de serviços; estímulo à polivalência dos funcionários; entre outras. Por tudo isso, com relação às mudanças previstas na força de trabalho destaca-se, além do estímulo à atuação polivalente dos funcionários, uma alteração na composição da mão-de-obra feminina no quadro de pessoal nos setores da Administração, Recepção, Governança, Restaurante e Cozinha (RABAHY, 1995, pp. 155-156).

As perspectivas de ampliação da hotelaria e das mudanças organizacionais, por sua vez, implicam na redefinição e redimensionamento no quadro de pessoal e na consequente necessidade de formação profissional. Diante do quadro de mudanças, $60 \%$ dos entrevistados consideraram que a formação de pessoal para os próximos anos seria necessária, ou muito necessária (RABAHY, 1995, pp. 160-163).

Os dois trabalhos trazidos sob análise até este momento, representam uma época de transição econômica e retratam um período de retomada de investimentos e novas expectativas quanto à atividade do turismo no Brasil. Ao longo da primeira década do século XXI, no entanto, após a consolidação da economia na década anterior, o trabalho no turismo passou a receber uma maior atenção por meio de um aumento no número de pesquisas e superação de aspectos metodológicos importantes, conforme veremos no próximo tópico.

\subsubsection{A parceria MTur/IPEA e o Sistema de Informações sobre o Mercado de Trabalho no Turismo - SIMT}

Após um período de esquecimento e obscuridade, o trabalho no turismo passou a receber maior atenção e estudos sistematizados, como buscamos evidenciar. 
Em linha com as diretrizes e propósitos da OMT, o Brasil passou a desenvolver um material teórico e um conjunto de dados estatísticos sobre o trabalho e emprego no turismo. A principal iniciativa a esse respeito foi a parceria firmada, em 2003, entre o Ministério do Turismo - MTur, o Instituto de Pesquisa Econômica Aplicada - IPEA e a Companhia de Planejamento do Distrito Federal - Codeplan/DF, que juntos vêm desenvolvendo o Sistema de Informações sobre o Mercado de Trabalho no Setor Turismo - SIMT.

Este projeto tem como objetivo oferecer para o governo e à sociedade informações que subsidiem a formulação e avaliação das políticas públicas de turismo e orientem os dirigentes do setor, trabalhadores, pesquisadores e instituições de fomento e desenvolvimento.

O conjunto de informações levantadas permite avaliar o turismo enquanto atividade econômica em vários aspectos, mas principalmente enquanto a geração de empregos (formais e informais), bem como o perfil da força de trabalho e sua distribuição geográfica pelo país, nas diferentes atividades e subsetores que compõem o setor turismo. Estas atividades são chamadas de Atividades Características do Turismo - ACTs, um conjunto de atividades que concentram a maior parte dos gastos dos turistas.

Na metodologia utilizada pelo IPEA, que leva em conta as sugestões da OMT, foram definidas, para o Brasil, as seguintes ACTs: Alojamento; Alimentação; Transporte Aéreo; Transporte Terrestre; Transporte Aquaviário; Agências de Viagem; Aluguel de Transporte e; Cultura e Lazer.

Além da definição das ACTs, a principal limitação ao desenvolvimento dos trabalhos do IPEA fora a dificuldade de distinguir as proporções de atendimento aos residentes e aos turistas nos serviços prestados pelos estabelecimentos que operam nas ACTs.

Em razão da ausência desses dados, os estudos elaborados utilizavam-se de estimativas sobre as quantidades de pessoal empregado que trabalham atendendo turistas em cada uma das ACTs. Muitas estimativas pressupunham que toda a ocupação era derivada do atendimento a turistas. E esse tipo de distorção, todavia, ocorre de forma mais acentuada em atividades como alimentação e cultura e lazer, nas quais o consumo dos turistas constitui, em muitos casos, parcela reduzida se comparado ao consumo dos residentes.

O Sistema de Informações sobre o Mercado de Trabalho no Setor Turismo - SIMT visa suprir essa carência de informações por meio de um coeficiente desenvolvido pelo IPEA, 
que possibilitou distinguir o atendimento feito aos turistas e aos residentes, em cada uma das ACTs. Esse coeficiente foi estabelecido por meio de uma ampla pesquisa telefônica junto aos estabelecimentos cadastrados no registro administrativo do Ministério do Trabalho e Emprego.

Esses dados, porém, foram divulgados apenas até o nível das Unidades da Federação UFs, já que a dimensão da amostra não permite calcular os coeficientes no nível municipal.

Segundo dados divulgados pelo IPEA, a fonte utilizada para dimensionar e caracterizar a ocupação formal do turismo é a Relação Anual de Informações Sociais - RAIS, que é o registro administrativo do Ministério do Trabalho e Emprego (MTE) com elevada cobertura. Ela abrange praticamente o universo dos estabelecimentos com vínculos empregatícios regidos pela Consolidação das Leis do Trabalho (CLT) e traz também informações sobre os servidores públicos da administração direta e de fundações. A RAIS apresenta os dados referentes ao total dos ocupados nas ACTs, porém sem informações relativas ao consumo turístico nas ACTs.

Para corrigir a distorção do atendimento aos turistas e aos residentes, o IPEA realizou, mediante consulta por telefone em 2005 e 2010, pesquisas para identificar o consumo de residentes e turistas tendo por base uma amostra estratificada por atividade, estado e dimensão do estabelecimento, em todas as unidades da federação.

Essas pesquisas mostraram grandes diferenças nas porcentagens de atendimento turístico e não turístico entre as ACTs e também constataram diferenças entre as UFs, grupos por tamanho dos estabelecimentos e meses do ano. Esses resultados permitiram apurar a proporção de consumo de turistas e de residentes nos 12 meses precedentes à realização das pesquisas. Por meio de tratamento estatístico, estimaram-se os coeficientes de consumo turístico para as ACTs, por estado e por mês, de forma a identificar sua sazonalidade. $\mathrm{O}$ cruzamento desses coeficientes mensais de participação do consumo turístico nas ACTs com os estoques de emprego formal constantes da RAIS, por atividade e por estado, permitiu a elaboração das estimativas da dimensão do emprego formal no turismo, apresentadas entre 2006 a 2014. A RAIS, entretanto, só levanta dados relativos ao emprego formal, deixando de fora grande parte das ocupações do turismo, de natureza informal, correspondente a pessoas que trabalham na condição de proprietário, familiares não remunerados, trabalhadores por conta própria e aqueles que não têm carteira assinada ${ }^{8}$. 
Segundo Sakowski (2013), os resultados obtidos por meio das pesquisas realizadas pelo SIMT, em curso são fruto de uma metodologia desenvolvida pelo IPEA, especialmente para lidar com as dificuldades do tema, incluindo o levantamento da base de dados sobre emprego no país e o estabelecimento de um coeficiente de demanda no turismo.

Conforme aponta Sakowski,

[...] as estimativas da ocupação formal do setor turismo são feitas a partir do cruzamento dos dados sobre o número de ocupados declarados na Relação Anual de Informações Sociais (RAIS), do Ministério do Trabalho e Emprego (MTE), para um conjunto selecionado de atividades, com os coeficientes de demanda turística que expressam a porcentagem de atendimento a turistas no estabelecimento, para os doze meses do ano. Os coeficientes de demanda turística são calculados a partir de uma pesquisa realizada pelo IPEA, a cada cinco anos, em estabelecimentos que operam nas principais atividades características do turismo. A primeira pesquisa foi realizada em 2004 e 2005, quando cerca de 8 mil estabelecimentos em todas as Unidades da Federação (UFs) foram entrevistados, possibilitando a construção de coeficientes mensais para sete ACTs, em dezenove agrupamentos geográficos (quatorze estados com coeficientes individuais e os demais estados com coeficientes definidos para cinco grupos) (IPEA, 2013, p. 7).

Apesar dos esforços, muitos são os desafios inerentes à pesquisa sobre o trabalho no turismo, entre as quais o citado coeficiente de atendimento no turismo, que procura atenuar a distorção existente no setor, já que nem todo trabalhador atuando no setor turismo atende única e exclusivamente a turistas.

Outra dificuldade reside na classificação das atividades que são consideradas como componentes do turismo. Tal preocupação se faz relevante, pois o turismo é composto por muitas atividades, sendo que muitas delas são muito próprias e particulares à atividade, enquanto outras são importantes, tanto para o turismo quanto para a população local.

8. IPEA, Extrator de Dados - Sistema de Informações sobre o Mercado de Trabalho no Setor Turismo - SIMT, <http://www.ipea.gov.br/extrator/simt.html> consulta realizada em: 30/10/2016. 
Um clássico exemplo pode ser trazido pelas atividades de alojamento (hotelaria) e alimentação (restaurantes). Ambas são amplamente utilizadas por turistas, embora os restaurantes, além de serem utilizados por turistas são, muitas vezes, também frequentemente utilizados pela população residente. Enquanto isso, a rede hoteleira caracteriza-se pela utilização, sem dúvida mais frequente por turistas.

Além do estabelecimento da metodologia para definição do coeficiente de demanda turística e das ACTs, a parceria MTur-IPEA tem produzido outros materiais e estudos sobre o tema.

De acordo com o texto: "Perfil da mão de obra do turismo no Brasil nas atividades características do turismo e em ocupações" (2014), as autoras Coelho e Sakowski indicam que,

[...] o turismo tem sido apontado como alternativa importante em termos de criação de oportunidades de trabalho, tanto no plano nacional como local e, portanto, a formulação de políticas, estratégias e ações voltadas para o setor com esse fim demanda informações sobre a realidade de seu mercado de trabalho. Nesse sentido, a qualidade dos serviços prestados aos turistas é requisito para o aumento da oferta turística e da competitividade do país. Fatores como a sazonalidade inerente ao setor, baixa escolaridade dos empregados, alta rotatividade, entre outros, dificultam a qualificação da mão de obra e comprometem serviços oferecidos, tornando-se desafios para o setor. [Nesse sentido,] [...] é importante conhecer melhor o perfil do empregado que atenderá esse público (turistas), para que os responsáveis, tanto no setor público quanto privado, possam atuar de maneira objetiva no que se refere à capacitação da mão de obra do setor (IPEA, 2014, p. 7).

Adentrando um pouco mais na análise dos estudos realizados pelo IPEA iniciamos agora uma análise ao primeiro material produzido pelo IPEA, no âmbito da parceria estabelecida com o Ministério do Turismo, intitulado: "Uma leitura da evolução recente do mercado de trabalho do setor turismo no Brasil".

Este estudo traça um retrato da evolução do mercado de trabalho no turismo no Brasil, no período entre 1995 a 2001, utilizando como base os dados de duas fontes secundárias de cobertura nacional: a) Pesquisa Nacional por Amostra de Domicílios - PNAD, realizada pelo IBGE, e; b) a Relação Anual de Informações Sociais - RAIS, um levantamento estatístico anual elaborado pelo Ministério do Trabalho. 
Quanto ao estudo em análise, logo na apresentação do mesmo, os autores apontam que este material deve ser entendido como a primeira iniciativa do IPEA neste assunto e que, "diferentemente do que se vem apregoando sobre o setor, aponta para um desempenho modesto, em termos de geração de emprego formal e de renda" (IPEA, 2003, p.4).

Ainda na apresentação, os autores também apontam que o estudo "não tem a pretensão de trazer respostas definitivas, mas o propósito de contribuir para o aperfeiçoamento da compreensão de questões relacionadas ao mercado de trabalho no setor turismo, cuja complexidade é reconhecida por aqueles que têm se dedicado a interpretá-las" (IPEA, 2003, p.4).

Quanto a isso, os autores reforçam que, apesar do potencial da atividade turística apontar para um crescimento, ainda é incerto afirmar certos prognósticos, em razão de que ainda não se dispõe de dados contínuos confiáveis e completos acerca do que o turismo representa na economia da maior parte dos países, embora esforços estejam sendo feitos na ampliação dos sistemas de informação para o entendimento de diferentes variáveis sobre o turismo, entre elas estimativas sobre o emprego no setor (IPEA, 2003, pp.5-6).

O estudo também aponta que as dificuldades para a obtenção de dados confiáveis sobre emprego no setor turismo se faz presente não só no país, mas em nível mundial, conforme a passagem a seguir:

A respeito do tema emprego, a própria OMT explicita as dificuldades para conseguir avanços mais significativos, ao advertir que a sazonalidade, a grande variabilidade nas condições trabalhistas, a flexibilização e a escassa formalização dos vínculos trabalhistas em muitas unidades produtivas de pequeno porte são os principais obstáculos para obter dados significativos sobre o emprego no setor de turismo. [...] Isso explica porque as limitações estatísticas não permitem que essas recomendações sejam muito ambiciosas por enquanto, apesar de não existir dúvida de que o emprego é uma variável fundamental para descrever a importância econômica do turismo (IPEA, 2003, p.6).

Outro aspecto de dificuldade no estudo desse tema advém,

[...] principalmente, da definição de quais são as atividades características que compõem o turismo e do grau de detalhamento dos códigos de atividade com que cada uma dessas fontes trabalha. Não existindo condições de distinguir de forma 
precisa, nessas classificações, quais unidades (pessoas e estabelecimentos) prestam serviços aos visitantes e quais não, torna-se impossível chegar a uma quantificação unanimemente aceita a respeito das dimensões ocupacionais e dos rendimentos do turismo nacional (IPEA, 2003, pp. 9-10).

Analisando mais detidamente os dados da pesquisa em análise podemos perceber que, dentre os principais atributos demográfico-educacionais analisados, os que mais se destacaram são: o percentual de empregados do sexo masculino; o percentual de empregados jovens, com idades entre 10-24 anos e; o percentual de empregados com educação fundamental incompleta.

Quanto ao primeiro item, o texto indica um sistemático retrocesso do emprego masculino. Já quanto aos jovens de 10-24 anos no mercado formal, observa-se uma tendência praticamente estável em todos os universos, sendo que o setor Alimentação exibe as percentagens mais elevadas de contratação de jovens como mão-de-obra formal.

Com relação ao perfil educacional, a educação fundamental incompleta, ou menor diminuiu mais de dez pontos percentuais. No setor Alimentação, a título de exemplificação, essa percentagem passou de 58,0\%, em 1995, para 38,4\%, em 2001.

Todavia, o estudo aponta que a evolução dos salários reais, no período estudado, demonstra que esses ganhos de produtividade não se traduziram em avanços na remuneração dos empregados.

Quanto às condições trabalhistas foram destacados três aspectos: percentagem do emprego em estabelecimentos com até 100 empregados; percentagem do emprego formal com duração inferior a um ano e; percentagem de emprego com contrato de trabalho de até 40 horas semanais.

Referente ao primeiro item, especificamente, observa-se que a presença de estabelecimentos de pequeno e médio porte é mais marcante nos setores de Alojamento e Alimentação. Já com relação à percentagem do emprego formal com duração inferior a um ano, o estudo destaca que a componente Alimentação acaba definindo uma maior rotatividade do emprego formal.

Em análise aos diferenciais geográficos, o texto aponta que o emprego formal nas atividades turísticas tem peso maior no Rio de Janeiro, Espírito Santo e Bahia, e que a participação das ocupações turísticas nos estados em que ela é mais importante - Bahia e Rio 
de Janeiro - situa-se em torno do dobro daquela apresentada nos estados onde o emprego turístico tem menor expressão - Piauí e Tocantins.

Quanto à distribuição do emprego formal nas atividades turísticas observa-se que São Paulo concentra $30 \%$ dos empregos no grupo denominado 'turismo amplo' e $26 \%$ do grupo denominado 'Núcleo Duro do Turismo'?

Ainda segundo os autores, os resultados verificados podem, em parte, estar associados aos dados da PNAD, no período entre 1995 a 2001, que apontam para um medíocre desempenho da economia nacional.

Embora o quadro econômico tenha se mostrado desfavorável, no período citado, as análises dos números da PNAD apontam para um

[...] avanço da terceirização das atividades econômicas [...] com 821,8 mil (84,6\%) das 971,6 mil novas ocupações criadas anualmente no país nesse período, equivalentes a um incremento de $3,0 \%$ a.a. [...]. Por sua vez, o crescimento ocupacional do conjunto dos quinze ramos selecionados nessa fonte para compor o turismo foi ainda mais expressivo, alcançando uma média de incremento anual de 173,1 mil novas ocupações [...]. Ou seja, o turismo, na PNAD, elevou a sua participação no contexto ocupacional de 6,5\% em 1995\%, para 7,4\% em 2001 (IPEA, 2003, pp. 21-22)

Porém, quando analisamos mais de perto a qualidade dessa evolução quantitativa do mercado de trabalho no turismo percebemos que os números não são tão positivos. A continuidade do estudo analisado mostrou que,

[...] no setor de serviços e, principalmente no turismo, a evolução ocupacional foi favorecida, principalmente pela expressiva expansão das ocupações não formais [...]. O emprego formal cresceu a uma taxa de $2,5 \%$ a.a., ao passo que as ocupações não formais aumentaram em 3,3\% a.a. [...]. No turismo, onde foram criados 173 mil novas ocupações/ano, apenas $44 \mathrm{mil}$ delas corresponderam a empregos formais (IPEA, 2003, pp. 21-22).

9. A expressão entre aspas, denominada 'Núcleo Duro do Turismo', corresponde a um grupo específico de atividades do setor turismo, onde os níveis de atendimento a turistas estão entre os maiores do setor. Compõem este seleto grupo as empresas de transporte aéreo, agências de viagem e hospedagem. $\mathrm{O}$ turismo amplo, por sua vez, refere-se ao conjunto de todas as ACTs. 
Além dessa perspectiva, a situação do emprego no turismo também mostrou-se decepcionante quanto à evolução dos rendimentos médios, quando comparado com a totalidade dos setores da economia, inclusive com o setor de serviços. No período analisado, o turismo apresentou perda real nos rendimentos médios de $13,2 \%$, enquanto que a totalidade da economia e o setor de serviços apresentaram perdas de 5,5\% e 5,7\%, respectivamente (IPEA, 2003, pp. 21-22).

Analisando os dados da RAIS, no período estudado, observa-se uma boa aproximação com os dados apontados pela PNAD. Enquanto a PNAD reconhece a criação média anual de 44 mil novas ocupações (2,28\% a.a), a RAIS aponta para a criação de 37 mil (2,27\% a.a), sendo que ambas demonstram "uma baixa capacidade do setor para criar emprego formal, principalmente quando comparada com as oportunidades de ocupação não formal que o mesmo setor gerou entre 1995 e 2001” (IPEA, 2003, p.26).

Os números da RAIS também permitem avaliar que os diferentes setores que compõem o turismo apresentaram trajetórias muito diferentes:

[...] enquanto a alimentação apresentou uma taxa de crescimento médio anual do emprego formal de $5,6 \%$, chegando a ser responsável por quase $70 \%$ do total do emprego criado pelo turismo no período, o emprego no alojamento cresceu em 3,4\% e o correspondente aos transportes em apenas $0,8 \%$. [...] Cabe apenas destacar que as agências de viagem foram as únicas que tiveram um decréscimo de emprego formal entre 1995 e 2001, sendo que grande parte dos 11,8 mil empregos perdidos ocorreram nos anos 1998 e 1999, período em que a economia apresentou o mais baixo crescimento (o PIB real cresceu em $0,22 \%$ e $0,79 \%$, respectivamente), com o agravante da forte desvalorização do Real (R\$), ocorrida em inícios de 1999 (IPEA, 2003, pp. 27-28).

Outro importante aspecto em que os dados da PNAD e da RAIS parecem convergir refere-se à perda salarial, conforme trecho extraído a seguir.

As perdas acumuladas alcançaram, respectivamente, $3,7 \%$ e $5,4 \%$ no setor de serviços e no turismo, sendo mais acentuada nos outros dois universos, onde o poder aquisitivo dos salários retrocedeu em 9,2\% no núcleo duro e 9,3\%, no núcleo duro + alimentação, nos 6 anos pesquisados. Sublinha-se que, no caso do universo turismo, a perda do poder de compra dos salários aconteceu apesar dos salários reais das 
componentes alimentação e, principalmente, alojamento mostrarem ganhos significativos (IPEA, 2003, pp. 27-28).

Embora estejamos retratando as perdas salariais, chama atenção o comportamento diferente, entre os diferentes setores que compõem o turismo, reforçando o fato de que, talvez os diferentes setores precisem ser analisados individualmente, quando se almeje um entendimento mais aprofundado de cada setor em específico.

Já nas suas conclusões, esse estudo aponta que: "mais de dois terços das ocupações geradas estão relacionadas à alimentação (28,6 mil empregos ano) e ao transporte urbano de passageiros (48,5 mil ocupações ano), sendo que nas duas atividades, apenas uma parcela está vinculada ao atendimento de turistas". Além disso, "mais de $75 \%$ das ocupações geradas no turismo amplo, no período, ocorreram no mercado não formal” (IPEA, 2003, p. 36).

Sob vários aspectos observa-se uma evolução muito diversa nas diferentes atividades que compõem o turismo. "Enquanto no segmento formal dos setores alojamento e alimentação registraram acréscimos de 8,9\% e 6,6\% no rendimento mensal, [...] nos setores de transportes, agências de viagem, cultura e outros ocorreram sensíveis perdas de rendimento. Para o conjunto das atividades que compõem o núcleo duro, essa perda foi da ordem de $10 \%$ " (IPEA, 2003, p. 37).

Para finalizar, a análise do desse trabalho realizado pelo IPEA, destacamos a seguinte passagem que diz que,

[...] diante da expectativa do governo de geração de mais e melhores empregos no turismo, a evolução observada neste estudo pode ser considerada decepcionante, tanto em termos de ritmo de crescimento quanto da qualidade dessa ocupação. Isso porque, não obstante a melhora do perfil educacional dos empregados formais no turismo, as ocupações criadas ocorreram, principalmente, fora das atividades mais estreitamente vinculadas ao turismo, se deram dentro do segmento não formal e foram acompanhadas de uma deterioração dos rendimentos mais forte do que a verificada no setor serviços (IPEA, 2003, p. 37).

Ao término da análise destes primeiros textos podemos observar que as diferentes características, por ora apresentadas e que dão forma ao mercado de trabalho no turismo, como: aumento da informalidade, perdas salariais importantes, baixo índice de geração de 
vagas de trabalho, rotatividade, etc., originam-se das características do modus operandis do próprio turismo enquanto atividade econômica.

Com essa perspectiva acreditamos que, ao revelar os principais aspectos e evolução do trabalho no turismo, estaremos revelando, de fato, partes importantes do próprio turismo, enquanto atividade econômica, ou mesmo como prática social.

Em sequência à análise dos demais textos produzidos pela parceria, podemos visualizar alguns resultados da pesquisa, que trazem ainda informações sobre atributos individuais e ocupacionais - como gênero, idade, escolaridade, tempo de emprego, remuneração, tamanho do estabelecimento, entre outros. Além de apresentar também dados relativos a ocupações mais frequentes em atividades que constituem o núcleo do turismo e dos diferentes aspectos referentes às demais atividades características do turismo (ACTs).

Os textos citados, quando analisados em conjunto, possibilitam uma proposta metodológica para a produção de indicadores sobre o mercado de trabalho no setor turismo, por meio de fontes secundárias de cobertura nacional.

Durante a análise do primeiro texto realizado pelo IPEA, no âmbito da parceria MTur - IPEA, podemos perceber certas críticas sobre a inexistência da definição de quais são as atividades características que compõem o turismo, e a não existência de condições para distinguir de forma precisa, quais unidades (pessoas e estabelecimentos) prestam serviços aos visitantes e quais não.

Diante de tal dificuldade inicial, em 2004 o IPEA publicou o documento "Proposta metodológica para a produção de indicadores correntes sobre o mercado de trabalho no setor turismo, por meio de fontes secundárias de cobertura nacional”, que estabeleceu uma "proposta relativa ao aproveitamento das fontes secundárias de cobertura nacional, para gerar dados e indicadores contínuos diretos sobre o mercado de trabalho no setor turismo" (IPEA, 2004, p.6).

Cabe frisar que antes da confecção deste material não havia uma linha própria de trabalho para estudar o trabalho no turismo, cabendo a cada autor ou a cada estudo propor seus caminhos e definições.

Este documento, no entanto, se propõe a discutir detalhadamente o uso da Relação Anual de Informações Sociais - RAIS, para quantificar o emprego formal do setor turismo, 
bem como o uso do Cadastro de Estabelecimentos Empregadores - CEE, do Ministério do Trabalho e Emprego - MTE, para a estruturação do universo de uma amostra a ser pesquisada por telemarketing, para propor o cálculo de coeficientes de atendimento turístico/residente.

Seguindo orientação da OMT, as indústrias turísticas devem ser definidas como todos os estabelecimentos cuja atividade produtiva principal é uma "atividade característica do turismo". A lista dessas atividades reconhece 12 itens:

\section{Hotéis e similares}

2. Segundas vivendas em propriedade

3. Restaurantes e similares

4. Serviços de Transporte de passageiros por ferrovia

5. Serviços de Transporte de passageiros por rodovia

6. Serviços de Transporte marítimo de passageiros

7. Serviços de Transporte aéreo de passageiros

8. Serviços conexos ao Transporte de passageiros

9. Arrendamento de bens e equipes de transporte de passageiros

10. Agências de viagens e similares

\section{Serviços Culturais}

12. Serviços desportivos e outros de lazer

Além disso, o referido documento "tece também considerações a respeito das possibilidades de estender essas medições ocupacionais ao segmento não formal da economia turística, valendo-se da Pesquisa Nacional por Amostra de Domicílios - PNAD, do IBGE. Essa complementação é importante em virtude da forte incidência de ocupações não formais no setor" (IPEA, 2004, p.6).

Por último, o documento também discute a possibilidade de utilização do Cadastro Geral de Empregados e Desempregados - CAGED, do MTE, para dispor, mensalmente, de indicadores mais atualizados sobre a conjuntura do mercado de trabalho no setor turismo.

Assim, pode-se dizer que os estudos para análise e o entendimento da força de trabalho empregada no setor do turismo no Brasil entrou em uma nova fase, com uma formatação melhor estruturada e contando com uma metodologia própria. 
Outro estudo em destaque "Caracterização da mão-de-obra formal do setor turismo com estimativas baseadas nos dados da RAIS de 2004", trazido ao público em 2006, trata das características da mão-de-obra formal a partir das análises dos dados da RAIS, correspondentes a 31 de dezembro de 2004. Nele podemos identificar as "características demográficas-educacionais, ocupacionais e de remuneração da mão-de-obra formal empregada" no setor do turismo (IPEA, 2006, p. 4).

O estudo seguinte, "Caracterização da mão-de-obra informal do setor turismo, com estimativas baseadas nos dados da PNAD de 2005" trazido ao público no ano seguinte, em 2007, procura realizar percurso semelhante ao anterior, porém retratando a mão-de-obra informal no setor, que de tão numerosa requer estudos e análises à parte. Para tanto, este estudo lançou mão de dados da PNAD, enquanto que, para análise da mão-de-obra formal a metodologia do IPEA faz uso dos dados da RAIS.

Vale aqui destacar que, em geral, os estudos do IPEA utilizam-se prioritariamente da RAIS e CAGED (MTE) e PNAD (IBGE), que são fontes secundárias de dados, de cobertura nacional, que apresentam informações sobre a realidade ocupacional do país.

Ainda em 2007, o IPEA produziu outro importante estudo: "Evolução da remuneração da mão-de-obra formal das principais atividades características do turismo, para o Brasil e estados - janeiro de 2003 a dezembro de 2006”. Por meio deste estudo foi possível apresentar uma síntese sobre a evolução do total nacional dos vínculos celetistas no período (média mensal em cada ano), bem como a comparação de resultados sobre as remunerações médias, no mesmo período.

No ano seguinte, em 2008, o IPEA editou outro estudo da mesma série em questão: “Caracterização da ocupação formal no turismo, com base nos dados da RAIS de 2002 e 2006, e da ocupação informal no turismo, com base na PNAD de 2002 e 2006." Por meio deste material, redigido em duas partes distintas, observa-se de forma mais acurada as mudanças qualitativas dos aspectos demográficos, ocupacionais e de rendimentos, ocorridas no período analisado (2002 a 2006), levando em conta a mão-de-obra formal e informal.

Na sequência do conjunto de estudos do IPEA, no ano de 2013 são trazidos ao público simultaneamente dois trabalhos, o " $4^{\circ}$ Relatório com a caracterização da ocupação formal do turismo, no Distrito Federal, com base nos dados da RAIS" e o; "4º Relatório com a caracterização da ocupação informal do turismo, na região Centro-Oeste, com base nos dados da PNAD”. 
Uma importante característica desses textos refere-se à incorporação de alterações na metodologia do IPEA, notadamente quanto às atualizações dos coeficientes de atendimento ao turista e alterações nas chamadas Atividades Características do Turismo - ACTs, que passam a incorporar mudanças sugeridas pela Organização Mundial do Turismo.

Uma das inovações introduzidas na metodologia foi a desagregação da ACT Transporte, que passou a ser dividida em três subatividades: Transporte Aéreo, Transporte Terrestre e Transporte Aquaviário, com a exclusão do transporte urbano, onde, segundo os coeficientes de atendimento ao turista, haveria uma participação pouco significativa de trabalhadores que atendem apenas aos turistas, em detrimento da população local.

No ano seguinte, em 2014, a série metodológica do IPEA emite dois novos documentos, que dão continuidade aos dados analisados quanto à mão-de-obra formal e informal, tanto para o Centro-Oeste, quanto para o Distrito Federal. São eles: o " 5 Relatório com a caracterização da ocupação informal do turismo, na região Centro-Oeste, com base nos dados da PNAD" e o; "5 Relatório com a caracterização da ocupação formal do turismo, no Distrito Federal, com base nos dados da RAIS".

Os estudos datados de 2013 e 2014, por serem elaborados de forma contínua e adotando a mesma metodologia, permitem um quadro comparativo dos dados sobre o trabalho no turismo naquela região em análise. Esta série será complementada por outro estudo realizado no ano seguinte, em 2015. Naquele ano o IPEA publica o estudo "Caracterização da mão-de-obra formal ocupada nas Atividades Características do Turismo no Distrito Federal (Dados 2013)", que permite a ampliação da análise dos dados do trabalho no turismo, tanto no tempo (2011, 2012 e 2013), quanto no espaço (Distrito Federal).

O último documento da série histórica do IPEA, que procura caracterizar a mão-deobra do setor turismo foi publicado em 2015, sob o título: "Relatório com as estimativas da caracterização da ocupação formal e informal do turismo, com base nos dados da RAIS e da PNAD 2013, para o Brasil e regiões”.

Este documento utiliza-se dos dados da RAIS e da PNAD no ano de 2013 retratando o Brasil e suas regiões. O mesmo pode ser entendido com uma sequência do documento publicado em 2008, que retrata as características da mão-de-obra formal e informal para o período entre 2002 a 2006. Muito embora, haja alterações importantes entre os dois 
documentos citados, em razão de que no ano de 2009 o IPEA promoveu alterações na forma de produção dos estudos em questão.

A apresentação dos estudos produzidos pelo IPEA, bem como uma breve exposição de seus principais resultados permitem atestar o potencial deste material para o estudo do trabalho no setor.

Agora, a partir do próximo item, poderemos avançar nossas análises e tecer considerações ao longo de um período relativamente longo e contínuo (2003 a 2015), destacando a distribuição espacial do trabalho no setor, bem como a análise dos principais aspectos ocupacionais do trabalho no turismo. 


\subsection{As características da força de trabalho no turismo no Brasil}

Por tudo o que vimos até aqui, a caracterização da força de trabalho no turismo deve ser considerada como algo complexo, que contém, em si, muitas peculiaridades, haja vista a própria natureza da atividade econômica do turismo, que é marcada por uma acentuada informalidade, sazonalidade e rotatividade tornando-se um dos grandes desafios para o setor e que compromete os serviços oferecidos, em razão do emprego de uma força de trabalho com uma baixa escolaridade, baixa qualificação, baixa remuneração e que, portanto, convive com condições diárias de precariedade no trabalho.

Além das peculiaridades citadas, outras dificuldades surgem para o estudo do trabalho no setor. Quando iniciamos nossos estudos, identificamos que os números apresentados são obtidos a partir do uso de estimativas para a contagem do pessoal empregado, já que não há como se precisar o total de pessoal empregado. Isto porque, como já dissemos antes, nem todas as pessoas que trabalham nas atividades características do turismo atuam diretamente no atendimento a turistas, já que muitos empreendimentos como hotéis, restaurantes, museus, entre outros, também são utilizados por residentes locais.

Outra dificuldade identificada no estudo sobre o trabalho no turismo reside na grande quantidade de atividades desempenhadas pelos trabalhadores que atuam no setor com funções tão variadas como garçons, camareiras, motoristas, agentes de viagens, atendentes, guias turísticos, pilotos de aeronaves, entre muitas outras ocupações. Esta característica confere ao trabalho no turismo uma grande heterogeneidade, tornando mais difíceis as abordagens genéricas e simplificadas.

A informalidade da mão de obra é outra característica marcante do setor e deve ser sempre levada em conta. Conforme os números apontam, podemos dizer, grosso modo, que praticamente metade da população que trabalha no turismo atua sem carteira assinada e, portanto, dificilmente são computadas pelas estatísticas oficiais.

Visando diminuir as distorções de análises provocadas pelas características apontadas apresentaremos alguns dados estatísticos e extrairemos a partir deles algumas análises, que permitem delimitar melhor certos contornos da força de trabalho no turismo.

Esses números foram extraídos dos estudos produzidos pelo IPEA, em parceria com o Ministério do Turismo, conforme previamente apresentado. 
Esses estudos foram produzidos pelo IPEA, em um período que vai de 2003 a 2015 , com base em dados produzidos pelo Ministério do Trabalho (RAIS e CAGED). No entanto, os estudos editados nos anos citados utilizam-se de bases estatísticas produzidas em períodos anteriores, que vão de 2001 a 2013, sendo esta, portanto, nossa base de dados estatísticos.

Por uma questão de método preferimos nos ater ao conjunto de dados do IPEA, pois foram produzidos com uma mesma base metodológica, levando em conta o Coeficiente de Atendimento ao Turista, bem como uma caracterização padronizada do conceito das ACTs, permitindo uma homogeneização dos conceitos utilizados e, consequentemente, dos resultados obtidos.

Portanto, é por meio da utilização dos dados do IPEA, entre 2001 a 2013, que conseguimos identificar uma série de características do trabalho no turismo, não apenas em um dado momento, mas por meio de um conjunto de dados levantados ao longo de uma década de pesquisas sobre o trabalho no setor.

A análise conjunta desses dados nos permitiu destacar um processo contínuo de transformações do trabalho no turismo, como por exemplo, o tão comentado crescimento de vagas de trabalho, bem como características e especificidades tanto espaciais, quanto no interior do setor turismo, pois como já dissemos, é composto por um mosaico de atividades e subsetores da economia com acentuada heterogeneidade.

Para melhor ilustrar estes aspectos do trabalho no turismo iniciaremos, a partir do próximo tópico, uma análise espacial do trabalho no setor, enfatizando sua distribuição no território brasileiro, bem como suas características regionais e por estados.

Por meio desta análise poderemos investigar os seguintes aspectos:

I. Distribuição espacial da força de trabalho no turismo:

a) Pessoal ocupado - Brasil, regiões e estados;

b) Atividades Características do Turismo - ACTs;

c) Índice de Dependência do Turismo.

Em seguida, nosso percurso de método irá nos direcionar para análises dos principais aspectos ocupacionais do trabalho no turismo, onde iremos enveredar análises sob os seguintes pontos:

II. Aspectos ocupacionais do trabalho no turismo: 

a) Faixas salariais;
b) Tempo no emprego (rotatividade);
c) Jornada de trabalho (horas semanais);
d) Tamanho dos estabelecimentos;
e) Nível de Escolaridade.

\subsubsection{Distribuição espacial do trabalho no turismo}

\section{a) Pessoal ocupado no Brasil, regiões e estados}

A análise da distribuição espacial do trabalho no turismo é fundamental para o entendimento do próprio turismo no Brasil, "tendo em vista que o turismo é largamente dependente do território" (IPEA, 2015b, p.7).

No entanto, por tudo o que vimos até o presente momento, muitas são as possibilidades de análise da distribuição do trabalho no turismo. Podemos analisar a distribuição geral dos trabalhadores no território nacional, nas regiões do país, nos estados, nos municípios, ou empreender abordagens mais específicas, como veremos a seguir.

Uma das análises possíveis refere-se ao número de pessoal empregado no turismo por um determinado período, bem como o crescimento dessa população ao longo do tempo, e até mesmo a distribuição espacial e características principais relativas a esta distribuição.

Partindo desses aspectos mais relevantes, podemos iniciar nossas reflexões por meio do estudo do IPEA denominado "Estimativas anuais da mão-de-obra informal ocupada em atividades características do turismo, tendo por base os resultados da Pesquisa Nacional por Amostra de Domicílios - PNAD -, no período 2002 A 2005." Este trabalho, publicado em 2007, possibilita uma boa análise de conjunto do total de pessoas ocupadas no turismo no Brasil em um determinado período de tempo. Por meio desses dados podemos identificar que a quantidade de postos de trabalho era de 1.477 mil em 2002 e saltou para 1.617 mil em 2005, gerando 139 mil novas ocupações em 3 anos. Outro importante dado apontado refere-se à informalidade no setor, que por sua vez desponta como um aspecto dominante, saltando de 843 mil ocupações em 2002, para um total de 929 mil em 2005, com elevada participação, representando $57 \%$ dos postos de trabalho (IPEA, 2007c, pp. 22-25).

Em sequência à série de dados sobre o crescimento do pessoal empregado no turismo apresentaremos os números do relatório "Estimativas referentes à dimensão da mão-de-obra informal nas atividades características do turismo com base nos dados da PNAD 2006, para o 
Brasil, regiões e estados" (IPEA, 2008b), onde podemos identificar um aumento de 4,2\% nos postos de trabalho em 2006, comparado com o ano anterior, perfazendo um total de 1.683,7 (mil). Neste total destaca-se, mais uma vez, a presença da mão-de-obra informal, com 955,7 mil, com o mesmo percentual de $57 \%$, conforme pode ser observado na tabela 1 .

Tabela 1. Crescimento da mão-de-obra no turismo: 2002 - 2013 (em milhões)

\begin{tabular}{|c|c|c|c|c|c|c|c|c|c|c|c|c|}
\hline & \multicolumn{2}{|c|}{2002} & \multicolumn{2}{c|}{2003} & \multicolumn{2}{c|}{2004} & \multicolumn{2}{c|}{2005} & \multicolumn{2}{c|}{2013} \\
\hline Formal & 634.324 & $43 \%$ & 639.590 & $42 \%$ & 657.846 & $43 \%$ & 687.636 & $43 \%$ & 728.000 & $43 \%$ & 985.317 & $51 \%$ \\
\hline Informal & 842.864 & $57 \%$ & 867.728 & $58 \%$ & 886.031 & $57 \%$ & 928.901 & $57 \%$ & 955.700 & $57 \%$ & 953.638 & $49 \%$ \\
\hline Total & 1.477 .188 & & 1.507 .318 & & 1.543 .877 & & 1.616 .537 & & 1.683 .700 & & 1.938 .955 & \\
\hline Crescimento & $100 \%$ & & $102,0 \%$ & & $102,4 \%$ & & $104,7 \%$ & & $104,2 \%$ & & $115,2 \%$ & \\
\hline
\end{tabular}

Fonte: IPEA, 2015, 2008b e 2007c. Organizado pelo autor, 2018.

Para complementar a série de dados referentes ao pessoal empregado no turismo, vamos utilizar os dados do "Relatório com as estimativas da caracterização da ocupação formal e informal do turismo, com base nos dados da RAIS e da PNAD 2013, para o Brasil e regiões" (IPEA, 2015), que aponta que a atividade do turismo era responsável por aproximadamente 1,938 milhões de ocupações no Brasil. Sendo 985 mil (51\%) empregos formais e 954 mil, informais (49\%).

Em análise aos dados apresentados na tabela 1 podemos perceber o crescimento percentual registrado no período estudado. Quando tomamos o ano de 2002 como base, podemos identificar um crescimento de $2 \%$, em 2003 e de 2,4\%, no ano seguinte. No período posterior, em 2005, podemos identificar um crescimento de 4,7\%, em relação a 2004, enquanto que, em 2006, um crescimento de 4,2\%, em relação a 2005.

Ao avançarmos na análise dos dados verificamos que, no ano de 2013 ocorre um crescimento de $15,2 \%$ sobre o ano de 2006, revelando um crescimento anual de aproximadamente $2 \%$ ao ano, no período de sete anos.

Ainda quanto aos dados apresentados para o ano de 2013, percebemos que houve uma alteração na composição dos trabalhadores formais e informais, com um gradual aumento dos trabalhadores formais em relação aos trabalhadores informais do turismo. Pelos dados apresentados, os trabalhadores formais no período somavam 985.317 postos de trabalho, perfazendo $51 \%$, enquanto que os informais perfaziam um total de 953.638 trabalhadores $(49 \%)$. 
Estes números revelam dois importantes aspectos: o percentual de crescimento do trabalho no turismo durante o período estudado, bem como a importante participação do trabalho informal no setor.

Quanto ao crescimento da mão-de-obra no turismo devemos compará-la com o crescimento da economia como um todo, para podermos entender melhor a dimensão real do crescimento apontado no setor.

Segundo Árias, no período entre 2002 a 2006, a mão-de-obra formal, apresentou um aumento de 100 mil novos empregos, com uma taxa de crescimento médio de 3,5\% a.a., embora o total de novos empregos para o total de celetistas para o mesmo período tenha apresentado um crescimento médio anual de 5,4\%. Ou seja, enquanto o turismo cresceu 3,5\%, a economia como um todo cresceu a patamares superiores. Quanto à mão-de-obra informal também se observa um aumento, porém mais modesto com 78,8 mil novos empregos, com uma taxa de crescimento médio de 2,3\% a.a. Este aumento apresentou uma evolução do segmento informal do turismo em torno de $1,6 \%$, ficando praticamente inalterado, quando comparado com o total informal da economia (IPEA, 2008, pp.16 - 17).

Os números de 2013 apontam ainda que, com o total de 1,938 milhões de trabalhadores "essa ocupação representa cerca de 2,2\% da ocupação da economia como um todo no país. Os empregos formais do turismo representam 2,5\% do total de empregos formais da economia e os informais, 1,9\%" (IPEA, 2015, p. 13).

Os números apresentados até o momento mostram que o trabalho no turismo apresentou um crescimento entre 2,5 a $3 \%$ ao ano e que este crescimento apresenta-se, em geral, inferior ao crescimento da economia, situando-se entre 1,9 a 2,2\% do total de empregos na economia como um todo.

Estes dados atenuam relativamente o propalado entusiasmo referente ao crescimento do emprego no turismo, já que os números no setor apontam para um crescimento que acompanha, embora a patamares inferiores, o desempenho da economia como um todo. $\mathrm{Ou}$ seja, percebemos que o emprego no turismo cresce, quando a economia também cresce.

Outro relevante aspecto refere-se ao elevado percentual de mão de obra informal, que embora tenha apresentado um declínio ao longo do período estudado, ainda se encontra em patamares próximos a $50 \%$ do mercado de trabalho no setor.

Avançando na análise da distribuição espacial do trabalho no turismo apresentaremos os dados extraídos do estudo "Mensurando o emprego no setor turismo no Brasil: do nível nacional ao regional e local.” (IPEA, 2015), que expressa os números de empregos no turismo por Unidades da Federação, com base nos dados da RAIS, para o ano de 2010. 
Os dados obtidos podem ser visualizados por meio do mapa 1, relativo ao número de empregos no turismo por estado.

Mapa 1. Brasil 2010: número de empregos no turismo por estados

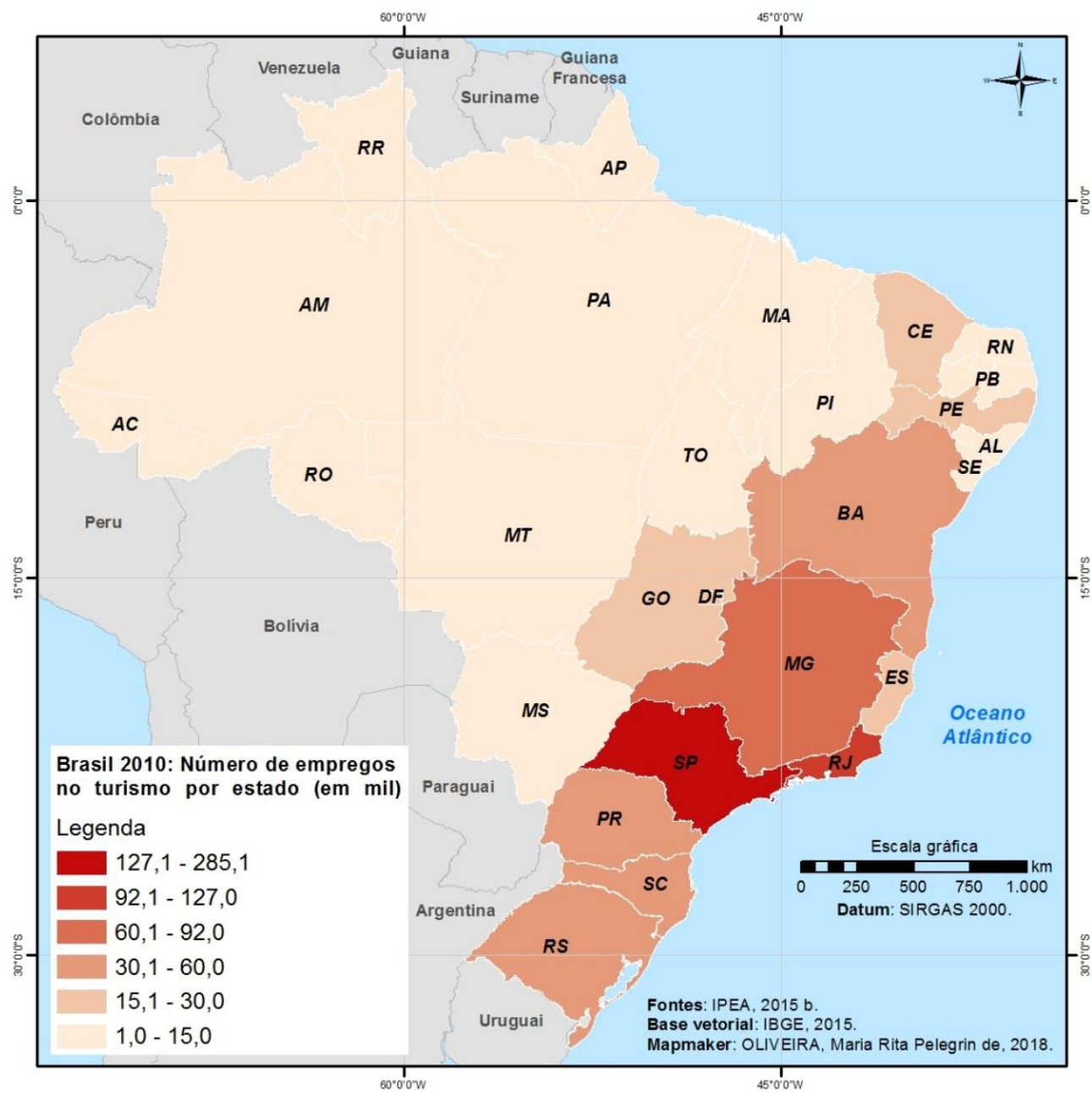


Os dados mapeados sinalizam uma importante concentração de pessoal empregado nos estados do Sudeste, principalmente em São Paulo, com 285,1 mil trabalhadores (32\%), Rio de Janeiro, com 126,3 mil trabalhadores (14\%) e Minas Gerais, com 91,4 mil trabalhadores $(10,2 \%)$. Os três estados citados são responsáveis por mais de $56 \%$ do pessoal empregado no país.

Em um segundo patamar destacam-se os estados do sul do país, como o Rio Grande do Sul, com 47,6 mil trabalhadores formais (5,3\%), Paraná, com 47,2 mil (5,3\%) e Santa Catarina, com 34 mil (3,8\%). Além de alguns estados do Nordeste, como Bahia, que aparece na quinta posição, com 47,2 mil trabalhadores formalizados (5,3\%), Pernambuco, com 28,7 mil (3,2\%) e Ceará, com 20,9 mil (2,3\%). Perfazendo as dez maiores Unidades da Federação, em número de empregos formais no turismo devemos incluir também o Distrito Federal, com 21,8 mil trabalhadores $(2,4 \%)$.

As demais Unidades da Federação somadas congregam 140 mil trabalhadores, ou seja, apenas $15,7 \%$ do total de 890,3 mil trabalhadores no turismo, para o ano de 2010.

Ainda quanto à distribuição espacial do trabalho no turismo por regiões do país, segundo o IBGE, em dezembro de 2013, a região Sudeste respondia por 51\% das ocupações no setor turismo, seguida pela Região Nordeste, com 23\%; a Sul, com 13\%; e, no mesmo patamar, as Regiões Norte e Centro-Oeste, com 7\%, conforme exposto na tabela 2 (IPEA, 2015, p. 14).

Tabela 2. Trabalho no turismo: distribuição percentual por regiões (2011)

\begin{tabular}{|c|c|c|}
\hline Regiões & $\begin{array}{c}\text { Trabalho no Turismo } \\
\text { (Formal e Informal) } \%\end{array}$ & $\begin{array}{c}\text { Trabalho no Turismo } \\
\text { (somente Formal) } \%\end{array}$ \\
\hline Sudeste & 51 & 58 \\
\hline Nordeste & 23 & 17 \\
\hline Sul & 13 & 15 \\
\hline Centro-Oeste & 07 & 07 \\
\hline Norte & 07 & 04 \\
\hline
\end{tabular}

Fonte: IPEA, 2015. Organizado pelo autor, 2018. Observação: valores arredondados, soma excede 100\%. 
Esta distribuição, por si, já é de todo reveladora da concentração do trabalho no turismo, permitindo identificar a enorme disparidade regional, com expressiva participação da Região Sudeste, em detrimento das demais.

Porém, quando analisamos a distribuição somente da mão-de-obra formal encontramos um resultado que reforça a concentração existente. O Sudeste participa com $58 \%$ dos empregos formais das ACTs, e o Nordeste, com apenas 17\%; o Sul, com 15\%; o CentroOeste, com 7\%; e o Norte, com 4\%, conforme demonstrado na tabela 2.

Quanto aos números da mão-de-obra formal, encontramos uma maior concentração nos estados do Sudeste, que aumentam sua participação de 51\%, para 58\% (07 p.p.), bem como um aumento da participação da região Sul, de 12\%, para 15\% (03 p.p.), enquanto que os dados para a Região Centro-Oeste mantêm-se inalterados em 7\%. Por outro lado, ocorre situação inversa nos estados das Regiões Norte e Nordeste. A Região Nordeste tem redução de sua participação de $23 \%$, para $17 \%$, enquanto que a Região Norte tem redução de sua participação de $7 \%$, para $4 \%$.

Quanto a essa concentração do trabalho no turismo Coelho e Sakowski concluem que,

[...] em geral, é o desenvolvimento que induz o turismo. A concentração de capital, observada especialmente na região Sudeste, que detém $43 \%$ dos ocupados na economia, replica-se de forma mais intensa no setor turismo, que possui $51 \%$ das suas ocupações nesta região (IPEA, 2014, p.14).

É mister reconhecer, portanto, que o trabalho no turismo revela-se altamente dependente do território, bem como da concentração de capitais, seus fluxos e seus fixos, já que é no Sudeste que se localizam maiores contingentes da população, a maior renda, bem como a maior infraestrutura para o turismo, com portos, aeroportos, hotéis, rodovias, restaurantes, agências de viagens, entre outros importantes serviços.

A esse respeito, Cruz enfatiza que,

[...] quando o turismo, como atividade organizada, começa a se desenvolver no Brasil, principalmente a partir do século XX, é sobre um território já marcado por profundas desigualdades socioespaciais que isto se dará. [...] Que a atividade não apenas será condicionada por esse legado histórico, mas ela mesma se constituirá, no tempo e no espaço, como condicionante de sua reprodução (CRUZ, 2018). 
Ainda quanto à distribuição territorial da mão-de-obra formal e informal no turismo é importante destacar a contribuição de Meliani (2012), que contribui com o entendimento do fenômeno referente à proporção de trabalho formal e informal por estado, conforme pode ser percebido no mapa 2, onde percebe-se a grande concentração de mão de obra informal, principalmente nos estados do Norte e Nordeste.

Conforme procuramos salientar, a evidente concentração espacial do trabalho no turismo no Brasil parece contradizer a lógica de que o turismo possibilita a criação de trabalho de forma generalizada. Pois o que se percebe é a existência de maior aglomeração de postos de trabalho nas regiões mais adensadas, principalmente no Sudeste e Sul do país.

Conforme veremos à frente, a concentração espacial e a informalidade, características marcantes do trabalho no turismo, reveladas até o presente momento, se somarão a outros aspectos ocupacionais e conformarão marcas significativas ao trabalho no turismo. 
Mapa 2. Brasil 2006: proporção de trabalho formal e informal por estado

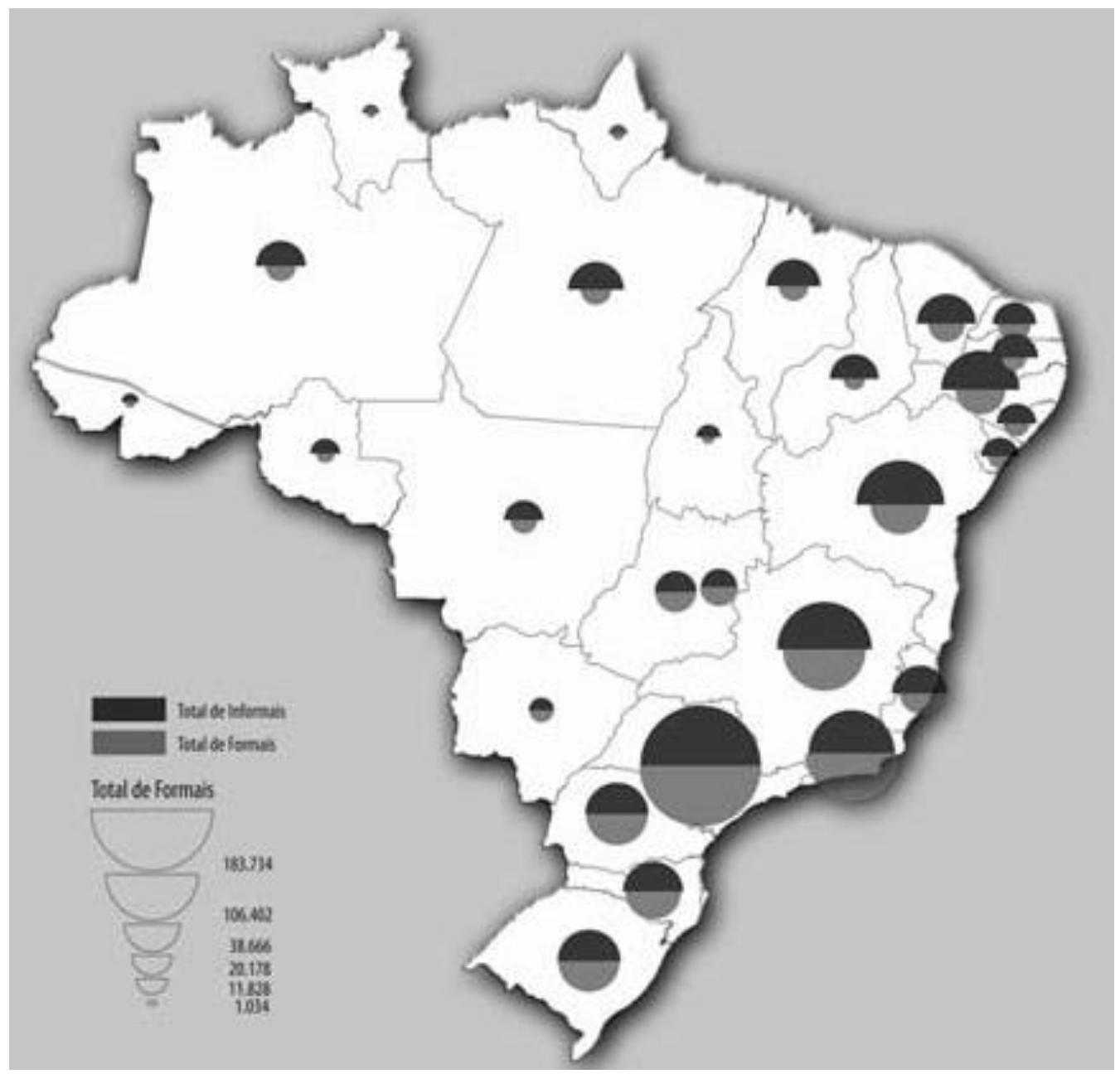

Fonte: IPEA, 2007, Meliani, 2012. Elaborado por Ludmila Girardi Alves. 


\section{b) Atividades Características do Turismo - ACTs}

Mas além da concentração e da informalidade do trabalho no turismo, existem outras importantes possibilidades de análises quanto à população empregada no turismo.

Uma dessas possibilidades recai sobre a análise das diferentes ACTs que compõem o setor.

Como já exposto, uma das importantes características do turismo é a variada composição de setores ou atividades, que atuam de forma interdependente para atendimento ao turista e suas diferentes necessidades. Setores como Transportes, Alojamento, Alimentação, Agências de Viagem, Cultura e Lazer, entre outros, configuram-se nas chamadas Atividades Características do Turismo - ACTs. Estas atividades características, por sua vez, apresentam certas especificidades enquanto ramo de atividade, embora atuem de forma conjugada no interior do setor turismo.

Em nosso entender, todo estudo sobre o trabalho no turismo deverá levar em conta tais especificidades, aprofundando-se em um, ou outro aspecto, sempre que o propósito do trabalho assim o exigir.

Para fins deste trabalho pretendemos, a partir de agora, trazer alguns exemplos gerais das características de algumas das ACTs mais importantes, bem como determinados aspectos de sua distribuição espacial.

Visando iniciar tal análise é necessário, antes de avançarmos, delimitar as ACTs e os contingentes de trabalhadores atuando em cada uma delas.

De acordo com os dados do estudo: "Caracterização da mão-de-obra formal do setor turismo com estimativas baseadas nos dados da RAIS de 2004", os 712,2 mil trabalhadores formais daquele período (2004), eram distribuídos em diferentes grupos de atividades, sendo que o grupo Transporte era o mais numeroso, reunindo 334,5 mil empregos (47\% do total), seguido pelo grupo Alojamento, com 156,4 mil (22\%), o grupo Alimentação, com 127,8 mil (18\%) e o grupo Agências de Turismo, com apenas 34,8 mil trabalhadores formais (4,9\%) (IPEA, 2006, p. 21).

Em outro estudo realizado pouco tempo depois: "Caracterização da ocupação formal no turismo, com base nos dados da RAIS de 2002 e 2006, e da ocupação informal no turismo, 
com base na PNAD de 2002 e 2006”, apresentado ao público em 2008 podemos identificar alguns outros dados importantes e também realizar uma série de análises da mão de obra formal e informal do turismo em um período de tempo contínuo de cinco anos, demonstrando a movimentação de diversos aspectos ocupacionais.

Com base nos dados apresentados na tabela 3 podemos perceber as diferenças de pessoal empregado nas diferentes ACTs que compõe o setor em meados da primeira década do século XXI.

Tabela 3. Trabalho formal e informal nas ACTs: 2002 - 2006 (em mil)

\begin{tabular}{|c|c|c|c|c|c|c|c|c|}
\hline \multirow{2}{*}{ ACTs } & \multicolumn{4}{|c|}{ 2002 } & \multicolumn{4}{c|}{ 2006 } \\
\cline { 2 - 9 } & Formal & Informal & Total & $\%$ & Formal & Informal & Total & $\%$ \\
\hline Alojamento & 148.411 & 49.617 & 198.028 & $13 \%$ & 177.945 & 67.867 & 245.812 & $14 \%$ \\
\hline Alimentação & 111.622 & 297.657 & 409.279 & $27 \%$ & 152.579 & 341.782 & 494.361 & $29 \%$ \\
\hline Transporte & 342.973 & 383.508 & 726.481 & $48 \%$ & 345.666 & 370.209 & 715.875 & $42 \%$ \\
\hline Aux. Transporte & 26.205 & 25.205 & 51.410 & $3 \%$ & 39.141 & 33.846 & 72.987 & $4 \%$ \\
\hline Agências Turismo & 28.950 & 36.946 & 65.896 & $4 \%$ & 39.078 & 55.954 & 95.032 & $6 \%$ \\
\hline Aluguel de Transp. & 6.759 & 2.574 & 9.333 & $1 \%$ & 9.143 & 4.227 & 13.370 & $1 \%$ \\
\hline Cultura e lazer & 18.869 & 47.359 & 66.228 & $4 \%$ & 19.859 & 47.884 & 67.743 & $4 \%$ \\
\hline Totais & $\mathbf{6 8 3 . 7 8 9}$ & $\mathbf{8 4 2 . 8 6 6}$ & $\mathbf{1 . 5 2 6 . 6 5 5}$ & $\mathbf{1 0 0 \%}$ & $\mathbf{7 8 3 . 4 1 1}$ & $\mathbf{9 2 1 . 7 6 9}$ & $\mathbf{1 . 7 0 5 . 1 8 0}$ & $\mathbf{1 0 0 \%}$ \\
\hline
\end{tabular}

Fonte: IPEA, 2008. Organizado pelo autor, 2018.

Com base nos dados citado, podemos destacar inicialmente que a ACT Transporte era a que empregava o maior contingente de trabalhadores, com mais de $40 \%$ de todo pessoal empregado no turismo, enquanto que, na outra ponta da tabela encontramos as ACTs Agência de Turismo, com 6\%, e Cultura e Lazer, com 4\%, que perfazem em conjunto apenas $10 \%$ de todo pessoal empregado no setor.

A segunda maior ACT em número de pessoal empregado é a Alimentação com quase $30 \%$, enquanto que na ACT Alojamento, a terceira mais representativa em termos de pessoal empregado, com um percentual próximo de $15 \%$ do total de pessoal empregado no setor.

Outro importante documento para a caracterização da força de trabalho empregada no turismo refere-se ao estudo: "Relatório com as estimativas da caracterização da ocupação formal e informal do turismo, com base nos dados da RAIS e da PNAD 2013, para o Brasil e regiões" (2015). 
Este material foi entregue ao público em março de 2015 e apresenta algumas diferenciações na metodologia de análise, quando comparado aos documentos anteriormente analisados.

Neste estudo, os resultados relativos à caracterização dos ocupados no turismo são apresentados em oito ACTs: Alojamento, Agências de Viagem, Transporte Terrestre, Transporte Aéreo, Transporte Aquaviário, Aluguel de Transportes, Alimentação e Cultura e Lazer, e não sete, como apresentado até aqui.

As modificações realizadas referem-se ao desmembramento da ACT Transporte em três: Transporte Terrestre, Transporte Aquaviário e Transporte Aéreo, bem como na exclusão da antiga ACT Auxiliar de Transporte.

Estas mudanças fizeram parte de alterações na metodologia do IPEA ao longo do período analisado e refletem as necessidades de ajustes metodológicos para um tema ainda pouco estudado. Os documentos anteriores apresentavam uma composição diferente de ACTs, o que pode ser melhor observado pela análise da tabela 4.

Esta mudança na metodologia quanto à forma de entendimento das ACTs aponta para o fato de que o estudo do trabalho no turismo ainda está em fase inicial de estruturação e que outras mudanças importantes como esta ainda podem ocorrer, tanto na futura redefinição das ACTs, quanto redefinições de metodologias em outras frentes.

Tabela 4. Alteração na composição das ACTs: 2008 / 2015

\begin{tabular}{|c|c|}
\hline $\mathbf{2 0 0 8}$ & $\mathbf{2 0 1 5}$ \\
\hline Alimentação & Alimentação \\
\hline Cultura e Lazer & Cultura e Lazer \\
\hline Aluguel de Transporte & Aluguel de Transportes \\
\hline Transporte & Transporte Terrestre \\
\hline Auxiliar de Transporte & Transporte Aquaviário \\
\hline & Transporte Aéreo \\
\hline Agências de Turismo & Agências de Viagem \\
\hline Alojamento & Alojamento \\
\hline
\end{tabular}

Fonte: IPEA, 2008 e 2015. Organizado pelo autor, 2018.

Outro aspecto importante refere-se à inclusão do conceito de Núcleo do Turismo, ou Núcleo das ACTs, que considera três das ACTs cuja clientela é formada principalmente por 
turistas e não por residentes locais. São elas: Alojamento, Agências de Viagem e Transporte Aéreo (IPEA, 2015, p. 9).

Ainda com relação às ACTs, discorreremos, a partir daqui, sobre seus números, diferenças e características.

Conforme os dados da tabela 5, a ACT Alimentação é a que empregava, em 2011, a maior quantidade de trabalhadores, respondendo por quase $40 \%$ dos empregos no setor, seguida pela ACT Alojamento, com cerca de $24 \%$ e da ACT Transporte Terrestre, com pouco mais de $20 \%$. Estas três ACTs respondem por quase $85 \%$ dos empregos formais no turismo.

\section{Tabela 5. Brasil 2011: participação relativa das ACTs no setor turismo}

\begin{tabular}{|c|c|c|c|c|c|c|c|c|c|}
\hline \multicolumn{10}{|c|}{ Participação relativa das ACTs no setor turismo - Brasil (dez. 2011) } \\
\hline ACTs & Alimentação & Alojamento & $\begin{array}{c}\text { Transporte } \\
\text { terrestre }\end{array}$ & $\begin{array}{l}\text { Transporte } \\
\text { aéreo }\end{array}$ & $\begin{array}{l}\text { Agência de } \\
\text { viagem }\end{array}$ & $\begin{array}{l}\text { Aluguel de } \\
\text { transporte }\end{array}$ & $\begin{array}{c}\text { Cultura e } \\
\text { lazer }\end{array}$ & $\begin{array}{l}\text { Transporte } \\
\text { aquaviário }\end{array}$ & $\begin{array}{c}\text { Todas as } \\
\text { ACTs }\end{array}$ \\
\hline $\begin{array}{c}\text { Número de } \\
\text { ocupações }\end{array}$ & 374.641 & 224.870 & 197.959 & 59.935 & 56.206 & 20.284 & 9.540 & 3.350 & 946.785 \\
\hline $\begin{array}{c}\text { Participação relativa } \\
\text { da ACT (\%) }\end{array}$ & 39,6 & 23,8 & 20,9 & 6,3 & 5,9 & 2,1 & 1 & 0,4 & 100 \\
\hline
\end{tabular}

Fonte: IPEA, 2015. Organizado pelo autor, 2018.

Cabe também destacar que as ACTs Transporte Aéreo, com 6,3\%, e Agências de Viagem, com 5,9\%, quando somadas à ACT Alojamento, com 23,8\%, congregam o chamado Núcleo do Turismo, que é responsável por 36\% dos empregos no setor. Ou seja, é importante frisar que, embora o chamado Núcleo Duro do Turismo seja composto pelas ACTs mais relevantes em termos de atendimento aos turistas, estamos nos referindo a um conjunto de atividades pouco representativo em termos de geração de postos de trabalho no setor.

Este fato é relevante para o entendimento do trabalho no turismo, pois justamente as atividades mais relevantes em termos de atendimento ao turista não são as atividades que mais empregam força de trabalho.

Acreditamos que este aspecto deva merecer uma maior atenção em estudos futuros, pois, como sabemos antecipadamente, as agências de viagem sofreram forte contração de mão de obra em razão do emprego da tecnologia em sites de busca e compra de passagens aéreas e hotéis, enquanto que atualmente as grandes empresas do setor de transporte aéreo e as grandes cadeias de hotelaria internacional têm direcionado suas atenções à análise e revisão das condições de trabalho em seus processos produtivos. Como sabemos, esses estudos organizacionais têm forte caráter economizador de mão-de-obra. 
Retomando às ACTs, devemos ressaltar que o estudo das mesmas é importante para a compreensão das características do trabalho no turismo. As diferenças entre cada uma das ACTs devem ser entendidas por aqueles que pretendem apreender a maneira como o turismo se espacializa.

Assim, empreenderemos uma breve análise sobre a distribuição espacial de algumas ACTs. Entre elas destacamos a ACT Alojamento e a ACT Agências de Viagens, duas ACTs que compõem o Núcleo do Turismo e também a ACT Alimentação, que congrega a maior quantidade de empregos formais.

No que tange à ACT Alojamento, que representava 23\% dos empregos formais no turismo, no ano de 2011, destacamos a concentração dos empregos nos estados de São Paulo, com 40.657 empregos (21,1\%), Rio de Janeiro, com 23.826 empregos (12,4\%) e Minas Gerais, com 17.679 empregos formais $(9,2 \%)$, todos localizados na Região Sudeste.

Outro destaque fica por conta do estado da Bahia, com 18.494 empregos, perfazendo um percentual de $9,6 \%$, do total de empregos formais, ocupando a terceira posição entre os estados com maior quantidade de empregos formais na referida ACT.

Os estados da Região Sul (Paraná, Rio Grande do Sul e Santa Catarina) também ocupam lugar de destaque na ACT Alojamento, sendo que, cada um deles perfaz um percentual de $6 \%$ e ocupam, respectivamente, a quinta, a sexta e a sétima posição.

Os sete estados citados, em conjunto, somam um percentual de $70 \%$ de todos os empregos formais em Alojamento no país, conformando uma concentração espacial dos empregos nesta ACT. 
Mapa 3. Brasil 2008: ACT Alojamento - emprego formal

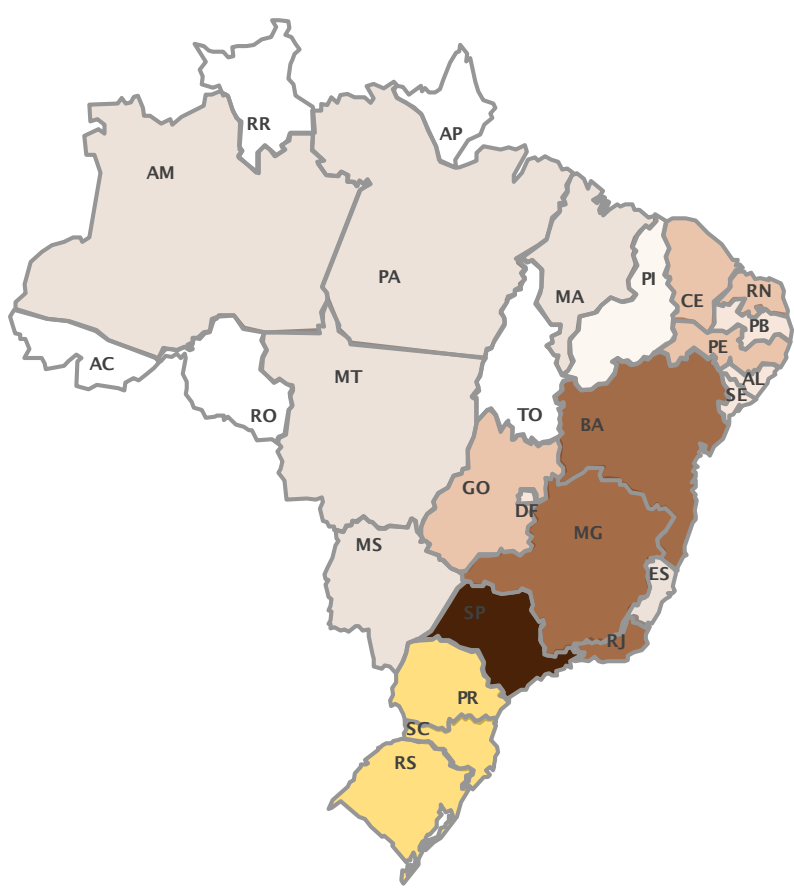

\begin{tabular}{|c|c|r|c|}
\hline & UF & DADOS & $\%$ \\
\hline 1 & SP & 40.657 & $21 \%$ \\
\hline 2 & RJ & 23.826 & $12 \%$ \\
\hline 3 & BA & 18.494 & $10 \%$ \\
\hline 4 & MG & 17.679 & $9 \%$ \\
\hline 5 & PR & 11.679 & $6 \%$ \\
\hline 6 & RS & 11.335 & $6 \%$ \\
\hline 7 & SC & 11.329 & $6 \%$ \\
\hline 8 & PE & 7.600 & $4 \%$ \\
\hline 9 & GO & 6.807 & $4 \%$ \\
\hline 10 & CE & 5.647 & $3 \%$ \\
\hline 11 & RN & 5.612 & $3 \%$ \\
\hline 12 & PA & 3.900 & $2 \%$ \\
\hline 13 & ES & 3.539 & $2 \%$ \\
\hline 14 & AL & 3.321 & $2 \%$ \\
\hline 15 & MS & 2.913 & $2 \%$ \\
\hline 16 & DF & 2.774 & $1 \%$ \\
\hline 17 & MA & 2.466 & $1 \%$ \\
\hline 18 & MT & 2.359 & $1 \%$ \\
\hline 19 & AM & 2.281 & $1 \%$ \\
\hline 20 & SE & 2.110 & $1 \%$ \\
\hline 21 & PB & 2.080 & $1 \%$ \\
\hline 22 & PI & 1.334 & $1 \%$ \\
\hline 23 & RO & 940 & $0 \%$ \\
\hline 24 & TO & 937 & $0 \%$ \\
\hline 25 & AP & 508 & $0 \%$ \\
\hline 26 & AC & 375 & $0 \%$ \\
\hline 27 & RR & 216 & $0 \%$ \\
\hline & & 192.718 & $100 \%$ \\
\cline { 3 - 4 } & & & \\
\hline
\end{tabular}

Fonte: IPEA, 2011. Elaborado pelo autor, 2018. 
A análise da distribuição espacial do trabalho na ACT Agências de Viagem espelha um caso de forte concentração espacial ainda mais expressivo. Quando observamos a distribuição do emprego entre os estados, podemos verificar que somente o estado de São Paulo é responsável por 16.117 empregos formais naquela ACT, o que corresponde a 34,6\% de todos os empregos formais disponível em todas as agências de viagens do país.

O estado do Rio de Janeiro ocupa a segunda posição com 6.500 empregos, o que corresponde a 13,9\%. Portanto, apenas dois estados (SP e RJ) são responsáveis por quase $50 \%$ dos empregos formais nas agências de viagem.

Quando adicionamos os demais estados mais representativos observamos praticamente uma repetição do quadro apresentado na ACT Alojamento. Os estados da Bahia, com 3023 empregos (6,5\%), Minas Gerais, com 2.557 empregos (5,5\%), Paraná com 2.514 empregos formais (5,4\%), Rio Grande do Sul, com 2.450 empregos (5,3\%), Santa Catarina, com 2.204 empregos (4,7\%) e Pernambuco, com 1998 (4,3\%) dos empregos formais, perfazem os oito estados mais representativos no emprego formal existente na ACT Agência de viagem.

Aos oito estados anteriormente citados devemos incluir o Distrito Federal, com 1.717 empregos (3,7\%), o único que não consta da lista dos dez maiores na ACT Alojamento e, finalmente Ceará, com 1.202 empregos (2,6\%), para compor a lista dos dez maiores geradores de empregos para a ACT Agência de Viagem. Os dez estados compõem um percentual de $86,5 \%$ dos empregos naquela ACT, enquanto que os demais estados menos representativos do emprego formal na ACT Agência de Viagem perfazem, em conjunto, apenas 13,5\% dos postos de trabalho naquela ACT, conforme demonstrado no mapa 4. 
Mapa 4. Brasil 2008: ACT Agências de Viagem - emprego formal

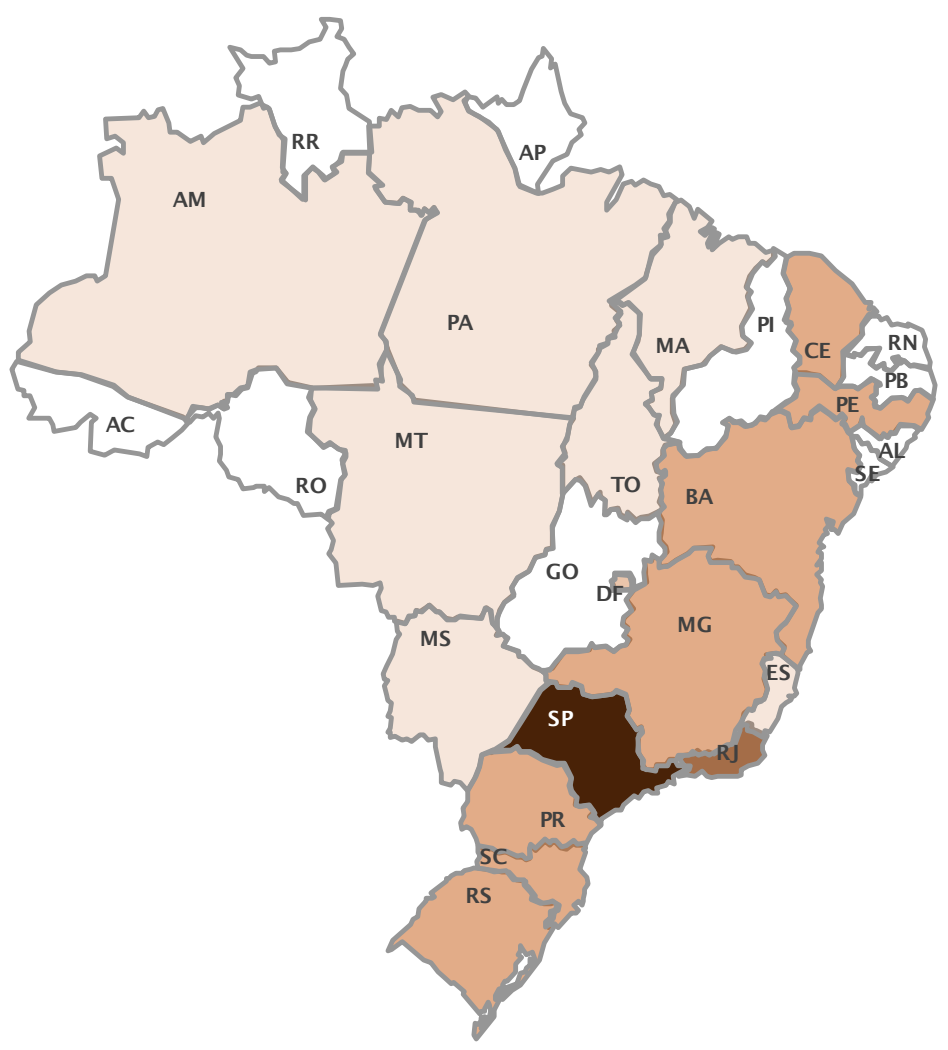

\begin{tabular}{|c|c|c|c|}
\hline & UF & DADOS & $\%$ \\
\hline 1 & SP & 16.117 & $34,6 \%$ \\
\hline 2 & RJ & 6.500 & $13,9 \%$ \\
\hline 3 & BA & 3.023 & $6,5 \%$ \\
\hline 4 & MG & 2.557 & $5,5 \%$ \\
\hline 5 & PR & 2.514 & $5,4 \%$ \\
\hline 6 & RS & 2.450 & $5,3 \%$ \\
\hline 7 & SC & 2.204 & $4,7 \%$ \\
\hline 8 & PE & 1.998 & $4,3 \%$ \\
\hline 9 & DF & 1.717 & $3,7 \%$ \\
\hline 10 & CE & 1.202 & $2,6 \%$ \\
\hline 11 & GO & 643 & $1,4 \%$ \\
\hline 12 & MA & 621 & $1,3 \%$ \\
\hline 13 & ES & 601 & $1,3 \%$ \\
\hline 14 & MT & 559 & $1,2 \%$ \\
\hline 15 & AM & 535 & $1,1 \%$ \\
\hline 16 & MS & 520 & $1,1 \%$ \\
\hline 17 & PA & 508 & $1,1 \%$ \\
\hline 18 & PI & 377 & $0,8 \%$ \\
\hline 19 & RN & 372 & $0,8 \%$ \\
\hline 20 & AL & 371 & $0,8 \%$ \\
\hline 21 & RO & 335 & $0,7 \%$ \\
\hline 22 & SE & 281 & $0,6 \%$ \\
\hline 23 & PB & 188 & $0,4 \%$ \\
\hline 24 & AC & 133 & $0,3 \%$ \\
\hline 25 & TO & 123 & $0,3 \%$ \\
\hline 26 & RR & 85 & $0,2 \%$ \\
\hline 27 & AP & 71 & $0,2 \%$ \\
\hline Brasil & 46.605 & $100 \%$ \\
\hline & & &
\end{tabular}

Fonte: IPEA, 2008. Elaborado pelo autor, 2018. 
Este resultado, em si, não surpreende uma vez confrontado com a distribuição espacial das Agências de Turismo no Brasil, segundo o mapa 5, a seguir, que traz dados sobre a distribuição espacial de Agências de Turismo no Brasil, no ano de 2014.

\section{Mapa 5. Brasil 2014: Agências de Turismo por Unidades da Federação}

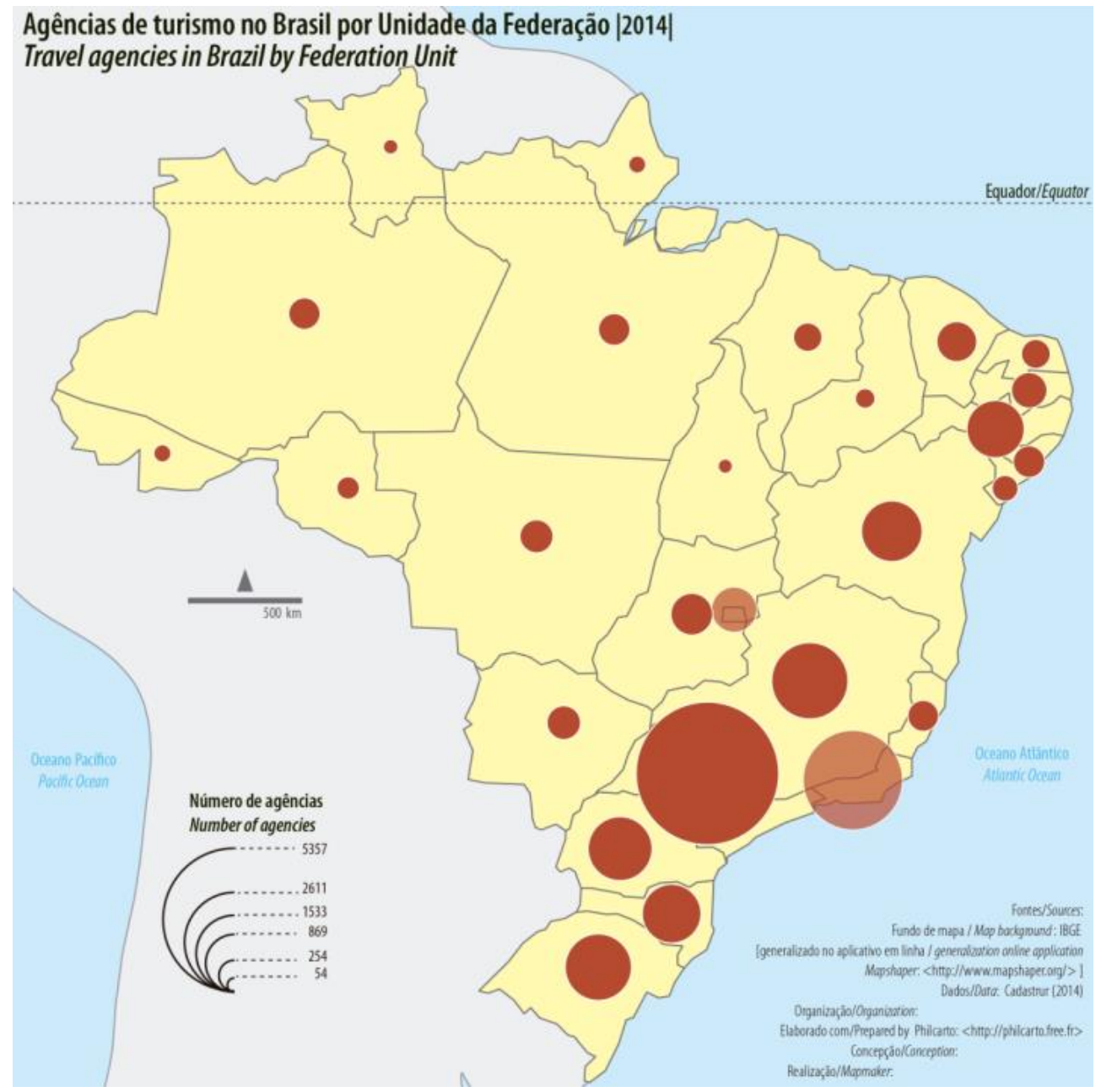

Fonte: Cadastur, 2014. Elaborado por Eduardo Dutenkefer, 2016. 
Outro importante ponto de análise refere-se à ACT Alimentação, que é a que oferece a maior quantidade de empregos no setor, embora também seja a que apresenta o maior nível de informalidade. Para exemplificar esta situação, iremos utilizar os dados de 2008, quando a ACT apresenta um total de 665.635 empregos, dos quais, apenas 184.562 eram empregos formais. Ou seja, apenas $27,7 \%$ dos empregos naquela ACT eram empregos com carteira assinada, onde reforçamos que a ACT Alimentação é a que apresenta o menor nível de formalização entre todas as demais.

\section{Mapa 6. Brasil 2008: ACT Alimentação - emprego formal}

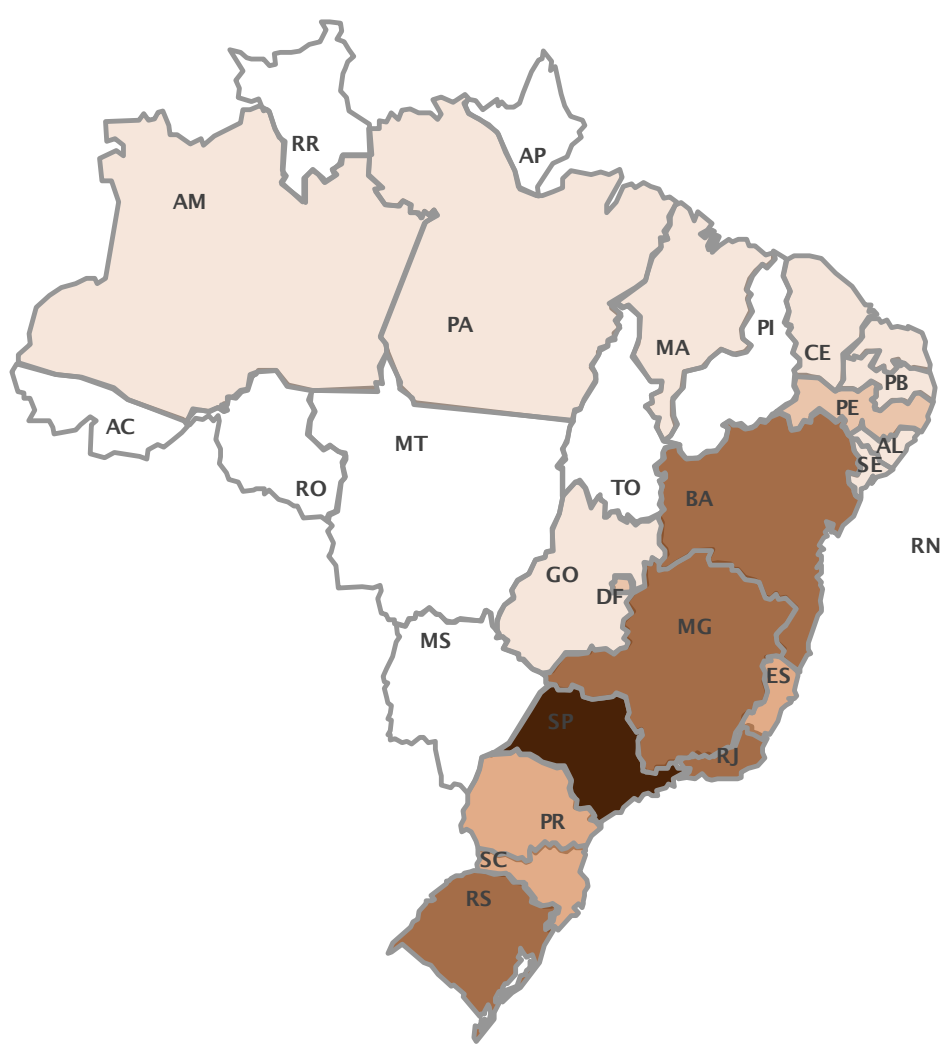

\begin{tabular}{|c|c|c|c|}
\hline & UF & DADOS & $\%$ \\
\hline 1 & SP & 44.249 & $24,0 \%$ \\
\hline 2 & MG & 34.075 & $18,5 \%$ \\
\hline 3 & $\mathrm{RJ}$ & 14.797 & $8,0 \%$ \\
\hline 4 & $\mathrm{RS}$ & 14.136 & $7,7 \%$ \\
\hline 5 & $B A$ & 11.557 & $6,3 \%$ \\
\hline 6 & SC & 8.427 & $4,6 \%$ \\
\hline 7 & ES & 8.092 & $4,4 \%$ \\
\hline 8 & PR & 7.592 & $4,1 \%$ \\
\hline 9 & $\mathrm{DF}$ & 4.776 & $2,6 \%$ \\
\hline 10 & $\mathrm{PE}$ & 4.285 & $2,3 \%$ \\
\hline 11 & $\mathrm{RN}$ & 3.548 & $1,9 \%$ \\
\hline 12 & $\mathrm{CE}$ & 2.994 & $1,6 \%$ \\
\hline 13 & MA & 2.932 & $1,6 \%$ \\
\hline 14 & PA & 2.816 & $1,5 \%$ \\
\hline 15 & GO & 2.788 & $1,5 \%$ \\
\hline 16 & $\mathrm{AL}$ & 2.741 & $1,5 \%$ \\
\hline 17 & SE & 2.305 & $1,2 \%$ \\
\hline 18 & PB & 2.265 & $1,2 \%$ \\
\hline 19 & AM & 2.053 & $1,1 \%$ \\
\hline 20 & MS & 1.922 & $1,0 \%$ \\
\hline 21 & $\mathrm{PI}$ & 1.721 & $0,9 \%$ \\
\hline 22 & MT & 1.616 & $0,9 \%$ \\
\hline 23 & RO & 1.332 & $0,7 \%$ \\
\hline 24 & $A C$ & 449 & $0,2 \%$ \\
\hline 25 & TO & 436 & $0,2 \%$ \\
\hline 26 & $\mathrm{RR}$ & 409 & $0,2 \%$ \\
\hline 27 & AP & 249 & $0,1 \%$ \\
\hline \multicolumn{2}{|c|}{ Brasil } & 184.562 & $100 \%$ \\
\hline
\end{tabular}

Fonte: IPEA, 2008. Elaborado pelo autor, 2018. 
A distribuição dos empregos nas Unidades da Federação nos permite destacar novamente a concentração do emprego nos estados das Regiões Sudeste e Sul, além de dois estados do Nordeste, Bahia e Pernambuco e o Distrito Federal.

São Paulo, com 44.249 empregos, representa 24\% dos empregos formais na referida ACT, enquanto que Minas Gerais, com 34.075, representa de forma surpreendente, 18,5\% dos empregos formais. O Rio de Janeiro, com 14.797 trabalhadores representa 8\%, enquanto que o estado da Bahia representa 7,7\% do emprego formal naquela ACT.

Santa Catarina, 4,6\%, Espirito Santo, 4,4\%, Paraná, 4,1\%, Distrito Federal, 2,6\% e Pernambuco, 2,3\%, conformam os dez estados com maior quantidade de empregos formais na ACT Alimentação.

Ainda quanto à ACT Alimentação faz-se necessário analisar o aspecto da informalidade. Com base nos dados apresentados abaixo, embora a informalidade seja alta na ACT, a mesma não se apresenta da mesma forma entre as diferentes regiões do país. Enquanto nas Regiões Norte e Nordeste o percentual de informalidade ultrapasse os $80 \%$, nas Regiões Sul e Sudeste os níveis de informalidade reduzem-se a patamares próximos de 60\%, conforme pode ser percebido pela análise do gráfico 1 . 
Gráfico 1. ACT Alimentação por regiões: emprego formal x emprego informal

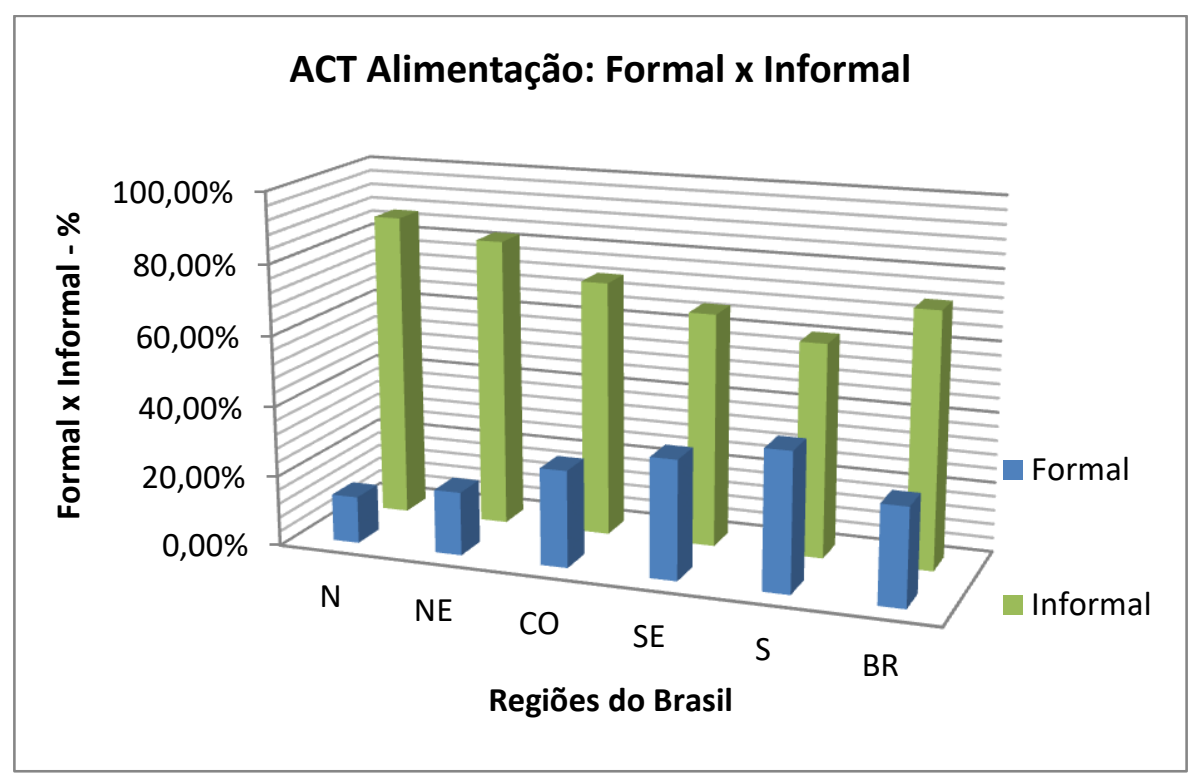

\begin{tabular}{|c|c|c|c|c|c|}
\hline Regiões & $\begin{array}{c}\text { Trabalho } \\
\text { Formal }\end{array}$ & $\mathbf{\%}$ & $\begin{array}{c}\text { Trabalho } \\
\text { Informal }\end{array}$ & $\mathbf{\%}$ & Total \\
\hline $\mathbf{N}$ & 7.744 & $13,30 \%$ & 50.461 & $86,70 \%$ & 58.205 \\
\hline NE & 34.348 & $17,97 \%$ & 156.760 & $82,03 \%$ & 191.108 \\
\hline CO & 11.102 & $27,46 \%$ & 29.329 & $72,54 \%$ & 40.431 \\
\hline SE & 101.213 & $33,81 \%$ & 198.104 & $66,19 \%$ & 299.317 \\
\hline S & 30.155 & $39,38 \%$ & 46.419 & $60,62 \%$ & 76.574 \\
\hline BR & $\mathbf{1 8 4 . 5 6 2}$ & $\mathbf{2 7 , 7 3 \%}$ & $\mathbf{4 8 1 . 0 7 3}$ & $\mathbf{7 2 , 2 7 \%}$ & $\mathbf{6 6 5 . 6 3 5}$ \\
\hline
\end{tabular}

Fonte: IPEA, 2011. Organizado pelo autor, 2018.

\section{c) Índice de Dependência do Turismo}

Outra possibilidade de análise espacial dos dados referentes ao trabalho no turismo diz respeito ao conceito de Taxa de Dependência do Turismo.

A Taxa de Dependência do Turismo - TDT é uma nova métrica proposta pelos pesquisadores irlandeses Steve Macfeely, Jillian Delaney e Fiachra O’Donoghue (2012), que procura ilustrar a oferta do turismo a partir de uma perspectiva espacial. 
Para tanto, os autores utilizam o número de estabelecimentos, o número de empregos e a massa salarial nas ACTs e comparam os dados obtidos contra os números da economia no geral (IPEA, 2015b, p.12).

Os percentuais encontrados revelam o quanto a economia no geral, depende do turismo. Cabe explicar que quanto maior o percentual encontrado, maior será a dependência da economia em relação ao turismo, enquanto atividade econômica. Por outro lado, obviamente, quanto menor o percentual, menor a dependência.

Tabela 6. Brasil 2006 - 2010 - índice de dependência do turismo (em \%)

\begin{tabular}{|l|c|c|c|c|c|}
\hline Baseado em: & $\mathbf{2 0 0 6}$ & $\mathbf{2 0 0 7}$ & $\mathbf{2 0 0 8}$ & $\mathbf{2 0 0 9}$ & $\mathbf{2 0 1 0}$ \\
\hline № estabelecimentos & 6,2 & 6,3 & 6,4 & 6,5 & 6,6 \\
\hline № empregos nas ACTs & 5,0 & 4,9 & 5,0 & 5,0 & 5,0 \\
\hline № empregos no turismo nas ACTs & 2,6 & 2,6 & 2,6 & 2,6 & 2,6 \\
\hline Massa salarial & 3,4 & 3,4 & 3,4 & 3,4 & 3,5 \\
\hline
\end{tabular}

Fonte: IPEA, 2015b. Organizado pelo autor, 2018.

Analisando os dados da tabela 6, verifica-se que, quanto ao número de estabelecimentos ocorre um pequeno, porém consistente aumento ao longo da série estudada, enquanto que, com relação ao emprego há certa estagnação, no período, sendo que o mesmo parece ocorrer com a massa salarial.

Pode-se concluir, contudo, que de acordo com a metodologia proposta, o índice de dependência do turismo no Brasil ocorre de forma mais intensa em relação aos estabelecimentos e de forma menos intensa com relação aos empregos no turismo e sobre a massa salarial.

Ainda com base nos estabelecimentos, conforme podemos observar pelo mapa 7, os estados que apresentam maior taxa de dependência do turismo encontram-se na faixa litorânea do país, sendo esta dependência ainda maior nos estados de Alagoas $(8,5 \%)$ e Rio de Janeiro $(8,0 \%)$ e, seguidos por Rio Grande do Norte $(7,7 \%)$, São Paulo $(7,1 \%)$ e Bahia $(7,1 \%)$. Distrito Federal $(9,0 \%)$ e Roraima $(8,6 \%)$ destoam desse grupo e podem estar superestimados, aparentemente por fatores diferentes. O Distrito Federal pode estar com sua importância superestimada devido o fato de que os setores públicos não foram representados na pesquisa, enquanto que Roraima possui apenas $0,15 \%$ dos estabelecimentos turísticos do Brasil (IPEA, 2015b, p. 15). 
Mapa 7. Brasil 2010: taxa de dependência do turismo baseada em número de estabelecimentos por UF (em \%)

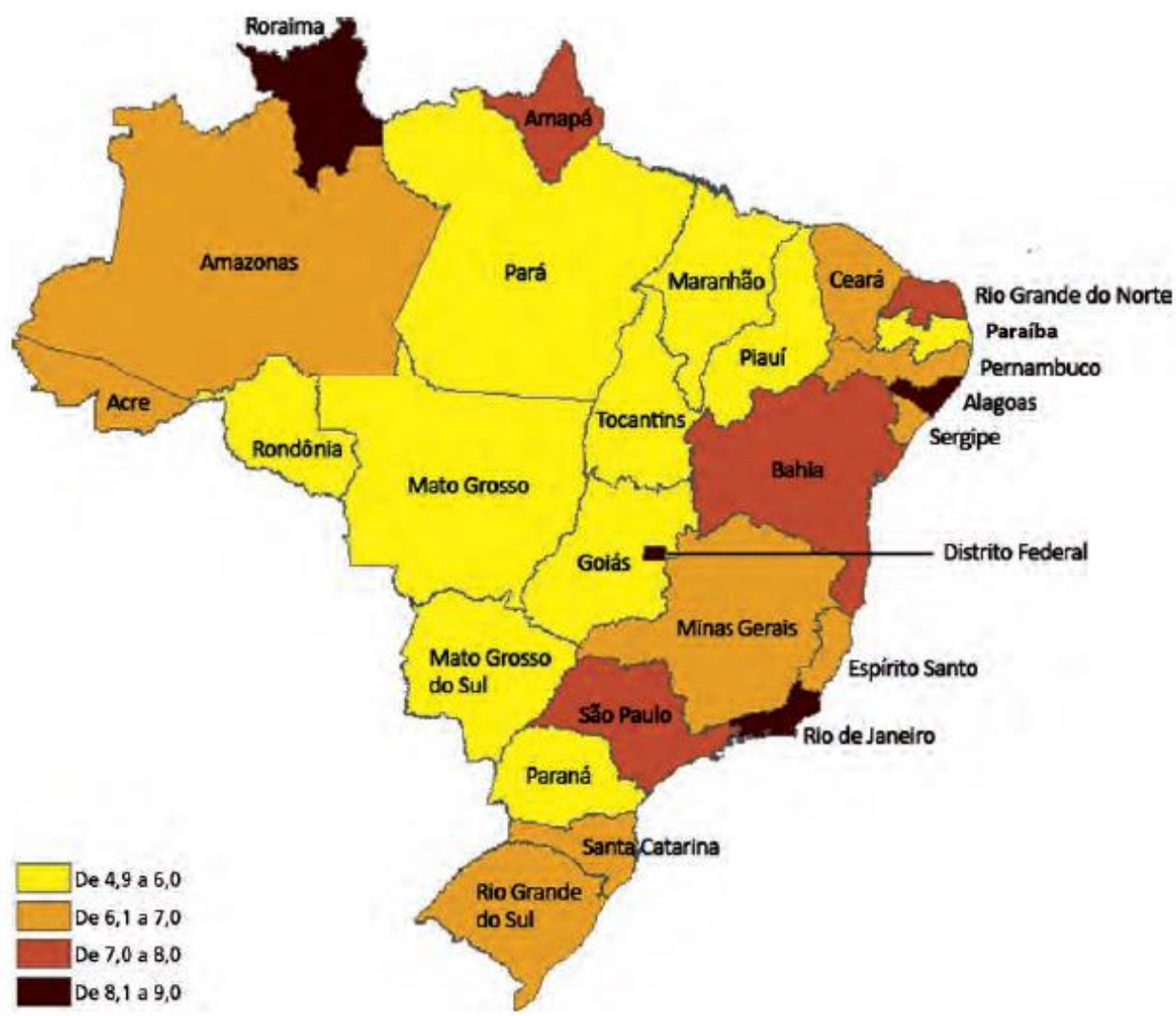

Fonte e elaboração: IPEA, 2015b. 
Este tipo de análise pode ser reveladora, pois permite identificar a importância relativa do turismo no conjunto da economia da região estudada, sem se ater somente aos números absolutos de estabelecimentos ou de pessoal empregado, por exemplo.

Esta análise também pode ser estendida ao nível regional ou mesmo local. Com base nos estabelecimentos, Fernando de Noronha, por exemplo, é o município mais dependente do turismo, sendo que $65 \%$ dos seus estabelecimentos comerciais são classificados como pertencentes ao setor turismo (IPEA, 2015b, pp. 15-18).

Outros municípios se destacam diante dos indicadores da pesquisa:

Os municípios de Cairu na Bahia (60,4\%), Jijoca de Jericoacoara no Ceará (56\%), Tibaú do Sul no Rio Grande do Norte (45,6\%), Santana do Riacho em Minas Gerais $(43,4 \%)$, Japaratinga em Alagoas (41,2\%) e Lençóis na Bahia (40,8\%) aparecem em seguida com taxas de dependência do turismo baseada em número de estabelecimentos acima de 40\% (IPEA, 2015, p.18).

O mapa 8, taxa de dependência do turismo baseado no número de empregos permite demonstrar que, novamente os estados do Rio de Janeiro (6,8\%), Rio Grande do Norte (6,7\%) e Bahia (6\%) destacam-se por apresentar valores mais altos que a média nacional (5\%), fazendo supor que, para estes estados o turismo tenha uma importância relativa maior na economia e na geração de empregos. No nível local, no entanto, a análise permite identificar índices muito maiores em algumas localidades, como é o caso do município cearense de Jijoca de Jericoacoara, com Taxa de Dependência do Turismo quanto a empregos na ordem de $71,2 \%$, enquanto que Rio Quente - GO $(63,6 \%)$ e Fernando de Noronha - PE $(61,2 \%)$ também apresentam patamares elevados para este indicador (IPEA, 2015, pp.18-20). 
Mapa 8. - Brasil 2010: taxa de dependência do turismo baseada no número de empregos por UF $($ em \%)

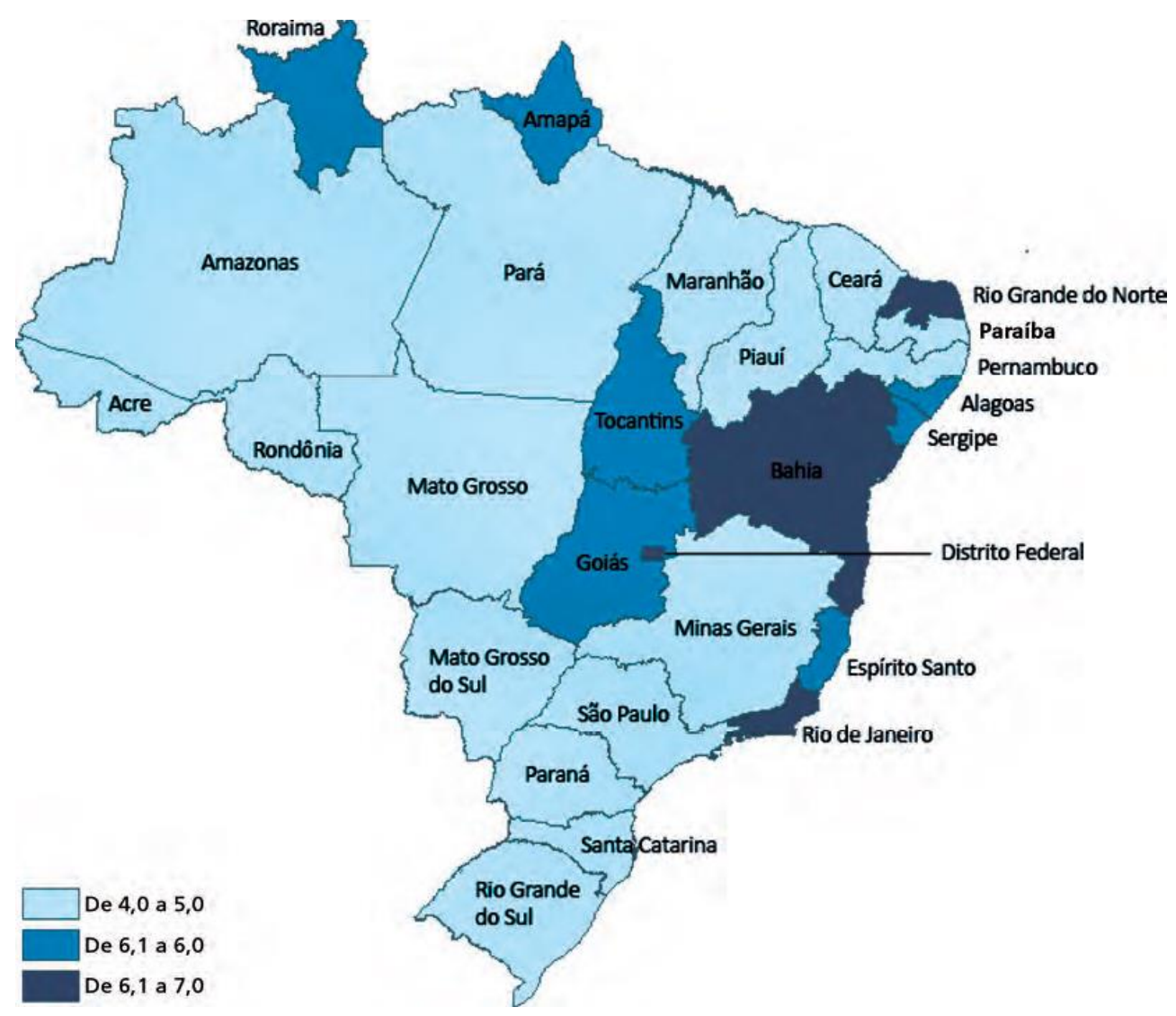

Fonte e elaboração: IPEA, 2015b. 
Os dois exemplos expostos permitem identificar, em nível local que, tanto Fernando de Noronha, quanto Jijoca do Jeriquaquara têm uma grande dependência do turismo em suas economias, tanto pela quantidade de estabelecimentos comercias, quanto na quantidade de empregos gerados.

Nossa abordagem quanto à Taxa de Dependência no Turismo tem pretensão limitada, atendo-se somente à exposição do tema e discorrendo sobre alguns números mais relevantes, deixando entrever a possibilidade de análise que a proposta metodologia possui.

Entendemos, todavia, que uma análise da Taxa de Dependência do Turismo mais acurada em localidades brasileiras ainda está por ser feita e que a mesma certamente poderá contribuir para a avaliação das características do trabalho nesses lugares.

\subsubsection{Aspectos ocupacionais}

Outro aspecto por nós estudado refere-se às questões de natureza ocupacional associadas ao trabalho no turismo. Conforme já foi dito anteriormente, não nos basta quantificar e identificar a espacialização do trabalho, mas também nos interessa identificar suas qualidades.

Para realizar esta empreitada, no entanto, discutiremos alguns dos importantes aspectos ocupacionais do trabalho no turismo, como a remuneração, a duração da jornada de trabalho, a rotatividade na função, o tamanho do estabelecimento onde o trabalho é realizado, bem como o nível de escolaridade do pessoal empregado.

A discussão sobre cada um desses pontos, bem como a análise conjunta de todos estes itens permitem extrair informações importantes sobre a qualidade do trabalho no turismo, que irá possibilitar, juntamente com as informações referentes à quantificação e espacialização, proporcionar um quadro mais completo sobre nosso objeto de estudo.

\section{a) Faixas Salariais}

Com relação aos salários no turismo, o estudo realizado pelo IPEA nos anos de 2002 a 2006 aponta que, embora o setor fosse responsável naquele momento por 2,9\% dos empregos celetistas, era responsável por apenas $2,5 \%$ do total dos salários pagos aos trabalhadores com contrato sujeito à CLT (IPEA, 2006, p. 21). 
Um dado curioso apontado pelo estudo refere-se à remuneração dos trabalhadores informais do turismo, que apresentou um percentual de 29,7\% superior aos salários correspondentes às ocupações formais, sendo que esta situação não ocorre no conjunto dos demais setores da economia.

A pesquisa aponta ainda que os rendimentos mensais médios da mão-de-obra informal, que alcançam um patamar de $\mathrm{R} \$ 839,00$, superam o rendimento dos trabalhadores formais do turismo, R\$728,00. A pesquisa indica também que há superioridade dos rendimentos nas ACTs Alojamento, Agências de Turismo e Aluguel de Transporte, onde, supostamente "os pequenos empresários podem estar obtendo grande vantagem econômica em relação aos demais trabalhadores" (IPEA, 2007, pp. 30-31).

A situação acima parece ser relevante para a análise do trabalho no setor, devido ao fato de que "há um elevado percentual de trabalhos informais do turismo realizados por empregados sem carteira de trabalho assinada", sendo que quase 35\% das 920 mil ocupações desse segmento, ou seja, 320 mil ocupações não aparecem registradas. No total dos outros setores este patamar é de $28,4 \%$ das ocupações informais, revelando um descaso da fiscalização do trabalho no setor, ressaltando que esta falta de fiscalização concentra-se no setor de Alojamento $(64,6 \%)$, Cultura e Lazer $(48,9 \%)$ e na região Centro-Oeste (40\%) (IPEA, 2007, pp. 29-30).

Dados mais recentes sobre remuneração no setor apontam que a remuneração média dos trabalhadores formais no turismo era, em dezembro de 2013 , de $\mathrm{R} \$ 1.511$, enquanto que na média da economia, R\$1.928, e do Núcleo do Turismo, R\$1.938 (IPEA, 2015, p. 17).

Entre 2006 a 2013, a remuneração média dos ocupados formais no turismo no Brasil cresceu 3,1\% ao ano (a.a.); sendo este maior que o registrado na economia como um todo, 2,4\% a.a. No Núcleo do turismo a evolução foi maior (4,0\% a.a.), conforme pode ser demonstrado na tabela 7. Por sua vez, a massa salarial gerada pelo segmento formal, corresponde a cerca de $2 \%$ da massa salarial gerada na economia formal (IPEA, 2015, p. 18). 
Tabela 7. Remuneração Média no Turismo x Remuneração média no total da economia, no período compreendido entre 2006 e 2013.

\begin{tabular}{|c|c|c|c|}
\hline $\begin{array}{c}\text { Remuneração } \\
\text { (R\$) }\end{array}$ & $\begin{array}{c}\text { Setor } \\
\text { Turismo }\end{array}$ & $\begin{array}{c}\text { Total da } \\
\text { Economia }\end{array}$ & $\begin{array}{c}\text { Núcleo do } \\
\text { Turismo }\end{array}$ \\
\hline Média Salarial & 1.511 & 1.928 & 1.938 \\
\hline Evolução Salarial & $3,1 \%$ a.a. & $2,4 \%$ a.a & $4,0 \%$ a.a \\
\hline
\end{tabular}

Fonte: IPEA, 2015. Organizado pelo autor, 2018.

Quando sobrepomos a variável remuneração sobre os números de empregos nas ACTs, podemos identificar que a ACT Alimentação, embora seja a que mais emprega, é a que apresenta menor remuneração, com uma média nacional de R \$ 844,00, para o ano de 2011.

Na outra ponta da tabela destaca-se a ACT Transporte Aéreo, com média nacional de $\mathrm{R} \$ 4.410,00$, graças à presença de uma mão-de-obra altamente qualificada.

É importante também destacar as médias salariais do setor turismo, R\$1.268,00, que apresentam valor significativamente inferior à remuneração média da economia, com $\mathrm{R} \$$ 1.606,00 e também inferior ao núcleo da ACTs, com R\$1.700,00, conforme apontado na tabela 8 .

Tabela 8. Brasil e Regiões 2011: remuneração média do empregado formal do turismo por ACT (em R\$)

\begin{tabular}{|c|c|c|c|c|c|c|c|c|c|c|c|}
\hline \multicolumn{12}{|c|}{ Remuneração média do empregado formal do turismo por ACT - Brasil e regiões ( $\mathrm{R} \$$ dez. 2011) } \\
\hline ACTs & Alojamento & Alimentação & \begin{tabular}{|c|}
$\begin{array}{c}\text { Transporte } \\
\text { terrestre }\end{array}$ \\
\end{tabular} & \begin{tabular}{|c|}
$\begin{array}{c}\text { Transporte } \\
\text { aquaviário }\end{array}$ \\
\end{tabular} & \begin{tabular}{|c|}
$\begin{array}{c}\text { Transporte } \\
\text { aéreo }\end{array}$ \\
\end{tabular} & \begin{tabular}{l|} 
Aluguel de \\
transporte
\end{tabular} & $\begin{array}{c}\text { Agência de } \\
\text { viagem }\end{array}$ & $\begin{array}{c}\text { Cultura e } \\
\text { lazer }\end{array}$ & $\begin{array}{c}\text { Núcleo das } \\
\text { ACTs }\end{array}$ & Turismo & Economia \\
\hline Brasil & 1.009 & 844 & 1.315 & 1.372 & 4.410 & 1.391 & 1.572 & 1.222 & 1.700 & 1.268 & 1.606 \\
\hline Sudeste & 1.102 & 887 & 1.356 & 2.498 & 5.070 & 1.633 & 1.827 & 1.440 & 2.231 & 1.454 & 1.812 \\
\hline Sul & 1.048 & 858 & 1.363 & 1.444 & 2.615 & 1.422 & 1.401 & 1.114 & 1.221 & 1.121 & 1.475 \\
\hline Centro-Oeste & 959 & 808 & 1.178 & 967 & 2.039 & 1.251 & 1.430 & 1.130 & 1.200 & 1.034 & 1.455 \\
\hline Norte & 829 & 753 & 1.145 & 1.292 & 2.398 & 1.273 & 992 & 834 & 1.116 & 1.004 & 1.358 \\
\hline Nordeste & 857 & 692 & 1.087 & 1.188 & 2.137 & 1.058 & 1.095 & 953 & 977 & 890 & 1.199 \\
\hline
\end{tabular}

Fonte: IPEA, 2014. Organizado pelo autor, 2018.

Analisando a questão salarial entre as ACTs, por exemplo, podemos observar grandes diferenças, a começar pela média salarial observada pela ACT Transporte aéreo, de R\$ 4.410,00, que é a maior remuneração entre todas as ACTs. Esta é seguida de longe pela ACT Agências de Viagem, R\$ 1.572,00. Lembrando que estas duas ACTs, juntamente com a ACT Alojamento, com salário médio de R \$ 1.009,00, compõem o Núcleo do Turismo. 
Na parte de baixo da tabela salarial encontraremos a ACT Alimentação, com média salarial de $\mathrm{R} \$ 844,00$, que é a ACT com maior quantidade de pessoal empregado no mercado de trabalho do turismo no Brasil.

Ainda quanto à remuneração, além de destacar as diferenças entre o turismo e a economia e suas diferenças internas, gostaríamos de destacar, neste momento, as diferenças regionais no interior do país.

Adotando a remuneração do turismo como referência ( $\mathrm{R} \$ 1.268,00)$, identificamos que, entre as regiões oficiais do IBGE, a única que apresenta média salarial superior à média nacional é a Região Sudeste, com R\$ 1.454,00. Seguida pela Região Sul, com média salarial de R \$ 1.121,00, Região Centro-Oeste, com média de R \$ 1.034,00, Região Norte, R\$ 1004,00, e em última posição, com destaque negativo, a Região Nordeste, com apenas R \$ 890,00 de média salarial para os trabalhadores formais do setor. Ou seja, a média salarial no Nordeste é 29,8\% inferior à média nacional e quase 38,8\% inferior à média da Região Sudeste, conforme salientado na tabela 9 .

Quando comparamos as médias salariais do chamado Núcleo do Turismo, novamente o Nordeste aparece como destaque negativo, pois com uma média salarial de $\mathrm{R} \$ 977,00$, a região possui um salário médio, 42,9\%, inferior à média nacional e 56,5\%, inferior à média da Região Sudeste.

Quando comparada com a economia em geral, a média salarial nordestina, de R \$ 1.199,00, mantém-se em níveis mais baixos, porém em patamares menores, que a média nacional $(25,3 \%)$ e que a média da Região Sudeste $(33,8 \%)$.

Estes dados sugerem que o turismo no Nordeste propicia ganhos salariais, em média, inferiores à média da economia como um todo. Apesar de que, como foi visto anteriormente, a Taxa de Dependência do Turismo nos estados nordestinos seja maior que nos estados do Sudeste ou do Sul.

Conforme se pode notar, a Região Nordeste apresenta uma remuneração média muito inferior a praticamente todas as demais regiões do Brasil e em praticamente todas as ACTs. As únicas exceções a essa condição ocorrem na Região Norte, que apresenta remunerações inferiores nas ACTs Alojamento, Agência de Viagem, Cultura e Lazer, enquanto que a Região Centro-Oeste apresenta salários inferiores para as ACTs Transporte Aquaviário e Transporte Aéreo. 
Tabela 9. Comparação da remuneração média: Região Nordeste x Economia - 2011 (em $\mathbf{R} \mathbf{\text { ) }}$

\begin{tabular}{|c|c|c|c|c|c|c|}
\hline $\begin{array}{c}\text { Remuneração } \\
\text { Média }\end{array}$ & \multicolumn{2}{|c|}{ Núcleo do Turismo } & \multicolumn{2}{|c|}{ Turismo } & \multicolumn{2}{c|}{ Economia } \\
\hline Nacional & 1700 & Diferença & 1268 & Diferença & 1606 & Diferença \\
\hline Nordeste & 970 & $-42,9 \%$ & 890 & $-29,8 \%$ & 1199 & $-25,3 \%$ \\
\hline $\begin{array}{c}\text { Remuneração } \\
\text { Média }\end{array}$ & Núcleo do Turismo & \multicolumn{2}{|c|}{ Turismo } & \multicolumn{2}{c|}{ Economia } \\
\hline Sudeste & 2.231 & Diferença & 1.454 & Diferença & 1.812 & Diferença \\
\hline Nordeste & 970 & $-56,5 \%$ & 890 & $-38,8 \%$ & 1199 & $-33,8 \%$ \\
\hline
\end{tabular}

Fonte: IPEA, 2014. Organizado pelo autor, 2018.

Por fim, os dados da tabela 10 apontam as médias salariais no turismo nas cinco regiões do país, segundo os dados de 2011. Por meio dos dados podemos novamente destacar a expressiva diferença entre as médias salariais identificadas, principalmente entre as Regiões Sudeste e Nordeste do país, em posições opostas na tabela.

Tabela 10 - Turismo: remuneração média por regiões - 2011

\begin{tabular}{|c|c|}
\hline Regiões & Média Salarial \\
\hline Sudeste & $1.454,00$ \\
\hline Sul & $1.121,00$ \\
\hline Centro-Oeste & $1.034,00$ \\
\hline Norte & $1.004,00$ \\
\hline Nordeste & 890,00 \\
\hline
\end{tabular}

Fonte: IPEA, 2014. Organizado pelo autor, 2018.

Os dados acima expressam as grandes diferenças regionais que têm historicamente caracterizado o território brasileiro e que se espacializam de maneira muito específica, também no trabalho no turismo, ou seja, embora a precarização no trabalho seja um fenômeno global, marcado por características gerais presentes em todos os rincões do planeta, especificidades locais e regionais não podem ser ignoradas.

Para sintetizar, podemos concluir este tópico sinalizando que, em média o salário no turismo é menor que o salário da economia como um todo e que, no chamado Núcleo Duro do turismo há uma sensível elevação salarial, que é puxado para cima em virtude dos salários da ACT Transporte Aéreo, seguido de longe pelos salários na ACT Agências de Viagem. O 
destaque salarial negativo fica por conta da ACT Alimentação que encontra-se na base da tabela, com salários muito inferiores às demais ACTs.

A questão salarial no turismo, que já apresenta médias mais baixas que a economia como um todo e em algumas ACTs, torna-se ainda mais crítica nas Regiões Norte e Nordeste do país, onde parecem ser acentuadas as condições de precarização do trabalho no setor.

\section{b) Tempo no Emprego - Rotatividade}

Outro aspecto ocupacional importante para aqueles que se dispõem a estudar as condições de trabalho refere-se à rotatividade, que reflete o tempo de permanência do trabalhador no mesmo estabelecimento.

No turismo, quando analisamos o tempo no emprego, observamos que entre as quatro faixas estabelecidas: menos 12 meses; de 12 a 23,9 meses; de 24 a 59,9 meses e; 60 meses ou mais, há maior frequência de trabalhadores com menor tempo de trabalho no mesmo emprego, embora este percentual esteja distribuído com certa uniformidade entre as faixas.

\footnotetext{
A porcentagem de ocupados com menos de doze meses no mesmo estabelecimento é maior no turismo que na economia e no Núcleo do turismo em todas as regiões, sinalizando maior rotatividade, seja por instabilidade do emprego, seja por surgirem oportunidades de trabalho mais atrativas (IPEA, 2015, p. 23).
}

O destaque positivo recai sobre o setor Transporte, onde há percentual de $36 \%$ em 2002 e de 34\% em 2006, para trabalhadores com 60 meses ou mais, demonstrando que neste setor há trabalhadores com maior tempo de casa, ou seja, com maior estabilidade.

No outro lado da tabela, ou seja, o destaque negativo, recai novamente sobre o setor Alimentação, onde os trabalhadores com menor tempo de casa (menos de 12 meses) chegam a 46\% (2002) e 47\% (2006), respectivamente. O setor Aluguel de Transporte, com 45\% (2002) e $43 \%$ (2006), respectivamente também pode ser apontado como um setor com alta rotatividade, entre os demais. Nestes setores podemos destacar uma maior rotatividade, com consequente menor estabilidade no emprego, conforme demonstrado na tabela 11. 
Tabela 11. Trabalho no turismo: rotatividade por ACT (2002 - 2006)

\begin{tabular}{|c|c|c|c|c|c|c|c|c|c|}
\hline \multirow{3}{*}{\begin{tabular}{|c|} 
ACTs \\
Alojamento
\end{tabular}} & \multirow{2}{*}{$\begin{array}{l}\text { Ano } \\
2002\end{array}$} & \multicolumn{2}{|c|}{ menos 12 meses } & \multicolumn{2}{|c|}{ 12-23,9 meses } & \multicolumn{2}{|c|}{ 24-59,9 meses } & \multicolumn{2}{|c|}{60 meses ou +} \\
\hline & & 52.755 & $36 \%$ & 28.999 & $20 \%$ & 37.360 & $25 \%$ & 29.298 & $20 \%$ \\
\hline & 2006 & 64.989 & $37 \%$ & 33.734 & $19 \%$ & 42.709 & $24 \%$ & 36.513 & $21 \%$ \\
\hline \multirow{2}{*}{ Alimentação } & 2002 & 51.815 & $46 \%$ & 22.987 & $21 \%$ & 24.756 & $22 \%$ & 12.064 & $11 \%$ \\
\hline & 2006 & 70.987 & $47 \%$ & 31.346 & $21 \%$ & 33.039 & $22 \%$ & 17.206 & $11 \%$ \\
\hline \multirow{2}{*}{ Transporte } & 2002 & 75.716 & $22 \%$ & 52.812 & $15 \%$ & 89.717 & $26 \%$ & 124.728 & $36 \%$ \\
\hline & 2006 & 85.205 & $25 \%$ & 54.685 & $16 \%$ & 88.539 & $26 \%$ & 117.237 & $34 \%$ \\
\hline \multirow{2}{*}{$\begin{array}{c}\text { Aux. } \\
\text { Transporte }\end{array}$} & 2002 & 8.626 & $33 \%$ & 4.764 & $18 \%$ & 6.212 & $24 \%$ & 6.604 & $25 \%$ \\
\hline & 2006 & 13.222 & $34 \%$ & 6.964 & $18 \%$ & 9.267 & $24 \%$ & 9.687 & $25 \%$ \\
\hline \multirow{2}{*}{$\begin{array}{l}\text { Agências de } \\
\text { Turismo }\end{array}$} & 2002 & 10.536 & $36 \%$ & 5.969 & $21 \%$ & 7.487 & $26 \%$ & 4.957 & $17 \%$ \\
\hline & 2006 & 15.045 & $39 \%$ & 8.075 & $21 \%$ & 8.933 & $23 \%$ & 7.024 & $18 \%$ \\
\hline \multirow{2}{*}{$\begin{array}{l}\text { Aluguel de } \\
\text { Transporte }\end{array}$} & 2002 & 2.889 & $43 \%$ & 1.590 & $24 \%$ & 1.528 & $23 \%$ & 752 & $11 \%$ \\
\hline & 2006 & 4.138 & $45 \%$ & 1.835 & $20 \%$ & 1.924 & $21 \%$ & 1.246 & $14 \%$ \\
\hline \multirow{2}{*}{$\begin{array}{l}\text { Cultura e } \\
\text { lazer }\end{array}$} & 2002 & 6.308 & $33 \%$ & 3.289 & $17 \%$ & 4.254 & $23 \%$ & 5.017 & $27 \%$ \\
\hline & 2006 & 6.225 & $31 \%$ & 3.304 & $17 \%$ & 4.418 & $22 \%$ & 5.912 & $30 \%$ \\
\hline \multirow{2}{*}{ Total } & 2002 & 208.644 & $31 \%$ & 120.411 & $18 \%$ & 171.315 & $25 \%$ & 183.420 & $27 \%$ \\
\hline & 2006 & 259.812 & $33 \%$ & 139.944 & $18 \%$ & 188.829 & $24 \%$ & 194.826 & $25 \%$ \\
\hline
\end{tabular}

Fonte: IPEA, 2008. Organizado pelo autor, 2018.

Quando comparamos os dados de 2006 e 2013, verifica-se o aumento da porcentagem de ocupados com menos de doze meses de trabalho, na ordem de 33,2\%, para $42 \%$. Este indicador sinaliza para um aumento da rotatividade no setor, haja vista que podemos observar uma tendência de aumento desde 2002, conforme os dados da tabela 12.

Tabela 12. Rotatividade no Turismo: proporção de empregos com menos de 12 meses

\begin{tabular}{|c|c|c|}
\hline $\mathbf{2 0 0 2}$ & $\mathbf{2 0 0 6}$ & $\mathbf{2 0 1 3}$ \\
\hline $30,5 \%$, & $33,2 \%$ & $42 \%$ \\
\hline
\end{tabular}

Fonte: IPEA, 2015. Organizado pelo autor, 2018.

A tendência do aumento da rotatividade pode ser considerada como um indicador da tendência do aumento da precarização do trabalho no setor, no qual as possibilidades de construção de uma carreira e de ascensão profissional no interior da mesma são, de modo geral, muito baixas. 


\section{c) Contrato de Trabalho - horas semanais}

Quanto à análise dos atributos ocupacionais é importante notar que quanto à jornada de trabalho o estudo aponta que $88 \%$ dos trabalhadores, equivalentes a 626,7 mil trabalhadores formais possuíam contratos de trabalho entre 41 e 44 horas semanais, em 2004, enquanto que entre os CLTs este número era de 84,3\% (IPEA, 2006, p. 29).

Conforme podemos observar na tabela 13, entre os trabalhadores no turismo há expressiva concentração de contratos de trabalho com 41 horas ou mais. Essa concentração é particularmente grande em setores como Alojamento (96,3\% - 2006), Agências de Turismo (93,4\% - 2006), Aluguel de Transporte (92,2\% - 2006) e Alimentação (91,9\% - 2006), apresentando ligeira redução percentual desta modalidade de contrato de trabalho nos setores de Transporte (83,3\% - 2006), Cultura e Lazer (80,5\% - 2006) e Auxiliar de Transporte $(76,6 \%-2006)$.

Outro fator importante para análise refere-se à "extinção de 4,8 mil contratos de trabalho no turismo de até 20 horas semanais, que afetou praticamente todos os sete grupos de ACTs", no período de 2002 a 2006, sendo que os outros contratos, com duração de 21 às 40h. e com duração de 41 ou mais, tiveram crescimentos próximos a $15,5 \%$ no período analisado (IPEA, 2008, pp.25-26).

Tabela 13. Trabalho no turismo: contrato de trabalho $x$ pessoal empregado (2002 - 2006)

\begin{tabular}{|c|c|r|r|r|r|r|r|}
\hline ACTs & Ano & \multicolumn{2}{|c|}{ até $20 \mathrm{~h}}$. & \multicolumn{2}{|c|}{$21 \mathrm{a} 40 \mathrm{~h}}$. & \multicolumn{2}{|c|}{$41 \mathrm{~h}$. ou +} \\
\hline \multirow{2}{*}{ Alojamento } & 2002 & 1.325 & $0,9 \%$ & 4.770 & $3,2 \%$ & 142.316 & $95,9 \%$ \\
\cline { 2 - 8 } & 2006 & 378 & $0,2 \%$ & 6.169 & $3,5 \%$ & 171.398 & $96,3 \%$ \\
\hline \multirow{3}{*}{ Alimentação } & 2002 & 1.649 & $1,5 \%$ & 5.348 & $4,8 \%$ & 104.625 & $93,7 \%$ \\
\cline { 2 - 8 } & 2006 & 618 & $0,4 \%$ & 11.669 & $7,6 \%$ & 140.292 & $91,9 \%$ \\
\hline \multirow{3}{*}{ Transporte } & 2002 & 3.773 & $1,1 \%$ & 54.281 & $15,8 \%$ & 284.920 & $83,1 \%$ \\
\cline { 2 - 8 } & 2006 & 2.425 & $0,7 \%$ & 55.295 & $16,0 \%$ & 287.946 & $83,3 \%$ \\
\hline \multirow{2}{*}{ Aux. Transporte } & 2002 & 1.373 & $5,2 \%$ & 6.445 & $24,6 \%$ & 18.387 & $70,2 \%$ \\
\cline { 2 - 8 } & 2006 & 43 & $0,1 \%$ & 9.104 & $23,3 \%$ & 29.994 & $76,6 \%$ \\
\hline \multirow{2}{*}{ Agências de } & 2002 & 245 & $0,8 \%$ & 2.714 & $9,4 \%$ & 25.991 & $89,8 \%$ \\
\cline { 2 - 8 } Turismo & 2006 & 99 & $0,3 \%$ & 2.467 & $6,3 \%$ & 36.511 & $93,4 \%$ \\
\hline \multirow{2}{*}{ Aluguel de } & 2002 & 19 & $0,3 \%$ & 278 & $4,1 \%$ & 6.462 & $95,6 \%$ \\
\cline { 2 - 8 } Transporte & 2006 & 17 & $0,2 \%$ & 697 & $7,6 \%$ & 8.429 & $92,2 \%$ \\
\hline \multirow{2}{*}{ Cultura e lazer } & 2002 & 723 & $3,8 \%$ & 2.662 & $14,1 \%$ & 15.484 & $82,1 \%$ \\
\cline { 2 - 8 } & 2006 & 723 & $3,6 \%$ & 3.156 & $15,9 \%$ & 15.980 & $80,5 \%$ \\
\hline \multirow{2}{*}{ Total } & 2002 & 9.106 & $1,3 \%$ & 76.499 & $11,2 \%$ & 598.185 & $87,5 \%$ \\
\cline { 2 - 8 } & 2006 & 4.304 & $0,5 \%$ & 88.557 & $11,3 \%$ & 690.550 & $88,1 \%$ \\
\hline
\end{tabular}

Fonte: IPEA, 2008. Organizado pelo autor, 2018. 
Ainda quanto à análise dos atributos demográfico-ocupacionais nos três períodos citados até aqui, há que se considerar os percentuais de horas contratuais dos trabalhadores formais no turismo. Os resultados da pesquisa em análise permitem constatar que os empregados formais no turismo trabalham mais horas que os trabalhadores da economia no geral, que era de $84 \%$ em dezembro de 2013. No mesmo ano, $89 \%$ dos empregados no turismo trabalhavam sob o regime contratual de 41 horas semanais ou mais, enquanto que, em 2002 e 2006, esse percentual era de, aproximadamente, $88 \%$ do total dos empregos do turismo (IPEA, 2015, p. 24).

\section{d) Tamanho dos Estabelecimentos}

Outro dado importante a ser levado em conta para entender o trabalho no turismo refere-se ao tamanho dos estabelecimentos. Este influencia de forma substancial a característica do emprego existente. O tamanho do estabelecimento irá influenciar muitos aspectos ocupacionais como remuneração, tempo na função, carga horária, escolaridade, entre outros.

Segundo Árias,

[...] o tamanho do estabelecimento faz-se particularmente importante sobre o aspecto remuneração, onde, em média, observa-se "1,8 SMs nas unidades de menor tamanho, até 4,7 SMs, nas de 500 ou mais empregados", enquanto que entre os trabalhadores CLT as remunerações em SMs, apresentam sensível superioridade em todas as faixas de tamanho de estabelecimento, sendo de 2,15 SMs para estabelecimentos até 9 empregados, até 5,37 SMs para empresas com mais de 500 empregados (IPEA, 2006, p. 30)

Por meio da tabela 14 podemos visualizar melhor as diferenças salariais em função das faixas de tamanho dos estabelecimentos. A pesquisa apontou um considerável aumento salarial relacionado ao maior tamanho dos estabelecimentos empregadores. 
Tabela 14. Remuneração Média (S.M.) / Tamanho dos estabelecimentos (2002 - 2006)

\begin{tabular}{|c|c|c|}
\hline Empregados & $\mathbf{2 0 0 2}$ & $\mathbf{2 0 0 6}$ \\
\hline até 09 & 1,9 & 1,6 \\
\hline $\mathbf{1 0}-\mathbf{9 9}$ & 2,7 & 2,1 \\
\hline $\mathbf{1 0 0}-\mathbf{4 9 9}$ & 3,9 & 3,1 \\
\hline $\mathbf{5 0 0}$ ou mais & 5,1 & 3,8 \\
\hline
\end{tabular}

Fonte: IPEA, 2008. Organizado pelo autor, 2018.

No turismo, como se pode observar, há predomínio dos estabelecimentos entre 10 a 99 empregados em praticamente todas as ACTs, conforme demonstrado na tabela 15.

Esta condição é alterada na ACT Transporte, onde há predomínio de empresas com 500 empregados ou mais (46\% em 2002 e 43\% em 2006), bem como grande concentração de empresas entre 100 a 499 empregados (34\%) nos anos analisados.

No lado oposto da tabela, empresas com até 9 empregados, encontramos a ACT Agências de Turismo, com percentuais de 48\% em 2002 e 44\% em 2006, demonstrando que nesta ACT há predomínio de empresas de menor porte.

Destacamos também o inexpressivo percentual de empresas com mais de 500 funcionários em empresas da ACT Alojamento, que registraram apenas 1\% em 2002 e 2\% em 2006.

Estes números refletem mais uma vez a heterogeneidade no setor turismo, expressa pela grande variedade de portes de empresa entre as diferentes ACTs. 
Tabela 15. Tamanho dos estabelecimentos por número de empregados nas ACTs (2002 2006)

\begin{tabular}{|c|c|c|c|c|c|c|c|c|c|}
\hline \multirow{3}{*}{$\begin{array}{c}\text { ACTs } \\
\text { Alojamento }\end{array}$} & \multirow{2}{*}{$\begin{array}{l}\text { Ano } \\
2002 \\
\end{array}$} & \multicolumn{2}{|c|}{ até 9 empr. } & \multicolumn{2}{|c|}{10 a 99 empr. } & \multicolumn{2}{|c|}{100 a 499 empr. } & \multicolumn{2}{|c|}{500 e mais empr. } \\
\hline & & 34.695 & $23 \%$ & 85.912 & $58 \%$ & 25.975 & $18 \%$ & 1.830 & $1 \%$ \\
\hline & 2006 & 43.316 & $24 \%$ & 102.078 & $57 \%$ & 29.552 & $17 \%$ & 3.000 & $2 \%$ \\
\hline \multirow{2}{*}{ Alimentação } & 2002 & 42.019 & $38 \%$ & 57.345 & $51 \%$ & 6.722 & $6 \%$ & 5.537 & $5 \%$ \\
\hline & 2006 & 52.840 & $35 \%$ & 81.722 & $54 \%$ & 10.230 & $7 \%$ & 7.788 & $5 \%$ \\
\hline \multirow{2}{*}{ Transporte } & 2002 & 14.753 & $4 \%$ & 54.115 & $16 \%$ & 117.122 & $34 \%$ & 156.983 & $46 \%$ \\
\hline & 2006 & 18.158 & $5 \%$ & 61.172 & $18 \%$ & 117.032 & $34 \%$ & 149.305 & $43 \%$ \\
\hline \multirow{2}{*}{$\begin{array}{c}\text { Aux. } \\
\text { Transporte }\end{array}$} & 2002 & 5.197 & $20 \%$ & 9.072 & $35 \%$ & 7.296 & $28 \%$ & 4.640 & $18 \%$ \\
\hline & 2006 & 8.109 & $21 \%$ & 14.937 & $38 \%$ & 9.938 & $25 \%$ & 6.158 & $16 \%$ \\
\hline \multirow{2}{*}{$\begin{array}{l}\text { Agências de } \\
\text { Turismo }\end{array}$} & 2002 & 13.863 & $48 \%$ & 11.798 & $41 \%$ & 2.767 & $10 \%$ & 521 & $2 \%$ \\
\hline & 2006 & 17.343 & $44 \%$ & 16.055 & $41 \%$ & 4.174 & $11 \%$ & 1.505 & $4 \%$ \\
\hline \multirow{2}{*}{$\begin{array}{l}\text { Aluguel de } \\
\text { Transporte }\end{array}$} & 2002 & 2.052 & $30 \%$ & 3.039 & $45 \%$ & 882 & $13 \%$ & 786 & $12 \%$ \\
\hline & 2006 & 2.706 & $30 \%$ & 4.060 & $44 \%$ & 1.866 & $20 \%$ & 511 & $6 \%$ \\
\hline \multirow{2}{*}{$\begin{array}{l}\text { Cultura e } \\
\text { lazer }\end{array}$} & 2002 & 5.699 & $30 \%$ & 9.094 & $48 \%$ & 3.577 & $19 \%$ & 499 & $3 \%$ \\
\hline & 2006 & 5.238 & $26 \%$ & 9.554 & $48 \%$ & 4.194 & $21 \%$ & 873 & $4 \%$ \\
\hline \multirow{2}{*}{ Total } & 2002 & 118.278 & $17 \%$ & 230.375 & $34 \%$ & 164.341 & $24 \%$ & 170.795 & $25 \%$ \\
\hline & 2006 & 147.709 & $19 \%$ & 289.578 & $37 \%$ & 176.985 & $23 \%$ & 169.139 & $22 \%$ \\
\hline
\end{tabular}

Fonte: IPEA, 2008. Organizado pelo autor, 2018.

Ainda com relação ao tamanho dos estabelecimentos, os dados mais recentemente produzidos, revelam que, no setor, a maior parte dos empregados formais trabalha em estabelecimentos que têm entre 10 e 99 empregados. No período entre 2002 e 2006 o percentual de pessoas empregadas em estabelecimentos entre 10 e 99 empregados já eram a maioria com $34 \%$ e $37 \%$, respectivamente, enquanto que, em 2013, este percentual sobe para $51 \%$, no turismo como um todo, enquanto que no contexto da economia nacional este percentual é de apenas $36 \%$, conforme demonstrado na tabela 16 .

Tabela 16. Percentual de trabalhadores em estabelecimentos com 10 a 99 empregados

\begin{tabular}{|c|c|c|}
\hline $\mathbf{2 0 0 2}$ & $\mathbf{2 0 0 6}$ & $\mathbf{2 0 1 3}$ \\
\hline $34 \%$ & $37 \%$ & $51 \%$ \\
\hline
\end{tabular}

Fonte: IPEA, 2015. Organizado pelo autor, 2018. 


\section{e) Grau de instrução / escolaridade}

Outra importante característica da força de trabalho empregada no turismo refere-se ao grau de instrução daqueles que atuam no setor. Em linhas gerais, podemos citar que o padrão educacional desta população é muito aquém do apresentado pelo conjunto dos trabalhadores celetistas.

No atributo grau de instrução, os estudos pesquisados apontam a predominância de trabalhadores com educação entre $5^{\mathrm{a}}$ e $8^{\mathrm{a}}$ série, ao passo que entre os celetistas há predomínio de trabalhadores com Ensino Médio, conforme apontam os dados da tabela 17.

Tabela 17. Grau de instrução: trabalhadores no turismo x CLT

\begin{tabular}{|c|c|c|c|c|}
\hline & $\begin{array}{c}\text { até } \\
\text { completa }\end{array}$ & $\begin{array}{c}\text { a série } \\
\text { com a } \mathbf{8}^{\mathbf{a}} \text { série } \\
\text { completa }\end{array}$ & $\begin{array}{c}\text { até } \mathbf{2}^{\mathbf{o}} \text { grau } \\
\text { completo }\end{array}$ & $\begin{array}{c}\text { Ensino } \\
\text { superior }\end{array}$ \\
\hline CLT & $15,0 \%$ & $30,4 \%$ & $41,0 \%$ & $13,6 \%$ \\
\hline Turismo & $14,9 \%$ & $40,3 \%$ & $38,2 \%$ & $6,6 \%$ \\
\hline
\end{tabular}

Fonte: IPEA, 2006. Organizado pelo autor, 2018.

Segundo Árias,

[...] esse padrão educacional, certamente compromete a qualidade dos serviços prestados aos turistas, [...] levando a crer que as menores remunerações no setor têm relação com a distribuição educacional desfavorável dos trabalhadores do turismo. [...] Esse está associado ao perfil das ocupações dominantes no turismo (IPEA, 2006, p.26).

Quanto ao padrão em questão, as ocupações que apresentam maiores frequências são: recepcionistas, camareiros, garçons, cozinheiros, motoristas, cobradores, fiscais, escriturários, caixas, bilheteiros e técnicos em turismo (IPEA, 2006, p. 33).

Um fato importante da pesquisa indica que, ao longo do período estudado, quando comparamos os dados sobre a educação no período em análise observamos uma grande elevação no patamar de anos de escolaridade para a população como um todo e, de forma consistente, em todas as ACTs.

Com base nos dados assinalados Árias aponta que, 
[...] a mudança na composição educacional do emprego formal nesse período representa o fato mais marcante acontecido recentemente no mercado de trabalho formal do turismo (IPEA, 2008, p.22).

As faixas de escolaridade adotadas: até $4^{\mathrm{a}}$ série e de $5^{\mathrm{a}}$ à $8^{\mathrm{a}}$, apresentaram sensível redução percentual, enquanto que a faixa $2^{\circ}$ grau ou mais apresentou alta substancial. Em números gerais as faixas educacionais com menos tempo de escolaridade reduziram-se de $19 \%$, em 2002, para $12 \%$, em 2006, e de $47 \%$ em 2002, para $37 \%$ em 2006, respectivamente. No mesmo período, a faixa com maior escolaridade apresentou crescimento de $38 \%$, em 2002, para 51\%, em 2006.

De acordo com as estimativas [...], o emprego no turismo, das pessoas com educação de $2^{\circ}$ grau incompleto ou superior, passou de 262,2 mil em 2002, para 398,7 mil, em 2006, ou seja, um crescimento de 136,5 mil novos postos de trabalho, valor que supera o total dos 100 mil empregos formais gerados nesse período. Na outra ponta, a dos trabalhadores com até $4^{\text {a }}$ série completa, as estimativas mostram uma diminuição de 38,4 mil empregos (IPEA, 2008, p.22).

No conjunto das ACTs, todavia, no que tange ao nível educacional dos trabalhadores, novamente encontramos diferenciações entre os setores que compõe o turismo.

Na ACT Agências de Viagem o percentual de escolaridade está entre o mais alto, dentre todas as ACTs. Em 2002, o percentual de pessoal empregado com $2^{\circ}$ grau ou mais era de $78 \%$, tendo alcançado o percentual de 86\%, em 2006.

A ACT Aluguel de Transporte ocupa a segunda posição no ranking de escolaridade do setor, com $70 \%$ de trabalhadores com $2^{\circ}$ grau ou mais de tempo nos bancos escolares.

A situação é bem diferente entre as ACTs que mais empregam no setor. De acordo com os dados do estudo em análise, para o ano de 2006, a ACT Transporte apresentava apenas $45 \%$ de trabalhadores com o $2^{\circ}$ grau ou mais, enquanto que as ACTs Alimentação e Alojamento apresentaram apenas $50 \%$ e $49 \%$ de pessoal empregado com $2^{\circ}$ grau ou mais. 
Tabela 18. Educação formal x ACTs (2002 - 2006)

\begin{tabular}{|c|c|c|c|c|c|c|c|c|}
\hline ACTs & Ano & até $4 \stackrel{a}{a}$ & & 5 a -8 a & & 20 grau & & Total \\
\hline \multirow{2}{*}{ Alojamento } & 2002 & 28.798 & $19 \%$ & 65.476 & $44 \%$ & 54.137 & $36 \%$ & 148.411 \\
\hline & 2006 & 21.979 & $12 \%$ & 69.137 & $39 \%$ & 86.829 & $49 \%$ & 177.945 \\
\hline \multirow{2}{*}{ Alimentação } & 2002 & 16.955 & $15 \%$ & 54.950 & $49 \%$ & 39.718 & $36 \%$ & 111.623 \\
\hline & 2006 & 15.186 & $10 \%$ & 61.786 & $40 \%$ & 75.606 & $50 \%$ & 152.578 \\
\hline \multirow{2}{*}{ Transporte } & 2002 & 78.939 & $23 \%$ & 147.717 & $43 \%$ & 116.317 & $34 \%$ & 342.973 \\
\hline & 2006 & 50.322 & $15 \%$ & 138.629 & $40 \%$ & 156.715 & $45 \%$ & 345.666 \\
\hline \multirow{2}{*}{$\begin{array}{c}\text { Aux. } \\
\text { Transporte }\end{array}$} & 2002 & 1.932 & $7 \%$ & 8.184 & $31 \%$ & 16.089 & $61 \%$ & 26.205 \\
\hline & 2006 & 1.946 & $5 \%$ & 9.447 & $24 \%$ & 27.748 & $71 \%$ & 39.141 \\
\hline \multirow{2}{*}{$\begin{array}{l}\text { Agências de } \\
\text { Turismo }\end{array}$} & 2002 & 1.094 & $4 \%$ & 5.280 & $18 \%$ & 22.576 & $78 \%$ & 28.950 \\
\hline & 2006 & 984 & $3 \%$ & 4.675 & $12 \%$ & 33.418 & $86 \%$ & 39.077 \\
\hline \multirow{2}{*}{$\begin{array}{l}\text { Aluguel de } \\
\text { Transporte }\end{array}$} & 2002 & 1.012 & $15 \%$ & 2.067 & $31 \%$ & 3.681 & $54 \%$ & 6.760 \\
\hline & 2006 & 474 & $5 \%$ & 2.245 & $25 \%$ & 6.424 & $70 \%$ & 9.143 \\
\hline \multirow{2}{*}{ Cultura e lazer } & 2002 & 2.973 & $16 \%$ & 6.177 & $33 \%$ & 9.718 & $52 \%$ & 18.868 \\
\hline & 2006 & 2.372 & $12 \%$ & 5.485 & $28 \%$ & 12.002 & $60 \%$ & 19.859 \\
\hline \multirow{2}{*}{ Total } & 2002 & 131.704 & $19 \%$ & 289.851 & $42 \%$ & 262.235 & $38 \%$ & 683.790 \\
\hline & 2006 & 93.263 & $12 \%$ & 291.404 & $37 \%$ & 398.744 & $51 \%$ & 783.411 \\
\hline
\end{tabular}

Fonte: IPEA, 2008. Organizado pelo autor, 2018.

Os números mais recentes sobre o assunto, no entanto, apontam que, em 2006, 47\% dos trabalhadores tinham cursado o Ensino Médio ou o Superior incompleto, enquanto que, em 2013, este número já havia saltado para 63\%, evidenciando uma melhora na escolaridade, em geral (IPEA, 2015, p.22).

Estes números apontam que, embora a baixa qualificação existente no setor, tem havido um aumento considerável no nível de escolaridade, provavelmente causada pela pressão do mercado, com vistas à melhora da qualidade dos serviços prestados ao turista. Todavia, dada a carência apresentada desde sempre pelo setor, os números gerais da escolaridade no setor ainda são baixos, com $48 \%$ dos trabalhadores com até o $5^{\circ}$ ano de estudo e apenas 8\%, com ensino superior. Nas Regiões Norte e Nordeste, onde sabidamente os indicadores apresentam maiores níveis de precariedade, os números são ainda piores. Com escolaridade até o $5^{\circ}$ ano a Região Norte apresenta $54 \%$ e a Região Nordeste $55 \%$. Com Ensino Superior as Regiões Norte e Nordeste apresentam apenas 4\% da população empregada (IPEA, 2015, p.28). 


\subsection{O trabalho no turismo sob uma perspectiva crítica}

Concordamos com a OMT quando a entidade aponta que o turismo é composto por uma ampla variedade de atividades e tipos de estabelecimentos, que promovem uma grande quantidade de contratos e acordos de trabalho produzindo um padrão de trabalho caracterizado por notável diferença entre as atividades realizadas. Estas diferenças laborais, no entanto podem se tornar ainda mais significativas, entre diferentes regiões de um mesmo país, ou até mesmo entre diferentes estações do ano.

Estes elementos, sem sombra de dúvida, caracterizam-se como aspectos que caracterizam o trabalho no turismo e apresentam dificuldades quanto ao estudo do tema.

Outros autores, no entanto, ao investigarem o tema citado também sinalizam para as dificuldades de entendimento do tema, embora ressaltando outros aspectos.

Em outra linha de investigação, que difere dos trabalhos da OMT, os pesquisadores ingleses Gareth Shaw e Allan Williams, por meio do livro: "Critical Issues in Tourism - a geographical perspective" (2002), ampliam a visão teórica sobre as características e exigências que recaem sobre a força de trabalho alocada nas atividades turísticas, a começar pelos aspectos do setor, que envolve uma variada gama de subsetores como: acomodação, alimentação, transporte, entretenimento e lazer, que sem sombra de dúvidas, dificultam a identificação e delimitação de fronteiras entre as diferentes atividades, bem como entre aquelas que atuam diretamente com turistas e as atividades que atendem tanto aos turistas, quanto a população local.

A esse respeito, no capítulo 7 da obra citada - Tourism Employment and Labor Markets -, Shaw e Williams apresentam as dificuldades inerentes à identificação e estudo da real força de trabalho alocada no turismo. Muitas estatísticas oficiais apontam os serviços de acomodação como sendo exclusivamente dedicado ao turismo, enquanto que bares, restaurantes e outros serviços, alocados em hotéis podem ser também utilizados por residentes. Quanto a isso, apontam os autores, que na ausência de estatísticas mais confiáveis, muitos pesquisadores utilizam-se de estimativas e efeitos multiplicadores. Todavia, há muitas ressalvas a serem feitas quanto ao uso de multiplicadores: $1^{\circ}$ ) requerem detalhado trabalho de pesquisa ou estimativas estatísticas sérias. Na prática, apontam Shaw e Williams, há uma tendência de haver mais utilização de multiplicadores derivados de outros, restando um pequeno número de multiplicadores baseados em dados primários; $2^{\circ}$ ) a ampla utilização de multiplicadores pode levar a erros de superestimação; $3^{\circ}$ ) os multiplicadores, na maioria dos 
casos, não levam em conta diferenças internas no setor, como por exemplo, situações onde grandes cadeias de hotéis e pequenos hotéis são tratados pelas mesmas estimativas. Os autores ainda salientam a prevalência da informalidade no turismo, tanto em lugares onde a economia não é regulamentada, ou em comunidades onde mercadorias e serviços circulam dentro de uma rede informal (SHAW; WILLIAMS, 2002, pp. 165-169).

Outro autor que centra atenção nos estudos do impacto da atividade do turismo sobre o trabalho é Dimitri Ioannides (1995).

No artigo: "Strengthening the ties between tourism and economic geography: a teoretical agenda”, o autor discorre sobre os aspectos do trabalho, destacando alguns motivos pelo baixo interesse no assunto, que conta com uma pequena produção acadêmica. Para Ioannides a ausência de foco no trabalho no turismo relaciona-se com a percepção de baixo status das atividades laborais no turismo, ressaltando que o setor exibe baixos níveis de produtividade, com baixa remuneração, necessidade de pouca habilidade no trabalho, atividades ocasionais / temporárias, sendo um trabalho realizado essencialmente por mulheres. Além desses fatores, há evidentes dificuldades na geração de dados estatísticos sobre o trabalho, realizado em diferentes equipamentos turísticos, que são utilizados tanto por turistas como por residentes locais (IOANNIDES, 1995, pp. 46-47).

No entanto, não devemos nos prender às dificuldades inerentes ao estudo do tema, nem tão pouco considerar que esta complexa organização do trabalho no turismo seja algo produzido pela atividade do turismo em si.

Antes de tudo, faz-se necessário considerar que as características das diferentes atividades que compõem o turismo são, na verdade, decorrentes dos processos que determinam seu desenvolvimento.

Ou seja, neste momento se faz necessário nos afastar dos aspectos da organização do turismo e nos voltarmos para aspectos teóricos que nos forneçam um instrumental analítico para o entendimento de sua organização.

Quanto a isso, os estudos de Stephen Grahan Britton são uma referência importante.

Em sua tese de Doutorado: "Tourism in a peripherical capitalist economy: the case of Fiji” apresentada à Australian National University (1979), o autor procura identificar os impactos do turismo em países do terceiro mundo. Nesse estudo, Britton parte das teorias do subdesenvolvimento tão debatidas na época, para analisar as relações de dominação da 
Metrópole sobre as Colônias e o papel que o turismo exerce em uma economia neocolonial, destacando a presença e o poder das empresas australianas e neozelandesas no controle da indústria do turismo, bem como demais setores da economia daquele Estado insular.

Para Britton, muitos países periféricos, na ânsia de movimentar a economia e gerar empregos, buscam a implantação de empreendimentos turísticos orientados a partir de interesses de países centrais da economia capitalista. Com a implantação desses empreendimentos turísticos, os países do terceiro mundo tornam-se cada vez mais dependentes do capital externo em múltiplos aspectos.

Um desses aspectos refere-se ao mercado de trabalho local e à geração de empregos nas indústrias do setor do turismo. Em Fiji, por exemplo, o mercado de trabalho era composto por $56,2 \%$, de uma mão de obra não assalariada, pertencente ao setor de subsistência, enquanto o setor terciário era visto como uma alternativa à geração de postos de trabalho, correspondendo a $27 \%$, da mão de obra empregada, o setor secundário empregava $12,5 \%$, e o setor primário apenas 4\% (BRITTON, 1979, p. 413).

Neste cenário, o turismo era visto como uma opção para a geração de postos de trabalho e alteração da situação do mercado de trabalho.

Para Britton, todo e qualquer investimento em turismo gera oportunidades de trabalho, embora "em geral, a literatura expressa desapontamento com a capacidade de criação de empregos no turismo", já que "a força de trabalho do turismo é representada em ocupações não qualificadas, enquanto que os expatriados são representados em posições profissionais altamente remuneradas e que o emprego tende a ser altamente sazonal" e "os funcionários na base da pirâmide da força de trabalho parecem estar sujeitos a uma exploração particularmente severa" (BRITTON, 1979, pp. 25-26).

Ainda quanto a este tema, em artigo intitulado: "The political economy of tourism in the third world" (1982), Britton aponta que um dos grandes problemas para o desenvolvimento dos estudos sobre o turismo remonta ao fato de que muitos estudos encontram-se divorciados dos processos históricos e políticos que determinam o seu desenvolvimento e que o "debate sobre as vantagens e desvantagens do turismo é conduzido sem levar em conta as teorias da política econômica relativa a persistência da pobreza e as causas da crescente desigualdade entre as nações e no interior das mesmas" (BRITTON, 1982, p. 332). 
Entendemos que este é o ponto central para o qual devemos derivar nossas reflexões, nas busca por compreender a organização socioespacial do trabalho no turismo, suas características centrais, seus resultados e quem se beneficia de tal arranjo.

No estudo citado, Britton aponta para um aspecto importante na organização do turismo em países do chamado Terceiro Mundo, em especial pequenos países insulares do oceano Pacífico, como Fiji, Tonga e Ilhas Cook, altamente impactados pela atividade turística organizada essencialmente por empresas australianas e neozelandesas.

A indústria do turismo ali instalada, portanto, reforça os mecanismos de dominação colonial e as relações metrópole - colônia, uma vez que as principais empresas que operam naqueles mercados turísticos, como: agências de viagem, companhias aéreas e cadeias de hotéis eram empresas estrangeiras, que atuam naquelas localidades associadas a certos grupos da elite local.

Os países de economia periférica, por sua vez, buscam implantar o turismo em vias de geração de divisas, aumento de oportunidades de emprego e aumento da independência econômica. No entanto, o capital externo passa a ditar todos os padrões organizacionais, de mercado, de lucratividade e de trabalho, que são regulados por empresas externas àquelas localidades acentuando a pobreza e a marginalização da população.

Este padrão de atuação da indústria do turismo pode ser entendido, deste modo, tanto do ponto de vista de uma escala local, quanto nacional e até mesmo global.

Desde o surgimento do turismo de massa, com a incorporação dos pacotes de viagem, a partir da década de 1960, a experiência turística tem sido cada vez mais padronizada, com atuação de grandes empresas que promovem integrações verticais e horizontais, para reduzir os custos das viagens, ampliando os potenciais mercados turísticos, criando novas fontes de geração de mais-valia e oferecendo a máxima oportunidade para as empresas controlarem os gastos dos turistas (BRITTON, 1982, p. 336).

O poder das grandes empresas que operam neste mercado possibilita a elas a definição dos fluxos turísticos para cada destino, por meio do controle das empresas de transporte, das cadeias de hotéis, pelas operadoras turísticas e empresas de propaganda.

As grandes empresas assumiram um papel de controle do mercado turístico mundial associando-se sempre aos governos locais, que terão um papel de estabelecer políticas que 
irão possibilitar a intermediação e o aparato legal das ações, e às elites locais, que irão comandar os circuitos locais da economia.

A união desses três atores: as grandes empresas do setor, os governos e as elites locais terão um papel preponderante no controle dos turistas e seus gastos, assim como no uso e consumo do espaço, haja vista que o turismo é uma atividade altamente dependente do espaço e, por último, no controle do trabalho e na extração da mais-valia.

Este último e decisivo aspecto, o controle do trabalho, resulta nas suas principais características, conforme vimos no item anterior: baixa qualificação, baixos salários, informalidade, concentração espacial, longas jornadas de trabalho, entre outras, caracterizando um trabalho altamente precarizado.

Sobre a precarização do trabalho no turismo, em especial, o pesquisador espanhol Ernest Cañada, professor da Universidade de Barcelona e membro do Conselho de Turismo daquela cidade é um dos pesquisadores que tem se esforçado em estudar as relações de trabalho no turismo e seus impactos, bem como as condições laborais de seus trabalhadores.

Em um de seus artigos: ¿Por qué se precariza el trabajo turístico?, Cañada aponta para "un escenario laboral dominado por la sobrecarga de trabajo, la degradación de las condiciones contractuales y un estado de inseguridad permanente." Embora esta situação seja frequentemente denunciada por sindicatos e entidades representantes dos trabalhadores, o número de turistas só faz crescer ano após ano, em diferentes cidades, mundo afora, caracterizando-se como um fenômeno mundial.

Diante de um cenário de perplexidade quanto às condições laborais produzidas no contexto turístico o autor questiona ¿A qué se debe esta precarización? Como é produzida e como explica-la?

Cañada aborda de forma mais específica o trabalho na hotelaria, por seu um setor representativo da realidade da indústria do turismo, sendo também um dos que gera mais emprego formal. Com esta delimitação básica, o autor assevera que toda empresa que opera no setor turístico, assim como os hotéis, por exemplo, busca reduzir seus custos trabalhistas na tentativa de maximizar seus lucros. Esta característica básica do capitalismo, no entanto, quando levamos em conta o cenário global atual é marcado por um enorme poder das empresas sobre o trabalho, acentuado pelo aumento da flexibilização e desregulamentação das 
leis trabalhistas, que tem reduzido o poder de organização dos trabalhadores frente às imposições do capitalismo financeiro.

A este cenário mundial de forte pressão sobre o trabalho, o autor acrescenta os efeitos econômicos restritivos ocasionados pela crise de 2008 e as importantes transformações nos ambientes organizacionais produzidos pelo desenvolvimento da tecnologia, como o uso da internet para reservas de hotéis e aquisição de demais serviços on-line, acirrando a competição entre as empresas e com isso ampliando a pressão do capital sobre o trabalho.

O próprio capitalismo financeiro, fortemente presente no setor hoteleiro, acrescenta uma maior pressão para que as empresas do setor ajustem seus custos para aumentarem o retorno sobre o capital investido.

Neste cenário propício ao capital observa-se uma forte perda da capacidade de atuação sindical, ainda mais fragilizado pelas constantes flexibilizações das leis trabalhistas impostas por governos em toda parte do mundo, que promovem a precarização cada vez maior do trabalho nos hotéis e em todas as demais empresas do setor turístico, embora não somente dele.

Ainda no que tange aos fatores essencialmente do trabalho no turismo, o autor aponta três aspectos chaves, que facilitam a precarização. São eles: "a fixação relativa em um determinado território da atividade turística, as fortes variações na demanda de trabalho associada a um mercado que sofre constantes e fortes oscilações, e a possibilidade de operar com um mercado de baixa remuneração" (CAÑADA, 2017).

Em outras palavras o autor destaca que o turismo, por ser atividade dependente do território, obriga as empresas a criarem condições operacionais e laborais que possibilitem seus ganhos e, portanto tendem a pressionar o mercado de trabalho a conviver com baixos salários, pressionando uma mão-de-obra caracterizada por uma baixa formação e qualificação, a conviver com situações de forte oscilação nas demandas e grande precarização quanto às atividades desenvolvidas.

Este complexo feixe de fatores condicionam o trabalho no turismo a uma precarização crescente, tornando evidente a proletarização da atividade laboral no setor. 


\section{II - Considerações Finais}

Em 1997, o filme "Full Monty" (exibido no Brasil com o nome "Ou tudo ou nada"), dirigido pelo cineasta britânico Peter Cattaneo, retratou as consequências do desemprego em massa em uma pequena cidade industrial no interior da Inglaterra. Os habitantes da localidade, trabalhadores industriais, em sua grande maioria, são tomados pela desesperança e desespero, ao se depararem com a situação de fechamento das fábricas da região e, consequentemente, a perda de seus empregos. Diante das incertezas, alguns amigos decidem formar um grupo de dançarinos de strip-tease, para tentar a sobrevivência na nova e grave condição econômica. Apesar da severidade da situação real, o filme que alcançou enorme sucesso de bilheteria, retrata com bom humor a crise do trabalho na Inglaterra, nos governos de Thatcher e Major, entre os anos de 1979 a 1997.

Já em 2008, outro ícone do cinema retratou o mesmo fenômeno, porém, desta vez, do outro lado do Atlântico. Trata-se do filme "Gran Torino", produzido e encenado por Clint Eastwood, que traz como pano de fundo as transformações socioeconômicas na cidade de Detroit, berço e símbolo maior da indústria automobilística dos EUA. Walt Kowalsky, o protagonista da história, é um típico cidadão estadunidense. Branco e de origem polonesa, Kowalsky lutou na Guerra da Coreia (1950-1953) e trabalhou na Ford Motor Company, por mais de vinte anos. No enredo do filme o ex-combatente e ex-operário tem que lidar com inúmeras transformações no final de sua vida, como o abandono da família, a decadência econômica da região, devido à fuga em massa das indústrias locais, e a decadência social no bairro onde vive "tomado" pela nova vizinhança, agora composta de imigrantes asiáticos, negros e latinos.

Esses dois exemplos ilustram de forma clara o fim de uma Era Industrial, que o próprio cinema já havia ajudado a construir, com outro filme icônico, "Tempos modernos", de Charles Chaplin, de 1936, onde fábricas com chaminés fumegantes e milhares de operários representavam a pungência do capitalismo industrial.

Muito embora o cinema tenha nos ajudado a compreender tais fenômenos, é nos escritos de certos autores, por meio de suas leituras de mundo, que encontramos as bases históricas e teóricas para compreender o cenário descrito muito antes. 
Toffler, em 1980, já descrevia uma civilização industrial moribunda, enquanto Masuda, no mesmo ano, e Naisbitt, em 1983, enfatizavam as transformações de uma sociedade industrial para uma sociedade da informação.

Já David Harvey, em 1989, propunha uma pesquisa sobre as origens das mudanças culturais e político-econômicas em curso, comparando as "regras básicas de acumulação capitalista" com os novos "modos mais flexíveis de acumulação do capital", dando conta de que estas transformações eram mais de "aparência superficial do que sinais do surgimento de alguma sociedade pós-capitalista ou pós-industrial inteiramente nova” (HARVEY, 2013, p. 7).

Algumas décadas antes, Hannah Arendt, em 1958, no prólogo de seu livro "A condição humana", sinalizava que o advento da automação, que já se fazia realidade àquela época, prometia que, nas próximas décadas, "esvaziaria as fábricas e libertaria a humanidade de seu fardo mais antigo e mais natural: o fardo do trabalho e a sujeição à necessidade". Para Arendt, a era moderna trouxe consigo a glorificação teórica do trabalho, e resultou na transformação efetiva de toda sociedade em uma sociedade operária e que agora, “[...] o que se nos depara, portanto, é a possibilidade de uma sociedade de trabalhadores sem trabalho, isto é, sem dúvida a única atividade que lhes resta. Certamente nada poderia ser pior" (ARENDT, 1958:1987, pp. 12-13).

Analisando as transformações em curso, Gorz (2007) afirma que a utopia industrialista desmoronou, desregulando a então dinâmica social, promovendo uma profunda crise do modelo da sociedade do trabalho e do próprio trabalho.

A esse respeito, Claus Offe (1989) reforça que, desde os anos 1970, há uma perda da centralidade do trabalho como pilar da sociedade por inúmeros fatores como: o encerramento do ciclo de expansão econômica, após o fim da Segunda Guerra Mundial; o crescimento da população mundial, que elevou a quantidade de trabalhadores disponíveis em todo mundo; bem como o avanço do progresso técnico, que tornou-se fonte imanente de desemprego.

Analisando o trabalho no início do século XXI, Harvey (2011) acrescenta que, no quadro atual, a mobilização do capital e do trabalho tem produzido uma situação muito confortável para o capital, em relação ao trabalho. Isto acontece em função da inserção da mão de obra chinesa e de outros países asiáticos, de milhares de trabalhadores da Europa Oriental, além do trabalho de imigrantes, do trabalho feminino, da precarização e muitas 
outras formas de degradação humana, que estão presentes no trabalho hoje. Há também o aumento da tecnologia e as transformações nos processos produtivos, que devolvem uma considerável massa de trabalhadores ao exército industrial de reserva. Esta condição é necessária para manter os salários baixos, pois "a escassez de trabalho significa aumento dos salários”.

Mas em meio ao desenrolar da crise do trabalho, os últimos sessenta anos também foram marcados pela forte expansão do turismo enquanto atividade econômica.

Desde os anos 1950 e 1960, graças à expansão da economia, à estabilidade do pósguerra, ao desenvolvimento dos meios de transporte e das comunicações, à popularização dos pacotes de viagem, à massificação da atividade e a atuação de grandes empresas do setor, amealhando os gastos de milhões de novos viajantes pelas centenas de destinos turísticos mundo afora, o turismo vem crescendo enquanto uma importante atividade econômica.

Dado esse expressivo crescimento do setor, nos dias atuais, empresas e entidades ocupam-se em divulgar o turismo como uma "solução eficaz para muitos dos maiores desafios do mundo, [...] para contribuir decisivamente para a criação de empregos, redução da pobreza, proteção ambiental e paz”, conforme nos quer fazer crer o discurso de Taleb Rifai, exsecretário geral da Organização Mundial do Turismo (OMT, 2015).

Mas a tentativa de conferir ao turismo a condição de solução para a crise do trabalho não se concretiza na prática, não ao menos em todos os casos, o que está comprovado pelos dados disponíveis referentes ao trabalho no turismo no Brasil. Os dados disponibilizados pelo IPEA/SIMT, no período entre 2002 a 2013, possibilitam constatar que dos 2 milhões de trabalhadores no setor, em 2013, praticamente metade da população empregada encontrava-se na informalidade, recebendo salários, em geral, abaixo do mercado, possuindo baixa formação educacional, em contratos de trabalho com mais de 41 horas semanais, concentrando-se espacialmente nos regiões mais dinâmicas do país, principalmente nos estados do Sudeste e na porção leste do Brasil, apresentando fortes diferenças nas regiões de atuação e entre as diferentes atividades características do turismo - ACTs.

Por meio das características identificadas e, de acordo com Pochmann (2012), o trabalho no turismo no Brasil pode ser inserido na "categoria analítica de working poor", com salários abaixo de 1,5 salários mínimos, com um enorme grau de informalidade, associada às extensas jornadas de trabalho, a baixa qualificação, e as enormes diferenças das condições de 
trabalho em razão das diferenças regionais do país, que apontam para a precarização do trabalho.

Para Antunes (2018), as características presentes na rápida transformação da composição da força de trabalho no Brasil e também presentes no trabalho no turismo é a expressão de uma contradição da era atual, onde o trabalho torna-se cada vez mais marcado pela informalização, ampliação dos terceirizados, pela flexibilização, trabalhadores em tempo parcial e teletrabalhadores de vários tipos, aumentando sensivelmente o universo do trabalho precarizado.

Além dos números levantados, segundo Cañada (2017), no que tange aos fatores essencialmente do trabalho no turismo, o autor aponta especificamente três aspectos, que propiciam a precarização: a fixação relativa da atividade turística a um determinado território; as fortes variações na demanda de trabalho associada a um mercado que sofre constantes e fortes oscilações; e a possibilidade de operar com um mercado de baixa remuneração.

Em outras palavras, o autor destaca que no turismo, por ser uma atividade que depende essencialmente do território, as empresas criam condições operacionais e laborais que possibilitem seus ganhos e, portanto, tendem a pressionar o mercado de trabalho a conviver com baixos salários, obrigando uma mão-de-obra caracterizada por uma baixa formação e qualificação, a conviver com situações de forte oscilação nas demandas e grande precarização quanto às atividades desenvolvidas.

Este complexo feixe de fatores condicionam o trabalho no turismo a uma precarização crescente, tornando evidente a proletarização da atividade laboral no setor.

Por tudo isso, podemos concluir dizendo que é inegável a inserção do turismo na economia atual, assim como é inegável seu potencial de geração de empregos. No entanto, é fundamental analisarmos de forma mais cuidadosa a qualidade e as características deste trabalho, para não reproduzirmos um discurso corrente, alienado e pouco crítico. Devemos antes, porém, analisar as características desses empregos para promover as discussões necessárias e uma melhor compreensão da realidade do trabalho, identificando seus verdadeiros limites e reais desafios, principalmente quando a precarização, em suas múltiplas faces, vem sendo adotada indiscriminadamente como uma saída para a atual crise do capital. 


\section{Bibliografia:}

1. ANTUNES, Ricardo. Os sentidos do trabalho: ensaios sobre a afirmação e a negação do trabalho. São Paulo, Boitempo Editorial, 1999.

2. ANTUNES, Ricardo. O caracol e sua concha: ensaio sobre a nova morfologia do trabalho. São Paulo, Boitempo, 2005.

3. ANTUNES, Ricardo. O privilégio da servidão: o novo proletariado de serviços na era digital. São Paulo, Boitempo Editorial, 2018.

4. ARBACHE, José S.. O mercado de trabalho na atividade econômica do turismo no Brasil. Brasília, Editora UnB, 2001.

5. ARENDT, Hannah. A condição humana. Tradução: Roberto Raposo, Posfácio: Celso Lafer, 10 ed., Rio de Janeiro, Forense Universitária, 2007.

6. ARRIGHI, Giovanni. Adam Smith em Pequim: origens e fundamentos do século XXI. Tradução: Beatriz Medina, São Paulo, Boitempo, 2008.

7. AUSTEN, Jane. Sanditon \& The Waltons: Austen's unfinished novels. Mineola, Dover Publications, 2007.

8. AZEVEDO, Artur. A capital federal, O badejo, A jóia, Amor por anexins. [Estabelecimento de texto: Prof. Antonio Martins de Araújo]. Rio de Janeiro: Ediouro. (Prestígio). Texto proveniente de: Biblioteca Virtual do Estudante de Língua Portuguesa A Escola do Futuro da Universidade de São Paulo. Disponível em: <http://www.dominiopublico.gov.br/download/texto/bv000041.pdf $>$ Acesso em: $15 / 02 / 2018$.

9. BACON, Francis. Essays. Project Gutenberg Etext \#575, Disponível em: <https://pt.scribd.com/document/2351328/Essays-of-Francis-Bacon-by-Bacon-Francis1561-1626> Acesso em: 01/10/2018. 
10. BARROS, Maria Paes de. No tempo de dantes. São Paulo, Paz e Terra, 1998.

11. BORRÀS, Rafael: CAÑADA, Ernest.. ¡iÉs la calidad del empleo, estúpidos! Disponível em: <http://www.albasud.org/noticia/es/993/es-la-calidad-del-empleo-estpidos > Acesso em: 10/03/2018. Alba Sud, 2017.

12. BRITTON, Stephen G.. Tourism in a peripheral capitalist economy: the case of Fiji. Tese de Doutorado pela Australiam National University, 1979.

13. BRITTON, Stephen G.. The political economy of tourism in the third world. Annals of Tourism Research, vol. 9 pp. 331-358, 1982.

14. CAÑADA, Ernest. ¿Por qué se precariza el trabajo turístico? Disponível em $<$ http://www.sinpermiso.info/textos/por-que-se-precariza-el-trabajo-turistico $>$ Acesso em: 01/12/2017. Alba Sud, 2017.

15. CORBAIN, Alan. O território do vazio: a praia e o imaginário ocidental. Tradução: Paulo Neves, São Paulo, Companhia das Letras, 1989.

16. CRUZ, Rita de Cássia Ariza da. Desenvolvimento desigual e turismo no Brasil. Confins [Online], 36, 2018. posto online no dia 02 julho 2018, consultado o 20 outubro 2018. URL: <http://journals.openedition.org/confins/13707> DOI : 10.4000/confins. 13707.

17. CRUZ, Rita de Cássia Ariza da. Geografias do turismo: de lugares a pseudo-lugares. 2. Ed. São Paulo, Roca, 2007.

18. CRUZ, Rita de Cássia Ariza da. Introdução À Geografia do turismo. 2. Ed. São Paulo, Roca, 2003.

19. DAL ROSSO, Sadi. Teoria do valor e trabalho produtivo no setor de serviços. Caderno CRH, Salvador, v. 27, n. 70, p. 75-89, Jan./Abr. 2014. 
20. DRUCKER, Peter F.. Sociedade pós-capitalista. Tradução: Nivaldo Montingelli Júnior, São Paulo, Pioneira, 1993.

21. FARIA, João Roberto. Artur Azevedo e a burleta: A Capital Federal. Revista Letras, Curitiba, UFPR, n. 94 jun./dez. 2016.

22. FRIEDMAN, Thomas L. O mundo é plano: uma breve história do século XXI. 2nd. Edição, Tradução: Cristina Serra; Sérgio Duarte; Bruno Casotti, Rio de Janeiro, Objetiva, 2005.

23. GORZ, André. Metamorfoses do trabalho: crítica à razão econômica. São Paulo, Annablume, 2003.

24. GUERNSEY FACTS AND FIGURES, 2015. Disponível em: <http://www.gov.gg/CHttpHandler.ashx?id=97608\&p=0> Acesso em: 01/12/2015.

25. HARVEY, David. Condição pós-moderna: uma pesquisa sobre as origens da mudança cultural. 24 ed., Tradução: Adail Ubirajara Sobral e Maria Stela Gonçalves, São Paulo, Edições Loyola, 2013.

26. HARVEY, David. O enigma do capital: e as crises do capitalismo. Tradução: João Alexandre Peschanski, São Paulo, Boitempo, 2011.

27. HUGO, Victor. Os trabalhadores do mar. Tradução: Machado de Assis, São Paulo, Nova Cultural, 2002.

28. INSTITUTO DE PESQUISA ECONÔMICA APLICADA - IPEA. Uma leitura da evolução recente do mercado de trabalho do setor turismo no Brasil com base nos dados da PNAD e da RAIS. Relatório: Alfonso Rodriguez Árias, Maria Alice Cunha Barbosa Roberto Aricó Zamboni, Brasília, 2003.

29. INSTITUTO DE PESQUISA ECONÔMICA APLICADA - IPEA. Proposta metodológica para a produção de indicadores correntes sobre o mercado de 
trabalho no setor turismo, por meio de fontes secundárias de cobertura nacional. Relatório: Alfonso Rodriguez Árias, Brasília, 2004.

30. INSTITUTO DE PESQUISA ECONÔMICA APLICADA - IPEA. Caracterização da mão-de-obra formal do setor turismo com estimativas baseadas nos dados da RAIS de 2004. Relatório: Alfonso Rodriguez Árias, Brasília, 2006.

31. INSTITUTO DE PESQUISA ECONÔMICA APLICADA - IPEA. Caracterização da mão-de-obra informal do setor turismo, com estimativas baseadas nos dados da PNAD de 2005. Relatório: Alfonso Rodriguez Árias, Brasília, 2007.

32. INSTITUTO DE PESQUISA ECONÔMICA APLICADA - IPEA. Evolução da remuneração da mão-de-obra formal das principais Atividades Características do Turismo, para o Brasil e estados: Janeiro de 2003 a Dezembro de 2006. Relatório: Alfonso Rodriguez Árias, Brasília, 2007b.

33. INSTITUTO DE PESQUISA ECONÔMICA APLICADA - IPEA. Estimativas anuais da mão-de-obra informal ocupada em atividades características do turismo, tendo por base os resultados da Pesquisa Nacional por Amostra de Domicílios -PNAD, no período 2002 a 2005. Relatório: Alfonso Rodriguez Árias, Brasília, 2007c.

34. INSTITUTO DE PESQUISA ECONÔMICA APLICADA - IPEA. Caracterização da ocupação formal no turismo, com base nos dados da RAIS de 2002 e 2006, e da ocupação informal no turismo, com base nos dados da PNAD de 2002 e 2006. Relatório: Alfonso Rodriguez Árias, Brasília, 2008.

35. INSTITUTO DE PESQUISA ECONÔMICA APLICADA - IPEA. Estimativas referentes à dimensão da mão-de-obra informal nas atividades características do turismo com base nos dados da PNAD 2006, para o Brasil, regiões e estados. Relatório: Alfonso Rodriguez Árias, Brasília, 2008b.

36. INSTITUTO DE PESQUISA ECONÔMICA APLICADA - IPEA. Ocupação do setor de turismo no Brasil: análise da ocupação nas principais ACTs nos estados, regiões e Brasil. Relatório: Margarida Hatem Pinto Coelho, Brasília, 2011. 
37. INSTITUTO DE PESQUISA ECONÔMICA APLICADA - IPEA. Perfil da mão de obra do turismo no Brasil nas atividades características do turismo e em ocupações. Relatório: Margarida Hatem Pinto Coelho e Patrícia A. Morita Sakowski, Brasília, 2014.

38. INSTITUTO DE PESQUISA ECONÔMICA APLICADA - IPEA. Relatório com as estimativas da caracterização da ocupação formal e informal do turismo, com base nos dados da RAIS e da PNAD 2013, para o Brasil e regiões. Relatório: Margarida Hatem Pinto Coelho e Brunno Kalyxton Sousa Ramos, Brasília, 2015.

39. INSTITUTO DE PESQUISA ECONÔMICA APLICADA - IPEA. Mensurando o emprego no setor turismo no Brasil: do nível nacional ao regional e local. Relatório: Patrícia A. Morita Sakowski, Brasília, 2015b.

40. IOANNIDES, Dimitri. Strengthening the ties between tourism and economic geography: a teoretical agenda. The professional geographer, 47:1, 49-60, 1995.

41. JINKINGS, Nise. Trabalho e resistência na "fonte misteriosa": os bancários no mundo da eletrônica e do dinheiro. Campinas, Editora da Unicamp, 2002.

42. MARX, Karl. O capital: crítica da economia política. v.1, Tradução: Rubens Enderle, São Paulo, Boitempo Editorial, 2013.

43. MASUDA, Yoneji. A sociedade da informação como sociedade pós-industrial. Tradução: Kival Chaves Weber; Angela Melim. Rio de Janeiro, Editora Rio, 1982.

44. MELIANI, Paulo, Fernando. Estrutura e distribuição espacial do trabalho formal e informal no turismo do Brasil: contributos geográficos ao planejamento turístico regional brasileiro. In: Revista Turismo e Desenvolvimento, n. 17/18, pp. 467-478, 2012.

45. MINISTÉRIO DO TURISMO. Plano Nacional do Turismo do Ministério do Turismo: mais emprego e renda para o Brasil. 2015 Disponível em: < http://www.turismo.gov.br/2015-03-09-13-54-27.html> Acesso em: 05/05/2018. 
46. MORAES, A. C. R.: COSTA, W. M.. A valorização do espaço. São Paulo, Hucitec, 1987.

47. MORAIS, Vinícius de. O operário em construção. in: 50 poemas de revolta. Vários autores, $1^{\text {a }}$ ed. pp. 62-71, 1959, São Paulo, Companhia das Letras, 2017.

48. MOREIRA, Ruy. A Geografia do espaço-mundo: conflitos e superações no espaço do capital. Rio de Janeiro, Consequência Editorial, 2016.

49. NAISBITT, John. Megatendências: as dez grandes transformações ocorrendo na sociedade. Tradução: José Eduardo Mendonça, São Paulo, Livros Abril/Círculo do Livro, 1983.

50. OFFE, Claus. Trabalho e sociedade: problemas estruturais e perspectivas para o futuro da sociedade do trabalho. Tradução: Gustavo Bayer, Rio de Janeiro, Tempo brasileiro, 1989.

51. OSTROWER, Fayga. Criatividade e processos de criação. Petrópolis, Vozes, 1987.

52. PERROTTA, Isabella. Desenhando um paraíso tropical: a construção do Rio de Janeiro como destino turístico. Tese de Doutorado em História, FGV, Rio de Janeiro, 2011.

53. POCHMANN, Marcio. Nova classe média? O trabalho na base da pirâmide social brasileira. São Paulo, Boitempo Editorial, 2012.

54. PROSERPIO, Renata. O avanço das redes hoteleiras internacionais no Brasil. São Paulo, Aleph, 2007.

55. RABAHY, W. A.. Condições e perspectivas do mercado de trabalho no setor turismo. São Paulo, FIPE, 1995. 
56. RAFFESTIN, Claude. Por uma Geografia do poder. Tradução Maria Cecília França, São Paulo, Editora Ática, 1993.

57. SANTOS, Milton. Sociedade e espaço: a formação social como teoria e como método. In: Boletim Paulista de Geografia, n. 54, São Paulo, 1977.

58. SANTOS, Milton. O papel ativo da geografia: um manifesto. In: Revista Território, Rio de Janeiro, ano V, n. 9, pp. 103-109, jul./dez., 2000.

59. SANTOS, M.: SILVEIRA, M. L.. O Brasil: território e sociedade no início do século XXI. 4 ed. Rio de Janeiro, Record, 2002.

60. SMITH, Adam. Investigação sobre a natureza e as causas da riqueza das nações. : RICARDO, Davi. Princípios de economia política e tributação. Traduções: Conceição Jardim Maria do Carmo Cary, Eduardo Lucio Nogueira, Rolf Kuntz: 2. Ed. São Paulo, Abril Cultural, 1979.

61. STATE OF GUERNSEY COMMERCE \& EMPLOYMENT DEPERTMENT. 2014 Travel Survey - RESEARCH REPORT ON Q4 2014. Disponível em: <http://www.guernseytrademedia.com/sites/default/files/master_page_related_downloads /2015/Aug/2014_exit_survey_report_q4_0.pdf> Acesso em: 01/12/2015.

62. TOFFLER, Alvin. O choque do futuro. Tradução: Marco Aurélio de Moura Matos, 2 ed. Rio de Janeiro, Artenova, 1973.

63. TOFFLER, Alvin. A terceira onda. Tradução: João Távora, 15 Ed. Rio de Janeiro, Record, 1980.

64. VISITGUERNSEY \& THE CHAMBER OF COMMERCE TOURISM \& HOSPITAlitY SUB-GROUP. Guernsey Tourism Strategic Plan 2015 - 2025. $<$ http://www.guernseytrademedia.com/sites/default/files/master_page_related_downloads /2015/Sep/vg_strategic_plan_2015_aw_web2.pdf> Acesso em: 01/12/2015. 
65. WEBER, Max. A ética protestante e o espírito do capitalismo. Tradução: José Marcos Mariani de Macedo; Revisão Técnica: Antonio Flávio Pierucci, São Paulo, Companhia das Letras, 2004.

66. WORLD TOURISM ORGANIZATION AND INTERNATIONAL LABOUR ORGANIZATION - UNWTO/ILO. Measuring Employment in the Tourism Industries - Guide with Best Practices. Madrid, 2014.

67. WORLD TOURISM ORGANIZATION. UNWTO Annual Report 2014. Madrid, 2015. 